Fernando Frachone Neves

\title{
ANÁLISE PROSPECTIVA DAS ÁREAS DE RISCO À EROSÃO NA MICROBACIA HIDROGRÁFICA DO RIO BONITO (DESCALVADO - SP), POTENCIALMENTE POLUIDORAS POR DEJETO DE GRANJAS
}

Dissertação apresentada à Escola de Engenharia de São Carlos da Universidade de São Paulo, como parte dos requisitos para obtenção do Título de Mestre em Ciências da Engenharia Ambiental.

Orientador: Prof. Dr. Silvio Crestana

São Carlos 
DEDICO,

Aos meus pais e minhas irmãs por acreditarem nas minhas escolhas e decisões.

À minha esposa, Thaísa, pelo apoio incondicional e por ter dignificado todos os momentos da minha ausência, compreendendo minha reclusão em estudo. 


\section{AGRADECIMENTOS}

Inicialmente à Deus, pelos desafios propostos nesta existência e pela oportunidade de desenvolvimento moral e intelectual.

Ao Professor Doutor Silvio Crestana, meu orientador, pelo exemplo de pesquisador que "insiste" em manter-se nas fronteiras do conhecimento, transformando pesquisa em saber. Também pelas muitas discussões e momentos de "prosa" que iniciavam nos átomos e tangenciavam os astros.

Ao Professor Doutor Fernando das Graças Braga da Silva, notável e célebre pesquisador, pela co-orientação no trabalho e pelas muitas horas de simulações e modelagem de dados, além do respeito, amizade e grandioso entusiasmo pelo trabalho de pesquisa.

Ao Professor Doutor Reinaldo Lorandi, pela disponibilidade e acolhida em várias reuniões, cedendo de maneira gentil e graciosa, mapas e dados para que esta pesquisa pudesse ser iniciada.

Aos meus colegas de grupo de pesquisa, por terem, indiretamente, influenciado na qualidade deste trabalho. Também pelos momentos de reuniões, quando as discussões foram sempre em elevado nível.

À Universidade de São Paulo, por intermédio da Escola de Engenharia de São Carlos (EESC-USP), no Centro de Recursos Hídricos e Ecologia Aplicada (CRHEA), em seu programa de pós-graduação (PPG-SEA), por ter-me recepcionado em seu quadro de pesquisadores e disponibilizado excelente aprendizado e convivência.

À EMBRAPA Instrumentação Agropecuária, pela infra-estrutura e disponibilidade para conclusão da pesquisa.

Ao CNPq, pela bolsa de fomento de pesquisa. 
"Aspiras a vencer e vencerás, mas lembra-te de que vencer sem abrir os caminhos da vitória para os outros é avançar para o tédio da inutilidade sob o frio da solidão." 
RESUMO

NEVES, F. F. (2005). Análise prospectiva das áreas de risco à erosão na microbacia hidrográfica do Rio Bonito (Descalvado - SP), potencialmente poluidoras por dejetos de granjas. Dissertação (Mestrado) - Escola de Engenharia de São Carlos, Universidade de São Paulo, São Carlos, 2005.

A incorporação de novas tecnologias na pecuária, especialmente o confinamento de animais, proporcionou notável aumento da produtividade, otimizando o uso do solo. No entanto, esta técnica tem gerado um problema crucial à sustentabilidade da atividade: o manejo dos dejetos. Estes dejetos são normalmente lançados diretamente nos mananciais, distribuídos inadequadamente no solo, como fertilizante, ou ainda utilizados como complemento alimentar para peixes, bovinos, e até mesmo para suínos, contrariando Instruções Normativas do Ministério da Agricultura Pecuária e Abastecimento (MAPA) N N . 07/04, 08/04 e 18/04, proibitivas em relação ao assunto. Quando os dejetos de animais são utilizados como fertilizantes em solos com elevado potencial à erosão, o volume de poluentes carreados e disponibilizados aos mananciais torna-se relevante, especialmente em relação aos nutrientes Nitrogênio $(\mathrm{N})$ e Fósforo $(\mathrm{P})$. De notável interesse, por ser um pólo econômico importante e de grande concentração de granjas de aves, o município de Descalvado, situado na parte central do Estado de São Paulo, é alvo deste tipo de poluição por apresentar solo com elevado potencial erosivo. Tendo como referência este problema ambiental, o estudo concentrou-se na quantificação da produção de sedimentos nas diversas áreas da microbacia do Rio Bonito, (Descalvado - SP), relacionando-as com a concentração e a distribuição local de granjas, o manejo dos dejetos e as práticas agrícolas de cada área. A partir dos resultados de simulação, com a utilização do modelo hidrossedimentológico AVSWAT em plataforma ARCVIEW 3.1, foi possível evidenciar regiões da microbacia que mantêm elevada taxa de fornecimento de nitrogênio $(\mathrm{N})$ e fósforo $(\mathrm{P})$ para os mananciais, provenientes dos dejetos 
animais, demonstrando-se coerentes com os dados de entrada de contaminação. Os resultados das simulações de erosão para os solos da microbacia do Rio Bonito também se demonstraram coerentes com a realidade brasileira, evidenciando ser o estudo de grande aplicabilidade e interesse para os gestores e tomadores de decisão da bacia hidrográfica.

Palavras chave: bacias hidrográficas, AVSWAT, transporte de sedimentos. 
ABSTRACT

NEVES, F. F. (2005). Prospective analysis of erosion risk areas of Bonito's River watershed (Descalvado - SP), potentially polluters by dejects of granges. M. Sc. Dissertation - Escola de Engenharia de São Carlos, Universidade de São Paulo, São Carlos, 2005.

The incorporation of new technologies on livestock, specially the confinement of animals, has brought considerable increase in the productivity, optimizing the use of the soil. However, this technique has been generating a crucial problem to the sustain of the activity: the management of dejects. These dejects are being commonly thrown directly into the water sources, improperly spread onto the soil, as fertilizer or, yet, used as alimentary complement for fish, bovines, and also to pigs, thwarting the Normative Instructions of Agriculture, Livestock and Supply Ministry (MAPA) Nos. 07/04, 08/04 e 18/04 MAPA. When the animal wastes are used as a fertilizer on the soil with high potential of erosion, an important charge of pollutants is then carried and made available to sources, especially in what concerns to Nitrogen $(\mathrm{N})$ and Phosphorus $(\mathrm{P})$. With an remarkable interest, because of being an important economic center and because it concentrates a great amount of chicken granges, the city of Descalvado, located in the center of the State of São Paulo (Brazil) has been a target to this type of pollution because of it's soil feature that is high potentially erosive. By this environmental problem, the research concentrates itself in the quantification of the production of sediments in the several areas of Bonito's river watershed (Descalvado - SP), relating them to the concentration and local distribution of the granges, the waste management and the agricultural practices of each areas. Starting from the simulation results, with the use of the mathematical model AVSWAT (Arc View Soil and Water Assessment Tool) in platform ARCVIEW 3.1, it was possible to evidence the critical areas in relation of pollution, mainly those ones that contributes with Phosphorous $(P)$ and Nitrogen $(\mathrm{N})$, provided by animal wastes. The results of erosion simulations for 
the soils of the Bonito's river watershed were demonstrated coherent with the Brazilian reality, evidencing to be this research of great interest for the managers and decision makers of the watershed.

Key words: watersheds, AVSWAT, sediments transport. 


\section{LISTA DE FIGURAS}

Figura 1. Produtividade média de soja (sacos/ha) em função de doses crescentes de cama de frango. Safra 2001/2002.

Figura 2. Distribuição de amônio (N-NH4+) e nitrato (N-NO3-) no perfil do solo com aplicação de 100 m3/ha de dejetos líquidos de suínos no cultivo da soja.

Figura 3. (a) impacto da gota da água contra o solo; (b) seu efeito e erosão em sulcos. 40

Figura 4. (a) erosão por remoção de massa do tipo rastejo; (b) erosão por remoção em massa quando há desprendimento de terras.

Figura 5. Diagrama dos principais componentes do ciclo hidrológico.

Figura 6. Componentes do balanço de água no solo considerando o declive do terreno.. 53

Figura 7. Fases da Pesquisa e etapas do trabalho. 60

Figura 8. Avicultura na microbacia do rio Bonito. Descalvado (SP). 66

Figura 9. Suinocultura na microbacia do rio Bonito. Descalvado (SP). 67

Figura 10. Índices pluviométricos médios do periodo de 1990 a 2002. Descalvado (SP). 68

Figura 11. Balanço hídrico mensal. Descalvado (SP) 68

Figura 12. Localização geográfica da Microbacia Hidrográfica do Rio Bonito... 73

Figura 13. Hidrografia da APA de Descalvado (SP). 75

Figura 14. Concentração de atividades na microbacia do rio Bonito. Descalvado (SP). 77

Figura 15. Evidências de erosão laminar na Microbacia Hidrográfica do Rio Bonito. 78

Figura 16. Evidências de erosão em sulcos na Microbacia Hidrográfica do Rio Bonito. 79

Figura 17. Evidência de voçoroca na Microbacia Hidrográfica do Rio Bonito. 79

Figura 18. Suscetibilidade à erosão do solo de Descalvado (SP). 80

Figura 19. Potencial de risco à erosão da microbacia do rio Bonito. 81

Figura 20. Principais componentes do balanço hídrico simulados pelo AVSWAT..... 84

Figura 21. Esquema de caminhos viáveis para o movimento da água, simulados pelo SWAT..... 84

Figura 22. Fluxograma de processamento do AVSWAT. 86

Figura 23. Hidrografia da Microbacia Hidrográfica do Rio Bonito-Descalvado (SP).

Figura 24. Uso e ocupação do solo da Microbacia Hidrográfica do Rio Bonito - Descalvado (SP). ...... 93

Figura 25. Tipos de solos da Microbacia Hidrográfica do Rio Bonito - Descalvado (SP). 94 
Fonte: Modificado de Moraes e Lorandi, 2003 94

Figura 26. Formas e processos do Nitrogênio simulados pelo SWAT na fase terrestre. 101

Figura 27. Formas e processos do Fósforo simulados pelo AVSWAT na fase terrestre. 103

Figura 30. Imagem de curvas de nível interpoladas da microbacia hidrográfica do Rio Bonito (plataforma IDRISI).

Figura 31. Modelo de elevação digital do terreno (DEM), da microbacia hidrográfica do Rio Bonito (AVSWAT).....

Figura 32. Subdivisão da MBHRB em 41 sub-bacias.

Figura 33. Localização da granjas nas sub-bacias da MBHRB. Georreferenciamento.

Figura 34. Uso do solo, em percentual, das sub-bacias que compreendem granjas.

Figura 35. Tipos de solos, em percentual, das sub-bacias que compreendem granjas.

Figura 36. Concentração de nitrogênio $(N)$ e fósforo $(P)$ em cada sub-bacia que contêm granja. 129

Figura 37. Procedimentos para geração da base de dados e simulações do modelo SWAT via SIG.

Figura 38. Mapa de erosão média (ton/ha/ano) simulada para as 41 sub-bacias da MBHRB, no período de 1993 a 2004.

Figura 39. Erosão média (ton/ha/ano) simulada para as 41 sub-bacias da MBHRB, no período de 1993 a 2004.

20. Geração de sedimentos nas sub-bacias que contêm granjas na MBHRB.

Figura 41. Aporte de nitrogênio (N) para o canal da sub-bacia correspondente em kilogramas por ano.

Figura 42. Aporte de fósforo (P) para o canal da sub-bacia correspondente em kilogramas por ano... 142

Figura 43. Correlação entre o aporte de nitrogênio (N) para o canal e a presença de vegetação na subbacia.

Figura 44. Correlação entre o aporte de fósforo $(P)$ para o canal e a presença de vegetação na subbacia.

Figura 45. Distribuição espacial da produção anual de sedimentos (ton/ha) na MBHRB para os anos de 1993 e 1994.

Figura 46. Distribuição espacial da produção anual de sedimentos (ton/ha) na MBHRB para os anos de 1995 e 1996.

Figura 47. Distribuição espacial da produção anual de sedimentos (ton/ha) na MBHRB para os anos de 1997 e 1998.

Figura 48. Distribuição espacial da produção anual de sedimentos (ton/ha) na MBHRB para os anos de 1999 e 2000. 
Figura 49. Distribuição espacial da produção anual de sedimentos (ton/ha) na MBHRB para os anos de 2001 e 2002. 197

Figura 50. Distribuição espacial da produção anual de sedimentos (ton/ha) na MBHRB para os anos de 2003 e 2004. 198

Figura 51. Distribuição espacial da produção anual de sedimentos (ton/ha) na MBHRB para os anos de 1993 a 2004. 


\section{LISTA DE TABELAS}

Tabela 1. Consumo Brasileiro de Carne de Frangos. Série Histórica (1989 - 2003). 22

Tabela 2. Animais abatidos e peso total das carcaças, segundo os meses - Brasil - $4^{\circ}$ Trimestre de 2004 . .

Tabela 3. Produção de ovos de galinha, segundo os meses - Brasil - $4^{\circ}$ Trimestre de 2004..... 23

Tabela 4. Rebanho suíno por região geográfica . .25

Tabela 5. Principais países produtores de suínos (em mil tons.) .25

Tabela 6. Produção média diária de dejetos nas diferentes fases da vida dos suínos. 28

Tabela 7. Características químicas dos dejetos de aves e suínos. 31

Tabela 8. Composição química das camas de frangos com base na matéria seca, em percentual.

Tabela 9. Caracterização das principais fontes de poluição e seus principais efeitos poluidores.

Tabela 10. Alguns modelos utilizados para simulação de processos de erosão em bacias hidrográficas.

Tabela 11. Características do produtor e condição de uso da propriedade na microbacia hidrográfica do alto rio Bonito.

Tabela 12. Número de empregados em estabelecimentos rurais de Descalvado (SP)...... 65

Tabela 13. Características da pecuária em Descalvado (SP). 65

Tabela 14. Agrotóxicos usados na região do Rio Bonito - Descalvado (SP). 77

Tabela 15. Dados gerais de entrada para utilização do modelo SWAT ... .90

Tabela 16. Médias climatológicas mensais da MBHRB no período de 1992 a 2004. .96

Tabela 17. Grupamento de solos segundo suas qualidades, características e resistência à erosão.

Tabela 18. Número da curva de escoamento superficial para usos agrícola (la=0,2.S, condição Il de umidade antecedente e condição hidrológica superficial média).

Tabela 19. Produção de dejetos por frangos de corte e aves de postura...... 106

Tabela 20. Volume de efluente produzido, de acordo com o sistema de produção e nível de diluição.

Tabela 21. Composição da cama de aviário, em porcentagem da matéria seca.. 108 
Tabela 22. Perda de nitrogênio (N) contido no resíduo, de acordo com o tipo de manejo e armazenamento.

Tabela 23. Estimativa da perda de nitrogênio $(N)$ contido no resíduo para atmosfera de acordo com o sistema de aplicação no solo.

Tabela 24. Características dos dejetos líquidos de suínos produzidos por matrizes em ciclo completo, com teor de matéria seca entre 2 e $3 \%$.

Tabela 25. Característica do efluente de suínos em função de seu teor de MS.

Tabela 26. Usos do solo da MBHRB.

Tabela 27. Tipos de solos da MBHRB.

Tabela 28. Georreferenciamento das granjas e plantel de animais.

Tabela 29. Uso do solo, em hectares, das sub-bacias que compreendem granjas

Tabela 30. Uso do solo, em percentual, das sub-bacias que compreendem granjas.

Tabela 31. Tipos de solos, em hectares, das sub-bacias que compreendem granjas.

Tabela 32. Tipos de solos, em percentual, das sub-bacias que compreendem granjas

Tabela 33. Produção de dejetos por aves e o percentual de utilização na MBHRB.

Tabela 34. Produção total de dejetos, por suínos, e o percentual de utilização na MBHRB... 125

Tabela 35. Volume de nitrogênio $(N)$ e fósforo $(P)$ gerados em função dos dejetos totais de aves. Resultado considerando dedução de (35\%) de nitrogênio (N).

Tabela 36. Volume de nitrogênio $(N)$ e fósforo $(P)$ gerados em função dos dejetos totais de suínos..

Tabela 37. Volume final de nitrogênio $(N)$ e fósforo $(P)$ gerados em função dos dejetos totais de aves. Resultado final considerando uma perda adicional de 5\% de nitrogênio (N). 127

Tabela 38. Dados de entrada mensais do módulo de fertilizantes do AVSWAT. 127

Tabela 39. Número da CN adotado para as condições da MBHRB. 132

Tabela 40. Erosão média (ton/ha/ano) simulada para as 41 sub-bacias da MBHRB, no período de 1993 a 2004 ..

Tabela 41. Média da perda de solo (ton.) simulada para cada tipo de solo da MBHRB para o período de 1993 a 2004.

Tabela 42. Tolerância de perdas por erosão para alguns solos do Estado de São Paulo. Fonte: Bertoni e Lombardi Neto (1992).

Tabela 43. Média da perda de solo (ton/ha/ano) simulada para cada uso do solo da MBHRB para o período de 1993 a 2004.

Tabela 44. Correlações entre tipos e uso dos solos, valores simulados para erosão e as ocorrências nas sub-bacias da MBHRB. 
Tabela 45. Resultados da simulação de erosão para as sub-bacias que contêm granjas, na MBHRB.

Tabela 46. Resultados médios, em kilograma, de nitrogênio $(N)$ aportado aos mananciais da MBHRB, para o período dos 12 anos de simulações.

Tabela 47. Resultados médios, em kilograma, de fósforo $(P)$ aportado aos mananciais da MBHRB, para o período dos 12 anos de simulações.

Tabela 48. Valores de entrada de nutrientes para cada HRU, nas sub-bacias que contêm granjas. 


\section{SUMÁRIO}

RESUMO

$\begin{array}{ll}\text { ABSTRACT } & 7\end{array}$

$\begin{array}{ll}\text { LISTA DE FIGURAS } & 9\end{array}$

LISTA DE TABELAS

3.1 AVicultura E SUINOCUltura No Brasil 21

3.2 DEJETO DE GRANJAS 26

3.2.1 USO DOS DEJETOS DE GRANJAS NA AGRICULTURA 30

3.2.2 USO DOS DEJETOS DE GRANJAS NA PECUÁRIA 33

3.3 PROBLEMAS SANITÁRIOS

3.3.1 “A GRIPE DO FRANGO”" (INFLUENZA AVIÁRIA) 35

3.3.2 O MAL DA "VACA-LOUCA" (ENCEFALITE ESPONGIFORME) 37

3.3.3 IMPORTÂNCIA DA DISCUSSÃO DOS PROBLEMAS SANITÁRIOS 37

3.4 EROSÃO

3.5 A BACIA HIDROGRÁFICA COMO UNIDADE DE ESTUdO

3.6 POLUIÇÃO EM BACIAS HIDROGRÁFICAS

3.7 MODELOS MATEMÁTICOS DE SIMULAÇÃO

3.8 MODELOS HIDROSSEDIMENTOLÓGICOS

4. MATERIAIS E MÉTODOS

$\begin{array}{llr}4.1 & \text { FASES DA PESQUISA } & 59\end{array}$

4.2 A ESCOLHA DA ÁREA DE ESTUDO $\quad 61$

4.3 CARACTERIZAÇÃO DA ÁREA $\quad 62$

4.3.1 O MUNICÍPIO DE DESCALVADO (SP) $\quad 62$

$\begin{array}{ll}\text { 4.3.2 SÓCIO-ECONOMIA } & 63\end{array}$

$\begin{array}{lr}4.3 .3 \text { CLIMA } & 67\end{array}$

$\begin{array}{lr}\text { 4.3.4 SOLOS } & 68\end{array}$

$\begin{array}{lr}\text { 4.3.5 GEOLOGIA } & 70\end{array}$

\begin{tabular}{lr} 
4.3.6 DADOS GEOGRÁFICOS & 73 \\
\hline
\end{tabular}

$\begin{array}{lr}\text { 4.3.7 HIDROGRAFIA } & 73\end{array}$

$\begin{array}{ll}\text { 4.3.8 VEGETAÇÃOO } & 76\end{array}$

$\begin{array}{ll}\text { 4.3.9 FAUNA } & 76\end{array}$

4.3.10 USO E OCUPAÇÃO DO SOLO $\quad 76$

$\begin{array}{ll}\text { 4.3.11 EROSÃO NA MICROBACIA } & 78\end{array}$

$\begin{array}{lr}\text { 4.4 O MODELO AVSWAT } & 81\end{array}$ 
4.4.1 GENERALIDADES

4.4.2 DADOS DE ENTRADA NO MODELO 88

4.5 MAPA DE HIDROGRAFIA, USO E COBERTURA DO SOLO E TIPOS DE SOLOS.

4.6 PARÂMetros Climatológicos 95

4.7 PARÂMETROS DE SOLO

4.8 PARÂMETROS DE COBERTURA do SOLO 98

4.9 PARÂMETROS DE FERTILIZANTES

4.10 CÁLCULO DO VOLUME DE DEJETOS

4.10.1 AVES 106

4.10.2 SUÍNOS 106

4.11 CÁlCULO DO VOLUME de NitrogêNio (N) E FóSFORO (P) 107

$\begin{array}{ll}\text { 4.11.1 AVES } & 107\end{array}$

$\begin{array}{lr}\text { 4.11.2 SUÍNOS } & 109\end{array}$

4.12 MANEJO

5. ANÁLISE E DISCUSSÃO DOS RESULTADOS

5.1.DIVISÃO DA MICROBACIA EM SUB-BACIAS E DEFINIÇÃO DAS HRUS.

$\begin{array}{ll}\text { 5.2 DISTRIBUIÇÃO DAS GRANJAS NAS SUB-BACIAS } & 117\end{array}$

5.3 VOLUME DE DEJETOS ANIMAIS NAS SUB-BACIAS QUE CONTÊM GRANJAS.

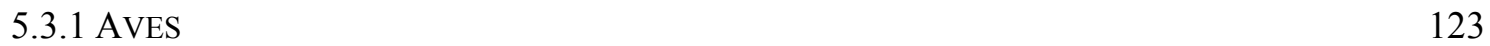

5.3.2 SUÍNOS 124

5.4 VOLUME dE NitRogênio (N) E FóSFORO (P), EM FUNÇÃo dOS DEJETOS GERADOS, NAS SUB-BACIAS QUE CONTÊM GRANJAS.

5.5 DisTRIBUIÇÃo dO NITROGÊNIO (N) E FÓSFORO (P) NAS SUB-BACIAS QUE CONTÊM

$\begin{array}{ll}\text { GRANJAS. } & 127\end{array}$

5.6 SIMULAÇÕES

5.6.1 PRODUÇÃO DE SEDIMENTOS 132

5.6.2 PRODUÇÃO DE SEDIMENTOS NAS SUB-BACIAS QUE CONTÊM GRANJAS 139

5.6.3 VOLUME DE NITROGÊNIO (N) E FÓSFORO (P) APORTADO AOS MANANCIAIS $\quad 140$

5.6.4 PRODUÇÃo BIBLIOGRÁFICA 145

5.6.4.1 Trabalhos completos em anais de eventos 146

5.6.4.2 Resumos expandidos em anais de eventos 147

$\begin{array}{ll}\text { 5.6.4.3 Capítulo de livro publicado } & 147\end{array}$

$\begin{array}{ll}\text { 5.6.4.4 Textos em jornais de notícias } & 147\end{array}$

$\begin{array}{ll}\text { 5.6.4.5 Palestra } & 148\end{array}$

$\begin{array}{ll}\text { 5.6.4.6 Trabalhos em finalização } & 148\end{array}$

6. CONCLUSÕES E RECOMENDACÕES

6.1 CONCLUSOES 149

6.2 RECOMENDACÕES

7. REFERÊNCIAS BIBLIOGRÁFICAS $\quad 153$ 


\section{INTRODUÇÃO}

Um dos maiores desafios do homem no século XXI é aumentar o conforto de vida, principalmente em decorrência do crescimento da população mundial, da escassez dos recursos naturais e da poluição.

Em especial referência ao aumento da população mundial, observa-se um fenômeno correlato importante: o crescimento da produção de bens de consumo, promovendo em vários setores da economia, ligados ao uso do solo, aumento da ocupação de terras e intensificação da produção.

Com o premente desejo de atingir a máxima produtividade, as novas tecnologias incorporadas aos setores da produção dispensaram pouca ou nenhuma atenção aos eventos negativos ao ambiente, notadamente ao solo e recursos hídricos.

A água, bem finito, é utilizada sob várias formas para atender às diferentes demandas das atividades humanas, desde as necessidades domésticas, lazer e recreação, até necessidades econômicas como irrigação, dessedentação de animais, geração de energia elétrica, navegação e recepção de efluentes.

Nas atividades econômicas rurais, o questionamento sobre a poluição dos recursos hídricos é mais complexo, uma vez que nem sempre é possível associar-se a fonte ao poluidor, caracterizando-se em difusa ou não-pontual. Fundamentalmente, este tipo de poluição é ocasionada por eventos hidrológicos importantes, associados às condições de uso e ocupação do solo e também às características pedológicas da bacia hidrográfica de observação.

Dependendo da escala de abordagem, as conseqüências da poluição oriunda das atividades rurais podem consolidar-se em alto risco à saúde 
humana. Adstrita à bacia hidrográfica, onde os eventos poluentes se originaram, a maior concentração e disponibilidade de nutrientes e outros elementos químicos podem não somente prejudicar as atividades rurais, como também prejudicar o abastecimento de água da população ribeirinha ou até mesmo de cidades próximas. Em decorrência, podem ser fonte de doenças crônicas como o câncer e outras conseqüências devido ao efeito cumulativo de alguns nutrientes, que podem originar malformações embrionárias ou mutações gênicas.

Outro fator preocupante é a presença de patógenos na água , podendo comprometer o abastecimento municipal, gerando doenças importantes do ponto de vista clínico. Segundo relatório do DEFRA (2002), são comumente associados a dejetos das atividades agrícola a Escherichia coli, Salmonella spp, Campylobacter spp e Giárdia spp. Algumas das principais infecções incluem gastroenterites, dermatites, botulismo, tétano, pneumonia, leptospirose, e disenterias provocadas por infecções intestinais.

O enfoque na prevenção à poluição em nível de microbacias é mais suscetível de resultados em face a estas serem componentes (unidades) de uma determinada bacia hidrográfica, gerando eficácia do manejo da qualidade da água (CALIJURI \& OLIVEIRA, 2000).

Neste sentido, buscando a determinação da erosão na microbacia do Rio Bonito (Descalvado - SP), bem como a quantificação de nitrogênio (N) e fósforo $(P)$ que são carreados para o corpo d'água pelos sedimentos gerados, utilizou-se o modelo hidrossedimentológico AVSWAT, tendo sido alcançados resultados de erosão coerentes com a realidade para solos brasileiros.

Com aplicação inédita na microbacia hidrográfica do Rio Bonito, o modelo AVSWAT demonstrou ser uma ferramenta complexa e de ampla abordagem, uma vez que seus módulos de processamento atingem níveis de alta especificidade. Os módulos iniciais são: uso do solo, climatologia e cobertura vegetal, seguindo-se para níveis mais específicos como fertilizantes, pesticidas, manejo e finalmente áreas urbanas. 
$\mathrm{Na}$ literatura brasileira, encontram-se disponíveis poucos trabalhos de aplicação do modelo AVSWAT em bacias hidrográficas. Que se tenha conhecimento, em todos eles apenas os módulos de uso do solo, clima e cobertura vegetal foram processados, gerando unicamente resultados de erosão na bacia hidrográfica de interesse.

Há, no entanto, o trabalho desenvolvido por Silva (2004), relativo ao PRODOC-CAPES/PPG-SEA - EESC/USP no qual estão sendo estudados limites de tolerância de perda de solo sob o ponto de vista da qualidade da água em bacias do Rio Mogi Guaçu com abordagem ambiental. Para tanto, vem se utilizando, no referido projeto, o modelo AVSWAT em todos os seus módulos, principalmente o módulo de fertilizantes e pesticidas.

No presente estudo, além dos níveis de simulação de erosão, avançouse para o nível de fertilizantes, resultando em conhecimento e discussão das áreas potencialmente poluidoras por dejetos de granjas, na Microbacia Hidrográfica do Rio Bonito. 


\section{OBJETIVOS}

O trabalho objetivou, de modo geral:

- Analisar, com o uso do AVSWAT o efeito da produção de sedimentos, em conseqüência da erosão na Microbacia Hidrográfica do Rio Bonito (Descalvado - SP), relativamente ao risco à poluição dos recursos hídricos por dejetos de granjas.

Especificamente:

- Estimar, em um trabalho inicial, a carga dos nutrientes nitrogênio $(\mathrm{N})$ e fósforo $(P)$ que é aportada aos mananciais da microbacia, carreados pelos sedimentos gerados por erosão. 


\section{REVISÃO DE LITERATURA}

\subsection{Avicultura e Suinocultura no Brasil}

A produção brasileira de carnes cresceu em taxas elevadas na década de 90. Descrevem Zilli et al (2003), que no período de janeiro de 1997 a janeiro de 2001, o setor de frangos teve um incremento de $66,13 \%$, de suínos $45,14 \%$ e a produção de leite $12,49 \%$.

O aumento da produtividade foi acompanhado por um discurso em prol do "combate à fome no mundo" (FILHO et al, 2001), sendo capitaneado por investimentos de grande monta na pesquisa agropecuária, fomentando novas tecnologias para o aumento da produtividade, resultando em maior produção de grãos, insumo vital para a avicultura e suinocultura.

A Tabela 1 demonstra que o promissor crescimento da produção de aves também foi bastante incentivado pelo consumo deste gênero, fato que contribuiu para a impulsão da atividade.

No quarto trimestre de 2004 foram abatidos 935,283 milhões de unidades de aves, representando aumentos de $11,07 \%$ sobre o quarto trimestre de 2003 e de $5,21 \%$ sobre o terceiro trimestre de 2004 .

No acumulado do ano houve o abate de 3,548 bilhões de unidades, aumento de $10,82 \%$ sobre o ano anterior. Os meses de maior abate de aves foram outubro, março e dezembro. 
Tabela 1. Consumo Brasileiro de Carne de Frangos. Série Histórica (1989 - 2003)

\begin{tabular}{|c|c|c|c|c|}
\hline \multicolumn{4}{|c|}{ Toneladas } \\
\hline Ano & Mercado Interno & $\%$ & kg/hab. & $\%$ \\
\hline 1989 & 1.811 .396 & - & 12.73 & - \\
\hline 1990 & 1.968 .069 & 8,65 & 13.60 & 6,83 \\
\hline 1991 & 2.200 .211 & 11,80 & 14.96 & 10,00 \\
\hline 1992 & 2.350 .567 & 6,83 & 15.74 & 5,21 \\
\hline 1993 & 2.709 .500 & 15,27 & 17.87 & 13,53 \\
\hline 1994 & 2.929 .997 & 8,14 & 19.06 & 6,66 \\
\hline 1995 & 3.616 .705 & 23,4 & 23.21 & 21,77 \\
\hline 1996 & 3.482 .767 & $-3,70$ & 22.05 & $-4,97$ \\
\hline 1997 & 3.811 .569 & 9,44 & 23.83 & 8,07 \\
\hline 1998 & 4.262 .231 & 11,82 & 26.31 & 10,41 \\
\hline 1999 & 4.755 .492 & 22,38 & 29.14 & 2,13 \\
\hline 2000 & 5.069 .777 & 6,61 & 29.91 & 2,64 \\
\hline 2001 & 5.486 .408 & 8,22 & 31.82 & 6,39 \\
\hline 2002 & 5.917 .000 & 7,85 & 33.81 & 9,41 \\
\hline $\mathbf{2 0 0 3}$ & 5.920 .908 & 0,07 & 33,34 & $-1,4$ \\
\hline & & & &
\end{tabular}

Fonte: ABEF - Associação Brasileira dos Produtores e Exportadores de Frangos

Os principais Estados que abateram frangos em 2004 foram: Paraná, Santa Catarina, Rio Grande do Sul, justificando a grande concentração da produção de aves na região Sul do país (Tabela 2).

As vendas externas do produto aumentaram em volume e em faturamento, relativamente ao ano de 2003. O preço da tonelada de carne de frango fechou o ano em elevação (IBGE, 2005).

A produção de ovos também tem alcançado grandes projeções. No quarto trimestre de 2004 foram produzidos 488,211 milhões de dúzias de ovos no Brasil (Tabela 3). 
Tabela 2. Animais abatidos e peso total das carcaças, segundo os meses - Brasil - $4^{\circ}$ Trimestre de 2004.

\begin{tabular}{|c|c|c|}
\hline \multirow[b]{2}{*}{ Meses } & \multicolumn{2}{|c|}{ Frangos } \\
\hline & $\begin{array}{l}\text { Num. Cabeças } \\
\text { abatidas (mil) }\end{array}$ & $\begin{array}{l}\text { Peso total das } \\
\text { carcacas }(t)\end{array}$ \\
\hline Total & 3548539 & 7059991 \\
\hline Janeiro & 283348 & 554392 \\
\hline Fevereiro & 262639 & 515060 \\
\hline Março & 307316 & 605184 \\
\hline Abril & 288230 & 573110 \\
\hline Maio & 293397 & 588841 \\
\hline Junho & 289370 & 585927 \\
\hline Julho & 299316 & 606691 \\
\hline Agosto & 295431 & 597310 \\
\hline Setembro & 294209 & 582663 \\
\hline Outubro & 308633 & 619525 \\
\hline Novembro & 304642 & 603845 \\
\hline Dezembro & 322008 & 627443 \\
\hline
\end{tabular}

Fonte - IBGE/DPE/COAGRO - Pesquisa Trimestral do Abate de Animais

Nota - 1) Os dados divulgados são oriundos de estabelecimentos que estão sob inspeção federal, estadual ou municipal.

Nota - 2) Resultados preliminares

Tabela 3. Produção de ovos de galinha, segundo os meses - Brasil - $4^{\circ}$ Trimestre de 2004

\begin{tabular}{l|c|l|c}
\hline Meses & (mil dúzias) & Meses & (mil dúzias) \\
\hline Total & 1922556 & Julho & 164166 \\
\hline Janeiro & 157150 & Agosto & 163473 \\
\hline Fevereiro & 149515 & Setembro & 161344 \\
\hline Março & 160681 & Outubro & 162129 \\
\hline Abril & 158969 & Novembro & 160554 \\
\hline Maio & 160188 & Dezembro & 165528 \\
\hline Junho & 158859 & &
\end{tabular}

Fonte - IBGE/DPE/COAGRO - Pesquisa da Produção de Ovos de Galinha Nota:

1) Resultados preliminares.

2) As informações não correspondem as produções totais das UF's uma vez que, são pesquisados apenas os estabelecimentos com 10.000 ou mais galinhas poedeiras.

3) As quantidades foram arredondadas, independentemente, para cada linha impressa e para linha de total. Em conseqüência, algumas informações registradas na linha de total não correspondem à soma exata dos valores das parcelas. 
Com isto houve aumento de 4,89\% com relação ao quarto trimestre de 2003 e queda de $0,16 \%$ sobre o terceiro trimestre de 2004 .

Em relação ao acumulado no ano de 2004, constata-se um aumento de $5,07 \%$ sobre o ano de 2003 . No ano de 2004 , o mês de maior produção de ovos de galinha foi dezembro.

Historicamente a produção de ovos é maior nos meses de maior calor. Ainda sobre o acumulado do ano, embora a Pesquisa Trimestral de Ovos de Galinha (IBGE) capte somente os estabelecimentos com 10.000 ou mais galinhas poedeiras, e tomando como base este critério metodológico, pode-se dizer que os principais Estados produtores de ovos são pela ordem: São Paulo, Minas Gerais, Paraná, Rio Grande do Sul e Santa Catarina.

No concernente à suinocultura no Brasil, caracteriza-se como uma atividade predominante de pequenas propriedades rurais, apresentando diferenças nos sistemas de produção decorrentes da coexistência de diferentes níveis tecnológicos e gerenciais (TAKITANE \& SOUZA, 2000). É uma atividade importante do ponto de vista social, econômico e, especialmente, como instrumento de fixação do homem no campo. Cerca de $81,7 \%$ dos suínos são criados em unidades de até 100 hectares. Essa atividade se encontra presente em $46,5 \%$ das 5,8 milhões de propriedades existentes no país, empregando mão-de-obra tipicamente familiar e constituindo uma importante fonte de renda e de estabilidade social (TAKITANE \& SOUZA, 2000).

A atividade encontra-se distribuída da seguinte forma nas regiões brasileiras produtoras: Sul (34,21\%), Nordeste (8,75\%), Sudeste $(7,20 \%)$, Centro-Oeste $(6,15 \%)$ e o Norte $(2,90 \%)$ (Tabela 4$)$.

Os Estados do Sul, Santa Catarina, Paraná e Rio Grande do Sul, são os maiores produtores seguidos de Minas Gerais, Bahia e São Paulo (IBGE, 2002).

A produção brasileira destaca-se entre as quatro maiores mundiais, conforme demonstrado pela Tabela 5 . 
Tabela 4. Rebanho suíno por região geográfica

\begin{tabular}{|l|c|c|l|}
\hline Regiäo & $\begin{array}{c}\mathbf{N}^{\circ} \text { Cabeças } \\
\text { (milhöes) }\end{array}$ & $\%$ & \multicolumn{1}{|c|}{ Estados } \\
\hline Sul & 13,00 & 34,21 & RS, SC, PR. \\
Sudeste & 7,20 & 18,95 & MG, ES, RJ, SP. \\
Nordeste & 8,75 & 23,03 & MA, PI, CE, RN, PB, AL, SE, BA, PE. \\
Centro Oeste & 6,15 & 16,18 & MT, MS, GO, DF. \\
Norte & 2,90 & 7,63 & RO, AC, AM, RR, PA, AP, TO. \\
\hline TOTAL & $\mathbf{3 8 , 0 0}$ & $\mathbf{1 0 0 , 0 0}$ & \\
\hline
\end{tabular}

Fonte: IBGE 2002

Tabela 5. Principais países produtores de suínos (em mil tons.)

\begin{tabular}{|l|r|r|r|r|r|r|}
\hline \multicolumn{1}{|c|}{ PAiS } & 2000 & 2001 & 2002 & 2003 & $2004^{*}$ & $2005^{+*}$ \\
\hline China & 40.314 & 41.845 & 43.266 & 45.186 & 47.170 & 47.500 \\
\hline Uniäo Européia & 20.717 & 20.427 & 20.938 & 21.243 & 21.001 & 21.108 \\
\hline Estados Unidos & 8.596 & 8.691 & 8.929 & 9.056 & 9.332 & 9.512 \\
\hline Brasil & 2.556 & 2.730 & 2.872 & 2.698 & 2.679 & 2.732 \\
\hline \hline Canadá & 1.640 & 1.731 & 1.854 & 1.882 & 1.900 & 1.935 \\
\hline Rússia & 1.500 & 1.560 & 1.630 & 1.710 & 1.740 & 1.790 \\
\hline Japão & 1.269 & 1.245 & 1.236 & 1.259 & 1.270 & 1.265 \\
\hline Filipinas & 1.008 & 1.064 & 1.095 & 1.145 & 1.175 & 1.220 \\
\hline México & 1.035 & 1.065 & 1.085 & 1.100 & 1.150 & 1.175 \\
\hline Coréia do Sul & 1.004 & 1.077 & 1.153 & 1.149 & 1.100 & 1.170 \\
\hline Taiwan & 921 & 962 & 935 & 893 & 895 & 895 \\
\hline Outros & 1.805 & 1.681 & 1.765 & 1.776 & 1.540 & 1.409 \\
\hline TOTAL & $\mathbf{8 2 . 3 6 5}$ & $\mathbf{8 4 . 0 7 8}$ & $\mathbf{8 6 . 7 5 8}$ & $\mathbf{8 9 . 0 9 7}$ & $\mathbf{9 0 . 9 5 2}$ & $\mathbf{9 1 . 7 1 1}$ \\
\hline \hline
\end{tabular}

Fonte: ABIPECS - Associação Brasileira da Indústria Produtora e Exportadora de Carne Suína.

Em faturamento, o ano de 2003 representou para os exportadores de frango um acumulado de US\$1,645 bilhão; alta de 15\% frente à receita de todo o ano de 2002.

Em 2002, o Brasil exportou 475.863 toneladas de carnes de aves, o que representou $12,2 \%$ do mercado mundial. Os principais importadores do produto 
foram a Rússia com 79,2\% dos volumes embarcados, seguido por Hong Kong $(10,5 \%)$, Argentina (2,8\%), Uruguai $(1,4 \%)$, Cingapura $(1,4 \%)$, e outros países como África do Sul, Albânia, Angola, Antilhas, Armênia, Azerbaijão, Bolívia, Bulgária, Cabo Verde, Camarões, China, Emirados Árabes, Gabão, Georgia, Granada, Haiti, Lituânia, Macedônia, Senegal, Suriname, Venezuela, Paraguai e Romênia com os $4,70 \%$ restantes.

Em relação a suínos, segundo $A B C S^{1}$, de janeiro a setembro de 2003 as vendas brasileiras somaram US\$1,36 bilhão, contra 1,0 em 2002.

No país existem atualmente cerca de 200 plantas frigoríficas que foram responsáveis pelo abate de 33,9 milhões de suínos no ano de 2004 . Na região sul a taxa de abate supera a 170 \% com média de 23 suínos / terminados / matriz / ano, que alcança a média de $110 \mathrm{~kg}$ no período de 160 dias.

Devido aos problemas sanitários com bovinos (mal da vaca-louca) nos EUA e mais recentemente com aves (gripe do frango) na Ásia, novos mercados abriram-se para o Brasil, em face aos embargos à importação de produtos dos países afetados. Somente em relação aos EUA, 30 países suspenderam a importação de carnes.

\subsection{Dejeto de Granjas}

A busca pelo aumento da produtividade tem estimulado o sistema de produção de confinamento de animais.

O caráter intensivo da produção, na busca de economias de escala e especialização, provoca uma discussão acerca da questão ambiental e a sustentabilidade da atividade, no concernente ao volume de dejetos produzidos (TAKITANE e SOUZA, 2000).

A atividade de confinamento de animais é considerada pelos órgãos ambientais uma atividade potencialmente causadora de degradação ambiental,

\footnotetext{
${ }^{1}$ ABCS - Associação Brasileira de Criadores de Suínos. http://www.abcs.com.br/
} 
sendo enquadrada como de grande potencial poluidor. Pela Legislação Ambiental (Lei 9.605/98 - Lei de Crimes Ambientais), o produtor pode ser responsabilizado criminalmente por eventuais danos causados ao meio ambiente e à saúde dos homens e animais, além das outras responsabilidades nas esferas Civil e Administrativa. Ademais, a atividade deve ser licenciada conforme determinações do CONAMA $01 / 86^{2}$ em conexão com CONAMA $237 / 97^{3}$ e normas CETESB, especificamente (FINK et al, 2000).

No Brasil, a atividade suinocultura é grande geradora de dejetos, embora predomine em pequenas propriedades rurais (TAKITANE e SOUZA, 2000).

Os dejetos de suínos, até a década de 70 , não constituíam fator preocupante, pois a concentração de animais era pequena, sendo o solo das propriedades capaz de absorvê-los. Outra função para os dejetos era sua aplicação como adubo orgânico.

Notadamente com a intensificação da produção, no confinamento, sem que houvesse a mudança da localização das granjas (geralmente muito próximas aos rios), o problema da poluição ambiental foi agravado. Os dejetos, em maior quantidade, passaram a ser lançados diretamente nos rios, sem que houvesse um adequado procedimento de armazenamento e de tratamento, transformando-se na maior fonte poluidora dos mananciais de água. Disposto como fertilizante, constitui-se em provável fonte difusa de poluição (NEVES et al, 2005a).

Para Matos et al. (1995) apud Pretto (2003) esse é o principal motivo que, nos últimos 15 anos, fez aumentar a atenção às necessidades de desenvolvimento tecnológico com vistas a obter uma melhor forma de disposição dos resíduos no sentido da diminuição dos impactos provenientes.

A exemplo do problema ambiental relacionado à questão dos dejetos, está a produção suína no Estado de Santa Catarina. Segundo Takitane et al (2000), os problemas causados pelo lançamento dos dejetos de suínos in

\footnotetext{
${ }^{2}$ CONAMA - Conselho Nacional do Meio Ambiente. Resolução 1, de 23 de Janeiro de 1986.

${ }^{3}$ Resolução CONAMA 237 de 19 de Dezembro de 1997.
} 
natura nos cursos d'água vêm provocando sérios danos ambientais, ainda sem a devida fiscalização e controle por parte dos órgãos estaduais e federais.

O serviço de Extensão Rural de Santa Catarina avaliou que cerca de $85 \%$ das fontes de água do meio rural das regiões produtoras estão contaminadas com coliformes fecais, os quais se originam do lançamento de dejetos de suínos em cursos ou mananciais d'água (OLIVEIRA, 1983).

Em conformidade com as citações anteriores, Belli Filho et al (2000) destacam que apenas $15 \%$ dos produtores de suínos executam alguma forma de manejo e/ou valorização dos dejetos gerados na atividade.

Características da bacia hidrográfica (principalmente edafoclimáticas), são variáveis importantes para o carreamento dos dejetos para os mananciais, em processos erosivos.

Segundo Roppa (2001), um suíno defeca o equivalente ao que 2,5 pessoas defecam. $O$ volume de dejetos gerados depende da fase da vida em que o suíno se encontra, conforme demonstrado pela Tabela 6.

Tabela 6. Produção média diária de dejetos nas diferentes fases da vida dos suínos.

\begin{tabular}{|c|c|c|}
\hline $\begin{array}{c}\text { Categoria } \\
\text { animal }\end{array}$ & $\begin{array}{c}\text { Peso médio } \\
\text { (kg) }\end{array}$ & $\begin{array}{c}\text { Dejetos produzidos } \\
\text { (kg/dia) }\end{array}$ \\
\hline Creche & 16 & 1,1 \\
Crescimento & 30 & 1,9 \\
Terminação & 68 & 4,5 \\
Gestação & 125 & 4,1 \\
Porcas + leitões & 170 & 15,0 \\
Cachaço & 100 & 5,0 \\
\hline
\end{tabular}

Fonte: Adaptado de Merkel (1981)

Dados da EMBRAPA/CNPSA indicam que dejeto sólido de suíno, seco a $65^{\circ} \mathrm{C}$, contém $2,1 \%$ de nitrogênio; $2,8 \%$ de $\mathrm{P}_{2} \mathrm{O}_{5} ; 2,9 \%$ de $\mathrm{K}_{2} \mathrm{O}$ e $25 \%$ de matéria seca. Ainda segundo a EMBRAPA/CNPSA doses de esterco de 3,5 e 4,2 t/ha/ano (peso seco) são suficientes para manter a produtividade relativa do milho entre $90 \%$ e $95 \%$ do teto máximo. 
Ishizuka, 2002, apud Pretto, 2003, já preconizara que os problemas ambientais gerados pelos dejetos de suínos não se restringem ao grande volume produzido ou carga de nutrientes, mas também a composição microbiológica dos mesmos. Dentre os agentes patogênicos passíveis de veiculação pelos dejetos estão a E.coli, Salmonella sp, Myc.Tuberculosis, Brucella suis, Streptococcus sp, o vírus da peste suína clássica e da febre aftosa.

Em relação à saúde humana, Takitane e Souza (2000) elencaram duas das principais preocupações das autoridades sanitárias em relação aos dejetos:

\section{a. Doenças infecciosas}

Os problemas epidemiológicos constatados no meio rural estão relacionados com os agentes causadores de infecções dentro das propriedades. A prevenção de fatores que contribuem para sua ocorrência é a proteção dos animais contra o risco de infecções e proteção do público em geral contra zoonoses ou outros riscos sanitários provocados pelo lançamento de resíduos de animais nos cursos d'água. Os problemas epidemiológicos ligados aos grandes sistemas de confinamento estão intimamente relacionados com 0 manejo de esterco animal (OLIVEIRA,1993).

\section{b. Gases nocivos}

Os principais gases nocivos existentes em torno dos sistemas de confinamento são: amônia, sulfeto de hidrogênio, dióxido de carbono e metano. Segundo Oliveira (1993), os odores são produzidos pela amônia, sulfeto de hidrogênio e por inúmeros compostos orgânicos intermediários resultantes da decomposição biológica da matéria orgânica do esterco. De acordo com Schiffman (1998), apud V. Oliveira (2001), os odores afetam a saúde física e psíquica, alteram a memória e o humor das pessoas; tanto as que trabalham na propriedade como na vizinhança e até mesmo nas comunidades vizinhas. 
Para o $\mathrm{MDA}^{4}$, o dejeto de uma suinocultura, se não for manejado convenientemente, torna-se um poderoso poluidor ambiental. Por isso a utilização de dejetos de suínos não deve ser concebida como alternativa de renda, mas como meio de diminuir ou eliminar sua ação poluidora do meio ambiente com menor custo.

A falta de um manejo adequado dos resíduos, acabando por lançá-los em cursos d'água, tem causado sérios desequilíbrios ecológicos em vários países, dentre eles o Brasil, que apresenta um grande potencial para atender à demanda mundial crescente por proteínas de origem animal, especialmente pelo advento dos embargos aos produtos de origem animal de vários países assolados pelo "mal da vaca-louca"(principalmente os EUA) e "gripe do frango"(países Asiáticos).

\subsubsection{Uso dos dejetos de granjas na agricultura}

Os dejetos provenientes das granjas de aves e suínos, têm sido amplamente utilizados como fertilizante em culturas. Um exemplo desta utilização é a região de Rio Verde, localizada no Sudoeste Goiano, sendo considerada um importante pólo brasileiro de produção agropecuária, destacando-se as culturas de soja, milho e algodão e a pecuária de corte.

Por ser a maior região produtora de grãos do estado de Goiás, nos últimos anos, as grandes empresas produtoras de carnes, principalmente de aves e de suínos, vêm transferindo suas operações da região Sul para a região Centro Oeste, devido a grande demanda de grãos e existência de grandes propriedades nas quais os dejetos podem ser empregados como fertilizante (MENEZES et al, 2002).

Sendo uma importante fonte de nutrientes, especialmente o Nitrogênio (Tabela 07), os dejetos de aves e suínos podem ser manejados adequadamente, suprindo, parcial ou totalmente, os fertilizantes químicos na agricultura, sendo considerados insumos de baixo custo.

\footnotetext{
${ }^{4}$ MDA - Ministério do Desenvolvimento Agrário
} 
Menezes et al (2002), descreveram experimentos de plantio direto com fertilização com dejetos, conduzidos no campus da Fundação de Ensino Superior de Rio Verde (FESURV) nas safras de 2000/2001 (Figura 1) e 2001/2002, na fazenda Fontes do Saber, em Rio Verde, GO, onde a característica de solo é Latossolo vermelho mesoférrico mesoférrico, textura argilosa, ocupando uma área de seis hectares.

Tabela 7. Características químicas dos dejetos de aves e suínos.

\begin{tabular}{|c|c|c|c|c|c|c|c|c|c|c|}
\hline \multirow{2}{*}{ Resíduo } & $\mathbf{p H}$ & MO & II & $\mathbf{P}$ & K & Ca & Mg & $\mathbf{S}$ & Cu & Zn \\
\hline & ------ & ----- & ------ & ------- & gidm ${ }^{3}-$ & ----- & --- & -----י-" & \multicolumn{2}{|c|}{--- m gidm ${ }^{3}--$} \\
\hline $\begin{array}{l}\text { Dejetos } \\
\text { suínos }\end{array}$ & 8,18 & 25,43 & 25,20 & 12,23 & 87,20 & 26,33 & 4,91 & 5,58 & 674,40 & 246,00 \\
\hline $\begin{array}{c}\text { Cama-de- } \\
\text { frango }\end{array}$ & 8,55 & 35,90 & 29,70 & 26,30 & 23,40 & 34,10 & 6,70 & - & - & - \\
\hline
\end{tabular}

Fonte: FESURV, Rio Verde (GO)

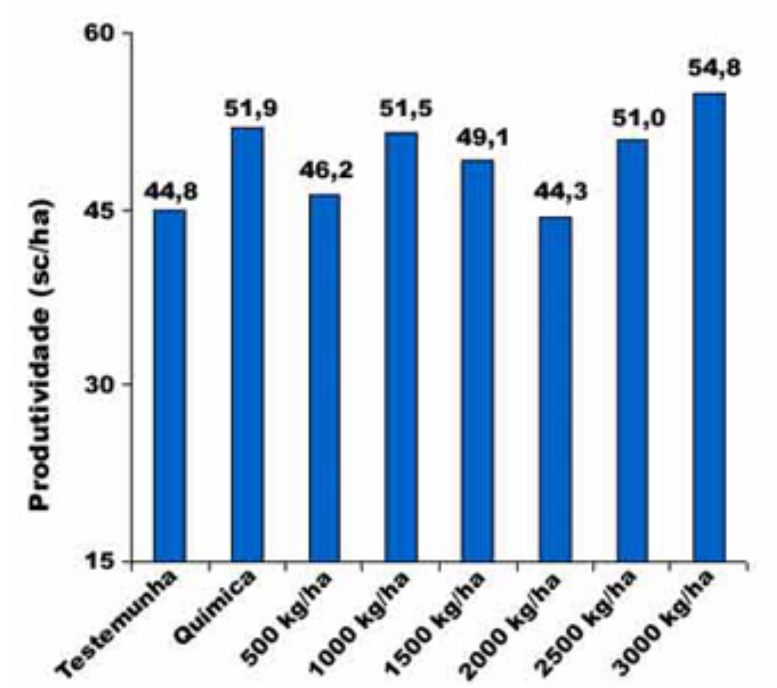

Figura 1. Produtividade média de soja (sacos/ha) em função de doses crescentes de cama de frango. Safra 2001/2002.

Fonte: FESURV, Rio Verde (GO) 
Algumas pesquisas, como a demonstrada, informam a viabilidade técnica da utilização de dejetos de suínos estabilizados e cama-de-frango como fertilizante para a produção de grãos. Em todos os casos de aplicação, houve uma resposta satisfatória da produtividade, comparando-se à adubação química.

Todavia, são poucos os trabalhos na literatura que avaliam o impacto ambiental da utilização de dejetos como fertilizante.

Os dejetos de suínos, se utilizados inadequadamente, podem afetar as propriedades do solo e se constituir numa fonte de contaminação ambiental. Os riscos de contaminação podem ocorrer devido à lixiviação de solutos como nitrato e pelo acúmulo de elementos, tais como cobre e zinco, no perfil do solo até atingir níveis tóxicos, podendo ainda ser uma fonte importante de contaminação de águas subterrâneas (Figura 2).

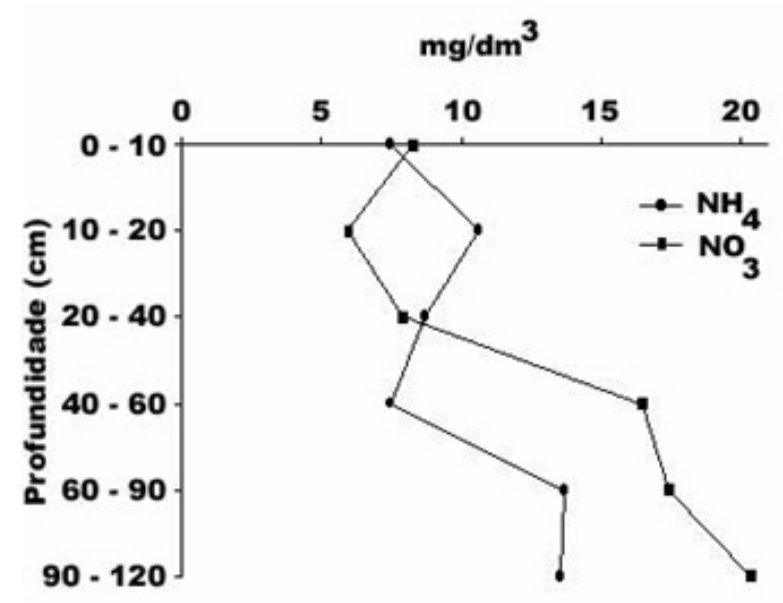

Figura 2. Distribuição de amônio (N-NH4+) e nitrato (N-NO3-) no perfil do solo com aplicação de 100 m3/ha de dejetos líquidos de suínos no cultivo da soja.

Fonte: Rio Verde, ESUCARV, 2001. 


\subsubsection{Uso dos dejetos de granjas na pecuária}

O uso da cama de frango na alimentação de bovinos de corte em confinamento e de vacas leiteiras é muito difundido, principalmente nas regiões onde a avicultura de corte está presente em maior escala.

Entende-se por cama de frango o produto resultante da acumulação do esterco avícola, penas e alimento desperdiçado sobre um material usado como piso, como cascas de arroz ou amendoim, sabugo de milho, etc (MELOTTI, et al, 1998).

A cama de frango é uma fonte de nitrogênio não protéico de baixo custo e disponível em grande quantidade no Estado de São Paulo.

A composição química da cama de frango varia de acordo com o tipo de material utilizado para piso (Tabela 8), tempo de criação, número de lotes criados no mesmo piso, número de aves por metro quadrado e tempo de estocagem.

Para Melotti, et al (1998), a produção anual da cama de frango no Brasil pode ser estimada em 3 milhões de toneladas, considerando que um frango de corte produza $1,5 \mathrm{~kg}$ de esterco durante o período de criação (49 dias), adicionando-se ainda o peso do material utilizado como piso.

Tabela 8. Composição química das camas de frangos com base na matéria seca, em percentual.

\begin{tabular}{|l|l|l|l|}
\cline { 2 - 4 } \multicolumn{1}{c|}{} & \multicolumn{3}{c|}{ Material utilizado como piso } \\
\cline { 2 - 4 } \multicolumn{1}{c|}{} & $\begin{array}{c}\text { Casca de } \\
\text { Arroz }\end{array}$ & $\begin{array}{c}\text { Casca de } \\
\text { Amendoin }\end{array}$ & $\begin{array}{c}\text { Sabugo de } \\
\text { Milho }\end{array}$ \\
\hline Matéria seca & 92,80 & 91,20 & 92,75 \\
\hline Proteína bruta & 20,40 & 24,14 & 27,59 \\
\hline Fibra bruta & 21,71 & 21,44 & 17,20 \\
\hline Matéria mineral & 21,39 & 17,60 & 17,02 \\
\hline
\end{tabular}

Fonte: Modificado de MELOTTI et al, 1998 
Dentre as utilizações possíveis para a cama de frango, as mais freqüentes são o uso como fertilizante agrícola e na alimentação de ruminantes.

Para Bhattachrya et al, apud Melotti et al (1998), o nitrogênio protéico corresponde $40 \%$ a $50 \%$ do total em peso das camas, e o não protéico encontra-se principalmente na forma de ácido úrico, sendo este nutriente importante e utilizado eficientemente por ruminantes. A cama de frango é também fonte considerável de energia, após digestão da matéria seca.

Não obstante às características nutricionais do uso da cama de frango, esta prática está proibida por Instruções Normativas do Ministério da Agricultura, Pecuária e Abastecimento (MAPA).

Embora proibido, o subproduto ainda vem sendo utilizado por criadores. O MAPA está desencadeando, junto aos Estados, campanha educativa para cumprimento das Instruções Normativas, uma vez que o Brasil está no seleto grupo de risco 1 (praticamente inexistente) para a Encefalopatia Espongiforme Bovina (BSE), ou doença da vaca louca. Em torno de $98 \%$ do rebanho bovino nacional é alimentado a pasto, mas $2 \%$ ainda são engordados intensivamente, com uso de produtos diversos. A cama aviária é uma das opões mais baratas.

Portanto, é importante a adoção das medidas propostas pela Organização Internacional de Epizootias (OIE), entre elas a não utilização de proteína animal e gorduras na alimentação do gado.

Muito embora o problema esteja sendo discutido e avaliado em relação à alimentação de ruminantes com rações formuladas com derivados animais, ainda não se discutiu sobre o contato destes animais com os dejetos de suínos e aves que são lançados nos pastos como fertilizantes.

É importante evidenciar que as Instruções Normativas do MAPA não são restritivas em relação à alimentação de aves e suínos com derivados animais.

Durante o processo de abastecimento dos comedouros de aves, em criações confinadas, pode haver contaminação da cama de frango com ração 
formulada a base de proteína ou gordura de ruminantes, o que, finalmente, estaria disponível para o gado após fertilização de pastos com este substrato.

A discussão em torno do tema busca resguardar a qualidade sanitária do rebanho brasileiro, uma vez que a alimentação de ruminantes com derivados animais pode dar causa à Encefalopatia Espongiforme Bovina.

\subsection{Problemas sanitários}

\subsection{1 “A gripe do frango" (influenza aviária)}

De acordo com o Ministério da Agricultura Pecuária e Abastecimento e dados de notificações da Organização Internacional de Epizootias (OIE), a influenza aviária é considerada exótica no Brasil, não tendo havido, portanto, casos clínicos nem diagnóstico da doença no plantel avícola comercial do Brasil.

Por definição da OIE (Organização Internacional de Epizootias, do qual o Brasil é signatário), a "Influenza Aviária é uma doença causada por agente pertencente à família Orthomyxoviridae, gênero influenzavirus $A$, subtipos H7 e H5 de alta patogenicidade".

A influenza aviária é classificada como uma das doenças da lista $A$ da OIE e, portanto, de notificação obrigatória, impondo barreira sanitária à comercialização de produtos avícolas no mercado interno e internacional no caso de surtos causados por cepas altamente patogênicas do vírus.

No Brasil a avicultura comercial de corte é altamente tecnificada e apresenta uma das melhores estratégias de controle de biossegurança, se comparada a diversos outros países. A exceção, impondo maiores riscos, são ainda algumas regiões de postura comercial de alta densidade de aves com ausência de medidas mais rigorosas de biossegurança, e áreas onde ainda se praticam feiras livres com comércio de galinhas e outras aves vivas. Isto porque, supõe-se que o comércio de aves vivas, incluindo galinhas, patos, 
marrecos, em proximidade com densa população humana seja um dos fatores associados aos surtos de influenza em humanos na Ásia.

Na Ásia há uma íntima relação de contato entre galinhas comerciais e aves aquáticas, como patos e marrecos, tanto nas áreas rurais como em centros urbanos como ocorre em Hong Kong, onde há inúmeras feiras de comércio de aves vivas, com constante contato entre diferentes espécies de aves e também humanos em áreas densamente povoadas, supondo-se um ambiente mais propício para a disseminação do vírus de influenza.

$\mathrm{Na}$ disseminação de influenza há ainda como hospedeiro intermediário importante o suíno, também comum na Ásia, especialmente em sistemas de produção doméstica e muitas vezes também em contato com galinhas, aves silvestres, gansos, patos, marrecos, entre outras aves silvestres, e pessoas. Este modelo de produção e comercialização, com densa população, tem sido considerado um provável determinante do inesperado "pulo" do vírus aviário diretamente a humanos, ocorrido pela primeira vez com o sorotipo H5N1 aviário em pessoas em Hong Kong, sem a provável necessidade de passagem por hospedeiro intermediário para infectar humanos.

Em relação ao risco para a atividade aviária brasileira, deve-se levar em conta que o Brasil é um importante produtor mundial de frangos e um dos maiores exportadores (ABEF - Associação Brasileira de Produtores e Exportadores de Frango) e, portanto, são necessárias medidas para monitorar e prevenir a influenza aviária em aves comerciais e assim prevenir perdas econômicas e riscos de ocorrência de transmissão do vírus de aves para humanos.

O impacto de um surto de influenza na avicultura comercial brasileira seria devastador em face da queda nas exportações e nas receitas cambiais, além das perdas internas no consumo e comercialização. 


\subsubsection{O mal da "vaca-louca" (Encefalite espongiforme)}

O chamado mal da vaca louca, teve o primeiro caso registrado em dezembro de 1984 na Inglaterra. Em 1986, os britânicos já enfrentavam uma epidemia. Cerca de 200 mil animais foram infectados e 4,5 mil, sacrificados na tentativa de estancar o problema.

Em 1994, a doença, cujo termo médico é encefalite espongiforme devido aos "buracos parecidos com esponja" que ela deixa no cérebro, chegou aos humanos, provavelmente por causa do consumo da carne contaminada.

Até hoje, o número de casos em pessoas é relativamente pequeno. São 137, na maioria na Inglaterra. Porém, a doença causa medo por que é fatal. Ela ataca o cérebro, deixando a vítima mental e fisicamente dependente.

Nos humanos, o mal da vaca-louca lembra uma enfermidade já conhecida dos médicos: a doença de Creutzfeldt-jakob, que danifica as células causando infecção generalizada do cérebro. Alguns testes genéticos levaram os cientistas a concluir que a causa dessa doença humana deveria ser justamente a ingestão de carne contaminada.

O mal da vaca louca e outras doenças relacionadas a desordens cerebrais não são causados por vírus ou bactérias, mas por príons.

Os príons são uma versão defeituosa de uma proteína abundante no cérebro e na coluna vertebral. Por alguma razão (que ainda não se sabe qual), os príons interagem com o DNA do doente produzindo mais proteínas. $O$ acumulo anormal da proteína é o que causa a doença.

\subsubsection{Importância da discussão dos problemas sanitários}

Os recentes fenômenos sanitários impuseram restrições ao consumo de carnes oriundas de vários países, sobretudo os Asiáticos.

Como reflexo econômico, verificou-se o aquecimento do mercado mundial de aves, suínos e bovinos, notabilizando-se aqueles países detentores 
de uma política sanitária rígida e em condições de atender à crescente demanda por carnes, entre eles o Brasil (Revista Veja, edição especial $n^{\circ} 30$ : Agronegócio, Abril de 2004).

O Brasil, conforme anteriormente aludido, ganhou impulso no mercado mundial, não somente em face ao plantel de animais de corte e postura, como também por sua política sanitária rígida, a qual se tem constituído em fator determinante da predileção pela carne brasileira.

No entanto, devido à sua dimensão continental, há que se destacar que não é possível conhecer-se, na sua integralidade, a qualidade dos produtos nacionais.

O questionamento reflete-se na Microbacia em estudo, pois a falta de informações do produtor e o emprego de tecnologias obsoletas ou ineficazes, impactam na qualidade dos produtos e a segurança sanitária das granjas, podendo ter o processo de produção sérios compromotimentos, culminando em um eventual processo de restrição à produção nacional, análogo ao acontecido nos países asiáticos, maculando, desta feita, a reputação brasileira frente ao mercado internacional.

Pela óptica econômica, social e principalmente sanitária, a gestão dos dejetos de animais tem sua fundamentação e importância destacada.

\subsection{Erosão}

Para atender às crescentes demandas da população, tornou-se necessário incorporar novas áreas para produção de alimentos, aumentando conseqüentemente o uso de insumos e agroquímicos. Solos considerados sem aptidão agrícola foram "recrutados" tornando-se fonte de prejuízos e poluição.

Segundo Crestana (2000), o uso contínuo da camada arável do solo, submetida à mecanização pesada e intensa, aliada às práticas de cultivo que desconsideram a importância de sua cobertura, da matéria orgânica e da 
conservação da biodiversidade, entre outros fatores, têm reforçado o aparecimento de problemas associados à compactação, desertificação e aumento da erosão do solo.

Para Costa e Matos (1997), a erosão é o processo pelo qual ocorre o deslocamento das partículas sólidas do solo, induzido fisicamente pelo escorrimento superficial da água.

Silva e Crestana (2004), apud Carvalho (1994), identificam quatro grandes tipos de processos erosivos: erosão eólica, erosão hídrica superficial, erosão por remoção em massa e a erosão fluvial.

\section{- Erosão Eólica}

A erosão eólica, ou erosão provocada pelo vento ocorre quando o terreno está muito seco e as partículas do solo perderam a coesão.

\section{- Erosão Hídrica Superficial}

A erosão hídrica superficial constitui a principal forma de erosão abordada em modelos de simulação e pode se processar em forma de erosão pluvial, erosão por escoamento difuso, erosão por escoamento difuso intenso, erosão laminar e erosão por escoamento concentrado.

O tipo de erosão pluvial é produzida pelo impacto das gotas de chuva ao caírem sobre superfícies desprotegidas. A desintegração parcial dos agregados naturais do solo liberta partículas finas, deslocando-as e projetando-as a uma certa distância. O golpe das gotas afeta primeiramente a estrutura da camada superficial, predispondo a um desprendimento das partículas, que em seguida serão mobilizadas pelo escorrimento.

A erosão por escoamento difuso ou erosão em sulcos é uma forma caracterizada por filetes de água que se dividem em braços que se espalham e juntam constantemente, infiltrando-se depois de pouca distância, depositando o material transportado. Escoando pelo terreno, a água se pode ir formando depressões que pouco a pouco vão aumentando para sulcos. 
A erosão por escoamento difuso intenso é semelhante à anterior, entretanto os filetes de água percorrem distâncias maiores, transportando maior quantidade de material, havendo um escoamento que vai se aprofundando e se concentrando.

A chamada erosão em lençol ou laminar se processa durante as fortes precipitações, quando o solo superficial já está saturado, sendo produzida por um desgaste suave e uniforme da camada superficial em toda sua extensão. Esse tipo de erosão se desenvolve quando há pouco obstáculo, permitindo uma lâmina de água se escoar, sendo um fenômeno muito comum em regiões semi-áridas. É de difícil observação e pode ser percebido pelo aparecimento de raízes ou marcas nas estruturas.

A erosão por escoamento concentrado pode ser provocada por falta de boa estrutura do solo que tenha a camada impermeável profunda, permitindo que os sulcos formados pouco a pouco vão sofrendo deslizamentos e desabamentos, terminando por formar voçorocas. Na Figura 3 apresenta-se o efeito do impacto da gota e seu efeito da erosão por sulco.

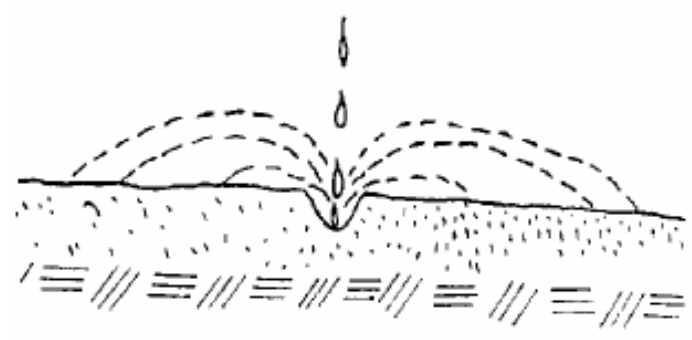

(a)

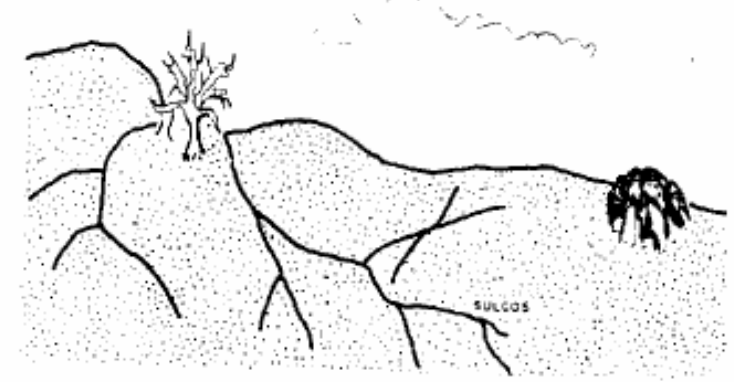

(b)

Figura 3. (a) impacto da gota da água contra o solo; (b) seu efeito e erosão em sulcos. Fonte: Silva e Crestana (2004).

\section{- Erosão por remoção de massa}

A erosão por remoção em massa corresponde a movimentos de uma quantidade substancial de materiais das formações superficiais e de rochas sob a influência combinada de gravidade e de saturação de água - um solo, de 
acordo com o conteúdo de água presente, pode ficar plástico ou líquido, perdendo a coesão interna, assim a ação da gravidade pode permitir a sua deformação. A erosão por remoção em massa pode se processar em várias modalidades, de acordo com o fluxo de material, sendo lento ou rápido (Figura 4).

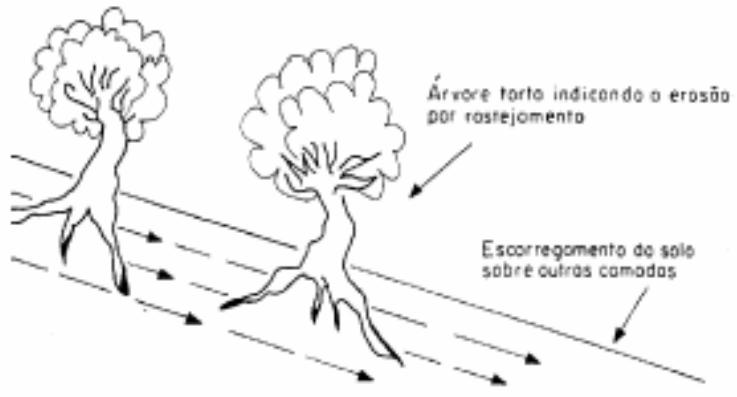

(a)

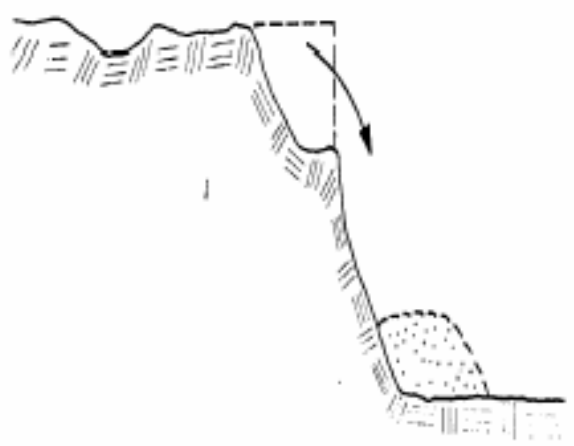

(b)

Figura 4. (a) erosão por remoção de massa do tipo rastejo; (b) erosão por remoção em massa quando há desprendimento de terras.

Fonte: Silva e Crestana (2004).

\section{- Erosão fluvial}

É aquela que se processa de modo contínuo e espontâneo pela ação das correntes dos rios. É de grande interesse na morfologia fluvial, podendo explicar a formação dos rios e da rede hidrográfica.

Como principais conseqüências da erosão ao ambiente, destacam Costa e Matos (1997):

- Aumento da turbidez nos corpos hídricos. O aumento da quantidade de sedimentos em suspensão na água concorre para dispêndios com tratamento de água para consumo humano; influenciam a comunidade biótica de sistemas aquáticos, notadamente os fotossintetizantes.

- Assoreamento de várzeas, vales, calha de rios, represas e outros sistemas aquáticos, prejudicando a manutenção da biodiversidade; 
alterando fisicamente o curso de mananciais; reduzindo a disponibilidade hídrica para irrigação.

- Perda de agroquímicos e outros tipos de fertilizantes aplicados no solo, contaminando cursos d'água, provocando eutrofização; aumentando o consumo de oxigênio dissolvido na água, afetando principalmente a comunidade biótica residente.

Segundo Bertolini et al. (1993) apud Costa e Matos (1997), só no Estado de São Paulo são perdidos, devido à erosão, cerca de 194 milhões de toneladas de terras férteis, das quais 48,5 milhões de toneladas chegam aos mananciais em forma de sedimentos transportados, causando assoreamento e poluição. Quando a erosão ocorre em uma área cultivada, o solo erodido acompanha conjuntamente os nutrientes das plantas.

Dentre os vários elementos químicos aportados aos corpos d'água, o Nitrogênio $(\mathrm{N})$ e o Fósforo $(\mathrm{P})$, merecem importante destaque em relação às atividades rurais, notadamente aquelas onde estão presentes atividades de confinamento de animais e o manejo do dejeto gerado como fertilizante agrícola. Estes elementos ganham destaque por participarem diretamente do metabolismo dos ecossistemas aquáticos (SILVA et al, 2003). O nitrogênio participa da formação de proteínas, um dos componentes básicos da biomassa, e, quando presente em baixas concentrações, pode atuar como fator limitante na produção primária dos ecossistemas aquáticos. O fósforo também atua em processos fundamentais, como armazenamento de energia e estruturação da membrana celular. $\mathrm{Na}$ maioria das águas continentais, o fósforo é o principal responsável pela eutrofização desses ecossistemas (ESTEVES, 1988, apud SILVA et al, 2003).

A exposição dos agroquímicos e outras substâncias utilizadas como fertilizantes do solo, ao transporte, via escorrimento superficial ou lixiviação através do perfil do solo, intensificados por suscetibilidade a processos erosivos, torna-se uma fonte considerável de poluição aos recursos hídricos, sendo importante e de relevante interesse do presente estudo. 


\subsection{A Bacia Hidrográfica como unidade de estudo}

A bacia hidrográfica pode ser definida como unidade física, caracterizada como uma área de terra drenada por um determinado curso d'água e limitada, perifericamente, pelo chamado divisor de águas. Segundo Moldan e Cerny (1994), a microbacia, do ponto de vista hidrológico, pode ser considerada como a menor unidade da paisagem capaz de integrar todos os componentes relacionados com a qualidade e disponibilidade de água como: atmosfera, vegetação natural, plantas cultivadas, solos, rochas subjacentes, corpos d'água e paisagem circundante. Ambientalmente, pode-se dizer que a bacia hidrográfica é a unidade ecossistêmica e morfológica que melhor reflete os impactos das interferências antrópicas, tais como a ocupação das terras com as atividades agrícolas (JENKINS et al., 1994, apud MACHADO, 2002).

A microbacia hidrográfica deve ser utilizada como unidade básica para o planejamento conservacionista, entretanto os trabalhos de manejo $e$ conservação do solo vêm sendo em grande parte, ainda hoje, realizados de maneira isolada, em nível de propriedade. O planejamento conservacionista, levando em conta as características da microbacia hidrográfica, visa a um controle integrado da erosão do solo em toda a área que converge para uma mesma seção de deságüe (CALIJURI et al., 1998).

Em alguns programas, a escala de microbacia hidrográfica vem sendo adotada como preferencial para o planejamento conservacionista e para a efetiva execução de programas de controle de erosão e conservação de recursos hídricos. Exemplos desta consagração são os Programas de Microbacias Hidrográficas (BERTOLINI et al., 1993). Esses programas, principalmente aqueles implantados na região sul do Brasil, vêm servindo de referência e de exemplo internacional de sucesso de agricultura conservacionista (BUSSCHER et al., 1996). Em regiões úmidas, principalmente se o enfoque está relacionado a projetos conservacionistas, a delimitação da microbacia hidrográfica engloba a área de drenagem dos primeiros canais fluviais de fluxo permanente, geralmente coincidindo com os afluentes de um rio principal em nível regional. No entanto, o conceito de bacia de drenagem como um sistema hidrogeomorfológico é mais amplo e define a bacia de 
drenagem como uma área da superfície terrestre que drena água, sedimentos e materiais dissolvidos para uma saída comum, num determinado ponto de um canal fluvial.

Definida desta forma, a bacia de drenagem comporta diferentes escalas, desde uma bacia do porte daquela drenada pelo rio Amazonas, até bacias com poucos metros quadrados que drenam para a cabeceira de um pequeno canal erosivo (COELHO NETTO, 1994, apud MACHADO, 2002).

O conceito adotado para a delimitação da bacia de drenagem deve garantir que a área escolhida seja integradora de todos os processos envolvidos no objetivo da análise e que apresente um certo grau de homogeneidade, de forma que estratégias, ações e conclusões gerais possam ser estabelecidas para toda a área delimitada. No caso de programas conservacionistas, o principal objetivo é o controle da erosão, que consiste no processo mais diretamente relacionado com a perda de potencial produtivo das terras agrícolas e com a degradação dos recursos hídricos (LAL, 1990).

As ações governamentais relacionadas ao manejo e conservação dos solos e recursos hídricos são elaboradas nesta escala. Segundo Bertolini et. al. (1993), em São Paulo, “através do Programa Estadual de Microbacias Hidrográficas, os Governos Estadual e Municipal e as associações de agricultores estão iniciando um trabalho visando a adequar o aumento da produção de alimentos para atender ao consumo interno e gerar excedentes para o mercado externo, melhorando o padrão de vida do agricultor e, ao mesmo tempo, utilizando de modo racional e integrado os recursos naturais do solo, da água, flora e fauna".

Da mesma forma, em outros Estados, como o Paraná, há programas de Microbacias Hidrográficas com resultados muito positivos, principalmente na adequação do uso e manejo das terras de maneira a proporcionar um padrão agrícola economicamente viável e ambientalmente sustentável (MARIANO, 1996 apud, MACHADO, 2002). 
Importante destacar que, segundo o autor, a bacia hidrográfica é considerada como área de influência a partir da resolução no 001/86 do CONAMA (Conselho Nacional do Meio Ambiente), de 1981, passando a ser considerada como a área a ser analisada no estudo de impacto ambiental.

\subsection{Poluição em bacias hidrográficas}

Neste sentido, Tucci (1998), destaca características da qualidade da água, como necessária a definição de alguns conceitos importantes:

a) parâmetros de qualidade da água:

- conservativos - não são alterados devido a reações químicas e biológicas internas do rio;

- não-conservativos - são aqueles que reagem por processos químicos e biológicos internos, modificando sua concentração.

b) tipos de cargas numa bacia hidrográfica:

- pontuais - são contribuições em locais específicos dos sistemas devido a despejos de afluentes, de efluentes doméstico ou industrial, entre outros;

- difusas - são contribuições distribuídas no espaço em trechos de rios, lagos, reservatórios, etc.

c) tipos de usos da água:

- consuntivo - usos que impõem a retirada de água das coleções, como, porexemplo, abastecimento público, industrial (alguns tipos) e irrigação;

- não-consuntivo - usos em que não se observa a necessidade de retirar as águas das coleções hídricas, tais como: recreação e lazer, preservação da flora e fauna, geração de energia, transporte e diluição de efluentes (DERISIO, 1992).

Importa definir o que se considera como poluição. A Lei nº 6938 de 1981, Política Nacional de Meio Ambiente, define poluição como: 
"degradação da qualidade ambiental resultante de atividades que direta ou indiretamente prejudiquem a saúde, a segurança e o bem-estar da população; criem condições adversas às atividades sociais e econômicas; afetem desfavoravelmente a biota; afetem as condições estéticas ou sanitárias do meio ambiente; lancem matérias ou energia em desacordo com os padrões ambientais estabelecidos"

A avaliação das condições de poluição (Tabela 9) e alteração dos recursos hídricos pode ser realizada utilizando-se de parâmetros técnicos significativos associados a um uso e a um objetivo específico. No Brasil, a resolução CONAMA n 20 de 1986 é a legislação em vigor que define os padrões de qualidade da água a serem mantidos num corpo d’água de acordo com o uso a que se destina. 
Tabela 9. Caracterização das principais fontes de poluição e seus principais efeitos poluidores.

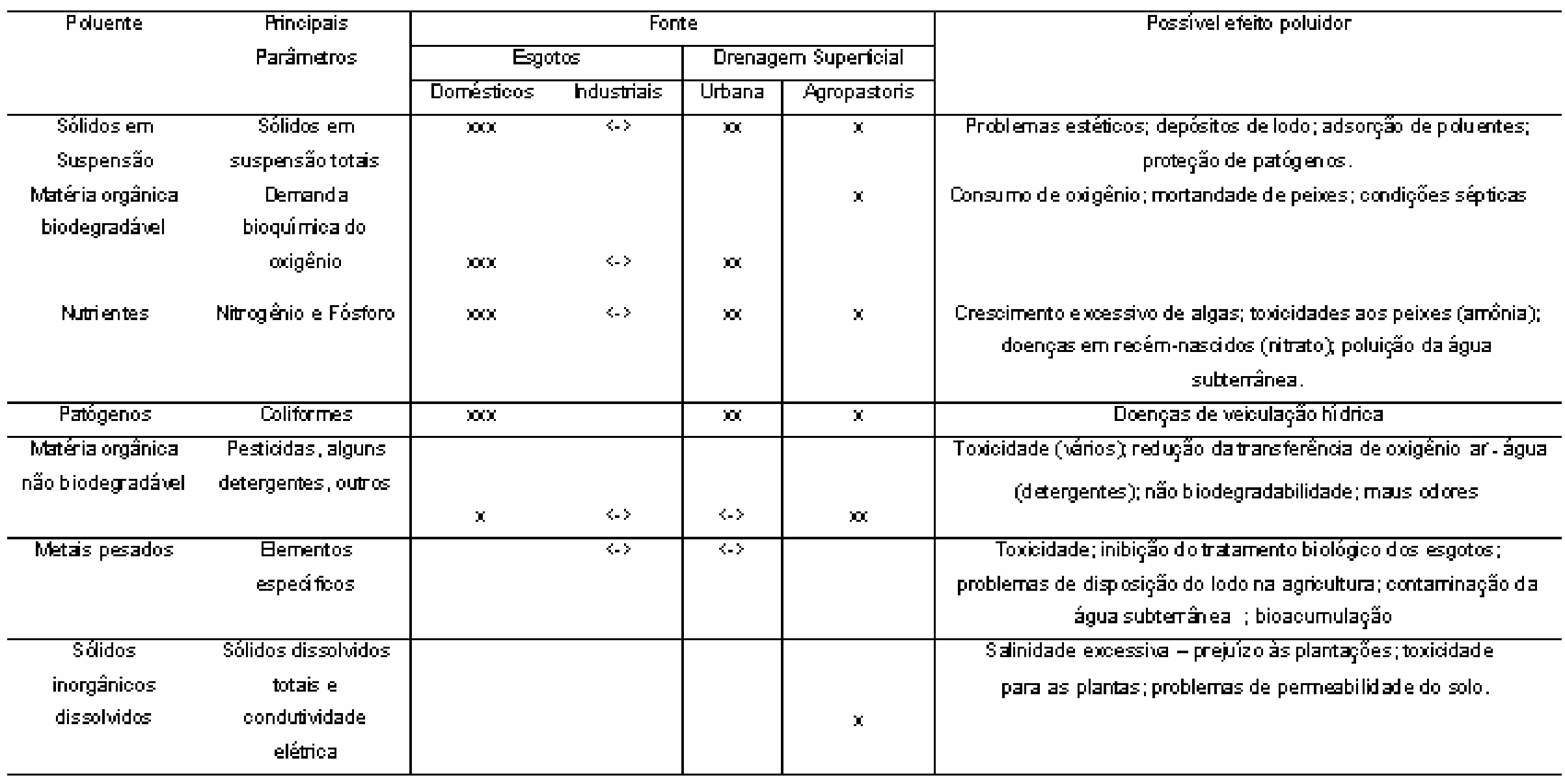
x: pouco xx: médio
xxx: muito
<->: variável
em branco: usualmente não importante

Fonte: Garrido (2003). 
Os parâmetros de qualidade da água são divididos em três grandes grupos: físicos, químicos e biológicos. Os físicos têm relevância na percepção do homem em relação à água percebida por meio de seus sentidos, envolvendo aspectos de ordem estética e psicológica. São exemplos cor, turbidez, sabor, odor, sólidos, temperatura, calor específico, densidade e condutividade elétrica.

Os químicos representam a presença de substâncias químicas dissolvidas na água.

Segundo Porto (1991), esses parâmetros são os mais importantes para a caracterização da qualidade dos recursos hídricos, pois permitem a classificação segundo o conteúdo mineral, o grau de contaminação e a origem dos contaminantes; além da análise do equilíbrio bioquímico para a manutenção da vida no corpo d'água. São avaliados pH, alcalinidade, acidez, dureza, ferro e manganês, cloretos, nitrogênio, fósforo, oxigênio dissolvido, micropoluentes inorgânicos e orgânicos, e matéria orgânica - geralmente medida pela demanda bioquímica de oxigênio (DBO), demanda química de oxigênio (DQO); ou medida pelo carbono orgânico total (COT).

Os biológicos são representados pelos microorganismos que desempenham grande importância nas transformações de matéria no ciclo biogeoquímico e na possibilidade de transmissão de doenças, por meio da ação dos agentes patogênicos como bactérias, protozoários e vírus. O potencial de uma água transmitir doença é geralmente medido de forma indireta considerando a análise dos organismos indicadores de contaminação fecal, com ênfase nas bactérias do grupo coliforme, que são indicadores de presença de fezes de animais de sangue quente, podendo, portanto, vir a transmitir doenças (VON SPERLING, 1996).

Segundo Von Sperling (1996), os principais parâmetros a serem investigados numa análise de água de rio devem ser: físicos - cor, turbidez e temperatura; químicos - $\mathrm{pH}$, nitrogênio, fósforo, oxigênio dissolvido (para controle do processo de tratamento), matéria orgânica, micropoluentes 
orgânicos e inorgânicos (a serem definidos de acordo com o uso e ocupação do solo na bacia hidrográfica de estudo); e biológicos - organismos indicadores.

Neste sentido, o enfoque na prevenção à poluição em nível de microbacias é mais suscetível de resultados em face a estas serem componentes (unidades) de uma determinada bacia hidrográfica, gerando eficácia do manejo da qualidade da água (CALIJURI \& OLIVEIRA, 2000).

\subsection{Modelos matemáticos de simulação}

Tucci (1998) define modelo como "a representação de algum objeto ou sistema, numa linguagem ou forma de fácil acesso e uso, com o objetivo de entendê-lo e buscar suas respostas para diferentes entradas."

Dentre os tipos de modelos existentes na área de recursos hídricos, os matemáticos têm diversas aplicações, como a quantificação de processos do ciclo hidrológico na análise de qualidade das águas em rios, reservatórios, aqüíferos subterrâneos, nos processos hidráulicos do escoamento da água em rios, mares e subsolo e nos modelos ambientais e meteorológicos (AZEVEDO et al., 1997).

Os modelos matemáticos de simulação permitem uma grande flexibilidade por possibilitarem que um sistema qualquer seja representado matematicamente em modelos computacionais, além de possibilitar a análise no nível de detalhamento requerido (AZEVEDO et al., 1997).

Um dos benefícios e melhorias para o processo de planejamento de bacias hidrográficas advindos do uso de modelos de simulação é a base de dados necessária para construir e calibrar o modelo, pois muitos problemas podem ser resolvidos ou identificados pela análise dos dados e compilação dos mesmos quando da formatação apropriada para entrada no modelo (NOVOTNY \& OLEM, 1993). Acrescenta-se o fato de muitos modelos apresentarem interface com o ambiente SIG, o que facilita a visualização e 
acesso às informações, além de possibilitar a reunião de diversas fontes de dados (gráficos, planilhas, textos, mapas e imagens) num único ambiente.

Os modelos matemáticos de simulação utilizados na área de recursos hídricos podem ser identificados de acordo com suas principais características. DeVries e Hromadka (1992) sugerem a divisão a seguir:

- modelos chuva-vazão: os cálculos são realizados de montante para jusante seguindo a ordem - precipitação média em sub-bacias; determinação da precipitação excedente; geração do hidrograma de escoamento superficial devido ao excedente de precipitação; adição de escoamento de base simplificado ao hidrograma anterior; propagação da vazão no rio e no reservatório; e, finalmente, combinação de hidrogramas. O principal interesse é a construção do hidrograma de cheia, não havendo grande preocupação com o cálculo de evapotranspiração e de variação da quantidade de água no solo durante e entre períodos de precipitação ou detalhamento do escoamento de base. Exemplos: HEC-1 (Hydrologic Engineering Center), TR-20 (Computer Program for Project Formulation Hydrology - Technical Release 20 - U.S. Soil Conservation Service), ILLUDAS (Illinois Urban Drainage Area Simulator Illinois State Water Survey), DR3M (Distributed Routing Rainfall-Runoff Model U. S. Geological Survey);

- modelos de simulação contínua de vazão: consideram a variação temporal da precipitação e o movimento da água em toda bacia hidrográfica até a sua foz. Há preocupação com o armazenamento da água durante os períodos sem chuva, por isso é dada importância à umidade do solo, à evapotranspiração e às vazões de base subsuperficiais e subterrâneas. São, em sua maioria, modelos fisicamente fundamentados que buscam descrever os principais processos do ciclo hidrológico, a saber: interceptação da precipitação pela vegetação; evapotranspiração; infiltração; escoamento superficial; escoamento nos canais; fluxo subsuperficial. Exemplos: SWRRB (Simulator for Water Resources in Rural Basins - U.S. Department of Agriculture); PRMS (Precipitation-Runoff Modeling System - U.S. Geological Survey); SHE (Systéme Hydrologique Européen - Danish Hydraulic Institute, U.K. Institute of 
Hydrology e SOGREAH) e IPH II, III, IV e IPHMEN (Instituto de Pesquisas Hidráulicas da Universidade Federal do Rio Grande do Sul) (Tucci, 1998);

- modelos de fluxo-hidráulico: calculam o fluxo de água em canais, rios e córregos. Geralmente são utilizados para análise de vazões em trecho de rio sob pontes eescoamento de água em galerias. Na elaboração dos cálculos, duas situações podem ser consideradas: fluxo permanente ou nãopermanente, com estudos de escoamentos uniforme e não-uniforme subcrítico, crítico ou supercrítico. Exemplos: HEC-2 (Hydrologic Engineering Center), WSPRO (Water-Surface PROfile - U.S. Geological Survey), FLDWAV-NWS (NWS National Weather Flood Wave Model - U. S. National Weather Service) e o DHM (Diffusion Hydrodynamic Model - Computational Hydrology Institute);

- modelos de qualidade da água: necessitam da determinação dos dados de quantidade de água no rio para análise da qualidade. Usualmente requerem que as características hidráulicas e de cargas lançadas no rio sejam dados de entrada ao sistema. Exemplos: SWMM (Storm Water Management Model - U.S. Environmental Protection Agency); HSPF (Hydrologic Simulation Program - FORTRAN - U.S. Environmental Protection Agency), QUAL2E (Enhanced Stream Water Quality Model - Texas Water Development Board); WASP4 (Water-Quality Simulation Program - U.S. Environmental Protection Agency), AGNPS (Agricultural Nonpoint Source Pollution Modeling System U.S. Agricultural Research Service) e MIKE11 (Danish Hydraulic Institute).

Considerando a classificação proposta por DeVries e Hromadka (1992), modelos como o ANSWERS (Areal Nonpoint Source Watershed Environmental Response Simulation), SWAT (Soil and Water Assessment Tool), SWRRBWQ (Simulator for Water Resources in Rural Basins - Water Quality) e WATFLOOD, a serem citados no subitem 3.4, deveriam estar classificados como modelos de qualidade da água e de simulação contínua de vazão simultaneamente, visto que agregam as duas análises. 


\subsection{Modelos hidrossedimentológicos}

De acordo com Silva e Crestana (2004), existem inúmeros modelos para a estimativa de perda de solo. Geralmente se distinguem pela existência de diferentes tipos de classificação, principalmente em função de: (a) área de aplicação (plot, pequenos lotes ou bacias), (b) se os algoritmos e relações são baseados em leis físicas ou leis empíricas, (c) se o fluxo sub-superficial e/ou subterrâneo são considerados e, (d) tipo de parâmetros que são simulados (hidrológicos, sedimentos, nutrientes e/ou pesticidas).

Em relação à escala espacial de aplicabilidade, a maioria dos modelos estima a perda de solo em pequenas áreas homogêneas, com inclinação uniforme. Estes modelos são geralmente aplicados a áreas variando entre pequenos plots (0.01 ha) a pequenas bacias (aproximadamente $10 \mathrm{ha}$ ). Com o advento da tecnologia SIG, modelos espacialmente distribuídos aplicados em áreas maiores têm sido utilizados em estudos de produção de sedimentos na escala de bacias hidrográficas. Jetten et al. (1999) apud Silva e Crestana (2004), apontam como principal vantagem destes modelos a possibilidade de estudos de conservação ambiental através da estimativa do escorrimento superficial, sedimentos e elementos químicos produzidos pela bacia. Entretanto, os autores alertam que a incerteza dos resultados aumentam devido a problemas associados a complexidade dos processos e do erros devido a variabilidade espacial.

Importante ressaltar também a necessidade de se conhecer o modelo conceitual hidrológico que invariavelmente faz parte de todos os modelos, já que sedimentos e componentes químicos são transportados via água. Portanto um modelo conceitual não adequado irá resultar em valores discutíveis.

Outro fator de grande relevância é a compreensão dos fenômenos físicos ocorrentes na bacia hidrográfica de interesse, representados pelas Figuras 5 e 6 , bem como a disponibilidade de dados reais para serem processados pelo modelo em estudo, diminuindo as incertezas dos resultados simulados. 


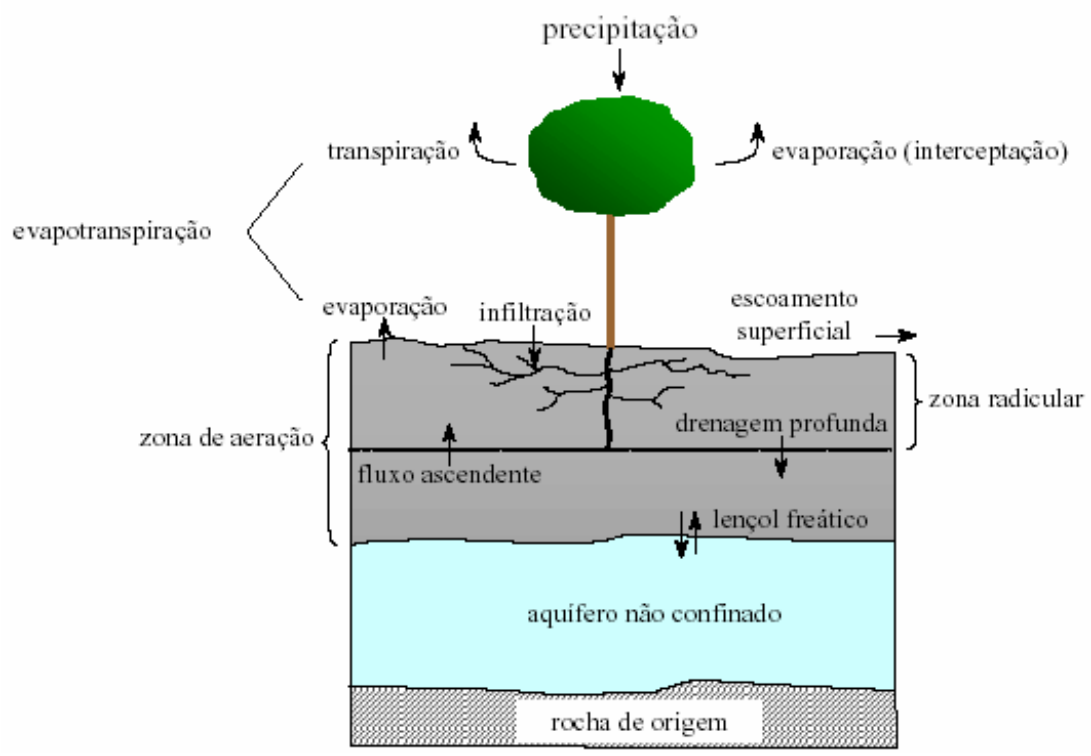

Figura 5. Diagrama dos principais componentes do ciclo hidrológico.

Fonte Renno e Soares (2003)

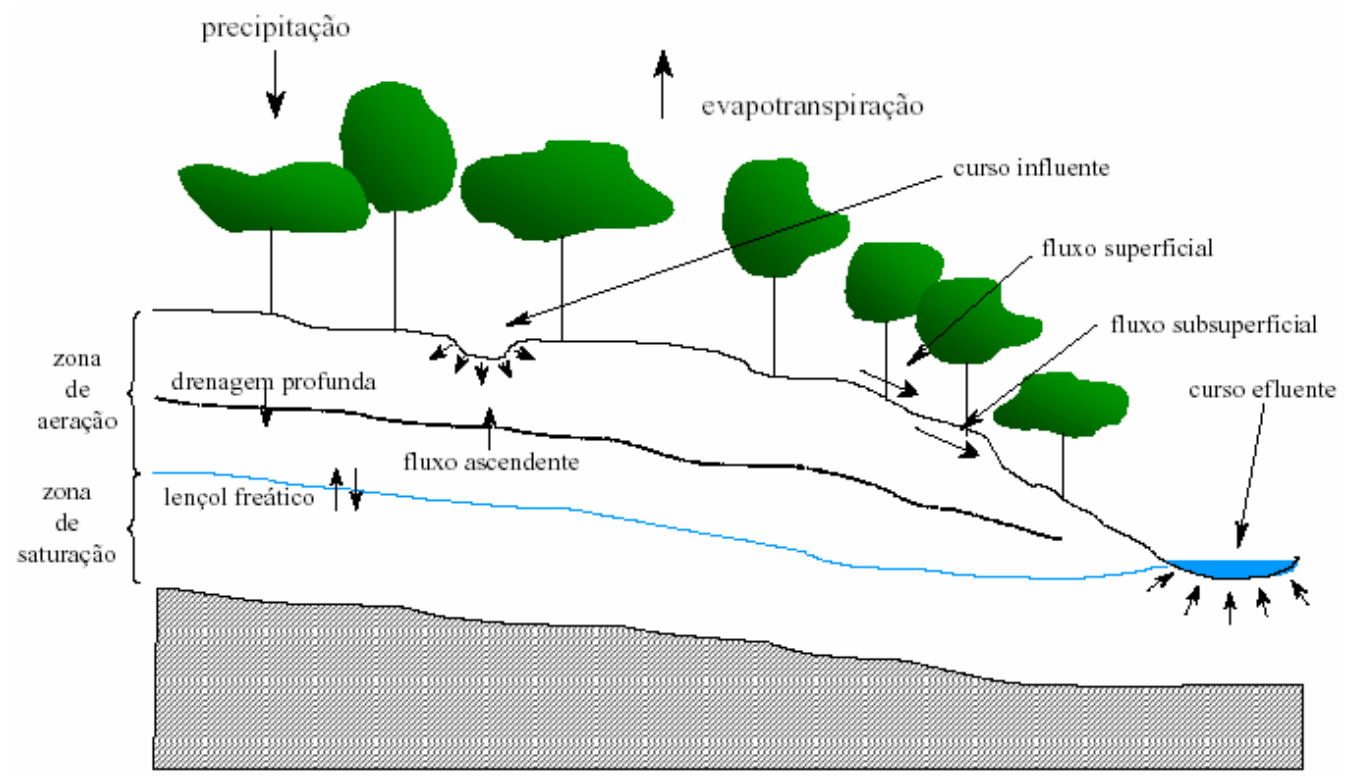

Figura 6. Componentes do balanço de água no solo considerando o declive do terreno. Fonte Renno e Soares (2003).

Silva e Crestana (2004) definiram e discorreram sobre alguns dos principais modelos hidrossedimentológicos, a saber:

- ANSWERS (Areal Nonpoint Source Watershed Environment Response Simulation). O Modelo ANSWERS foi desenvolvido nos anos 70 para ser um pacote computacional utilizado em estudos de gerenciamento e 
planejamento de qualidade da água. Foi o primeiro modelo hidrológico distribuído e logo, tornou-se popular entre pesquisadores. Este modelo subdivide a área em células uniformes de 0,4 a 1 ha. Todos os parâmetros relacionados ao uso da terra, inclinação, propriedades do solo, nutrientes, cultivo e práticas agrícolas são assumidos uniformes para cada célula. A diferença entre as células simula a heterogeneidade do terreno. Existem muitas versões do modelo ANSWERS, a atual (ANSWERS-2000) é um modelo contínuo desenvolvido nos meados dos anos 90 onde os submodelos de nutrientes e infiltração foram melhorados. O modelo ANSWERS visa principalmente a simulação dos aspectos de transformação e interação de vários componentes químicos nos corpos de água, como nitrogênio orgânico, nitrato e amônia. O submodelo de erosão é empírico e somente estima transporte de sedimentos de uma maneira superficial. O ANSWERS não representa os complexos elementos físicos de transporte de sedimento e erosão.

- EPIC (Erosion Productivity Impact Calculator). O modelo EPIC é um modelo de simulação contínua (pode ser usado para uma seqüência de eventos), desenvolvido para avaliar os efeitos da erosão de solo na produtividade. Entretanto, seu uso tem sido estendido para as mais variadas aplicações relacionadas com meio-ambiente em geral. O modelo é aplicado para áreas de até 100 ha, e é fortemente baseado na USLE. O modelo oferece seis opções de cálculo de erosão incluindo a USLE e outras cinco variações. É um modelo que assume ser a erosão ocorrente em uma área espacialmente homogênea (clima, solos, e uso da terra são homogêneos) e de inclinação uniforme, desprezando as variações espaciais.

- WESP (Watershed Erosion Simulation Program). O WESP representa um modelo físico, de parâmetro distribuído, de evento orientado, não linear. É capaz de prever mudança de topografia, superfície de rugosidade, propriedades do solo e geometria dos canais de fluxo. Os fluxos no solo e nos canais são considerados unidimensionais e descritos por aproximações de ondas cinemáticas. A oscilação e variação espacial dos processos de erosão e deposição na superfície e fluxo nos canais são considerados dinamicamente como um processo simultâneo e a rede de erosão e deposição é obtido pelo balanço de massa. A bacia é representada por uma geometria simplificada 
formada por planos e canais. Cada plano é representado por valores médios de comprimento, largura, inclinação e rugosidade e representa o fluxo por zona de solo. Cada canal é identificado pela sua geometria (trapezoidal ou triangular ou retangular), superfície e plano de declividade, espessura de fundo e coeficiente de rugosidade. O modelo WESP tem 3 grandes componentes: um componente hidrológico este processa a entrada de histogramas de chuva; o componente de escorrimento superficial; erosão e componente de depósito.

- CHDM (Catchment Hydrology Distributed). O modelo CHDM usa parâmetros espacialmente distribuídos, ou seja, considera o sistema hidrológico como uma unidade heterogênea. As variações na vegetação, topografia, solos e uso da terra são levados em conta ao invés de valores médios. Outra característica importante do CHDM é a simulação baseada em eventos.

- KINEROS 2 (KINEMATIC RUNOFF AND EROSION MODEL). É um modelo de evento orientado, cujos embasamentos físicos descrevem os processos de interceptação, infiltração, escorrimento superficial e erosão de bacias agrícolas e pequenas áreas urbanas. A bacia é representada por uma cascata de planos e canais. O modelo KINEROS pode ser usado para determinar os efeitos de várias características artificiais de infra-estruturas urbanas tais como pequenos reservatórios de detenção. O KINEROS usa equações cinemáticas unidimensionais para simular fluxo sobre planos retangulares através de canais trapezoidais, condutos circulares, canais abertos, canais circulares e pequenas lagoas.

- EUROSEM (European Soil Erosion Model). O modelo EUROSEM possui uma estrutura modular que simula o transporte de sedimentos pela água gerada por uma série de superfícies planas uniformes interligadas. Cada módulo representa um processo físico (interceptação, evaporação, etc) através de uma série de equações matemáticas. Este modelo exclusivamente simula eventos unitários de chuva durante tempos curtos (1 minuto) e é aplicado a escala de plots. Um dos problemas associados a modelos baseados na representação física é o elevado número de parâmetros e variáveis exigidas. 0 Eurosem requer um numero superior a 30 parâmetros para cada elemento espacial a ser modelado, alguns de difícil obtenção como a condutividade 
hidráulica do meio saturado. Outro problema é a escala temporal (minutos) adotada, o que exige um número significativo de informações climáticas.

- LISEN (Limburg Soil Erosion Model). O LISEM simula o transporte de sedimentos e os aspectos hidrológicos durante e imediatamente após um único evento de chuva em pequenas bacias. O modelo tem sido usado em bacias entre 10 a 300 ha. O LISEM é construído para simular os efeitos do uso do solo e medidas de conservação. Os processos básicos incorporados ao modelo são escorrimento superficial, interceptação, depósito em micro depressões, infiltração, movimento vertical de solo.Este modelo físico é totalmente integrado com um sistema de informações geográficas.

- AVSWAT (Arc-View Soil and Water Assessment Tool). O modelo AVSWAT (Soil and Water Assessment Tool), permite uma grande flexibilidade na configuração de bacias hidrográficas. O modelo foi desenvolvido para predizer o efeito de diferentes cenários de manejo na qualidade da água, produção de sedimentos e cargas de poluentes em bacia hidrográficas agrícolas. A maior limitação ao uso desses modelos é a dificuldade em trabalhar uma grande quantidade de dados que descrevem a heterogeneidade dos sistemas naturais. O modelo opera em passo de tempo diário e é capaz de simular longos períodos para computar os efeitos do manejo. O modelo é baseado em uma estrutura de comandos para propagar o escorrimento, sedimentos e agroquímicos através da bacia. Os maiores componentes do modelo incluem hidrologia, clima, sedimentos, temperatura do solo, crescimento de plantas, nutrientes, pesticidas e manejo agrícola. $O$ componente hidrológico do modelo inclui sub-rotinas do escorrimento superficial, percolação, fluxo lateral sub-superficial, fluxo de retorno do aqüífero raso e evapotranspiração. O modelo requer dados diários de precipitação, temperaturas máximas e mínima do ar, radiação solar, velocidade do vento e umidade relativa.

- SLURP (Semi-distributed Land Use-based Runoff Processes). O modelo SLURP é um modelo hidrológico semi-distribuído que simula os principais processos do ciclo hidrológico (evaporação, transpiração, infiltração, etc). O modelo divide a bacia em um número de unidades espaciais baseado na classificação do uso da terra e propriedades fisiográficas. Para cada unidade é simulado um balanço hídrico para estimar quantitativamente os 
elementos do ciclo hidrológico. Cada unidade é então inter-relacionada através do escorrimento superficial (runoff). O modelo tem sido aplicado para a determinação de diferentes componentes do ciclo hidrológico como evaporação do solo e transpiração.

- WEPP (Water Erosion Prediction Project). O modelo WEPP simula os processos que ocorrem em uma determinada área em função do estado atual do solo, cobertura vegetal, resíduos culturais e umidade. Trata-se de um modelo contínuo, de eventos múltiplos. O estado atual destas características determinam as respostas da área a um determinado evento hidrológico, sendo ele derivado de chuva, derretimento de neve ou irrigação. Para cada dia, as características do solo e da cobertura vegetal são atualizadas. Quando o evento da chuva ocorre, as características atuais do terreno determinam se haverá produção de escorrimento superficial. Se houver, o modelo determina desprendimento de partículas, transporte e deposição ao longo da encosta, em canais. O modelo não contempla, porém erosões em grandes voçorocas e cursos de água. Os componentes do modelo WEPP não incluem módulos para a estimativa de transporte de nutrientes ou elementos químicos. Este modelo tem até agora sido desenvolvido para a descrição física do transporte de sedimentos, incluindo todos os principais processos hidrológicos que explicam o fluxo de água em uma área agrícola.

- Impiero (Agricultural Soil Erosion Evaluation Model). É um modelo híbrido baseado em redes neurais desenvolvidos para prever a vulnerabilidade, redução da produtividade e estratégias ótimas de manejo para parcelas agrícolas. A deposição de material não é considerada, devido à complexidade do processo de erosão do solo e inter-relação dos parâmetros do tipo USLE escolhido como tradicional na análise e avaliação do solo e técnicas empíricas de modelagem avançada.Dentro desta mesma linha de softwares de simulação pode-se citar os modelos Model Quest e Model Expert.

- $\quad$ AGNPS (Agricultural Non-Point Pollution Source). O modelo AGNPS foi desenvolvido pelo Agriculture Research Service - ARS - do United States Departament of Agriculture - USDA, em cooperação com a Minnesota Pollution Control Agency - MCPA e a Soil Conservation Service - SCS, para obter estimativas de qualidade do escorrimento superficial com ênfase nos nutrientes, pesticidas e sedimentos. O objetivo do modelo é comparar os 
efeitos do controle de poluição através de praticas que são incorporadas dentro do manejo conservacionista do solo em bacias hidrográficas rurais. O AGNPS foi desenvolvido para análise e previsão de estimativas do escorrimento e qualidade da água em bacias de até 20.000 ha. O modelo executa suas funções através de uma cadeia de células que obedecem a um sistema matricial, onde são determinadas as condições de fluxo pela identificação das células por um conjunto de números ordenados seqüencialmente. Sua operação é realizada através de células de grade com resolução de 1,012 ha até 16,189 ha, subdivididas na bacia, permitindo analise em qualquer ponto. Cada célula representa homogeneamente os fatores ambientais dentro do limite de sua respectiva área, incluindo condições de relevo e canais; considera-se célula primária aquela na qual nenhuma outra direciona para seu interior estes componentes.

$\mathrm{Na}$ Tabela 10 são destacados alguns dos principais modelos encontrados na literatura. Os mais utilizados foram descritos acima.

Tabela 10. Alguns modelos utilizados para simulação de processos de erosão em bacias hidrográficas.

\begin{tabular}{|c|c|c|}
\hline MODELO(ABREVIATURA) & NOME & AUTOR E ANO \\
\hline USLE & Universal soil loss equation & Wischmeier and Smith (1978 \\
\hline ANSWERS & $\begin{array}{l}\text { Areal non-point source watershed } \\
\text { environmental response simulation }\end{array}$ & Beasley et al. (1980) \\
\hline EPIC & Erosion-productivity impact calculator & Williams (1985) \\
\hline AGNPS & Agricultural Non-Point Pollution Source & Young et al. (1987) \\
\hline CREAMS & $\begin{array}{c}\text { Chemicals, runoff and erosion from agricultural } \\
\text { management systems }\end{array}$ & Knisel (1991) \\
\hline WESP & Watershed Erosion Simulation Program & Lopes (1987) \\
\hline GLEAMS & $\begin{array}{c}\text { Groundwater loading effects of agricultural } \\
\text { management Systems }\end{array}$ & Knisel (1991) \\
\hline RUSLE & Revised universal soil loss equation & Renard et al. (1991) \\
\hline SWATT & Soil and Water Assessment Tool & Arnold et al. (1993) \\
\hline MIKE-SHE & & Refsgaard and Storm (1995) \\
\hline CHDM & Catchment Hydrology Distributed Model & Lopes $(1995)$ \\
\hline KINEROS2 & Kinematic runoff and erosion model & Smith et al. (1995) \\
\hline EUROSEM & European soil erosion model & Morgan et al. (1998) \\
\hline EROSION3D & 3D erosion model & Schmidt et al. (1999) \\
\hline LISEM & Limburg soil erosion model & Jetten and De Roo (2001) \\
\hline TOPMODEL & & Beven and Freer (2001) \\
\hline SLURP & $\begin{array}{l}\text { Semi-distributed Land Use-based Runoff } \\
\text { Processes }\end{array}$ & LACROIX et al (2002) \\
\hline WEPP & Water erosion prediction project & Flanagan et al. (2001) \\
\hline IMPIERO & Agricultural Soil Erosion Evaluation Model & Licznar \& Nearing (2003) \\
\hline
\end{tabular}




\section{MATERIAIS E MÉTODOS}

\subsection{Fases da pesquisa}

A Figura 7 ilustra os detalhes de todas as fases da pesquisa. A definição da pesquisa, na primeira fase, compreendeu uma grande discussão sobre a aplicabilidade e interesse no desenvolvimento de um tema ligado a poluição oriunda de bacias hidrográficas rurais.

A evolução e amadurecimento da escolha do tema da pesquisa deramse em função dos trabalhos desenvolvidos pelo grupo de pesquisa do Professor Doutor Reinaldo Lorandi, junto à Universidade Federal de São Carlos (UFSCAR) bem como dos trabalhos desenvolvidos pelo grupo de pesquisa do Professor Doutor Silvio Crestana junto à EMBRAPA Instrumentação Agropecuária e Universidade de São Paulo (USP).

Conciliado os interesses e definido a temática do trabalho da pesquisa, avançou-se para a segunda fase da pesquisa que consistiu, sinteticamente, na revisão bibliográfica; escolha do modelo matemático para a solução das perguntas do projeto inicial; aquisição de dados de entrada do modelo; correta entrada dos dados no modelo e simulações no modelo.

Finalmente, a última fase compreendeu a geração dos resultados numéricos, representados por tabelas, gráficos e imagens, bem como a interpretação dos mesmos, com finalidade de avaliação da microbacia em estudo e proposição de medidas mitigadoras à poluição. 


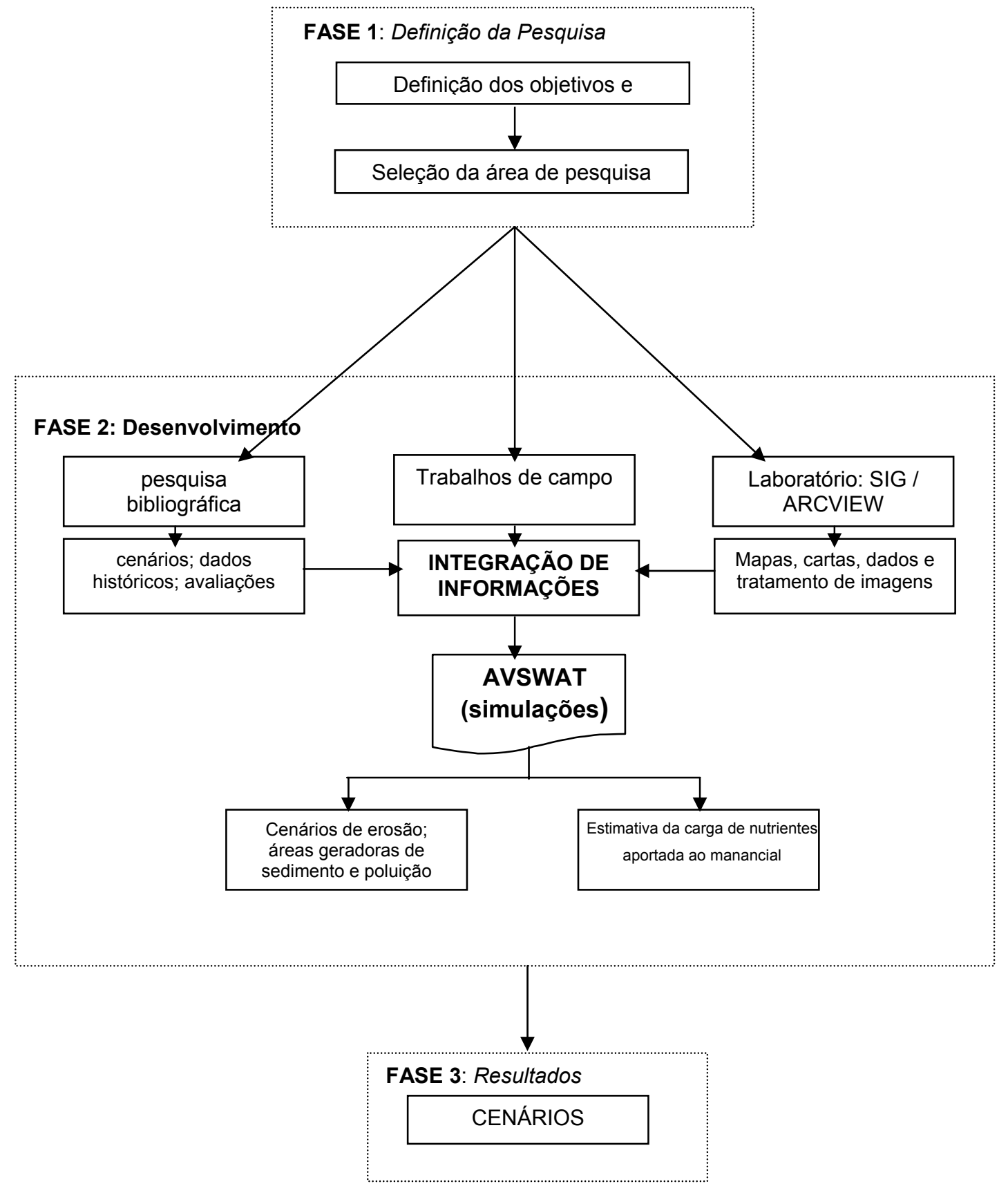

Figura 7. Fases da Pesquisa e etapas do trabalho. 


\subsection{A escolha da área de estudo}

A escolha do tema, inicialmente, teve forte influência dos trabalhos desenvolvidos pela Embrapa Suínos e Aves - Concórdia (SC).

A grande disponibilidade de publicações, pesquisas desenvolvidas pelas indústrias de processamento de carnes, consórcios de bacias hidrográficas e muitos outros projetos, despertou grande curiosidade para a situação e contextualização da atividade no Estado de São Paulo, em nível de bacia hidrográfica.

Balizados por uma revisão bibliográfica preliminar, os principais parâmetros da problemática sócio-político-ambiental foram então fixados.

Nesta fase, vale destacar, a literatura demonstrou claramente a presença de dois cenários distintos em relação à atividade pecuária (suínos e aves) no Brasil: o primeiro foi o processo de reestruturação da atividade na região Sul do País, com a presença marcante das conseqüências ambientais negativas, em fase/processo de mitigação; o outro cenário destaca-se principalmente na região Centro-Oeste, na qual a atividade está em franco desenvolvimento, com tecnologia apropriada e melhor estruturada no sentido de atender às demandas da atividade.

Como conseqüência do avanço das pesquisas bibliográficas, destacouse o problema da perda de solos por erosão, evento físico e altamente dinâmico, que tem comprometido sobremaneira a qualidade das águas no mundo.

Finalmente, fixaram-se parâmetros, na busca de uma determinada bacia hidrográfica, os quais estão expostos a seguir:

1. Existência de atividade pecuária (suínos e aves);

2. Confinamento de animais;

3. Manejo dos dejetos gerados;

4. Presença de solos altamente suscetíveis à erosão;

5. Região afetada pelo desflorestamento, agricultura e pecuária intensiva; 
6. Região de elevada importância econômica, social e ambiental;

7. Existência constatada ou presumida de poluição derivada da atividade;

8. Existência de estudos na região;

9. Interesse científico e tecnológico.

A busca pela área geográfica, palco da pesquisa em desenvolvimento, chegou ao fim com a eleição da microbacia hidrográfica do Rio Bonito, situada no município de Descalvado, Estado de São Paulo, pertencente a bacia do médio Mogi-guaçu.

De maneira notável, a microbacia hidrográfica reuniu todas as características elencadas como prioritárias, bem como está situada a $100 \mathrm{Km}$ do município de São Carlos (SP), fator importante, no âmbito econômico, para o desenvolvimento do projeto de pesquisa.

Outro elemento estimulante foi que há na bibliografia disponível, alguns trabalhos com preocupações similares, revestindo o presente estudo de um caráter contributivo para a discussão e compreensão dos problemas que afetam a microbacia do Rio Bonito.

\subsection{Caracterização da área}

\subsubsection{O município de Descalvado (SP)}

O município de Descalvado, fundado em 1.832, teve seu apogeu no fim do século XIX quando as terras do município foram invadidas pelos milhares de pés de café, rendendo a município o título de $3^{\circ}$. maior produtor do Estado. Para escoar a produção, chegou, em I.882, a Cia. Paulista de estradas de ferro, que teve fundamental papel no desenvolvimento da região.

Com o plantio de algodão no inicio de 1920, a industria têxtil passou a ser a atividade econômica principal do município. A avicultura teve início na década de 50 e na metade dos anos 70, desenvolvendo-se rapidamente, tornando o município um dos maiores produtores de frango de corte. 
Desde a década de 60, o município de Descalvado vem estruturando-se, espacialmente, em relação à produção avícola.

A partir desta década, desencadearam-se transformações com a implantação de muitas indústrias e estabelecimentos comerciais, especializados em produtos para a avicultura como ração e pintos de um dia, além de uma gama de empresas transportadoras de produtos. O setor avícola transformou profundamente o espaço e a organização territorial de Descalvado, até então marcado pelo plantio do café e pela cultura italiana.

A presença de uma conjuntura nacional e até mesmo internacional favorável, abre espaço para novas estratégias de integração às correntes múltiplas de comércio nacional e internacional de produtos agrícolas e agroindustriais, transformando radicalmente o quadro anterior aos anos 60, marcado pela estagnação das exportações e dependência de um único produto: o café.

Hoje, Descalvado conta com diversas atividades agropecuárias como, cana-de-açúcar, citricultura, milho, soja, café, pecuária leiteira, suinocultura, avicultura e atividades industriais, destacando-se: a mineral, de doces caseiros, de implementos avícolas e agrícolas, de metalurgia, de rações para avicultura e pecuária, cerâmicas artísticas e outras.

\subsubsection{Sócio-economia}

Em Descalvado, a população total do município está estimada em 28.972 habitantes, divididos em 24.190 urbanos e 4.782 rurais (IBGE, 2000).

As principais culturas do município são: cana de açúcar, café e laranja.

A cana-de-açúcar tem produtividade média de 82 toneladas por hectare $^{5}$, sendo destinada praticamente para industria sucro-alcooleira. Os tratos culturais não diferem muito entre as propriedades, pois são executados

\footnotetext{
${ }^{5}$ Informação do Plano da Microbacia Hidrográfica do alto rio Bonito.
} 
pelos arrendatários, com bom nível tecnológico. Apenas os produtores que possuem gado, em alguns casos, têm pequena área de cana-de-açúcar (baixa produção).

A citricultura é bastante importante e faz parte do Mercado Central do Estado de São Paulo.

Em relação à estrutura fundiária do município, predominam a pequena e média propriedade, conforme demonstrado pela tabela 11.

Tabela 11. Características do produtor e condição de uso da propriedade na microbacia hidrográfica do alto rio Bonito.

\begin{tabular}{|c|c|c|c|c|c|c|}
\hline & & \multirow{4}{*}{\begin{tabular}{c}
$*$ \\
\multirow{2}{*}{$\begin{array}{c}\text { Classificação } \\
\text { do produtor }\end{array}$}
\end{tabular}} & Quantidade & Percentual & \multicolumn{4}{|c|}{ Condição de uso } \\
\cline { 4 - 7 } & & & Proprietário & \multicolumn{2}{|c|}{ Arrendatário } \\
\cline { 4 - 7 } & & & Quant. & $\%$ & Quant. & $\%$ \\
\hline Pequeno & 25 & $40 \%$ & 25 & 42 & 0 & 0 \\
\hline Médio & 16 & $25 \%$ & 16 & 27 & 0 & 0 \\
\hline Grande & 22 & $35 \%$ & 18 & 31 & 7 & 100 \\
\hline
\end{tabular}

Fonte: Plano da Microbacia Hidrográfica do alto rio Bonito

Dados do IBGE (2002) evidenciam ainda que do total de propriedades, $61 \%$ possuem de 0 a 4 empregados, configurando exploração familiar (tabela 12).

As culturas de milho e hortaliças são cultivadas em pequenas áreas, para consumo na propriedade, sendo o excedente vendido dentro do município. 
Tabela 12. Número de empregados em estabelecimentos rurais de Descalvado (SP)

\begin{tabular}{|c|c|}
\hline Número de empregados & Número de estabelecimentos \\
\hline Sem pessoal & 11 \\
\hline 1 a 4 & 9 \\
\hline 5 a 9 & 1 \\
\hline 10 a 19 & 5 \\
\hline 20 a 29 & 1 \\
\hline 30 a 49 & 3 \\
\hline 50 a 99 & 1 \\
\hline 100 ou mais & 2 \\
\hline
\end{tabular}

Fonte: IBGE- Pesquisa Pecuária Descalvado 2002

Em relação à pecuária, a microbacia do rio Bonito apresenta as seguintes características, demonstradas pela tabela 13 (IBGE, 2002).

Tabela 13. Características da pecuária em Descalvado (SP)

\begin{tabular}{|l|r|r|}
\hline \multicolumn{1}{|c|}{ Descrição } & \multicolumn{1}{c|}{ Valor } & Unidade \\
\hline Efetivo dos rebanhos - bovinos & 30850 & cabeça \\
\hline Efetivo dos rebanhos - porcas criadeiras & 500 & cabeça \\
\hline Efetivo dos rebanhos - outros porcos e porcas & $\mathbf{4 5 0 0}$ & cabeça \\
\hline Efetivo dos rebanhos - galinhas & 229300 & cabeça \\
\hline Efetivo dos rebanhos - galos, frangas, frangos e pintos & $\mathbf{5 0 0 0 0 0 0}$ & cabeça \\
\hline Efetivo dos rebanhos - eqüinos & 1100 & cabeça \\
\hline Efetivo dos rebanhos - asininos & 10 & cabeça \\
\hline Efetivo dos rebanhos - muares & 150 & cabeça \\
\hline Efetivo dos rebanhos - caprinos & 80 & cabeça \\
\hline Efetivo dos rebanhos - ovinos & 200 & cabeça \\
\hline Leite de vaca - produção - vacas ordenhadas & 7400 & cabeça \\
\hline Leite de vaca - produção - quantidade (mil litros) & 19000 & litro \\
\hline Leite de vaca - produção - valor (reais) & 5700000 & reais \\
\hline Ovos de galinha - produção - quantidade (mil dúzias) & 2752 & dúzia \\
\hline Ovos de galinha - produção - valor (reais) & 963200 & reais \\
\hline
\end{tabular}

Fonte: IBGE- Pesquisa Pecuária Descalvado 2002 
O relatório do $\mathrm{PMH}$ do alto rio Bonito informa que a pecuária de leite é importante como atividade econômica para os pequenos e médios produtores, pois complementa a renda mensal. No entanto, afetada pela conjuntura econômica atual, esta atividade tem-se mostrado de baixa rentabilidade, fator agravado pela crise mundial da indústria italiana Parmalat.

$\mathrm{Na}$ exploração de bovinocultura de corte a produtividade é baixa, pois são animais mestiços oriundos da pecuária leiteira e que são engordados em pastos de baixo valor nutricional.

A Avicultura (Figura 8) é uma atividade importante, pois demanda mãode-obra em seus vários segmentos produtivos (granjas, fábrica de rações, abatedouro e cooperativas). A maioria dos avicultores trabalha integrada com a cooperativa ou empresas de rações, sendo as aves abatidas nos abatedouros de Descalvado e região e posteriormente comercializadas nos grandes centros urbanos.

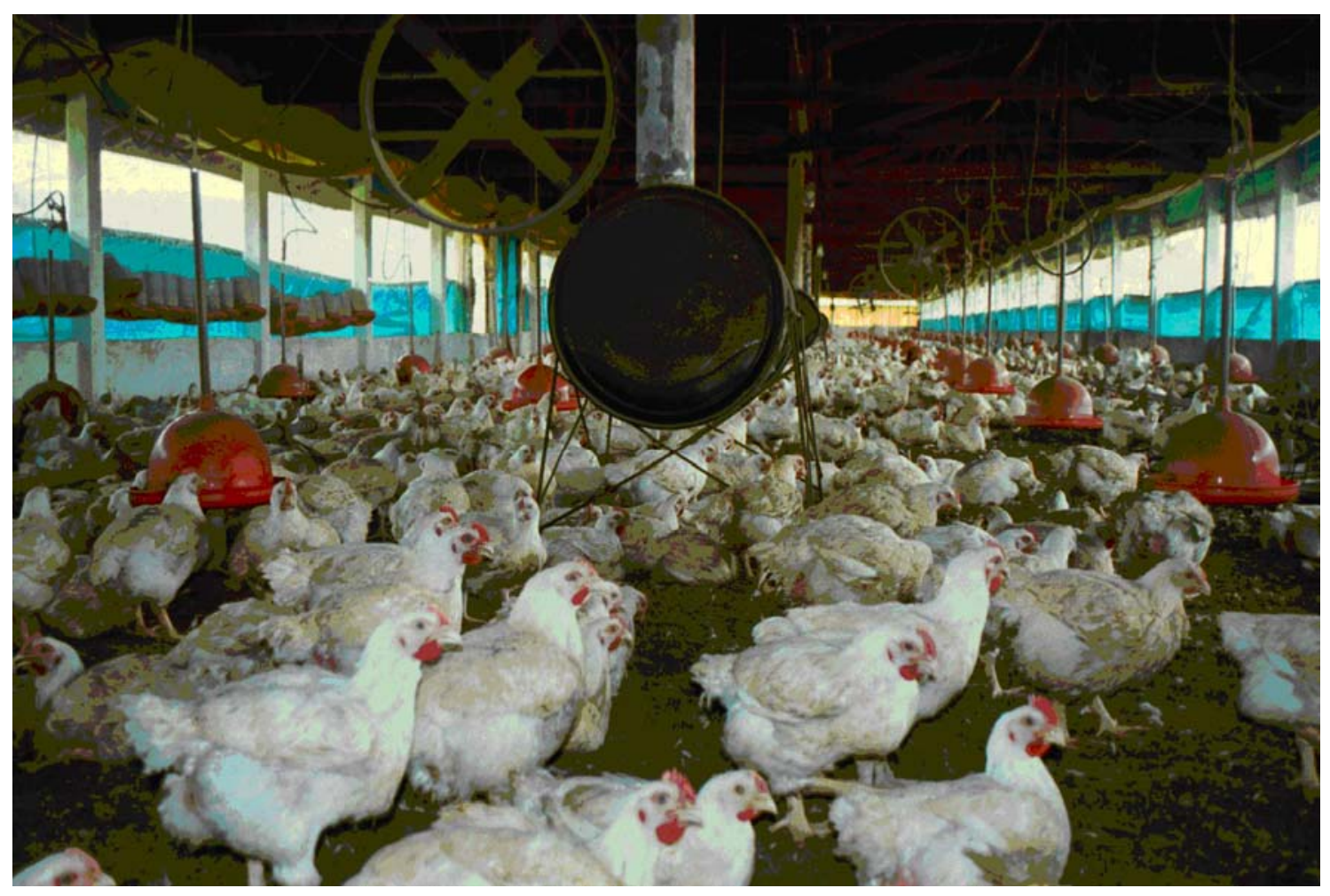

Figura 8. Avicultura na microbacia do rio Bonito. Descalvado (SP).

Fonte: Foto do Autor, Janeiro/2004 
Em relação à suinocultura (Figura 9), está presente nas pequenas propriedades, não expressando grande representatividade na economia total da bacia hidrográfica. O plantel está representado por 5 mil cabeças (IBGE, 2002), tendo sido, no entanto, relatado no $\mathrm{PMH}$ alto rio Bonito o número de 7 mil cabeças.

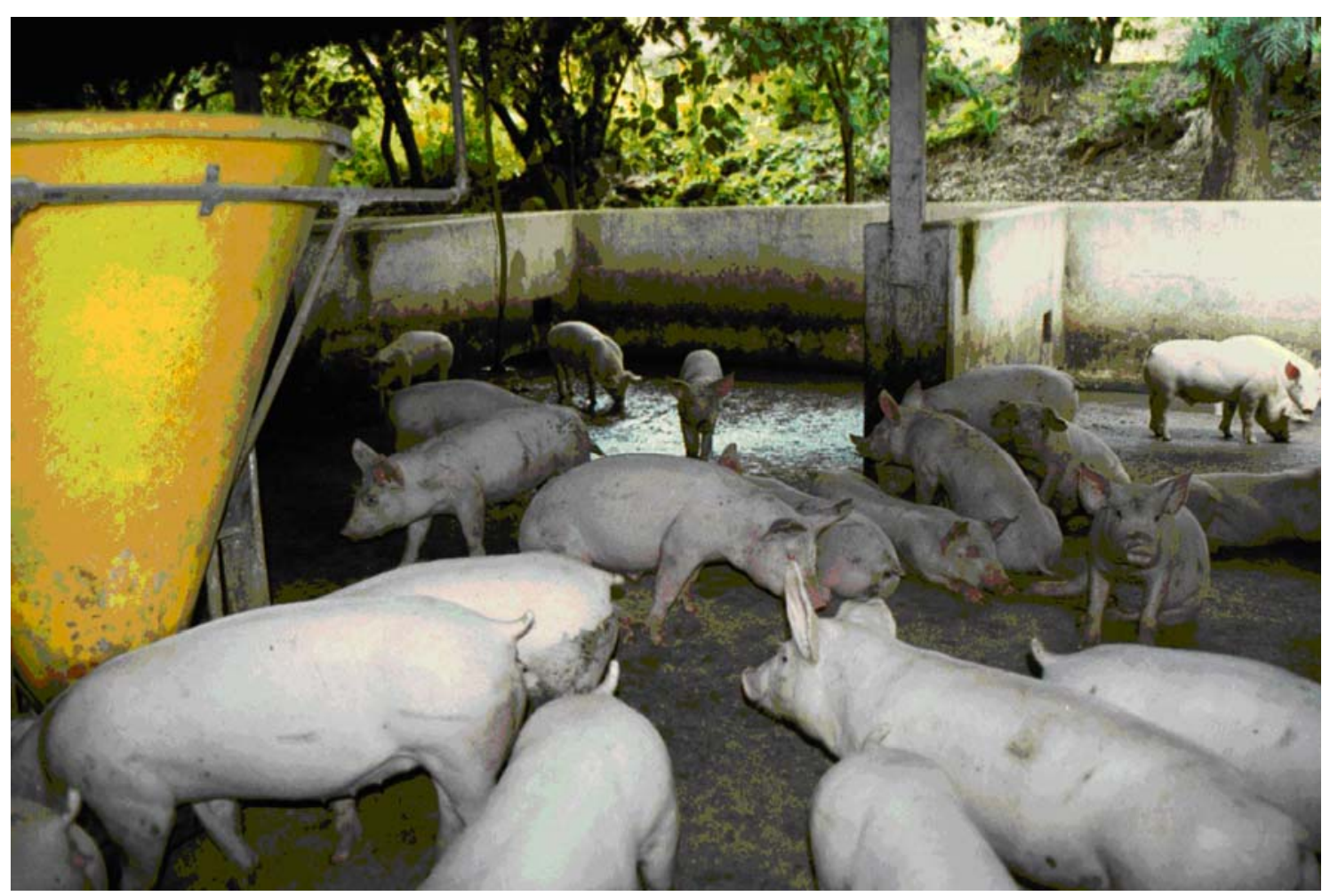

Figura 9. Suinocultura na microbacia do rio Bonito. Descalvado (SP).

Fonte: Foto do Autor, Janeiro/2004.

\subsubsection{Clima}

Descreveu FONSECA (2002), que o clima da região pode ser considerado, de acordo com o sistema internacional de Köeppen, com sendo do tipo Cwa, ou seja, mesotérmico de inverno seco, onde as temperaturas médias anuais variam entre 18 e $22^{\circ} \mathrm{C}$. As figuras 10 e 11 destacam os índices pluviométricos médios e o balanço hídrico mensal normal. 


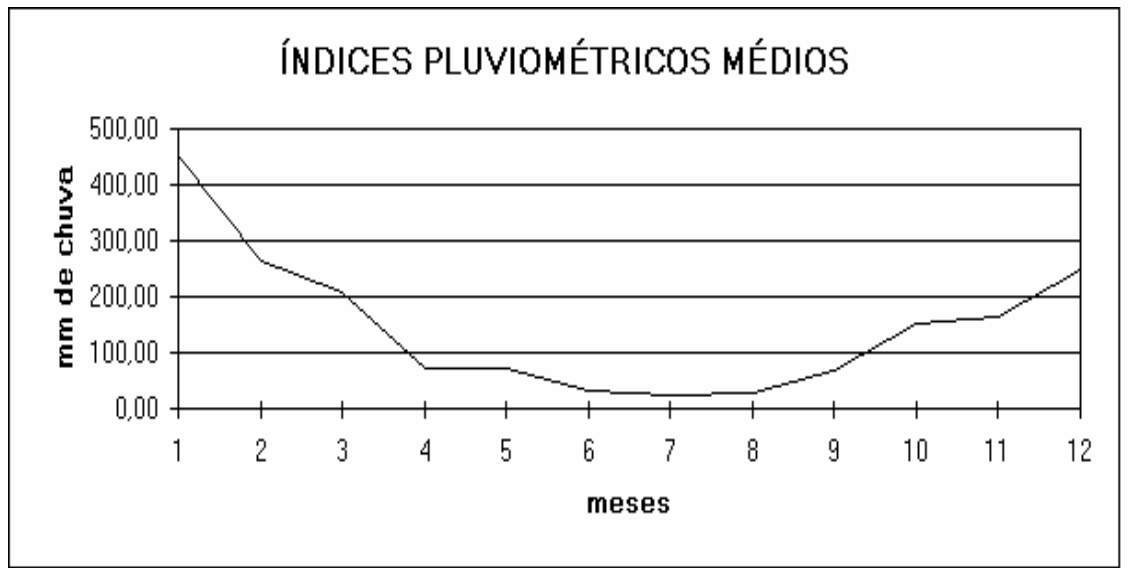

Figura 10. Índices pluviométricos médios do período de 1990 a 2002. Descalvado (SP). Fonte: Plano da Microbacia Hidrográfica do alto rio Bonito ${ }^{6}$

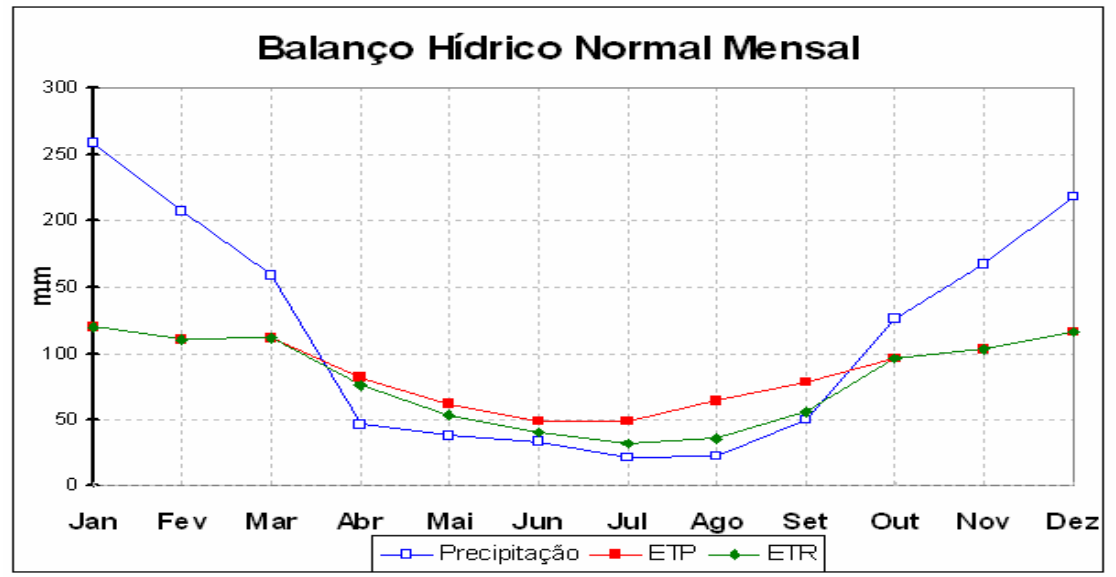

Figura 11. Balanço hídrico mensal. Descalvado (SP)

Fonte: CIIAGRO - Centro Integrado de Informações Agrometeorológicas.

\subsubsection{Solos}

A área de interesse é composta por 7 unidades diferentes de solo: gleissolos $(3 \%)$, neossolos litólicos $(3 \%)$, argissolos $(5 \%)$, latossolo vermelho

6 Plano da Microbacia Hidrográfica do alto rio Bonito. Secretaria de Agricultura e Abastecimento. Coordenadoria de Assistência Técnica Integral - CATI. Programa Estadual de Microbacias Hidrográficas. Responsáveis: Engs. Agrs. José Wilson Baião e José Carlos Paggiaro. 
mesoférrico mesoférrico (8\%), latossolo vermelho eutroférrico (13\%), neossolos quartzarênicos (23\%) e latossolo amarelo (45\%) (modificado de FONSECA, 2002).

Os diferentes solos da microbacia são descritos a seguir:

- Gleissolos: são solos intrazonais, nos quais as características equivalentes dos solos zonais não se desenvolveram, em grande parte devido à grande influência da água no perfil. Essa influência da água está condicionada principalmente pelo relevo. O encharcamento desse tipo de solo pode ocasionar um acúmulo de matéria orgânica ou fenômeno da gleização, provocado pela redução e solubilização dos compostos de ferro, e que é evidenciado pela cor cinzenta e por mosqueamentos.

- Neossolos Litólicos: são solos muito rasos, pouco desenvolvidos, constituídos pelo horizonte superficial, de pequena espessura, formados pela acumulação de matéria orgânica, seguido de rocha pouco alterada, consolidada ou semibranda.

- Argissolos: são solos bem drenados, com seqüência de horizontes A-E-B-C, com nítida diferenciação entre eles e o teor de argila do horizonte B é bem mais elevado que os horizontes superficiais. São ácidos e com saturação de bases baixas.

- Latossolo vermelho mesoférrico mesoférrico: são solos bem drenados, com seqüência de horizontes $A-B-C$, pequena diferenciação entre eles. Possuem coloração vermelho-escura, ácidos, com saturação de base baixa e com teores de óxido de ferro intermediários entre o latossolo vermelho mesoférrico eutroférrico e o latossolo amarelo.

- Latossolo vermelho mesoférrico eutroférrico: são solos bem drenados, com seqüência de horizontes A-B-C e pequena diferenciação entre eles. Apresentam coloração vermelho-arroxeada, bastante porosos e profundos, com pequena variação de cor entre os horizontes. Sua saturação é de base 
variável, sendo que a fertilidade natural pode ser alta ou baixa. Os teores de óxido de ferro e manganês são altos. O material de origem desses solos são rochas eruptivas básicas e o relevo varia de ondulado a suave ondulado e a vegetação original é a floresta, ocorrendo em algumas áreas o cerrado quando a fertilidade natural é muito baixa.

- Neossolos quartzarênicos: são solos pouco desenvolvidos e constituídos de um horizonte $A$ assentado sobre um horizonte $C$, profundo e arenoso. $O$ material de origem é arenito. O relevo é suave, ondulado e a vegetação é do tipo cerrado.

- Latossolos amarelo: são solos bem drenados, com seqüência de horizontes A-B-C, pequena diferenciação entre horizontes, relação textural (\% de argila do horizonte B / \% de argila do horizonte A) em torno de 1,3, de coloração amarela até vermelha, ácidos, com saturação de bases baixa e baixos teores de óxidos de ferro.

\subsubsection{Geologia}

As unidades geológicas, que formam a bacia do rio Bonito, foram compiladas por Torezan, 2000, conforme segue:

- Formação Santa Rita: 55\%

- Formação Pirassununga: $17 \%$

- Formação Serra Geral: $13 \%$

- Formação Pirambóia: 5\%

- Depósitos Recentes: 4\%

- Formação Corumbataí: 3\%

- Formação Botucatu: $2 \%$

- Formação Itaqueri: $1 \%$

Formação Santa Rita do Passa-Quatro (? Terciário): areias e cascalhos. Depósitos arenosos de idade terci-quaternária, com origens extremamente diversas (marinhos, fluviais ou elúvio-coluvionares); 
Formação Pirassununga (? Terciário): constituída por sedimentos arenosos inconsolidados, não estratificados e sem estrutura, verticalmente homogêneos, sobrepostos indiferentemente às formações mais antigas, em cuja base têm sido encontradas, por vezes, linhas de seixos subangulares e arredondados, de formas variadas, ou cascalheiras de espessura centimétrica, ambas compostas por seixos de quartzo, quartzito e limonitas (concreções). Sua espessura não ultrapassa vinte metros e dispõe-se de modo descontínuo na folha de Leme. A coloração predominante desses sedimentos é marron-avermelhada, com baixo grau de seleção, contendo minerais argilosos, grãos de quartzo com vários índices de arredondamento, às vezes com película de óxido de ferro secundário e minerais máficos;

Formação Serra Geral (Jura-Cretáceo): essa formação compreende o conjunto de derrames de lavas basálticas, toleíticas, de textura afanítica e de cor cinza escura a preta e intrusivas associadas (diques e soleiras) bastante comuns na área, contendo intercalações de lentes e camadas arenosas, de textura fina a média, com estratificação cruzada, que capeiam as formações gonduânicas da bacia do Paraná. A espessura máxima dos derrames inferiores é de aproximadamente 100 metros, medida a oeste de Descalvado, mas com um valor médio de 40 metros e um máximo de 400 metros na serra de Botucatu.

Formação Pirambóia: (Triássico): constitui-se de arenitos esbranquiçados, amarelados, avermelhados e róseos, médios a muito finos, ocasionalmente grosseiros, regularmente classificados, síltico-argilosos, quartzosos, com grãos subarredondados e intercalações de siltitos e argilitos. Mais raramente, observam-se ainda arenitos conglomeráticos, com seixos de quartzo e também de argila, com matriz areno-argilosa. Na seção inferior os arenitos tornam-se finos, predominando fácies bastante argilosa. Apresentam acamamento planoparalelo e estratificação cruzada do tipo planar, menos comumente acanalada, de pequeno e médio porte. Essa formação atinge uma espessura máxima de 260 metros, próximo à cidade de São Pedro, tendendo a diminuir em direção ao norte, apresentando amplo domínio distributivo na área em estudo; 
Depósitos recentes (Quaternário): composta de planícies aluvionares bem desenvolvidas e que ocorrem ao longo dos rios Moji-Guaçu, Bonito e Claro e em parte dos cursos d'água de menor expressão da Quadrícula de Descalvado (SP). Esses depósitos, de várzeas e terraços, são constituídos de areias, argilas e cascalhos;

Formação Corumbataí (Permiano): essa formação é constituída, na sua seção inferior, de um pacote de argilitos, folhelhos e siltitos, com fraturas concoidais e concreções calcíferas e ainda um conjunto de argilitos e folhelhos cinza escuros, de aspecto rítmico, com ocasionais leitos de calcário silicificado, oolítico, além de níveis coquinóides. Na seção superior da formação, ocorre uma seqüência de argilitos e arenitos finos, argilosos, regular a bem classificados, esverdeados, arroxeados e avermelhados. Apresenta uma espessura de cerca de 180 metros nas proximidades da cidade de Charqueada e distribui-se espacialmente numa direção aproximadamente norte-nordeste, que se prolonga desde o sudeste de Laras até nordeste de Santa Rosa do Viterbo.

Formação Botucatu: (Jura-Cretáceo): é constituída por arenitos róseos, avermelhados e esbranquiçados, finos a médios; e também muito finos, regularmente a bem classificados, friáveis a bem silicificados, com grãos arredondados e foscos, apresentando na base corpos de arenitos conglomeráticos e conglomerados. Essa formação apresenta espessura bastante variável, mas raramente ultrapassa os 150 metros, sendo o valor médio da ordem de 50 a 70 metros.

Formação Itaqueri (Cretáceo/Terciário): essa formação ocorre em mancha irregular no reverso da cuesta basáltica, isolada de outras coberturas póstrapianas, representando suas partes mais elevadas testemunhos da antiga extensão do Planalto Ocidental. Sua espessura máxima observada é de 125 metros e é litologicamente constituída por membros alternados de arenitos com cimento argiloso, folhelhos e conglomerados ferríferos ou não. Ocorre predominância dos arenitos, sendo que os demais depósitos de extensão limitada, geralmente na forma lenticular alongada. 


\subsubsection{Dados geográficos}

A microbacia do Rio Bonito estende-se por uma área de $223 \mathrm{Km}^{2}$ entre os municípios de Descalvado $\left(200 \mathrm{Km}^{2}\right)$ e Porto Ferreira $\left(23 \mathrm{Km}^{2}\right)$, região centro-leste do Estado de São Paulo e é delimitada pelas coordenadas (em UTM) de 226200 a 244000 e de 7558000 a 7584000 (Figura 12).

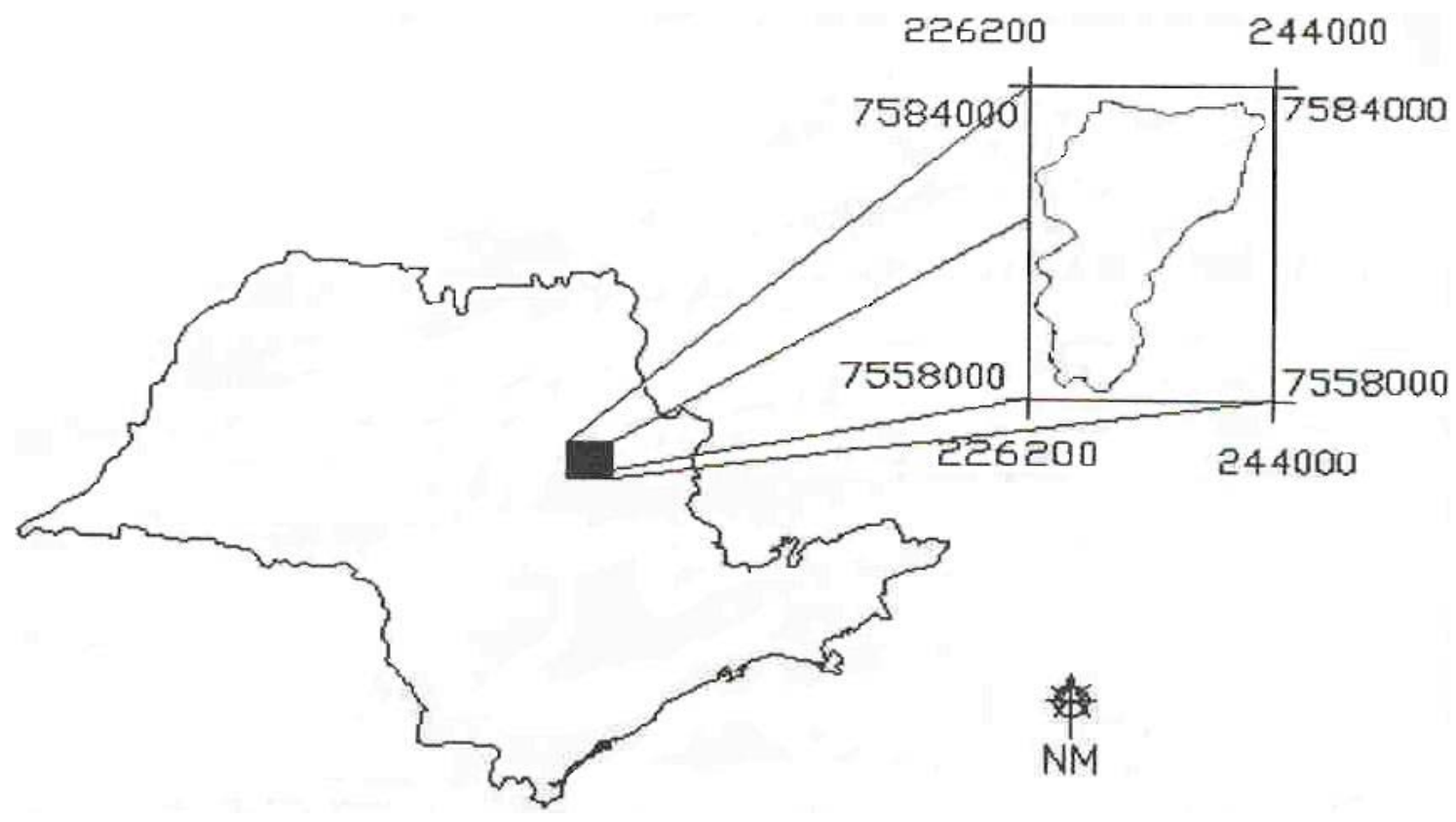

Figura 12. Localização geográfica da Microbacia Hidrográfica do Rio Bonito.

Fonte: Fonseca (2002).

\subsubsection{Hidrografia}

Segundo Fonseca (2002), o Rio Bonito, tem extensão de 38,5 Km. Está inserido na APA (Área de Preservação Ambiental) de Descalvado (SP), conforme demonstra a Figura $13^{7}$, no destaque tracejado.

\footnotetext{
${ }^{7}$ Mapa de Hidrografia da Área de Proteção Ambiental de Descalvado (SP). Heloisa Helena de Oliveira. IB/USP. 1994.
} 
Seus principais afluentes são o córrego da Vila Nova, córrego da Bomba, córrego da Serrinha, córrego do Rosário, córrego do Cateto, córrego Santo Antônio, córrego Paiolzinho ou da Olaria, córrego da Capetinga e ribeirão Areia Branca.

Também está evidenciado pelo PBH Alto Ribeirão Bonito que o córrego da Serrinha, com uma extensão de $6 \mathrm{~km}$, possui menor grau de assoreamento e poluição que o Ribeirão Bonito onde se desemboca, sendo também utilizado como fonte de água para animais e pontos de descarga de esgotos. Em relação ao córrego da Bomba, este possui $5.5 \mathrm{~km}$ de extensão, estando com problemas de assoreamento e menor grau de poluição por esgotos, em relação ao rio Bonito. O córrego Vila Nova, medindo $6.0 \mathrm{~km}$, apresenta pouca mata ciliar e assoreamento acentuado, sendo suas águas utilizadas para dessedentação de animais e irrigação. Possui problemas em relação à poluição.

O rio Bonito também apresenta sérios problemas de assoreamento e poluição, interferindo negativamente nas atividades econômicas, sociais e ambientais (PMH alto rio Bonito). As causas são: a falta de conservação do solo, práticas agrícolas inadequadas, destruição da mata ciliar e a atividade de mineração, além de poluição por resíduos orgânicos de residências e de animais que são lançados em suas águas. 


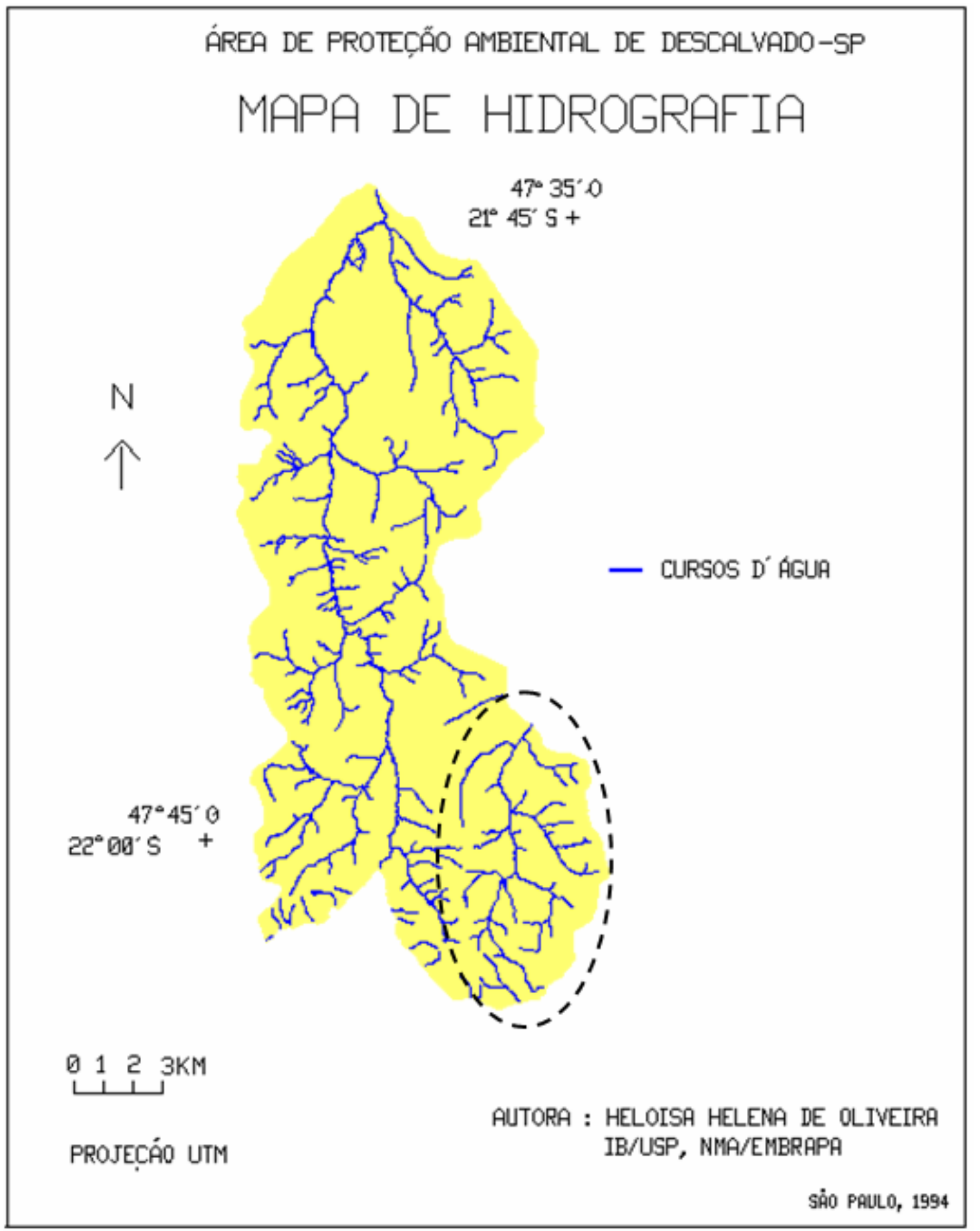

Figura 13. Hidrografia da APA de Descalvado (SP).

Fonte: Heloisa Helena de Oliveira. IB/USP. (1994). 


\subsubsection{Vegetação}

Oliveira (1995) apud Torezan (2000), identificou e classificou as formações vegetais remanescentes na área da APA de Descalvado, sendo as principais o cerrado, a mata mesófila e a mata ciliar.

Torezan (2000) em levantamento de campo realizado na área da bacia do rio Bonito, verificou que as formações vegetais correspondem àquelas indicadas por Oliveira (1995), uma vez que ambas são áreas vizinhas.

\subsubsection{Fauna}

Oliveira (1995) apud Torezan (2000), descreve que as áreas da bacia do rio Bonito abrigam espécies de animais raras na região, como o lobo guará (Chrysocyon brachyurus), urubu-rei (Sarcoramphus papa), veado mateiro (Mazama americana) e sauá (Callicebus personatus), entre outros.

\subsubsection{Uso e ocupação do solo}

Torezan (2000) descreve o uso dos solos da microbacia hidrográfica do rio Bonito da seguinte maneira: pastagem (28\%), cana-de-açúcar (30\%), mata $(11 \%)$, laranja $(8 \%)$, cerrado $(6 \%)$, cerradão $(5 \%)$, reflorestamento $(4 \%)$, outras culturas $(4 \%)$, área urbana $(3 \%)$ e mineração $(1 \%)$.

O tipo de uso predominante na bacia é a cultura de cana-de-açúcar, seguido de pastagens. As parcelas descritas como "solo exposto" e "solo semiexposto", são, na realidade, áreas em preparação para plantio de cana, conforme descreve Torezan (2000).

Fonseca (2002), descreve que, para as principais culturas da microbacia, os agrotóxicos mais utilizados são os evidenciados na Tabela 14.

Peculiar na bacia hidrográfica, talvez devido à sua pequena extensão, $223 \mathrm{Km}^{2}$ (TOREZAN, 2000), a avicultura e suinocultura dispõem-se de maneira 
concentrada em determinadas regiões. Observam-se concentrações de granjas de aves e, em determinadas regiões, avicultura e suinocultura muito próximas, elevando o risco de poluição ambiental. A Figura 14 representa esta ocorrência. $O$ ponto $A$ indica granjas de aves. $O$ ponto $B$ indica uma granja de suínos. $O$ ponto $C$ indica uma piscicultura.

Tabela 14. Agrotóxicos usados na região do Rio Bonito - Descalvado (SP)

\begin{tabular}{|c|l|}
\hline PRINCIPAIS CULTURAS & \multicolumn{1}{|c|}{ NOME TÉCNICO } \\
\hline Laranja & Óxido de fembutalina, Propargita e Acrinatrin \\
\hline Cana & Diuron + Hexazinone, Ametrina e Hexazinona \\
\hline Hortaliças & Deltametrina, Metamidofos e Paration metílico \\
\hline Feijão & Mancozeb, Benomil e Thiofanato metílico \\
\hline Milho & Atrazine e $2,4-\mathrm{D}$ \\
\hline
\end{tabular}

Fonte: Fonseca (2002).

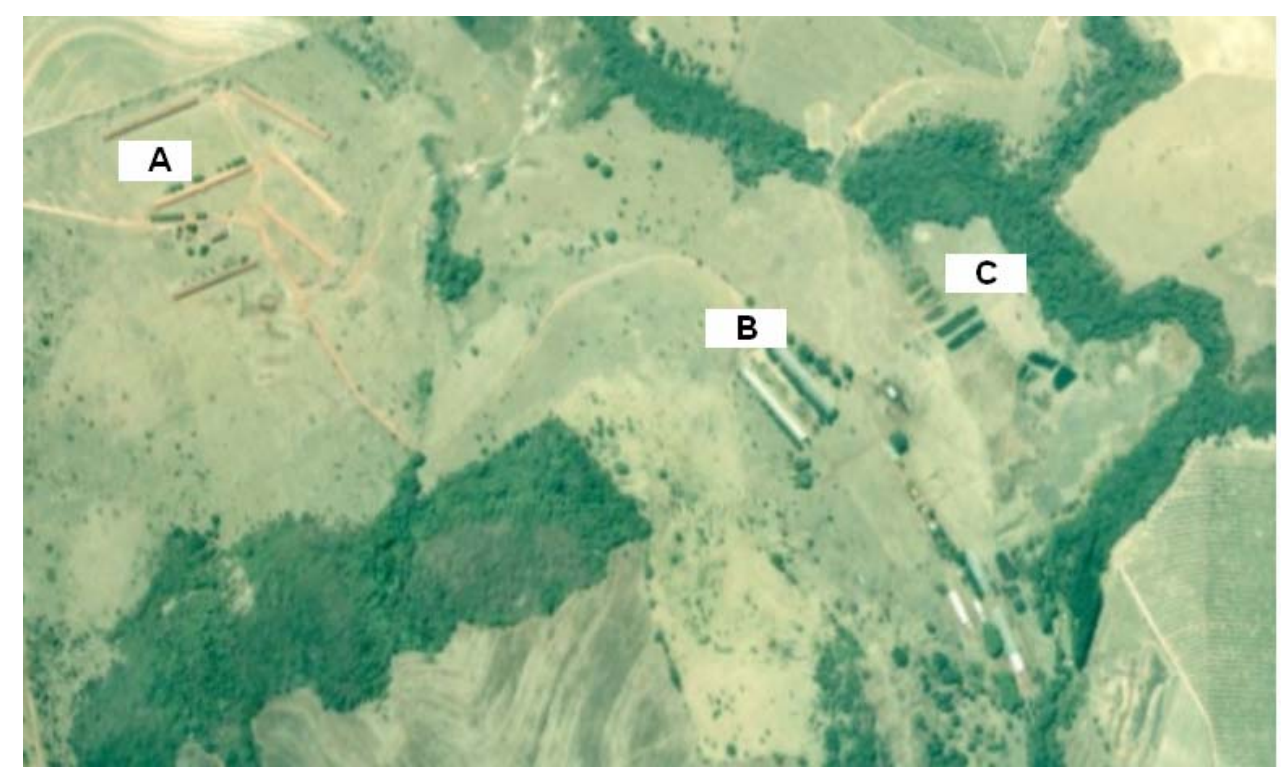

Figura 14. Concentração de atividades na microbacia do rio Bonito. Descalvado (SP). Fonte: Casa da Agricultura e Meio Ambiente de Descalvado. 


\subsubsection{Erosão na microbacia}

Dentre as várias formas de erosão, estão presentes na microbacia três tipos de erosão hídrica, descritas por Pruski (1997) e Feres (2002):

- Erosão laminar: caracteriza-se pela remoção de delgadas camadas da superfície do solo (Figura15);

- Erosão em sulcos: é facilmente perceptível devido à formação de valas e sulcos irregulares, formados em virtude da concentração do escorrimento superficial (Figura 16);

- Erosão em voçorocas: consiste no deslocamento de grande quantidade de solo, de modo a formar canais de grandes dimensões que impedem o trânsito de máquinas agrícolas e reduzem a área para o plantio (Figura 17).

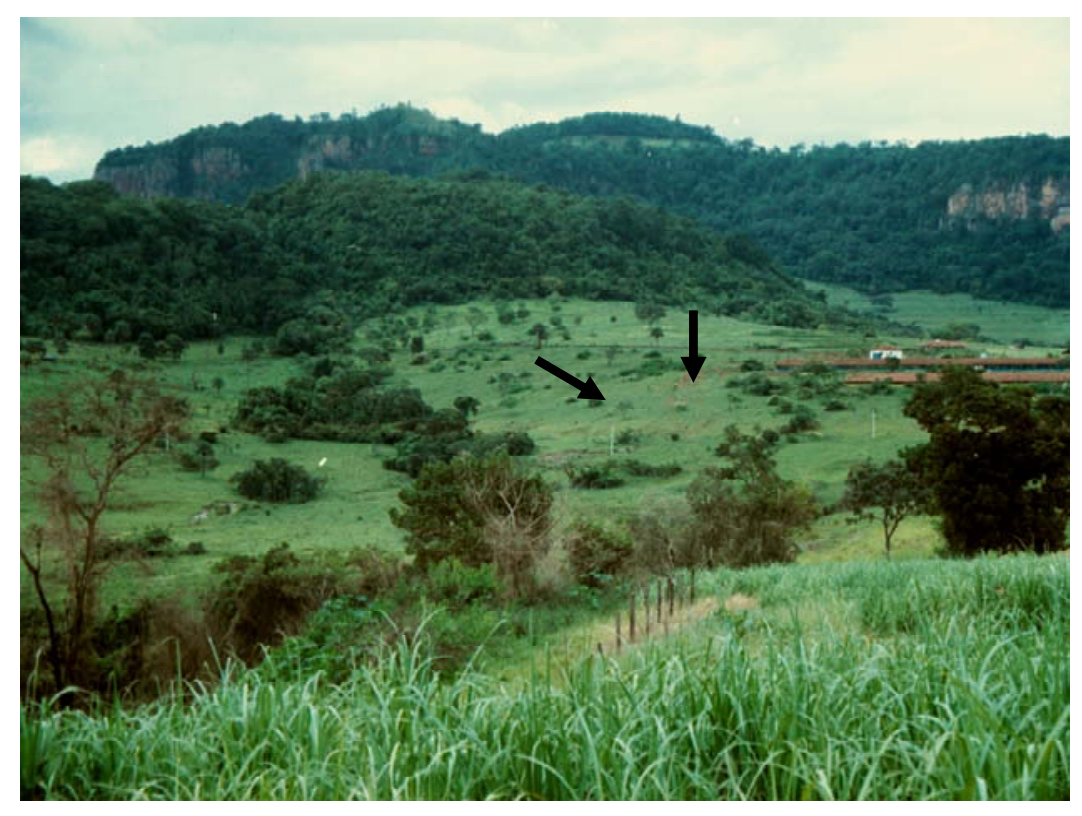

Figura 15. Evidências de erosão laminar na Microbacia Hidrográfica do Rio Bonito. Fonte: Foto do autor, Janeiro/2004 


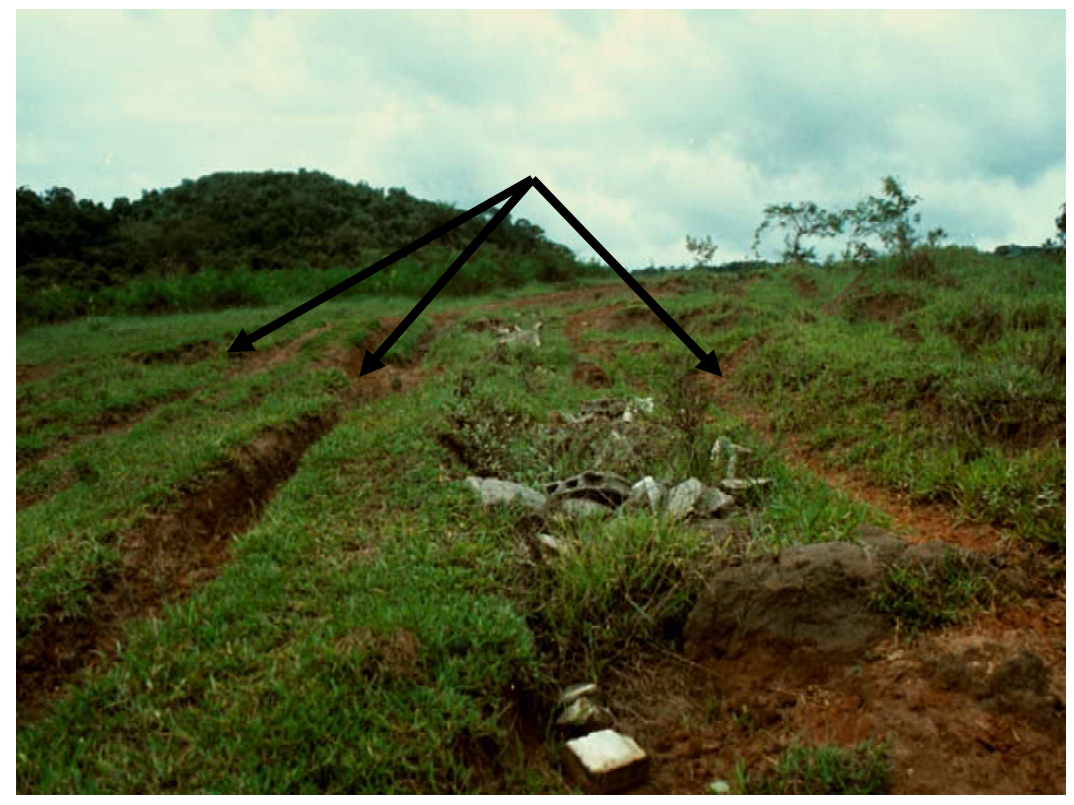

Figura 16. Evidências de erosão em sulcos na Microbacia Hidrográfica do Rio Bonito. Fonte: Foto do autor, Janeiro/2004

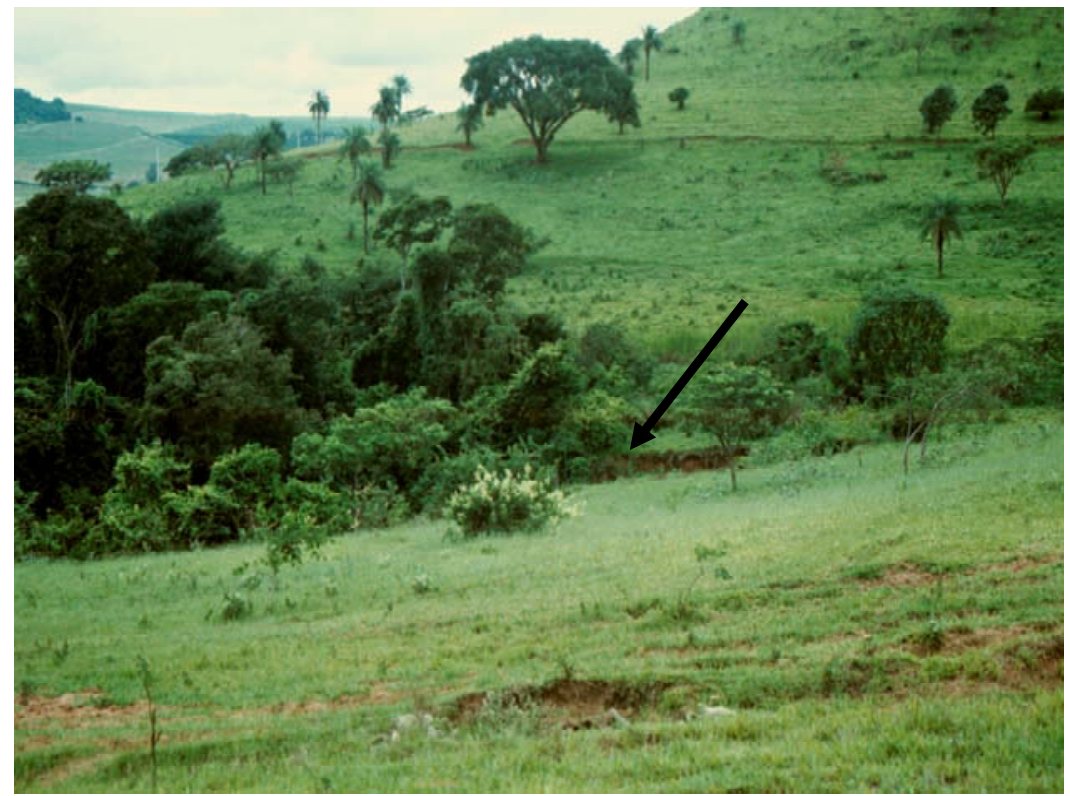

Figura 17. Evidência de voçoroca na Microbacia Hidrográfica do Rio Bonito.

Fonte: Foto do autor, Janeiro/2004 
Para Ranieri (2000), a suscetibilidade à erosão do solo do município de Descalvado pode ser dividida em baixa $(28,72 \%)$, média $(25,04 \%)$, alta $(26,84 \%)$, muito alta $(13,94 \%)$ e não suscetível $(4,82 \%)$ (Figura 18$)$.

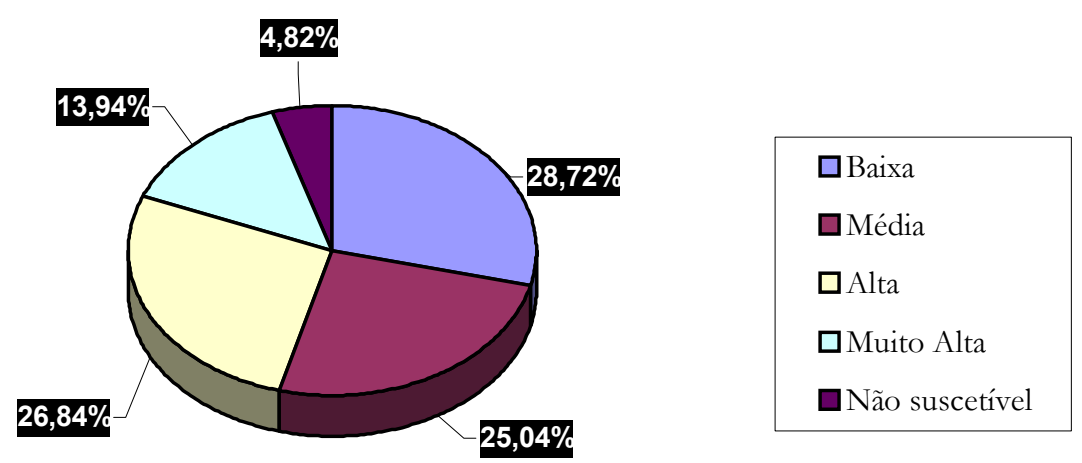

Figura 18. Suscetibilidade à erosão do solo de Descalvado (SP).

Torezan (2000), ao detalhar as áreas de risco potencial à erosão, da microbacia hidrográfico do Rio Bonito, Figura 19, destaca regiões onde o impacto de eventos antrópicos podem potencializar os eventos erosivos. Destaca ainda que atividades impactantes, como mineração, podem afetar a qualidade das águas superficiais e subterrânea por meio da contaminação com material dissolvido e particulado.

Nota-se, ao analisar a Figura 19, uma grande área enquadrando-se nas categorias de alta e muito alta suscetibilidades à erosão. 


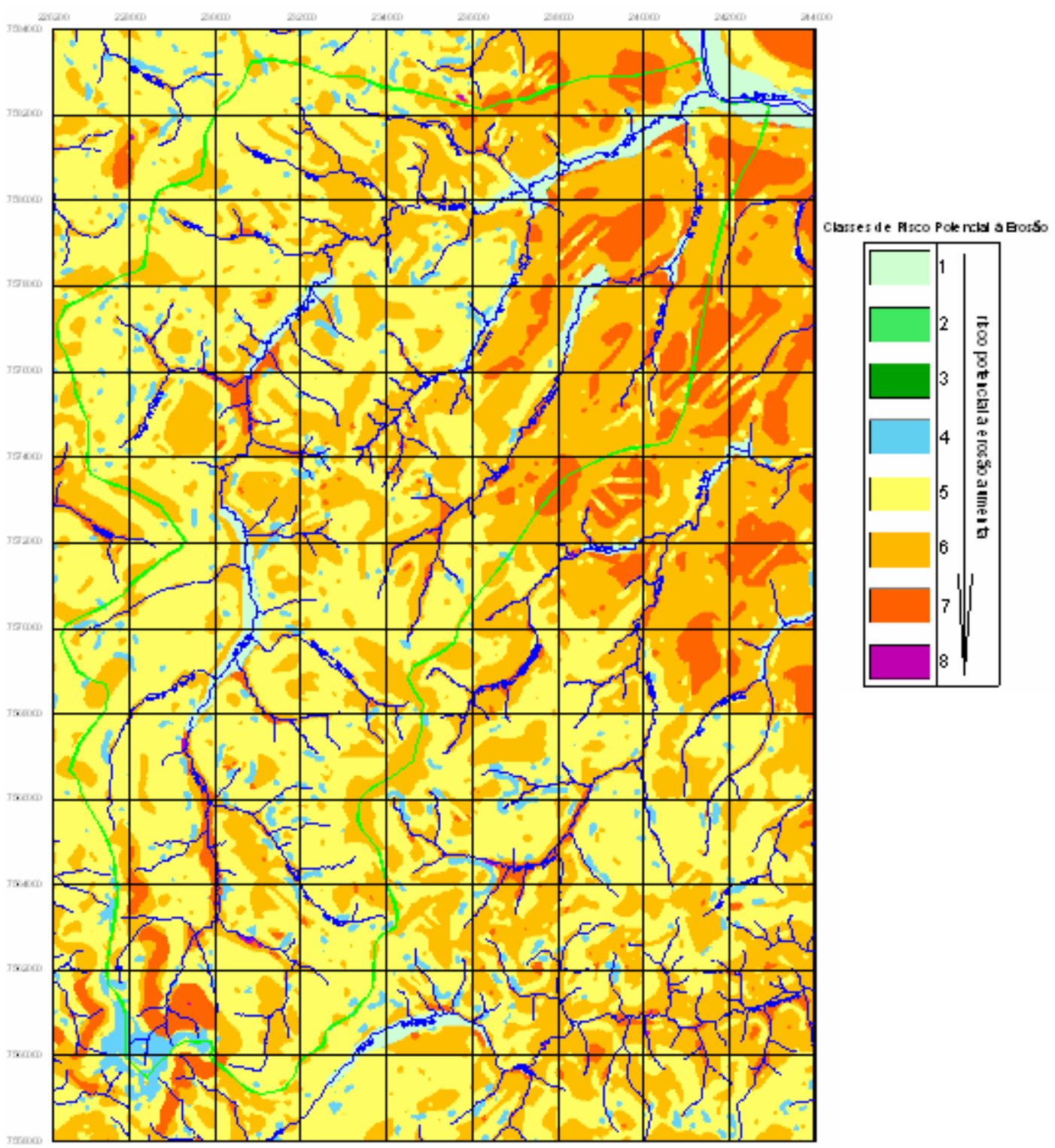

Figura 19. Potencial de risco à erosão da microbacia do rio Bonito. Fonte: Torezan e Lorandi (2000)

\subsection{O MODELO AVSWAT}

\subsubsection{Generalidades}

O modelo ArcView Soil and Water Assessment Tool - AVSWAT é um modelo matemático, em interface com o ArcView, desenvolvido em 1996, pelo Agricultural Research Service e pela Texas A\&M University, objetivando a análise dos impactos das alterações no uso do solo sobre o escoamento superficial e subterrâneo, produção de sedimentos e qualidade da água. Para 
satisfazer a estes objetivos o modelo: (i) é baseado em características físicas da bacia; (ii) usa dados de entrada normalmente disponíveis; (iii) é computacionalmente eficiente para operar sobre médias/grandes bacias e (iv) é contínuo no tempo, sendo capaz de simular longos períodos (>50 anos) de forma a computar os efeitos das alterações no uso do solo.

O modelo AVSWAT é do tipo distribuído, e a bacia hidrográfica pode ser subdividida em sub-bacias de modo a refletir as diferenças de tipo de solo, cobertura vegetal, topografia e uso do solo, sendo possível a subdivisão de centenas à milhares de células, cada célula representando uma sub-bacia.

O modelo foi desenvolvido para predizer o efeito de diferentes cenários de manejo na qualidade da água, produção de sedimentos e cargas de poluentes em bacia hidrográficas agrícolas (SILVA \& CRESTANA, 2003).

O modelo é baseado em uma estrutura de comandos para propagar o escorrimento, sedimentos e agroquímicos através da bacia. Os maiores componentes do modelo incluem hidrologia, clima, sedimentos, temperatura do solo, crescimento de plantas, nutrientes, pesticidas e manejo agrícola. O componente hidrológico do modelo inclui sub-rotinas do escorrimento superficial, percolação, fluxo lateral sub-superficial, fluxo de retorno do aqüífero raso e evapotranspiração. O modelo requer dados diários de, por exemplo, precipitação, temperaturas máximas e mínimas do ar, radiação solar e umidade relativa.

O sistema hidrológico simulado pelo AVSWAT é composto de quatro volumes de controle: (i) reservatório superficial; (ii) reservatório subsuperficial; (iii) reservatório subterrâneo - aqüífero raso; e (iv) reservatório subterrâneo aqüífero profundo. A contribuição destes reservatórios para o escoamento superficial provém do escoamento lateral a partir do perfil de solo e do escoamento de retorno do aqüífero raso. O volume que percola do reservatório subsuperficial, através do perfil de solo, representa a recarga do aqüífero raso.

A água que percola para o aqüífero profundo não retorna para o sistema. A determinação do balanço hídrico é fundamental para a estimativa da 
infiltração, do escoamento superficial e da força de desprendimento pelo fluxo da água. Esse componente utiliza-se das informações dos componentes clima, crescimento vegetal e infiltração para a estimativa da evapotranspiração potencial e evaporação do solo e transpiração das plantas. A partir dessas informações o componente balanço hídrico determina a quantidade e o estado da água no solo diariamente para cada camada e calcula a percolação no perfil do solo, conforme processos demonstrados pela Figura 20 e detalhadamente pela Figura 21.

No modelo AVSWAT a determinação da produção de água da bacia hidrográfica tem como base a equação do balanço hídrico:

$$
S W_{\mathrm{t}}=S W+\sum_{\mathrm{t}=1}^{\mathrm{t}}\left(R_{\mathrm{i}}-Q_{\mathrm{i}}-E T_{\mathrm{i}}-P_{\mathrm{i}}-Q R_{\mathrm{i}}\right)
$$

onde:

SWt = conteúdo final de água no solo $(\mathrm{mm})$;

$S W=$ conteúdo de água no solo disponível para as plantas, definido como o conteúdo de água inicial menos o conteúdo de água no ponto de murcha permanente $(\mathrm{mm})$;

$\boldsymbol{t}=$ tempo (dias);

$\boldsymbol{R} \boldsymbol{i}=$ precipitação $(\mathrm{mm})$;

Qi = escoamento superficial (mm);

$\boldsymbol{E} T \boldsymbol{i}=$ evapotranspiração $(\mathrm{mm})$;

$\boldsymbol{P} \boldsymbol{i}=$ percolação $(\mathrm{mm})$;

$\mathbf{Q R} \boldsymbol{i}=$ fluxo de retorno (ascensão capilar) $(\mathrm{mm})$. 


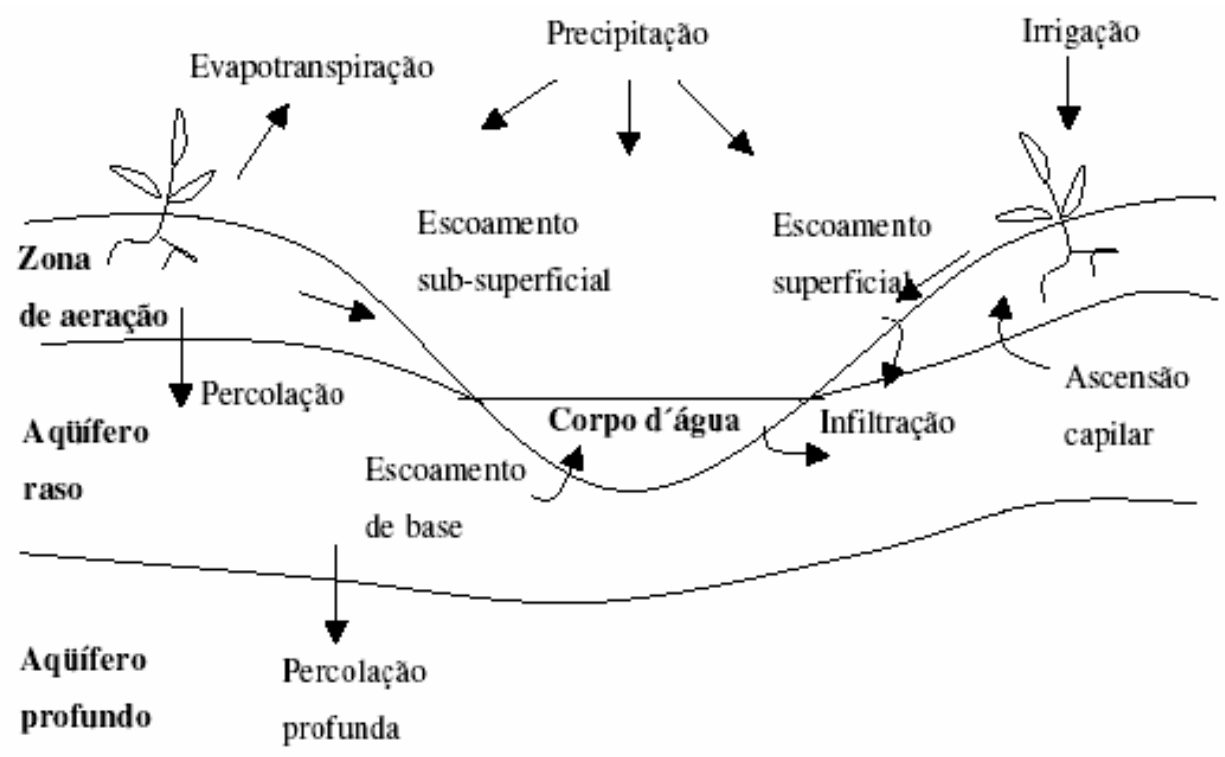

Figura 20. Principais componentes do balanço hídrico simulados pelo AVSWAT Fonte: Arnold et al. (1998).

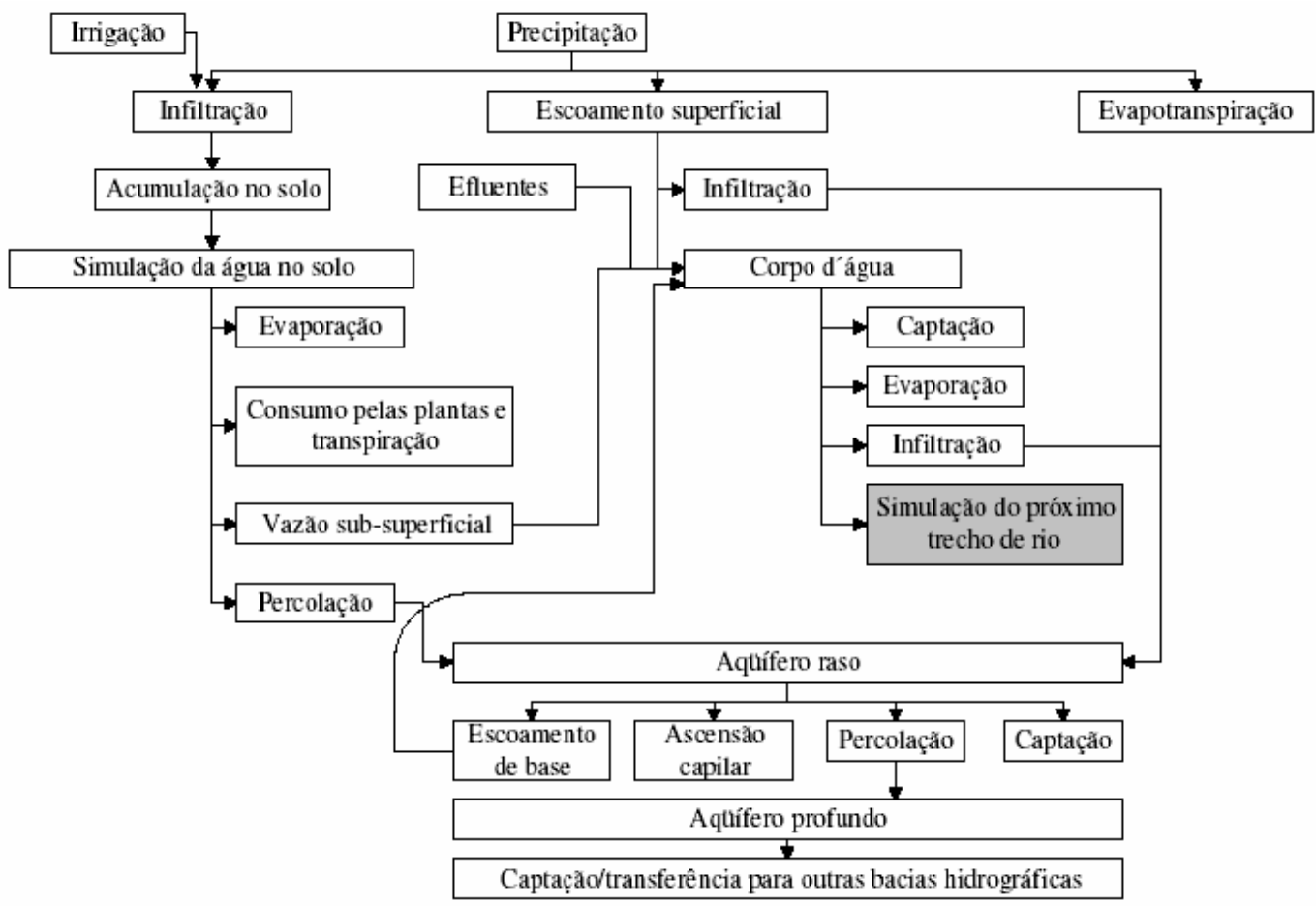

Figura 21. Esquema de caminhos viáveis para o movimento da água, simulados pelo SWAT Fonte: Arnold et al. (1998) e Neitsch et al. (2002a).

O AVSWAT utiliza uma formulação modificada do método da Curva Número (CN) para calcular o escorrimento superficial ao tipo de solo, uso da terra e práticas de manejo. Uma interface (DI LUZIO et al., 2001) foi desenvolvida entre o SWAT e o ARC VIEW. 
Para o propósito da modelagem, o AVSWAT considera a bacia dividida em sub-bacias com base no relevo, solos e uso do solo e, desse modo, preserva os parâmetros espacialmente distribuídos da bacia inteira, bem como suas características homogêneas.

O processo comum, para a divisão da bacia em sub-bacias, consiste em especificar a área limite, a qual é a área mínima necessária de drenagem para um ponto, formando um canal (TRIBE, 1992). Cada sub-bacia pode ser parametrizada pelo AVSWAT usando uma série de Unidades de Resposta Hidrológica (Hidrologic Response Units - HRU's)

As HRU's são partes da sub-bacia que possuem uma única combinação de uso da terra/solo/manejo. Uma ou mais combinações de uso da terra/solo podem ser criadas para cada sub-bacia. Subdividir a bacia em áreas contendo combinações únicas, possibilita ao modelo refletir diferenças na evapotranspiração e outras condições hidrológicas para diferentes usos e solos (MACHADO, 2002).

O escoamento é calculado para cada HRU e propagado para obter o escoamento total para a sub-bacia. Isso pode aumentar precisão das predições e fornecer uma melhor descrição física do balanço de água na bacia (ARNOLD et al., 1998).

Para gerar as HRU's em cada sub-bacia, um nível de sensibilidade é adotado eliminando as classes de uso da terra com área menor do que o valor arbitrado. O segundo passo controla a criação das HRU's com base na distribuição dos diferentes tipos de solo sobre os usos da terra selecionados. $O$ solo com área menor do que o nível de sensibilidade adotado (para solo), também é eliminado. Os processos representativos do modelo são apresentados na Figura 22.

A erosão e a produção de sedimentos são simuladas para cada HRU por intermédio da Equação Universal de Perda de Solo Modificada (MUSLE), a qual é uma versão modificada da USLE desenvolvida por Wischmeier \& Smith (1978). Enquanto na Equação Universal de Perda de Solo (USLE) são 
utilizados os índices de precipitação como índices indicativos da energia da erosão, a MUSLE usa a quantidade de escorrimento superficial para simular a erosão e a produção de sedimentos.

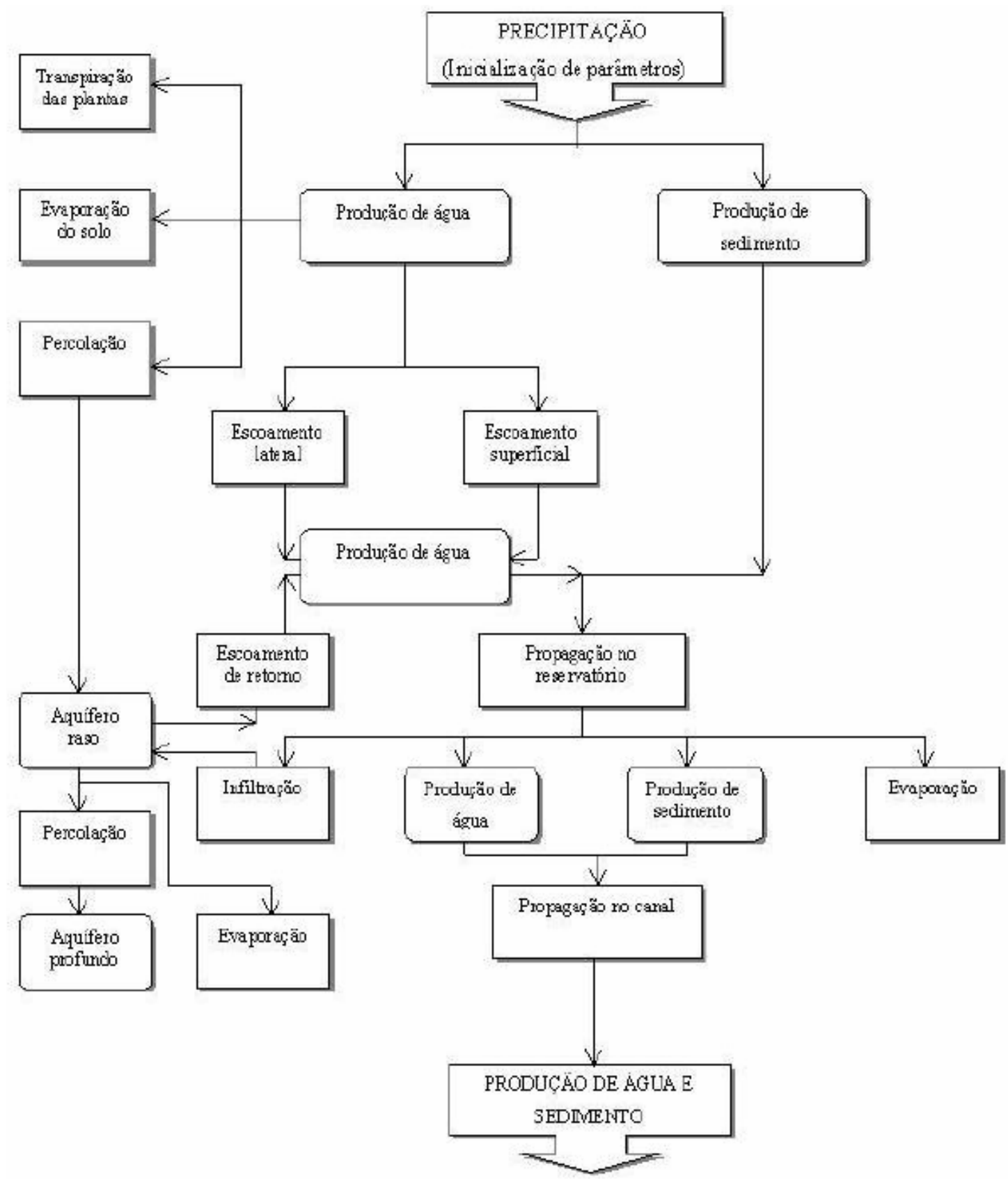

Figura 22. Fluxograma de processamento do AVSWAT

Fonte: King et al. (1996).

A substituição resulta em um número de benefícios (NEITSCH, 2000): a precisão do modelo é aumentada; a necessidade de razão de transporte 
(delivery ratio) é eliminada e permite a equação ser aplicada para eventos de chuva individuais.

$$
\text { sed }=11,8 *\left(Q_{\text {surf }} * q_{\text {peak }} * \text { área } a_{\text {hru }}\right)^{0,56} * K_{\text {USLE }} * C_{\text {USLE }} * P_{\text {USLE }} * \text { LS USLE }
$$

Onde:

sed é a produção de sedimentos em um dado dia (ton);

$\boldsymbol{Q}$ surf é o volume de escoamento superficial $(\mathrm{mm})$;

q peak é a vazão de pico do escoamento (m3/s);

área hru é a área da HRU (ha);

K USLE é o fator erodibilidade do solo;

C USLE é fator de manejo e cobertura do solo;

$\boldsymbol{P}$ USLE é o fator práticas conservacionistas;

LS USLE é o fator topográfico.

O modelo simula também a contribuição de sedimentos a partir das vazões subsuperficiais e de base em função das vazões, área de contribuição e concentração de sedimentos.

No Brasil, os trabalhos de aplicação do modelo AVSWAT restringem-se a poucos pesquisadores, tendo como objeto apenas a geração de sedimentos em processos erosivos, em bacia hidrográficas.

Dentre os pesquisadores, com trabalhos disponíveis na literatura, encontram-se Castro de Oliveira (1999), pesquisa que abordou o impacto das mudanças no uso do solo nas características hidrossedimentológicas da bacia hidrográfica do Rio Joanes, em Salvador, Estado da Bahia; Machado (2002), cujo trabalho foi de simulação do escoamento e produção de sedimentos na bacia hidrográfica do Ribeirão do Marins, afluente do Rio Piracicaba, localizado 
no município de Piracicaba, (SP) e Garrido (2003), que desenvolveu análise na bacia do Rio Jiquiriça, no Estado da Bahia.

Todos os trabalhos, todavia, com ênfase nos processos erosivos e geração de sedimentos nas bacias hidrográficas estudadas.

De forma inédita, a presente pesquisa foi conduzida aprofundando-se os conhecimentos na aplicação e utilização da modelagem hidrossedimentológica, com utilização do modelo AVSWAT, tendo-se como foco o módulo de fertilizantes, especificamente analisado para a realidade da microbacia do Rio Bonito: uma microbacia rural com atividades de confinamento de animais .

\subsubsection{DADOS DE ENTRADA NO MODELO}

Por ser um modelo físico, o AVSWAT requer uma grande quantidade de parâmetros que se relacionam com as características físicas da bacia (Tabela 15). Na definição destes parâmetros buscou-se sempre que possível, utilizar dados obtidos a partir de trabalhos anteriores, evitando-se o levantamento experimental das informações necessárias, o que demandaria uma grande quantidade de tempo.

A entrada de dados no AVSWAT (planos de informação cartográficos PI's e dados alfanuméricos) foi realizada via interface com o ARCVIEW 3.1. Os PI's necessários são: o Modelo Numérico do Terreno (MNT); solos; e uso da terra (MACHADO, 2003).

O AVSWAT possui, também, arquivos de base de dados para auxiliar na entrada de informações, como (NEITSCH et al., 2002b):

- dados de crescimento das plantas para tipos de cobertura do solo existentes numa bacia;

- dados de manejo agrícola definindo quantidade e profundidade de mistura por tipo de manejo realizado no solo da bacia;

- dados de mobilidade e degradabilidade para pesticidas presentes numa bacia; 
- informações sobre a constituição nutricional de fertilizantes aplicados numa bacia;

- $\quad$ informações sobre a relação área construída/produção e transporte de sedimentos em áreas urbanas. 
Tabela 15. Dados gerais de entrada para utilização do modelo SWAT

\begin{tabular}{|c|c|c|}
\hline Dados de entrada & Detalhe dos dados de entrada & Observações \\
\hline Modelo Digital de Elevaçôes (MDE). & Altimetria georreferenciada. & - \\
\hline $\begin{array}{l}\text { Rede hidrográfica para melhor } \\
\text { identificaçẫo da localizaçấo dos rios pelo } \\
\text { MDE. (Opcional) }\end{array}$ & Mapa da rede hidrográfica. & - \\
\hline $\begin{array}{l}\text { Máscara com definição dos limites da } \\
\text { bacia. (Opcional) }\end{array}$ & Mapa digital com definição dos limites da bacia. & ( \\
\hline Pontos de saída de interesse. & Coordenadas das saídas & ex.: localizaçăo de estaçð̃es fluviométricas. \\
\hline Fontes pontuais de poluição.(Opcional) & $\begin{array}{l}\text { Coordenadas das fontes Dados necessários: } \\
\text { periodicidade, vazão, carga de sedimento, } \mathrm{N} \text { orgânico, } \\
\mathrm{P} \text { orgânico, nitrato, P solúvel, amônia, nitrito, metais e } \\
\text { bactérias. }\end{array}$ & - \\
\hline Usos consuntivos & $\begin{array}{l}\text { Coordenadas da captação. Dados de vazão captada } \\
\text { com periodicidade diária, mensal, anual ou média } \\
\text { anual. }\end{array}$ & - \\
\hline Reservatórios/Lagos & Coordenadas e características físicas. & - \\
\hline Uso/Cobertura do solo na bacia. & $\begin{array}{l}\text { Mapa e Tabela com características dos usos do solo } \\
\text { (agro-pecuário e urbano) identificados no mapa. }\end{array}$ & $\begin{array}{l}\text { O SWAT dispõe de base de dados para } \\
\text { auxílio à definição das características do } \\
\text { uso/cobertura do solo. }\end{array}$ \\
\hline Tipos de solo da bacia hidrográfica. & $\begin{array}{l}\text { Mapa e Tabela com características físicas e químicas } \\
\text { dos tipos de solos indicados }\end{array}$ & $\begin{array}{l}\text { O SWAT dispôe de base de dados do USGS } \\
\text { para auxílio à definiçâao das características } \\
\text { dos tipos de solo. }\end{array}$ \\
\hline Estaçðes climatológicas. & $\begin{array}{l}\text { Código, nome e coordenadas das estações. Dados } \\
\text { médios mensais e desvio padrão de temperatura } \\
\text { máxima e mínima do ar, precipitaçăo, radiaça solar, } \\
\text { temperatura de orvalho e velocidade do vento. }\end{array}$ & $\begin{array}{l}\text { O nome será utilizado para identificação da } \\
\text { estaçăo na base de dados do modelo. }\end{array}$ \\
\hline
\end{tabular}


(continuação)

\begin{tabular}{|c|c|c|}
\hline Dados de entrada & Detalhe dos dados de entrada & Observaçoes \\
\hline Canal & Características físicas do canal & - \\
\hline $\begin{array}{l}\text { Águas subterrâneas (aquífero raso e } \\
\text { profundo) }\end{array}$ & Características físicas dos aquíferos & - \\
\hline HRU/Sub-bacia & Carac terísticas físicas da HRU e/ou sub-bacia. & - \\
\hline Estaçoes pluviométricas. (Opcional) & $\begin{array}{l}\text { Código, nome, coordenadas e altitude das estações. } \\
\text { Dados diários de precipitação. }\end{array}$ & $\begin{array}{l}\text { O nome será utilizado para identificação da } \\
\text { estação na base de dados do modelo. }\end{array}$ \\
\hline Evapotranspiração potencial. (Opcional) & Dados diários de evapotranspiração potencial & 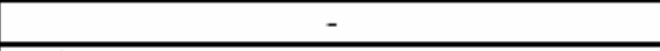 \\
\hline Pesticida. (Opcional) & Identificaçåo do tipo e composição de pesticidas. & $\begin{array}{l}\text { O SWAT dispó de base de dados de tipos } \\
\text { de pesticidas para auxílio à definiçấo das } \\
\text { suas características. }\end{array}$ \\
\hline Fertilizantes. (Opcional) & Identificação do tipo e composição de fertilizantes. & $\begin{array}{l}\text { O SWAT dispóe de base de dados de tipos } \\
\text { de fertilizantes para auxílio à definição das } \\
\text { suas características. }\end{array}$ \\
\hline agro-pecuário/urbano. & Identificaçăo do tipo de manejo e suas características. & $\begin{array}{l}\text { O SWAT dispõe de base de dados de tipos } \\
\text { de manejo para auxílio à definiçâo das suas } \\
\text { características. }\end{array}$ \\
\hline
\end{tabular}

Fontes: Di Luzio et al (2002) e Neitch et al (2002). Adaptado de Garrido (2003). 


\subsection{Mapa de hidrografia, uso e cobertura do solo e tipos de solos.}

Os mapas digitais da hidrografia (Figura 23), uso e cobertura do solo (Figura 24) e tipos de solos (Figura 25) foram obtidos a partir do trabalho de Moraes e Lorandi (2003), os quais foram cedidos pelos autores para o propósito específico da modelagem, na presente pesquisa.

Conforme já exposto, há predominância do cultivo de cana-de-açúcar e pastagens na microbacia. Em relação aos solos, predominam o grupo dos Latossolos.

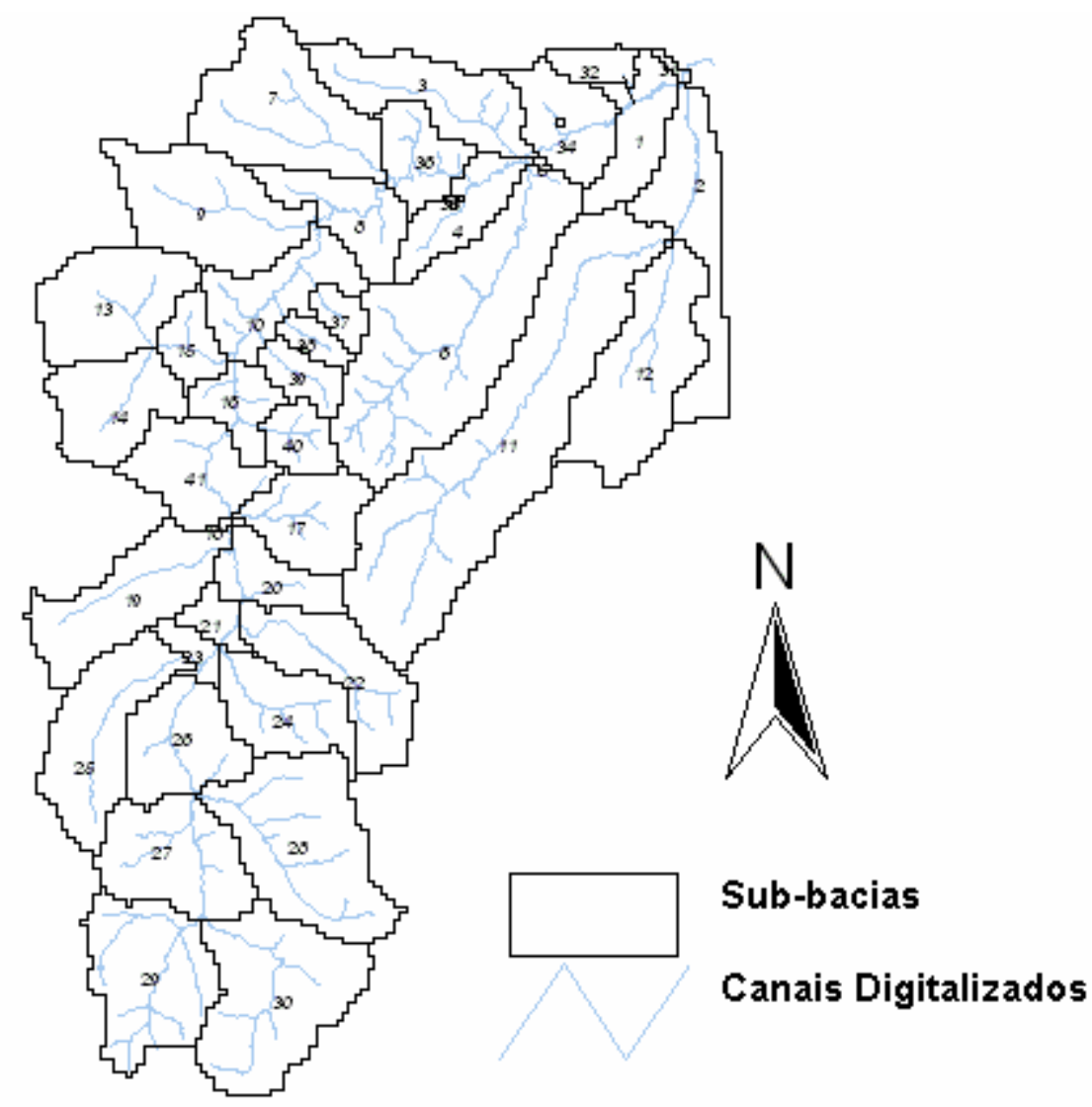




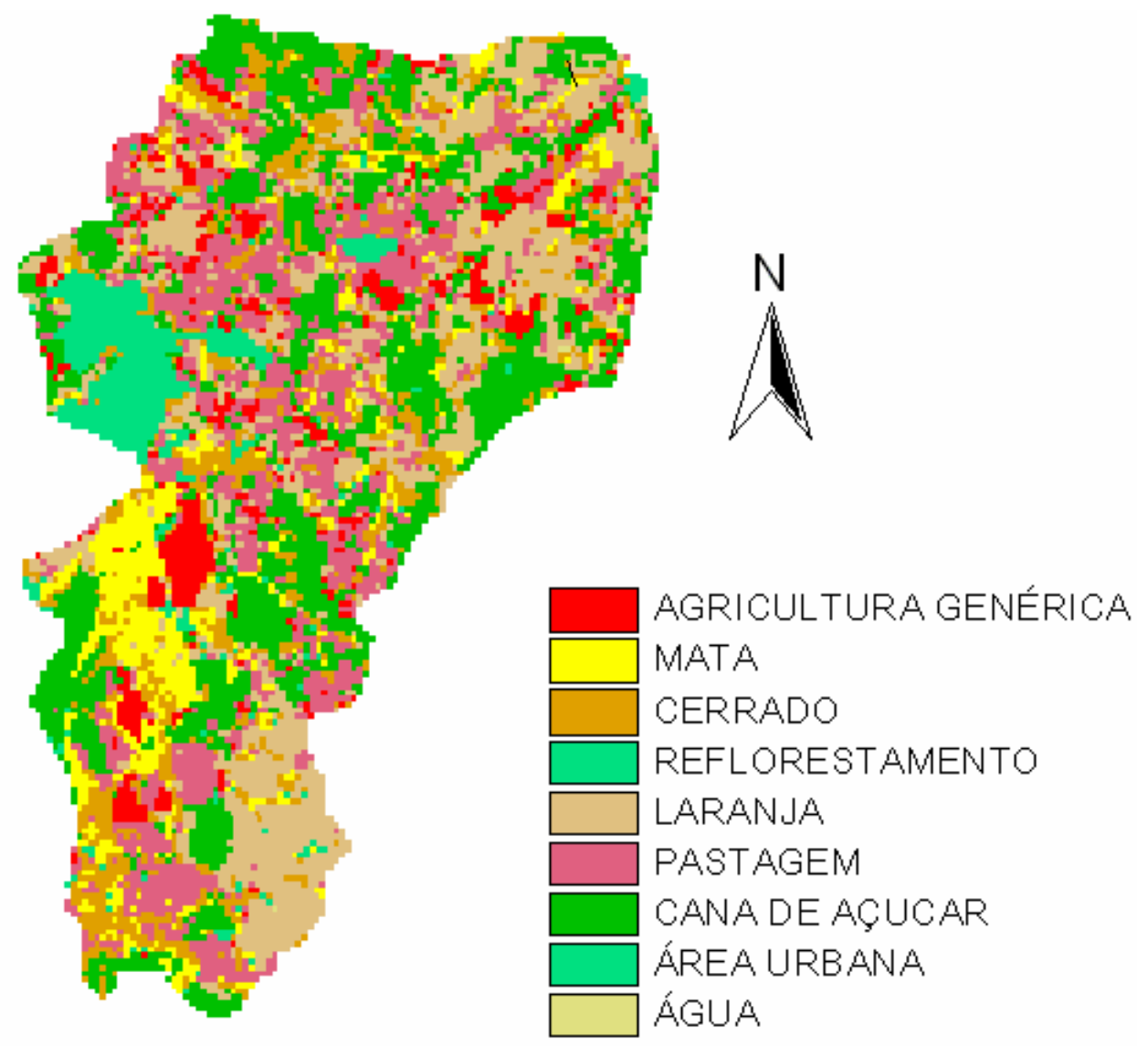

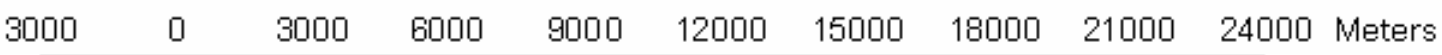

Figura 24. Uso e ocupação do solo da Microbacia Hidrográfica do Rio Bonito - Descalvado $(S P)$.

Fonte: Modificado de Moraes e Lorandi, 2003. 


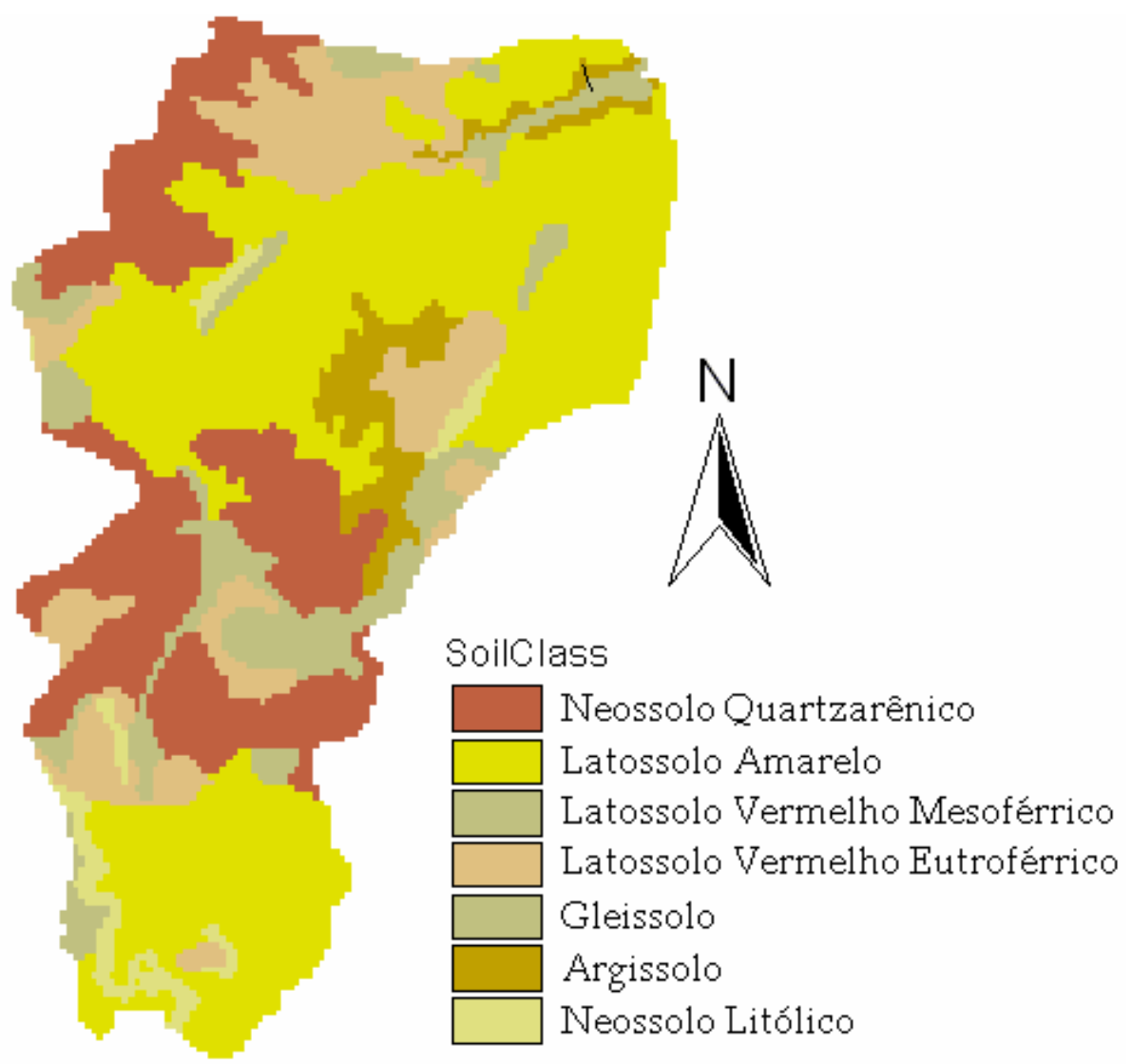

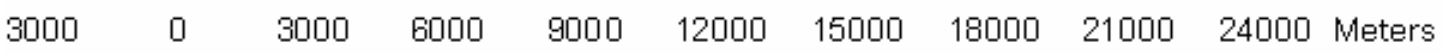

Figura 25. Tipos de solos da Microbacia Hidrográfica do Rio Bonito - Descalvado (SP).

Fonte: Modificado de Moraes e Lorandi, 2003 


\subsection{Parâmetros Climatológicos}

Em relação à climatologia, o modelo requer dados diários de precipitação, temperaturas máxima e mínima do ar, radiação solar, velocidade do vento e umidade relativa. Os valores para esses parâmetros podem ser lidos a partir de registros de dados observados ou podem ser gerados pelo modelo.

No AVSWAT está incluindo o modelo gerador climático WXGEN (SHARPLEY e WILLIAMS, 1990). O arquivo de entrada do gerador climático deve conter dados mensais necessários para gerar dados climáticos diários representativos para simular o clima da região. Esses dados climáticos diários são gerados pelo modelo em duas situações: quando é especificado que os dados irão ser gerados, ou quando algum dado está faltando.

Com base nos dados diários da estação meteorológica da FAZENDA CANCHIM, localizada em São Carlos, Estado de São Paulo, as informações de clima correspondentes ao período de 1992 a 2004, foram obtidas e digitadas em tabelas, utilizando-se o ARC-VIEW. Os dados diários de umidade relativa foram gerados pelo SWAT, utilizando-se o gerador climático WXGEN.

Para determinação da evapotranspiração potencial, o modelo oferece três métodos: Hargreaves, Priestley-Taylor e Penman-Monteith. O método Penman- Monteith, embora requeira um maior número de informações, apresentou resultados mais coerentes com a realidade da microbacia hidrográfica em estudo (NEVES, et al, 2005b).

Os dados de clima, para informação no modelo, estão tabulados na Tabela 16, em médias mensais para o período de 13 anos considerados para simulação. 
Tabela 16. Médias climatológicas mensais da MBHRB no período de 1992 a 2004.

\begin{tabular}{|c|c|c|c|c|c|}
\hline & $\begin{array}{c}\text { Temperatura } \\
\text { máxima do ar } \\
\left({ }^{\circ} \mathrm{C}\right)\end{array}$ & $\begin{array}{c}\text { Temperatura } \\
\text { mínima do ar } \\
\left({ }^{\circ} \mathrm{C}\right)\end{array}$ & $\begin{array}{l}\text { Precipitação } \\
\left(\mathrm{mm} \mathrm{H}_{2} \mathrm{O}\right)\end{array}$ & $\begin{array}{c}\text { Radiação } \\
\text { solar } \\
\text { (MJ/m²/dia) }\end{array}$ & $\begin{array}{l}\text { Velocidade } \\
\text { do vento } \\
(\mathrm{m} / \mathrm{s})\end{array}$ \\
\hline Jan & 28,37 & 18,71 & 262,32 & 19,14 & 3,10 \\
\hline Fev & 28,47 & 18,67 & 240,78 & 17,09 & 3,5 \\
\hline Mar & 28,20 & 18,05 & 123,75 & 18,19 & 3,5 \\
\hline Abr & 27,36 & 16,42 & 59,14 & 16,99 & 4,0 \\
\hline Mai & 24,55 & 13,65 & 56,97 & 14,30 & 3,10 \\
\hline Jun & 24,10 & 12,33 & 37,04 & 13,96 & 3,10 \\
\hline Jul & 24,67 & 12,38 & 21,11 & 15,81 & 3,10 \\
\hline Ago & 26,70 & 13,03 & 18,19 & 17,63 & 3,10 \\
\hline Set & 27,43 & 15,02 & 61,19 & 17,69 & 4,00 \\
\hline Out & 28,39 & 16,39 & 110,13 & 19,70 & 4,00 \\
\hline Nov & 28,08 & 17,19 & 155,13 & 20,60 & 4,00 \\
\hline Dez & 28,13 & 18,06 & 218,05 & 20,21 & 4,00 \\
\hline
\end{tabular}

Fonte: Estação climatológica Fazenda Canchim. São Carlos (SP)

\subsection{Parâmetros de solo}

A partir das características dos solos da microbacia de estudo, chegouse, inicialmente, a uma classificação utilizada no método do Soil Conservation Service-SCS, a qual apresenta grupos de solos hidrológicos designados por A, $B$, $C$ e $D$, de forma que o solo do tipo $A$ tem o mais baixo potencial de escoamento, e o solo do tipo D, o mais alto potencial de escoamento.

No entanto, como os solos norte americanos são diferenciados dos solos brasileiros, optou-se por acolher a definição e agrupamento hidrológico definidos por Lombardi Neto et al (1989), os quais basearam-se no trabalho de levantamento e reconhecimento dos solos do Estado de São Paulo, estabelecendo quatro grupos de solos, de acordo com suas qualidades e características, visando sua aplicação em práticas conservacionistas, principalmente terraços. Os solos do Estado de São Paulo foram enquadrados nestes grupos levando em consideração a profundidade, permeabilidade, textura da camada superficial e subsuperficial, e a relação textural da argila entre os horizontes A e B.

As características dos quatro grupos hidrológicos de solos definidos por Lombardi Neto et al. (1989) são descritos a seguir e resumidos na Tabela 17. 
- Grupo A: Incluem solos com alta taxa de infiltração, mesmo quando completamente molhados e com alto grau de resistência e de tolerância a erosão. Eles normalmente são profundos ou muito profundos, porosos com baixo gradiente textural, menor que 1,20, de textura média, argilosa ou mesmo muito argilosa desde que a estrutura proporcione alta macroporosidade em todo o perfil, resultando em solos bem drenados ou excessivamente drenados.

- Grupo B: Compreendem os solos com moderada taxa de infiltração, mesmo quando completamente molhados ou com alta taxa de infiltração, mas com moderada resistência e tolerância à erosão. São normalmente profundos, com relação textural entre 1,20 a 1,50. A drenagem do perfil é boa ou moderada.

- Grupo C: Enquadram-se os solos com baixa taxa de infiltração mesmo quando completamente molhados, com baixa resistência e tolerância a erosão. São normalmente profundos ou moderadamente profundos, com relação textural maior que 1,5 , comumente apresentando relação textural abrupta.

Grupo D: Possuem solos com taxa de infiltração muito baixa, mesmo quando completamente molhados, e muito baixa resistência e tolerância à erosão. São normalmente rasos e/ou permeáveis ou então com mudança textural abrupta aliada à argila de alta atividade ( $\mathrm{Ta}$ ) ou ainda com camada de impedimento à infiltração de água (piçarra, fragipã, etc.). 
Tabela 17. Grupamento de solos segundo suas qualidades, características e resistência à erosão.

\begin{tabular}{|c|c|c|c|c|c|c|}
\hline \multirow[t]{2}{*}{ Grupo } & \multirow{2}{*}{$\begin{array}{c}\text { Grupo de } \\
\text { Resistência à } \\
\text { erosào }\end{array}$} & \multicolumn{5}{|c|}{ Principais Caracteristicas } \\
\hline & & Profundidade & Permeabilidade & Textura & $\begin{array}{c}\text { Razào } \\
\text { Textural }^{(1)}\end{array}$ & $\begin{array}{c}\text { Grandes Grupos de } \\
\text { Solos }^{(4)}\end{array}$ \\
\hline A & alto & $\begin{array}{l}\text { muito profundo }(>2 \mathrm{~m}) \mathrm{\alpha l} \\
\text { profundo }(1 \mathrm{a} 2 \mathrm{~m})\end{array}$ & $\begin{array}{l}\text { rápida/rảpida } \\
\text { moderada/rápida }\end{array}$ & $\begin{array}{l}\text { média/média } \\
\text { muito argilosa/muito } \\
\text { argilosa } \\
\text { argilosa/argilosa }\end{array}$ & $<1,2$ & $\begin{array}{l}\text { LR, LE, LV, LVr, } \\
\text { LVt, LH, LEa, e LVa }\end{array}$ \\
\hline B & moderado & profundo (1 a 2m) & $\begin{array}{l}\text { rápida/rápida } \\
\text { rápida/moderada } \\
\text { moderada/moderada }\end{array}$ & $\begin{array}{l}\text { arenosa/arenosa } \\
\text { arenosa/média } \\
\text { arenosa/argilosa } \\
\text { média/argilosa } \\
\text { argilosa/muito argilosa }\end{array}$ & 1,2 a 1,5 & $\begin{array}{l}\text { LJ, LVP, PV, PVL, } \\
\text { Pln, TE, PVls. R, } \\
\text { RPV, RLV, LEa }{ }^{(3)}, \text { e } \\
\text { LVa }^{(3)}\end{array}$ \\
\hline $\mathrm{C}$ & baixo & $\begin{array}{l}\text { profundo ( } 1 \text { a } 2 \mathrm{~m}) \\
\text { moderadamente profundo }(0,5 \\
\mathrm{a} 1,0 \mathrm{~m})\end{array}$ & $\begin{array}{l}\text { lenta/rápida } \\
\text { lenta/moderada } \\
\text { rápida/moderada }\end{array}$ & $\begin{array}{l}\text { arenosa/média }{ }^{(2)} \\
\text { média/ argilosa }^{(2)} \\
\text { arenosa/argilosa } \\
\text { arenosa/muito argi losa }\end{array}$ & $>1,5$ & $\begin{array}{l}\text { Pml, PVp, PVls, Pce } \\
\text { M }\end{array}$ \\
\hline D & muito baixo & $\begin{array}{l}\text { Moderadamente profundo }(0,5 \\
\text { a } 1,0 \mathrm{~m}) \text { al raso }(0,25 \text { a } 0,50 \mathrm{~m}\end{array}$ & $\begin{array}{l}\text { rápida, moderada al } \\
\text { lenta sobre lenta }\end{array}$ & muito variável & $\begin{array}{c}\text { muito } \\
\text { variável }\end{array}$ & $\begin{array}{l}\text { Li-b, Li-ag, gr, Li- } \\
\text { fi, Li-ac e PVp } \\
\text { (rasos) }\end{array}$ \\
\hline
\end{tabular}

${ }^{(1)}$ Média da porcentagem de argila do horizonte B (excluindo B3) sobre média da porcentagem de argila de todo horizonte $\mathrm{A}$.

${ }^{(2)}$ Somente com mudança textural abrupta entre os horizontes A e B.

(3) Somente aqueles com horizonte A arenoso.

${ }^{(4)}$ Legenda de Brasil, 1960.

Fonte: Lombardi Neto et al., (1989) apud Sartori (2004).

\subsection{Parâmetros de cobertura do solo}

O fator Curva Número-CN foi determinado para cada HRU (Unidade de Resposta Hidrológica), com base no tipo e cobertura do solo. As informações foram obtidas a partir dos mapas de uso e ocupação do solo.

O método da $\mathrm{CN}$, originalmente desenvolvido pelo SCS para uso em bacias rurais, está relacionado com as principais propriedades que produzem runoff em uma bacia hidrográfica, como o tipo de solo, tipo de vegetação, condições da superfície e umidade antecedente. O método é usado, na prática, para determinar o volume de runoff baseando-se na altura da chuva e na Curva Número sem explicitamente considerar a intensidade e a duração da chuva. 
Foram consideradas, numericamente, as curvas-número conforme a Tabela 18, para as diferentes coberturas e tipos de solo, levando em consideração o grupo hidrológico a que está compreendido.

Tabela 18. Número da curva de escoamento superficial para usos agrícola (la=0,2.S, condição II de umidade antecedente e condição hidrológica superficial média).

\begin{tabular}{|l|l|c|c|c|c|}
\hline \multirow{2}{*}{ DESCRIÇÃo DA COBERTURA } & \multicolumn{4}{c|}{ Número da curva para } \\
os grupos hidrológicos
\end{tabular}

\section{Legenda}

$\mathbf{N}^{*}$ : Plantio em nível ou contorno

Ca: Culturas anuais (plantio e colheita anual). Exemplo: milho, soja, etc.

Ct: Culturas temporárias (plantio a cada três ou mais anos). Exemplo: cana-de-açúcar

Cp: Culturas perenes. Exemplo: pomar, café.

SRC: Sem resíduo cultural

RCI: Resíduo cultural incorporado $<2 \mathrm{t} / \mathrm{ha}$

RCSI: Resíduo cultural semi-incorporado 2 a 4 t/ha

RCS: Resíduo cultural na superfície $>5$ t/ha

\section{Pastagem:}

- Degradada - presença de compactação superficial, utilização de queimadas, e até $25 \%$ da área sem vegetação, mesmo no período chuvoso;

- Nativa - pasto natural sendo feito controle de manejo de animais e limpezas esporádicas;

- Melhorada - correção de acidez e fertilização, plantio de gramíneas adaptadas, manejo de animais.

Fonte: Sartori (2004). 


\subsection{Parâmetros de fertilizantes}

O movimento de nutrientes, pesticidas e outros parâmetros de qualidade da água para os cursos d'água depende, normalmente, de processos de desgaste e erosão do solo. O AVSWAT simula a movimentação do:

- nitrato e pesticidas em solução transportados por escoamento superficial, vazão sub-superficial e percolação;

- nitrogênio orgânico, fósforo orgânico e mineral e pesticidas, aderidos às partículas de solo, transportados pelo escoamento superficial;

- fósforo inorgânico em solução, presente nos primeiros $10 \mathrm{~mm}$ da camada de solo, transportado pelo escoamento superficial;

- valor de carbono orgânico que atinge os rios transportado por escoamento superficial.

O transporte de partículas e elementos no canal é função dos processos de deposição e degradação dos sedimentos no curso d'água.

Para os nutrientes Nitrogênio e Fósforo, o AVSWAT simula o ciclo completo. O modelo considera os nutrientes dissolvidos na água e os adsorvidos nas partículas de sedimento, os primeiros acompanham o fluxo de água e os segundos são depositados junto aos sedimentos no fundo do canal. O AVSWAT apresenta ainda duas opções: a simulação dos nutrientes sem considerar os processos de transformações ocorridas no rio ou com a consideração de tais transformações.

Em relação á fase terrestre, o Nitrogênio é essencial para o crescimento de plantas. Apresenta-se em três formas no solo: nitrogênio orgânico no húmus, formas minerais presas a colóides e em solução. Pode ser adicionado ao solo por fertilização, fixação por bactérias e chuva, podendo ser removido pelas plantas e por lixiviação, volatilização, desnitrificação e erosão.

O AVSWAT monitora cinco formas do nitrogênio no solo: formas inorgânicas (NH4 + e NO3-) e formas orgânicas (recente - associada a resíduos de plantas e biomassa, estável e ativa - associada a substâncias húmicas). 
A Figura 26 demonstra esquematicamente os processos simulados pelo modelo no ciclo do nitrogênio.

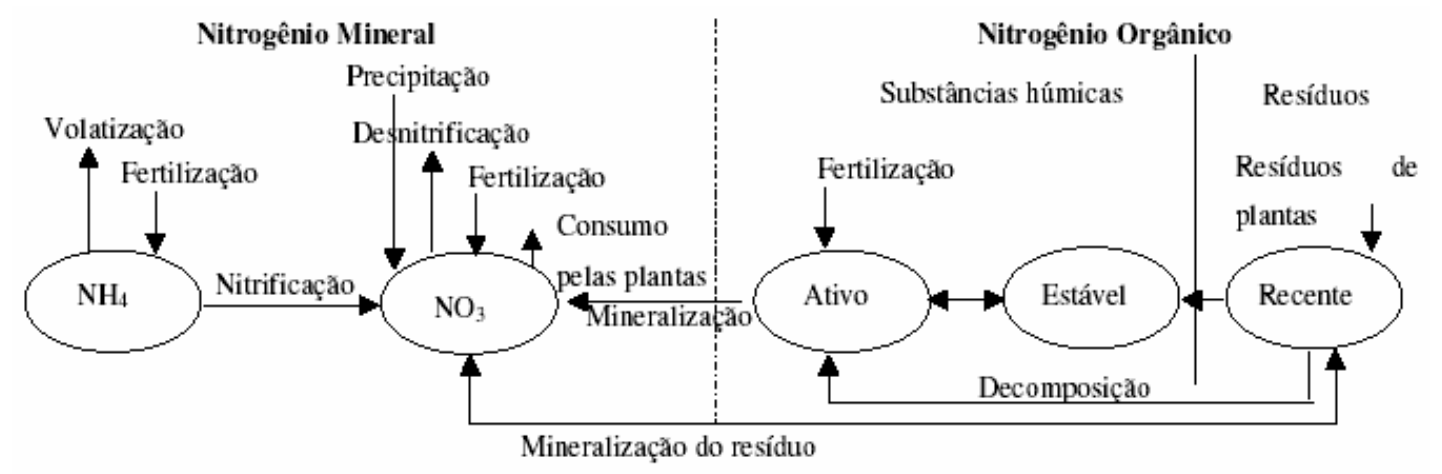

Figura 26. Formas e processos do Nitrogênio simulados pelo SWAT na fase terrestre Fonte: (modificado - NEITSCH et al., 2002a).

O nitrogênio orgânico ligado às partículas do solo, é transportado pelo escoamento superficial para o canal principal. Esta forma de nitrogênio é associada à carga de sedimentos da HRU (Unidade de Resposta Hidrológica) e mudança na carga de sedimentos irão refletir diretamente na carga de nitrogênio orgânico. O total de nitrogênio orgânico transportado com sedimentos para o canal é calculado pela função de carga desenvolvida por McElroy et al (1976) e modificada por Williams e Hann (1978) apud Neitsch et al (2002):

$$
\operatorname{org} N_{\text {surf }}=0.001 \cdot \text { conc }_{\text {orgN }} \cdot \frac{\text { sed }}{\text { area }} \cdot \varepsilon_{\text {hru }}
$$

Onde:

org $N_{\text {surf }}$ é o total de nitrogênio orgânico transportado para o canal principal pelo escorrimento superficial (Kg N/ha);

conc $_{\text {orgn }}$ é a concentração de nitrogênio orgânico nos $10 \mathrm{~mm}$ superficiais da camada de solo (g N/ton de solo);

sed é a carga e sedimentos num determinado dia (ton);

area $_{h r u}$ é a área da HRU (ha); 
$\Sigma_{N}$ é a razão de enriquecimento de nitrogênio

A concentração de nitrogênio orgânico na camada superficial do solo,

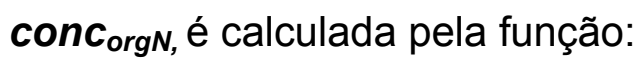

$$
\text { conc }_{\text {org } N}=100 \cdot \frac{\left(\operatorname{org} N_{\text {frsh }, \text { surf }}+\text { org } N_{\text {sta,surf }}+\text { org } N_{\text {act,surf }}\right)}{\rho_{b} \cdot \text { depth }}
$$

Onde:

$\operatorname{org} N_{\text {frsh,surf }}$ é o nitrogênio ( $\mathrm{kg} \mathrm{N} / \mathrm{ha}$ ) na forma orgânica (fresca) nos $10 \mathrm{~mm}$ superficiais do solo;

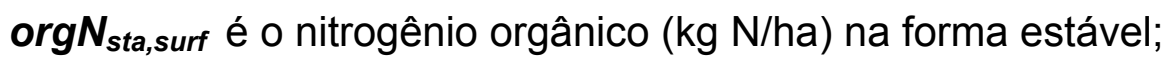

orgN $N_{\text {act,surf }}$ é o nitrogênio ( $\mathrm{Kg} \mathrm{N} / \mathrm{ha}$ ) na forma orgânica ativa, nos $10 \mathrm{~mm}$ superficiais do solo;

$\boldsymbol{\rho}_{b}$ é a densidade $(\mathrm{Mg} / \mathrm{m} 3)$ da primeira camada do solo;

depth $_{\text {surf }}$ é a profundidade da camada superficial do solo (10 mm).

O AVSWAT simula os processos de mineralização, decomposição, imobilização, nitrificação, volatilização da amônia, desnitrificação, nitrogênio devido à chuva, fixação, movimento ascendente do nitrato na água e lixiviação.

Na fase aquática, o AVSWAT simula a transformação de nitrogênio orgânico para amônia, deste para nitrito e finalmente nitrato. Além disso, o nitrogênio orgânico também pode ser removido da água por deposição.

A quantidade de nitrogênio orgânico é simulada considerando-se que sua quantidade pode aumentar pela conversão de biomassa nitrogenada das algas e pode diminuir por dois processos: conversão em NH4 + e deposição.

O modelo considera que a quantidade de amônia pode ser aumentada pela mineralização do nitrogênio orgânico e pela difusão da amônia dos 
sedimentos depositados no fundo do canal, podendo ser diminuída pela conversão em nitrito e pelo consumo pelas algas.

A simulação da quantidade de nitrito no rio leva em consideração o aumento provocado pela conversão de amônia e a diminuição resultante da conversão em nitrato. As transformações de nitrito em nitrato são mais rápidas que as de amônia para nitrito, o que indica o aspecto de serem baixos os níveis de nitrito nos rios.

A quantidade de nitrato no rio é incrementada pela oxidação do nitrito e diminuída pelo consumo do nitrato pelas algas.

Já em relação a outro nutriente de interesse para o estudo, o Fósforo, apresenta-se muito importante para a transferência e o armazenamento de energia pelas plantas, havendo três formas em solos minerais: Fósforo orgânico no húmus, formas insolúveis de Fósforo mineral e Fósforo em solução disponível para as plantas. O Fósforo pode ser adicionado ao solo por fertilização e removido pelas plantas e erosão. Combinado com outros íons, forma diversos compostos insolúveis que precipitam e são facilmente transportados pelo escoamento superficial.

O AVSWAT monitora seis formas do Fósforo no solo: três formas inorgânicas (estável, ativo e em solução) e três formas orgânicas (recente associada a resíduos de plantas, estável e ativo - associada a substâncias húmicas). A Figura 27 demonstra esquematicamente os processos simulados pelo modelo no ciclo do Fósforo.

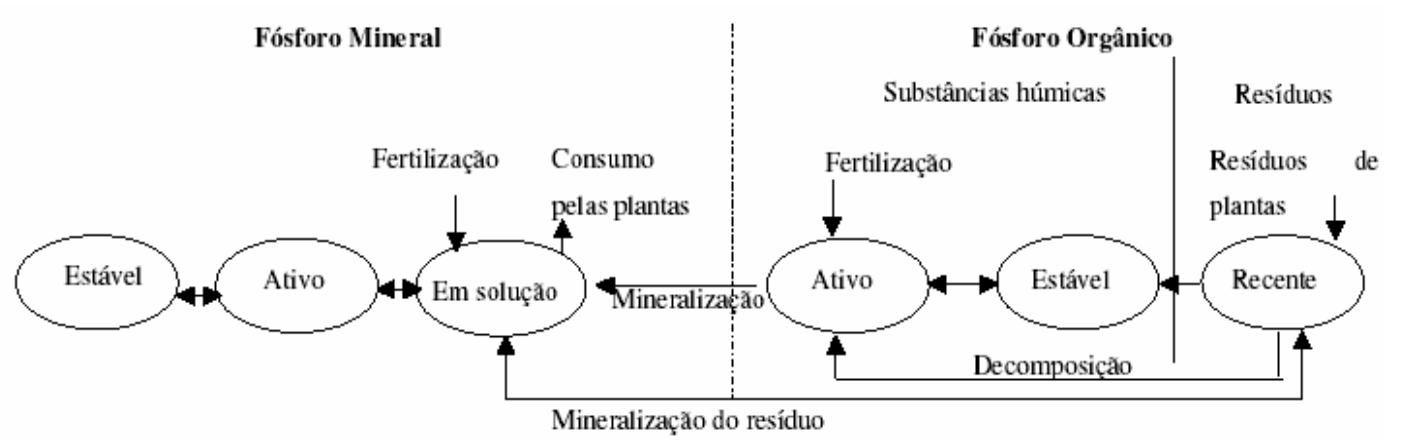

Figura 27. Formas e processos do Fósforo simulados pelo AVSWAT na fase terrestre Fonte: (modificado - NEITSCH et al., 2002a). 
O AVSWAT simula os processos de mineralização, decomposição, imobilização, sorção de fósforo inorgânico e lixiviação.

Da mesma maneira que o nitrogênio, o fósforo orgânico e mineral ligado às partículas do solo é transportado pelo escoamento superficial para o canal principal, mantendo a mesma relação com o carga de sedimento gerada pela $\mathrm{HRU}$, descrita para o nitrogênio, ou seja, as mudanças na carga de sedimentos irão refletir diretamente na carga de fósforo. O total de fósforo transportado com sedimentos para o canal é calculado pela função de carga desenvolvida por McELROY et al (1976) e modificada por Williams e Hann (1978) apud Neitsch et al (2002):

$$
\operatorname{sedP}_{\text {surf }}=0.001 \cdot \operatorname{conc}_{\text {sedP }} \cdot \frac{\text { sed }}{\text { area }} \cdot \varepsilon_{\text {hru }} \text { :sed }
$$

Onde:

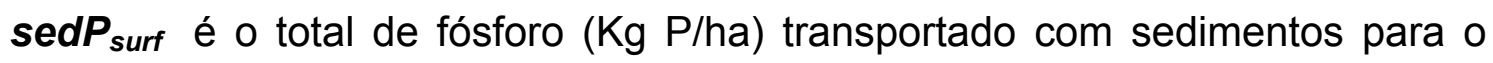
canal principal pelo escoamento superficial;

conc $_{\text {sed }} \boldsymbol{P}$ é a concentração de fósforo (g P/ton de solo) ligada ao sedimento na camada superficial do solo, $10 \mathrm{~mm}$;

sed é a carga e sedimentos (ton) num determinado dia;

area $_{h r u}$ é a área da HRU (ha);

$\Sigma_{P}$ é a razão de enriquecimento de fósforo.

A concentração do fósforo ligado ao sedimento na camada superficial do solo, conc sedP , é calculada:

$$
\operatorname{conc}_{\text {sed } P}=100 \cdot \frac{\left(\min P_{\text {act, suff }}+\min P_{\text {sta,surf }}+\operatorname{org} P_{\text {hun }, \text { surf }}+\operatorname{org} P_{f r s i, \text { surf }}\right)}{\rho_{b} \cdot \operatorname{depth} h_{\text {suff }}}
$$


Onde:

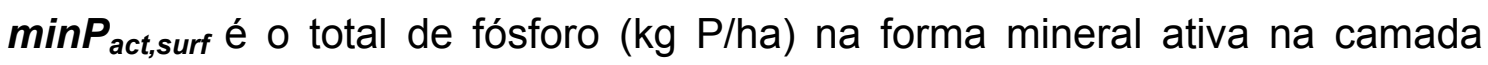
superficial do solo, $10 \mathrm{~mm}$;

$\boldsymbol{m i n} \boldsymbol{P}_{\text {sta,surf }}$ é o total de fósforo $(\mathrm{Kg} \mathrm{P} / \mathrm{ha})$ na forma mineral estável na camada superficial do solo, $10 \mathrm{~mm}$;

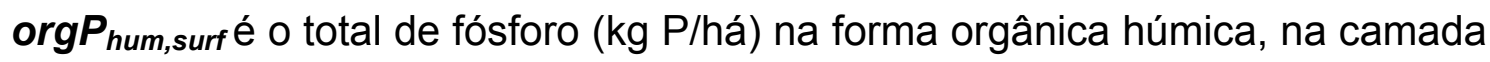
superficial do solo, $10 \mathrm{~mm}$;

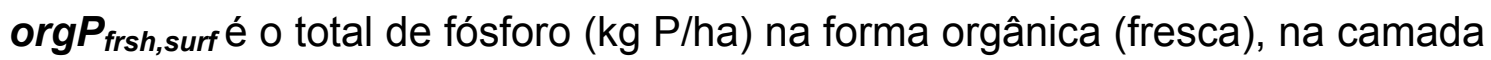
superficial do solo, $10 \mathrm{~mm}$;

$\boldsymbol{\rho}_{b}$ é a densidade $(\mathrm{Mg} / \mathrm{m} 3)$ da primeira camada do solo;

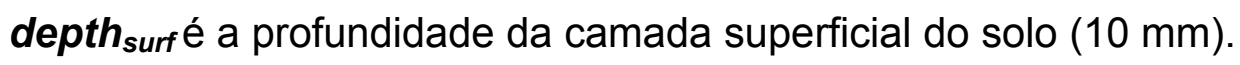

\subsection{Cálculo do volume de dejetos}

$\mathrm{Na}$ microbacia hidrográfica do Rio Bonito, o plantel em confinamento está estimado em $355.500^{8}$ animais, sendo 354.000 aves e 1.500 suínos.

Em decorrência da atividade de confinamento, os dejetos animais apresentam-se concentrados nas granjas, sendo destinados de acordo com o manejo adotado pelo responsável de cada estabelecimento.

Do total de dejetos produzidos, $70 \%$ são exportados para outras microbacias $^{9}$, sendo comprado como fertilizantes. O restante (30\% do volume total produzido) também é utilizado como fertilizante, mas dentro da microbacia em estudo.

\footnotetext{
${ }^{8}$ Informações da Casa da Agricultura, Pecuária e Meio Ambiente de Descalvado, Estado de São Paulo.

${ }^{9}$ Informação da Casa da Agricultura, Pecuária e Meio Ambiente de Descalvado, Estado de São Paulo.
} 


\subsubsection{Aves}

Para a estimativa do volume de dejetos produzidos pelas aves, foi adotada a metodologia proposta por Mitchell Jr et al. (1991) apud Palhares (2004) (Tabela 19).

Considerando-se um ciclo de 45 dias para cada "criada" de aves, a produção de dejetos dá-se em lotes (ou criadas), totalizando 6 ao ano.

Tabela 19. Produção de dejetos por frangos de corte e aves de postura.

\begin{tabular}{|l|c|c|c|}
\cline { 2 - 4 } \multicolumn{1}{c|}{} & Umidade (\%) & Idade (dias) & $\begin{array}{c}\text { Produção de dejetos por } \\
\mathbf{1 . 0 0 0} \text { cabeças (tonelada) }\end{array}$ \\
\hline $\begin{array}{l}\text { Frango de } \\
\text { Corte }\end{array}$ & 20 & $42-49$ & 2,0 \\
\hline $\begin{array}{l}\text { Poedeira } \\
\text { (gaiola) }\end{array}$ & 75 & 365 & $35-44$ \\
\hline
\end{tabular}

Fonte: Micthell Jr et al. (1991). Adaptado de Palhares (2004).

\subsubsection{Suínos}

Para a determinação da produção de dejetos produzidos pela única granja de suínos da microbacia, foi adotada a metodologia proposta por Perdomo et al (1999) apud Palhares (2004), indicada na Tabela 20.

Tabela 20. Volume de efluente produzido, de acordo com o sistema de produção e nível de diluição.

\begin{tabular}{|lccc|}
\hline \multicolumn{1}{|c}{ Sistema de Produção } & \multicolumn{3}{c|}{ Nível de Diluição } \\
\cline { 2 - 4 } & $\begin{array}{c}\text { Pouco } \\
(5,7 \% \text { de } M S)\end{array}$ & $\begin{array}{c}\text { Médio } \\
(3,8 \% \text { de MS })\end{array}$ & $\begin{array}{c}\text { Muito } \\
(2,9 \% \text { de } M S)\end{array}$ \\
\hline $\begin{array}{l}\text { Ciclo Completo (L/matriz) } \\
\begin{array}{l}\text { Unidade Produtora de } \\
\text { Leitões (L/matriz) }\end{array}\end{array}$ & 100 & 150 & 200 \\
$\begin{array}{l}\text { Unidade Terminadora } \\
\text { (L/animal) }\end{array}$ & 70 & 90 & 120 \\
\hline
\end{tabular}


Fonte: PERDOMO et al. (1999)

Foi adotado o índice de 50, levando-se em consideração como sendo "pouco" o nível de diluição dos dejetos produzidos pelos suínos.

No mesmo sentido que para aves, considerou-se a permanência de 30 \% dos dejetos de suínos na MBHRB, uma vez que grande parte é utilizada como alimentação de bovinos, na fase de engorda e na piscicultura, também como fonte de alimento para peixes. As afirmativas referem-se a constatações feitas pelo autor, em visitas de campo.

Considerou-se o número constante de 1.500 animais ao ano, uma vez que não foi possível determinar o número exato de suínos em face de não ter sido possível acessar as fichas de controle da produção da propriedade. Adotou-se, desta forma, uma estimativa com base nas informações da Casa da Agricultura, Pecuária e Meio Ambiente de Descalvado (SP).

\subsection{Cálculo do volume de Nitrogênio (N) e Fósforo (P)}

\subsubsection{Aves}

Para o total de dejetos produzidos por aves, o cálculo do volume de nitrogênio $(\mathrm{N})$ e fósforo $(\mathrm{P})$, em $\mathrm{Kg} / \mathrm{ano}$, foi deduzido conforme metodologia aplicada por Payne e Donald (1991) apud Palhares (2004).

Do volume total de dejetos produzidos por aves, $15 \%$ correspondem ao volume de nitrogênio $(N)$ e 1,6\% correspondem ao volume de fósforo $(P)$, conforme demonstrado pela Tabela 21.

Para os cálculos de nutrientes ( $\mathrm{N}$ e $\mathrm{P}$ ), foram considerados o volume de $30 \%$ do total de dejetos que são produzidos por aves, uma vez que é este volume que permanece na microbacia.

No entanto, devido ao método de armazenamento e manejo (cama de aviários) dos dejetos, considerou-se uma perda de $35 \%$ do nitrogênio $(\mathrm{N})$ total. Adicionalmente, considerou-se uma perda de 5\% para a atmosfera, levando-se 
em consideração o sistema de aplicação no solo (espalhamento sem cultivo). Ambas metodologia foram propostas por Hammond (2001) apud Palhares (2004), demonstrada nas Tabelas 22 e 23.

Tabela 21. Composição da cama de aviário, em porcentagem da matéria seca.

\begin{tabular}{lcc}
\hline Componente & Média & Variação \\
\hline Umidade (\%) & 19,5 & $4,70-39$ \\
Matéria Seca (\%) & 80,5 & $61-95$ \\
Cinzas (\%) & 24,7 & $9-54$ \\
Nitrogênio (\%) & 15,0 & $2,1-6,4$ \\
Fósforo (\%) & 1,6 & $0,56-3,92$ \\
Potássio (\%) & 2,3 & $0,73-5,17$ \\
Cálcio (\%) & 2,3 & $0,81-6,13$ \\
Magnésio (\%) & 0,52 & $0,19-0,88$ \\
Enxofre (\%) & 0,50 & $0,22-0,83$ \\
Cobre (ppm) & 473 & $25-1.000$ \\
Ferro (ppm) & 2.377 & $529-12.604$ \\
Manganês(ppm) & 348 & $125-667$ \\
Zinco (ppm) & 315 & $105-669$ \\
\hline
\end{tabular}

Fonte: Payne e Donald (1991) apud Palhares (2004).

Tabela 22. Perda de nitrogênio ( $N$ ) contido no resíduo, de acordo com o tipo de manejo e armazenamento.

\begin{tabular}{lc}
\hline $\begin{array}{c}\text { Sistema de Manejol } \\
\text { Amazenamento }\end{array}$ & $\begin{array}{c}\text { Perda de Nitrogênio } \\
\text { (\%) }\end{array}$ \\
\hline Ensacamento & 35 \\
Cama de aviário & 35 \\
Resíduo líquido & 0 \\
Fossa anaeróbica & 25 \\
Esterqueira & 60 \\
Lagoa & 80
\end{tabular}


Fonte: Hammond (2001) apud Palhares, (2004)

Tabela 23. Estimativa da perda de nitrogênio $(N)$ contido no resíduo para atmosfera de acordo com o sistema de aplicação no solo.

\begin{tabular}{|c|c|c|}
\hline Sistema de aplicação & Tipo de resíduo & $\begin{array}{l}\text { Perda de nitrogênio* } \\
\text { (\%) }\end{array}$ \\
\hline \multirow{2}{*}{ Espalhamento com cultivo** } & Sólido & 20 \\
\hline & Líquido & 25 \\
\hline \multirow{2}{*}{ Espalhamento sem cultivo } & Sólido & 5 \\
\hline & Líquido & 5 \\
\hline Irrigação & & 30 \\
\hline \multicolumn{3}{|c|}{$\begin{array}{l}\text { * porcentagem do total de nitrogênio }(\mathrm{N}) \text { aplicado que foi perdido, no intervalo de } 4 \text { dias após } \\
\text { a aplicação } \\
\text { ** cultivo imediatamente após a aplicação }\end{array}$} \\
\hline
\end{tabular}

\subsubsection{Suínos}

Em relação ao cálculo de nitrogênio $(N)$ e fósforo $(P)$ relativos ao total de dejetos produzidos por suínos na MBHRB, adotou-se a metologia sugerida por Dartora et al apud Palhares (2004).

Do volume total de dejetos produzidos por suínos, considerou-se que $42 \%$ correspondem ao volume de nitrogênio $(N)$ e $16 \%$ correspondem ao volume de fósforo $(P)$, estimativa que tomou por base as Tabelas 24 e 25.

Para os cálculos de nutrientes ( $\mathrm{N}$ e $\mathrm{P}$ ), foram considerados o volume de $30 \%$ do total de dejetos que são produzidos por suínos, uma vez que é este volume que permanece na microbacia.

Em relação nitrogênio $(\mathrm{N})$ gerado, considerou-se uma perda de 5\% para a atmosfera, em decorrência do sistema de aplicação no solo (Tabela 24). 
Tabela 24. Características dos dejetos líquidos de suínos produzidos por matrizes em ciclo completo, com teor de matéria seca entre 2 e $3 \%$.

\begin{tabular}{lc}
\hline \multicolumn{1}{c}{ Variáveis } & Quantidade (mg/l) \\
\hline Sólidos totais & 25.000 \\
$\mathrm{DBO}_{5}$ & 21.000 \\
Nitrogênio & 3.100 \\
Fósforo & 2.300 \\
Potássio & 1.900
\end{tabular}

Fonte: Dartora et al (1998) apud Palhares (2004)

Tabela 25. Característica do efluente de suínos em função de seu teor de MS.

\begin{tabular}{lccccc}
\hline Grau de diluição & $\begin{array}{c}\mathbf{M S} \\
(\%)\end{array}$ & $\begin{array}{c}\mathbf{D B O}_{5} \\
(\mathbf{m g} / \mathbf{l})\end{array}$ & $\begin{array}{c}\mathbf{N} \\
(\%)\end{array}$ & $\begin{array}{c}\mathbf{P}_{\mathbf{2}} \mathbf{O}_{5} \\
\mathbf{( \% )}\end{array}$ & $\begin{array}{c}\mathbf{K}_{\mathbf{2}} \mathbf{O} \\
(\%)\end{array}$ \\
\hline Concentrado & $5-6$ & 40.000 & 0,49 & 0,48 & 0,31 \\
Semi-concentrado & $4-5$ & 33.000 & 0,44 & 0,41 & 0,28 \\
Semi-diluído & $3-4$ & 27.000 & 0,37 & 0,31 & 0,23 \\
Diluído & $2-3$ & 21.000 & 0,31 & 0,23 & 0,19 \\
Muito diluído & $<2$ & 15.000 & 0,26 & 0,14 & 0,16
\end{tabular}

Fonte: Dartora et al (1998) apud Palhares (2004)

\subsection{Manejo}

Os dados de entrada que geram o arquivo de manejo, são utilizados para especificar as práticas de manejo do solo e da água dentro da bacia no período da simulação (MACHADO, 2003). Esse arquivo contém dados de plantio, colheita, aplicação de irrigação, aplicações de nutrientes e pesticidas e operações de cultivo. Para cada ano de operação de manejo, elas devem ser listadas em ordem cronológica iniciando em janeiro. 
Juntamente com os dados de clima e de solo, o modelo automaticamente simula a proteção oferecida ao solo pelas partes aéreas das plantas (cobertura vegetal ou área foliar) ao longo do ano e, depois de colhida a cultura, a deposição sobre o solo dos restos da cultura após a colheita.

Nesse arquivo foram incluídas as práticas de manejo para as culturas presentes na microbacia. Cada arquivo incluiu operações como plantio, crescimento de plantas, colheita, resíduos após colheita, seqüências de preparo do solo e cultivo, e fertilizantes. Além dessas operações, foram incluídos a data, tipo de operação e quantidade aplicada (fertilizantes). Esses parâmetros de entrada das práticas em uso foram obtidos pela entrevista com engenheiros agrônomos e técnicos da Casa da Agricultura e Meio Ambiente de Descalvado (SP). 


\section{ANÁLISE E DISCUSSÃO DOS RESULTADOS}

\subsection{Divisão da microbacia em sub-bacias e definição das HRUs.}

Os planos de informação (PIs) de uso e ocupação do solo, hidrografia, tipos de solos e curvas de nível interpoladas da microbacia foram inseridos, delineando-se os limites físicos da área em estudo.

Com a entrada no modelo dos Pis, foi possível a identificação das principais características da microbacia quanto ao uso do solo e tipos de solos.

Para o propósito da modelagem, a área assumida pelo AVSWAT foi de $228.759,86$ ha.

Constituindo-se em primeiros resultados, a análise demonstrou haver predomino da cultura da cana-de-açúcar, com $25 \%$ da área total da microbacia, seguida de laranja (21\%) e pastagens $(19 \%)$.

Para os tipos de solos, predominaram o latossolo amarelo (45\%), neossolo quartzarênico $(23 \%)$ e o latossolo vermelho eutroférrico (13\%). Os resultados estão demonstradas nas Tabelas 26 e 27, e Figuras 28 e 29.

Utilizando-se o mapa de curvas de nível interpoladas, em plataforma IDRISI (Figura 30), obteve-se o resultado inaugural: o Modelo de Elevação Digital do terreno (DEM), delineando as feições topográficas da microbacia, representadas pela Figura 31. 
Tabela 26. Usos do solo da MBHRB.

\begin{tabular}{|l|r|}
\hline Tipos de Solos & Área (ha) \\
\hline Cana-de-açúcar & $58.063,08$ \\
\hline Laranja & $48.623,14$ \\
\hline Pastagem & $43.622,67$ \\
\hline Cerrado & $28.855,58$ \\
\hline Mata & $19.454,15$ \\
\hline Agricultura Genérica & $15.369,55$ \\
\hline Área residencial & $11.424,29$ \\
\hline Reflorestamento & $3.233,17$ \\
\hline
\end{tabular}

Tabela 27. Tipos de solos da MBHRB.

\begin{tabular}{|l|r|}
\hline Tipos de Solos & Área (ha) \\
\hline Latossolo Amarelo & $104.616,90$ \\
\hline Neossolo Quartzarênico & $51.581,88$ \\
\hline Latossolo Verm. Eutrof. & $30.600,48$ \\
\hline Latossolo Verm. Mesof. & $18.279,72$ \\
\hline Argissolo & $10.756,52$ \\
\hline Neossolo Litólico & $6.767,13$ \\
\hline Gleissolo & $6.157,24$ \\
\hline
\end{tabular}

Figura 28. Uso do solo da MBHRB.

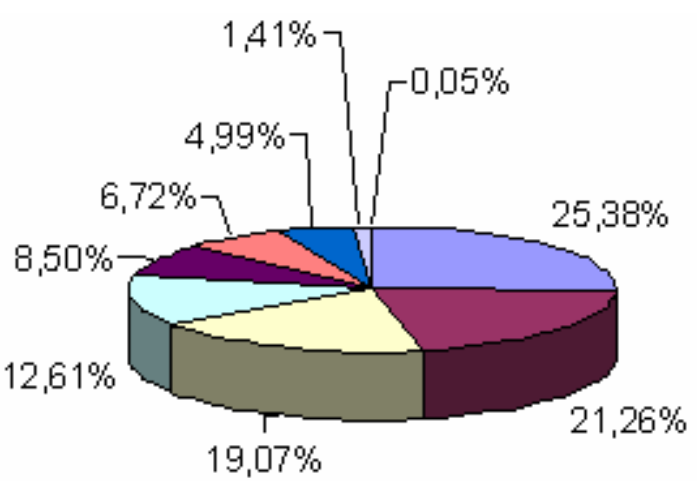

\begin{tabular}{|l|}
\hline$\square$ Cana-de-açúcar \\
$\square$ Laranja \\
$\square$ Pastagem \\
$\square$ Cerrado \\
$\square$ Mata \\
$\square$ Agricultura Genérica \\
$\square$ Área res idencial \\
$\square$ Reflorestamento \\
$\square$ Ága \\
\hline
\end{tabular}

Figura 29. Tipo de solo da MBHRB.

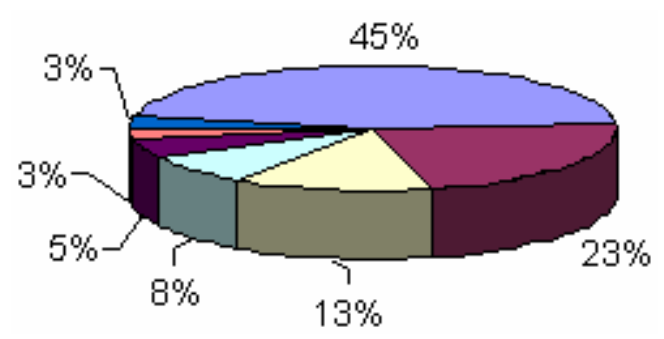

Latossolo Verm. Eutrof. = Latossolo vermelho mesoférrico Eutroférrico

Latossolo Verm. Mesof. = Latossolo vermelho mesoférrico Mesoférrico 


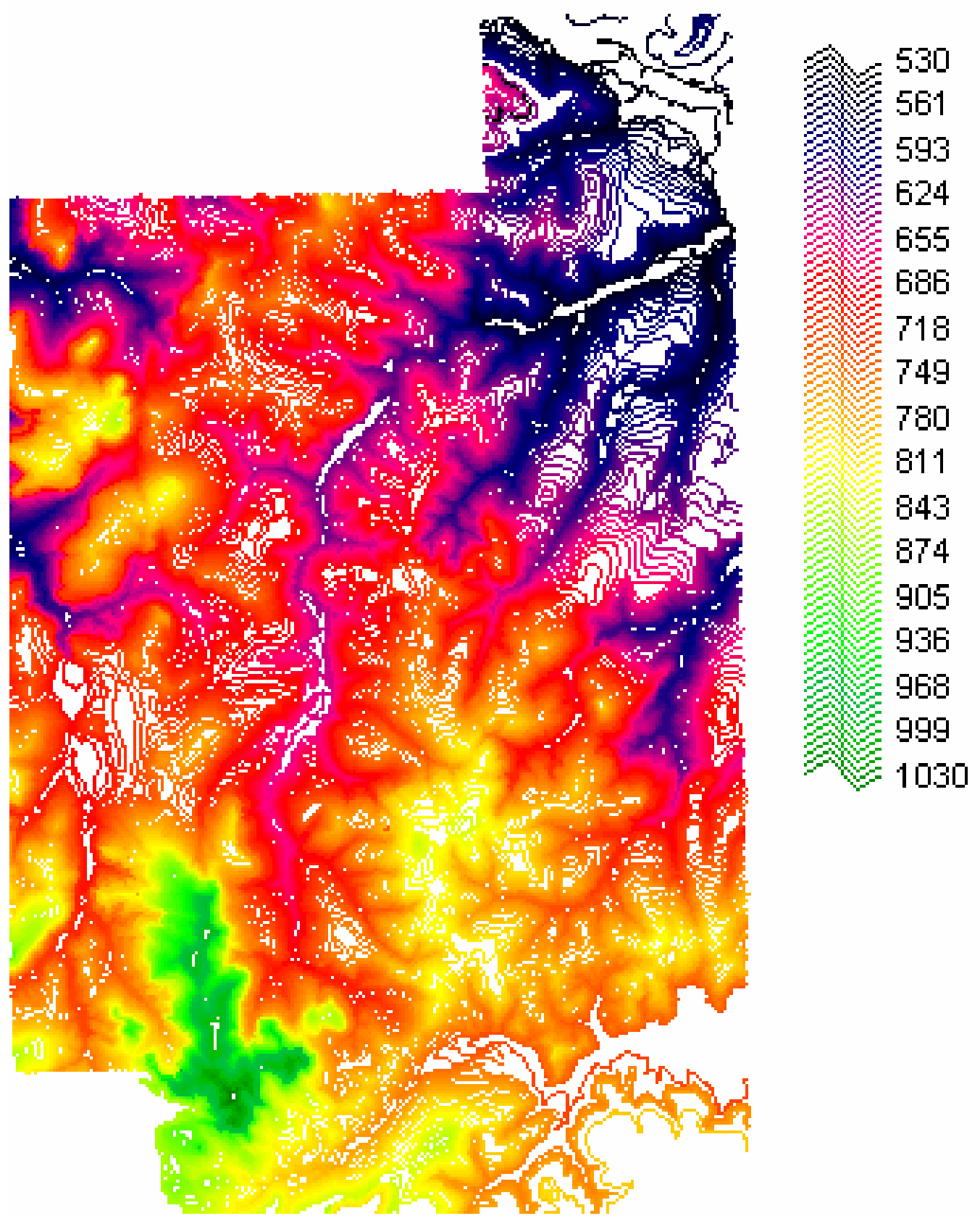

Figura 30. Imagem de curvas de nível interpoladas da microbacia hidrográfica do Rio Bonito (plataforma IDRISI). 


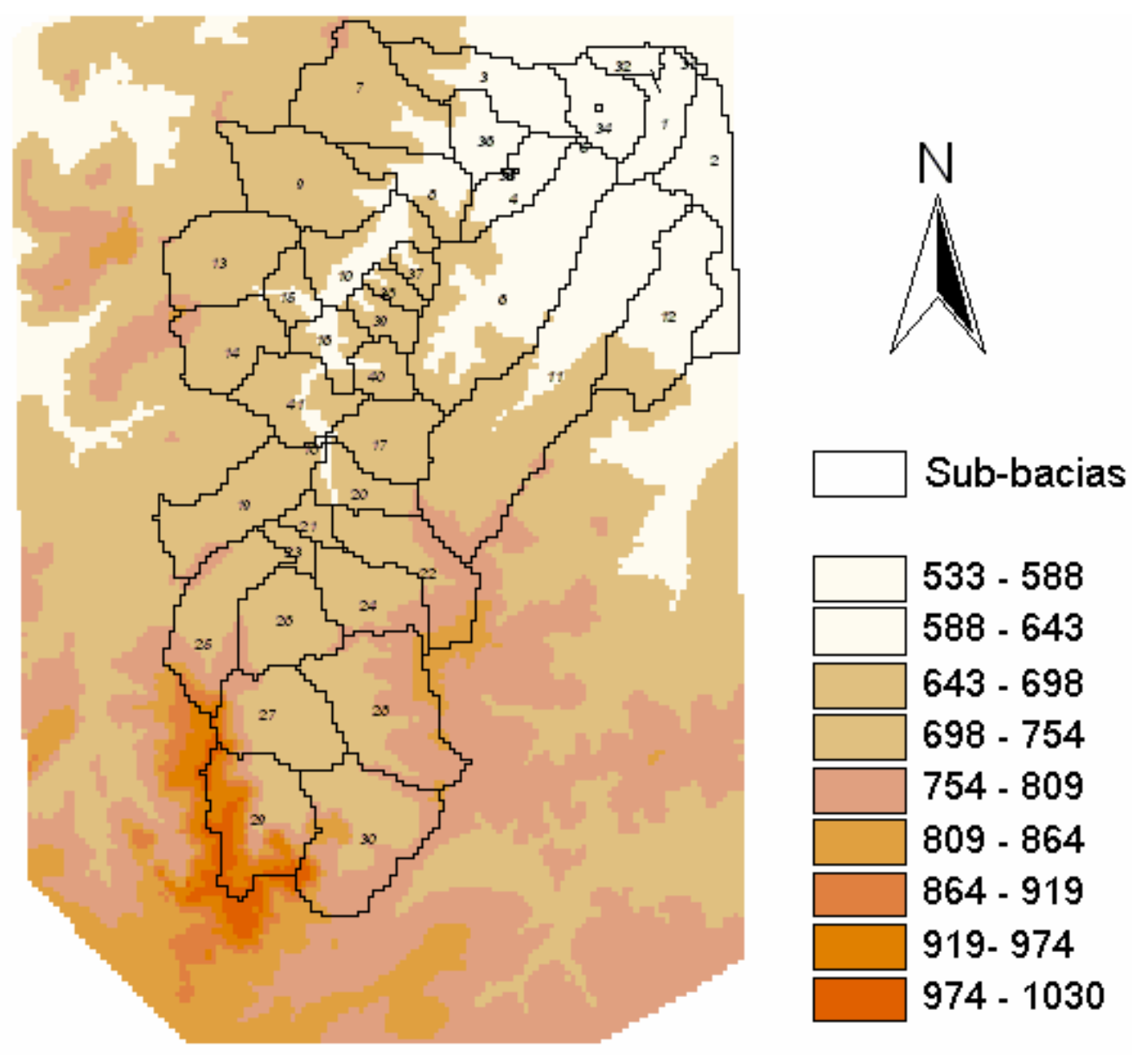

\section{0

Figura 31. Modelo de elevação digital do terreno (DEM), da microbacia hidrográfica do Rio Bonito (AVSWAT).

Na microbacia, a altitude variou entre 533 e 1030 metros, com uma altitude média de 780 metros.

A partir do modelo de elevação digital e da superposição das imagens de solos, uso e ocupação e hidrografia, o modelo AVSWAT realizou a rotina de sub-divisão da microbacia, segundo ao parâmetros sensíveis: uso de solo, tipos de solos e hidrografia, tendo como resultante a sub-divisão da microbacia em 41 sub-bacias (Figura 32). 


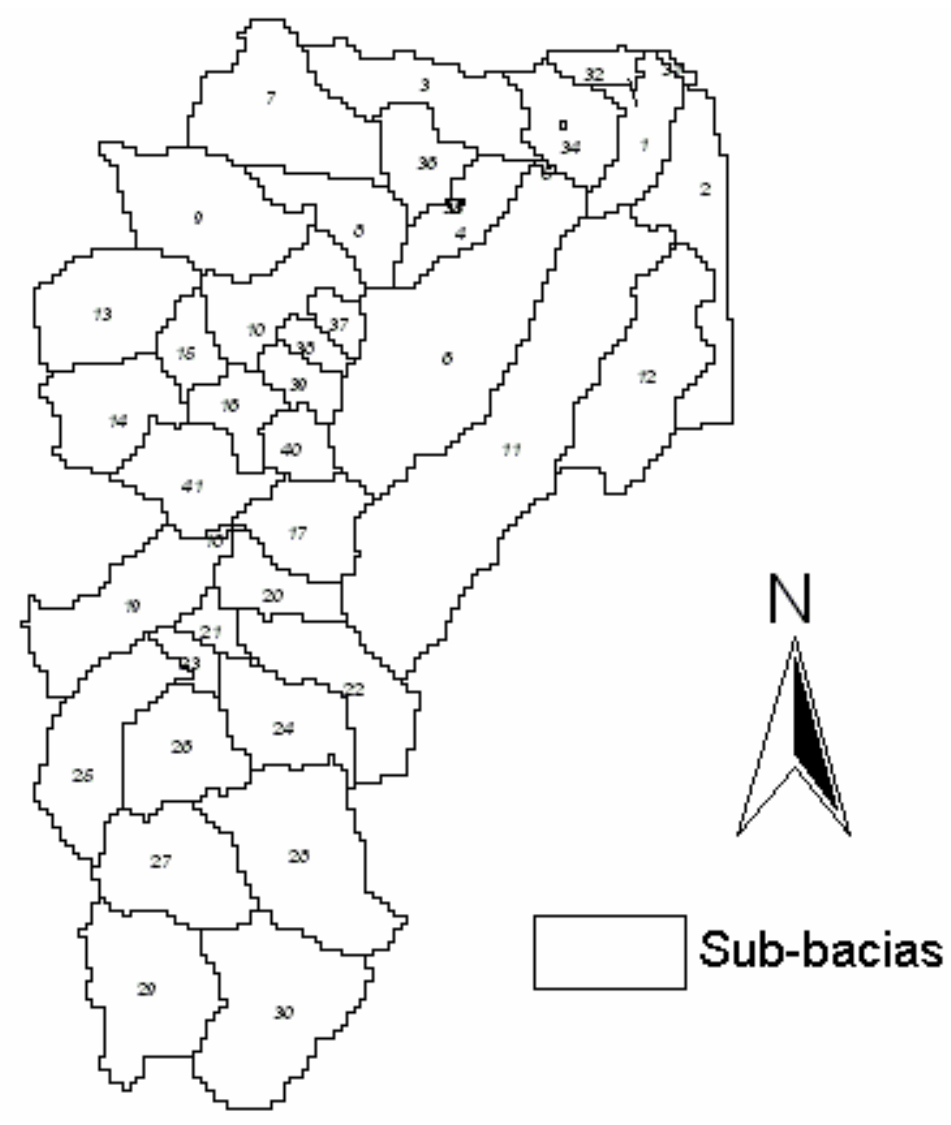

$3000 \quad 0 \quad 3000 \quad 6000 \quad 9000 \quad 12000 \quad 15000 \quad 18000 \quad 21000 \quad 24000$ Meters

Figura 32. Subdivisão da MBHRB em 41 sub-bacias.

Concomitantemente, foi parametrizado, como sensibilidade para determinação das HRUs (Hydrologic Response Units), a hidrografia existente na microbacia. Cada HRU corresponde a uma única combinação de uso da terra-solo-manejo

Foram geradas $628 \mathrm{HRUs}$ para as 41 sub-bacias da MBHRB, as quais podem ser visualizadas e pormenorizadas quanto às suas características no Apêndice I. 


\subsection{Distribuição das granjas nas sub-bacias}

Nos limites territoriais da microbacia hidrográfica do Rio Bonito, as granjas estão distribuídas de forma a apresentarem-se em áreas de concentração, conforme demonstrado pelo georreferenciamento realizado em campo (Tabela 28 e Figura 33).

Os dezenove estabelecimentos identificados e georreferenciados na microbacia compreendem 355.500 animais, sendo 354.000 aves e 1.500 suínos, estes últimos confinados em uma única granja.

A maior concentração de granjas ocorre na sub-bacia 22, compreendendo 5 estabelecimentos que totalizam 86.000 aves. A segunda maior concentração ocorre na sub-bacia 5 , que compreende 5 estabelecimentos, totalizando 54.000 aves.

No entanto, o maior número de animais confinados em uma granja ocorre na sub-bacia 3, na qual estão compreendidas 2 granjas de aves com 30.000 animais em cada uma. Adicionalmente, esta compreendida nesta subbacia, uma granja de suínos com 1.500 animais.

Em relação à distribuição geográfica das granjas, basicamente obedecem ao traçado do canal principal da microbacia. Esse padrão parece remeter à prática de lançamento dos dejetos e efluentes de granjas nos corpos d'água, fato que ainda acomete seriamente a qualidade da água em muitas regiões produtoras, como é o caso do Estado de Santa Catarina e mais recentemente Goiás.

Em visita a campo, notou-se também que a grande concentração de animais em uma parcela territorial, provoca um forte odor de dejetos, alcançando inclusive áreas urbanas, constituindo-se em uma fonte de transtornos para população residente. 
Tabela 28. Georreferenciamento das granjas e plantel de animais.

\begin{tabular}{|c|c|c|c|c|c|c|}
\hline Granja & Animal & $\mathrm{N}^{\circ}$. animais & Sub-bacia & Altitude & \multicolumn{2}{|c|}{ Coordenadas UTM } \\
\hline 1 & aves & 60.000 & 30 & 734 & 230276 & 7562361 \\
\hline 2 & aves & 30.000 & 30 & 711 & 231475 & 7561845 \\
\hline 3 & suínos & 1.500 & 30 & 711 & 231475 & 7561845 \\
\hline 4 & aves & 11.000 & 28 & 711 & 231164 & 7565740 \\
\hline 5 & aves & 40.000 & 22 & 802 & 233569 & 7566885 \\
\hline 6 & aves & 12.000 & 22 & 813 & 234478 & 7567230 \\
\hline 7 & aves & 12.000 & 22 & 796 & 234141 & 7567486 \\
\hline 8 & aves & 12.000 & 22 & 775 & 234164 & 7567814 \\
\hline 9 & aves & 10.000 & 22 & 692 & 231290 & 7569990 \\
\hline 10 & aves & 48.000 & 24 & 690 & 231596 & 7567719 \\
\hline 11 & aves & 30.000 & 20 & 709 & 231439 & 7571036 \\
\hline 12 & aves & 15.000 & 39 & 678 & 231762 & 7575452 \\
\hline 13 & aves & 10.000 & 10 & 647 & 232838 & 7577457 \\
\hline 14 & aves & 10.000 & 10 & 565 & 233117 & 7577544 \\
\hline 15 & aves & 12.000 & 4 & 605 & 235960 & 7578832 \\
\hline 16 & aves & 10.000 & 4 & 604 & 236159 & 7579030 \\
\hline 17 & aves & 12.000 & 4 & 596 & 236321 & 7579236 \\
\hline 18 & aves & 10.000 & 4 & 579 & 236561 & 7579469 \\
\hline 19 & aves & 10.000 & 4 & 565 & 236968 & 7579849 \\
\hline
\end{tabular}




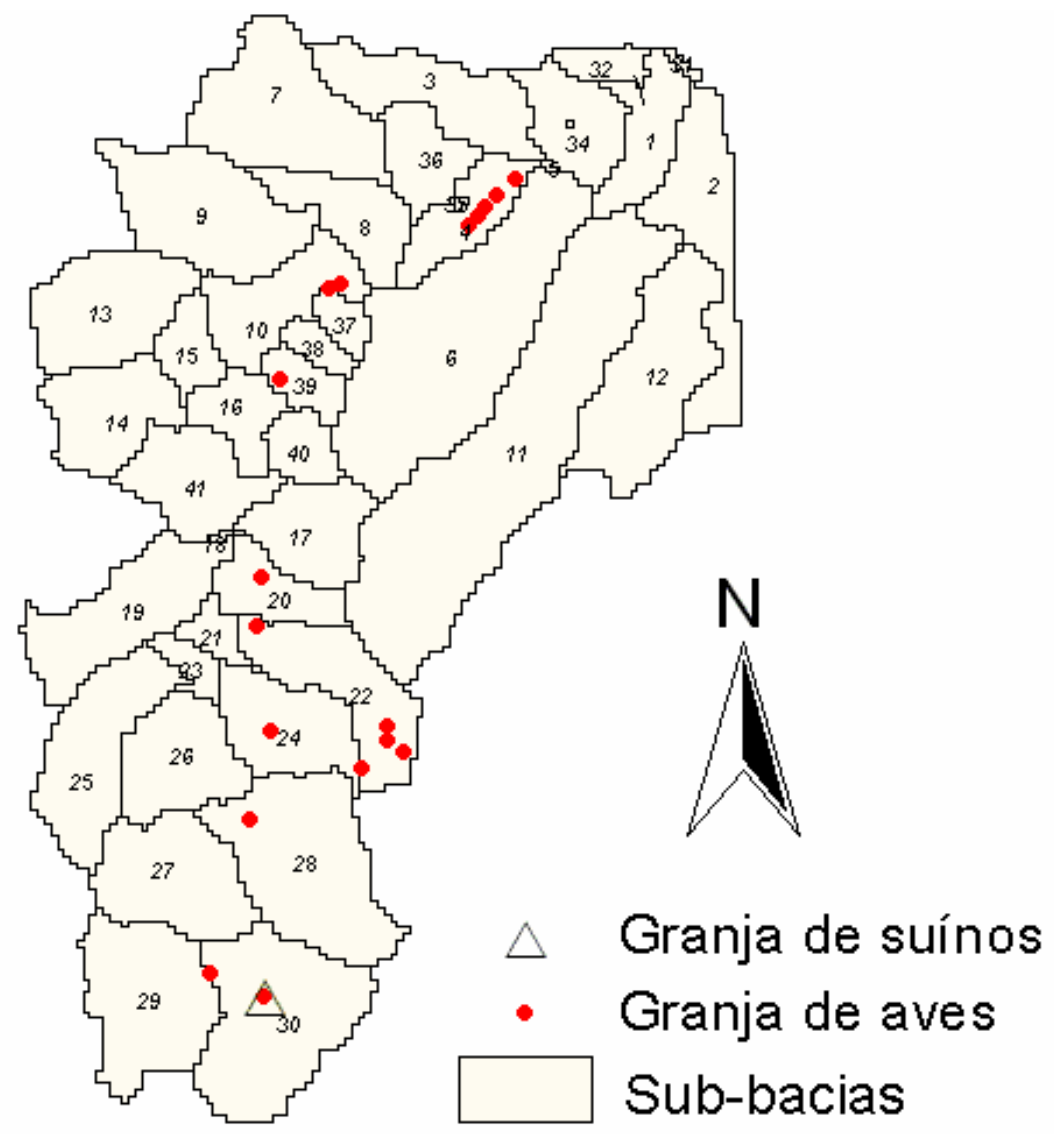

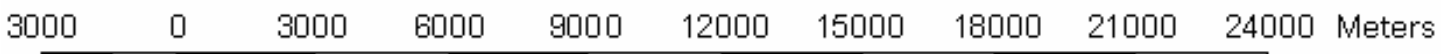

Figura 33. Localização da granjas nas sub-bacias da MBHRB. Georreferenciamento.

A caracterização das sub-bacias que contêm granjas foi realizada pelo modelo AVSWAT conforme o uso do solo e os tipos de solos da área, a qual pode ser demonstrada pelas Tabelas 29, 30, 31 e 32; Figuras 34 e 35. 
Tabela 29. Uso do solo, em hectares, das sub-bacias que compreendem granjas

\begin{tabular}{|c|c|c|c|c|c|c|c|c|c|}
\hline Sub-bacia & $\begin{array}{c}\text { Pastagem } \\
\text { (ha) }\end{array}$ & $\begin{array}{c}\text { Laranja } \\
\text { (ha) }\end{array}$ & $\begin{array}{c}\text { Cana de- } \\
\text { açúcar } \\
\text { (ha) }\end{array}$ & $\begin{array}{c}\text { Agricultura } \\
\text { Genérica } \\
\text { (ha) }\end{array}$ & $\begin{array}{c}\text { Mata } \\
\text { (ha) }\end{array}$ & $\begin{array}{c}\text { Cerrado } \\
\text { (ha) }\end{array}$ & $\begin{array}{c}\text { Refloresta } \\
\text { mento } \\
\text { (ha) }\end{array}$ & $\begin{array}{c}\text { Area } \\
\text { Residencial } \\
\text { (ha) }\end{array}$ & $\begin{array}{c}\text { Água } \\
\text { (ha) }\end{array}$ \\
\hline 4 & $1.251,62$ & 512,96 & $1.169,55$ & 143,63 & 164,15 & 348,81 & 20,52 & 287,26 & 0 \\
\hline 10 & $2.811,02$ & 492,44 & 923,33 & 389,85 & 41,04 & 615,55 & 41,04 & 61,56 & 0 \\
\hline 20 & 615,56 & 533,48 & 984,88 & 615,55 & 123,11 & 389,85 & 20,52 & 0 & 0 \\
\hline 22 & $1.441,67$ & 334,30 & $3.531,05$ & 334,30 & 356,19 & 699,49 & 167,15 & 0 & 0 \\
\hline 24 & 779,70 & 759,18 & $2.318,58$ & 184,67 & 574,52 & 697,63 & 143,63 & 0 & 0 \\
\hline 28 & $1.249,20$ & $6.775,31$ & $1.376,24$ & 211,73 & 456,98 & 868,09 & 317,59 & 0 & 0 \\
\hline 30 & $2.202,64$ & $4.512,20$ & $2.031,56$ & 85,54 & 684,32 & $1.304,48$ & 299,39 & 0 & 21,39 \\
\hline 39 & 564,00 & 348,81 & 389,85 & 102,59 & 0 & 102,59 & 0 & 451,41 & 0 \\
\hline
\end{tabular}

Tabela 30. Uso do solo, em percentual, das sub-bacias que compreendem granjas.

\begin{tabular}{|c|c|c|c|c|c|c|c|c|c|}
\hline Sub-bacia & $\begin{array}{c}\text { Pastagem } \\
(\%)\end{array}$ & $\begin{array}{c}\text { Laranja } \\
(\%)\end{array}$ & $\begin{array}{c}\text { Cana de- } \\
\text { açúcar } \\
(\%)\end{array}$ & $\begin{array}{c}\text { Agricultura } \\
\text { Genérica } \\
(\%)\end{array}$ & $\begin{array}{c}\text { Mata } \\
(\%)\end{array}$ & $\begin{array}{c}\text { Cerrado } \\
(\%)\end{array}$ & $\begin{array}{c}\text { Refloresta } \\
\text { mento } \\
(\%)\end{array}$ & $\begin{array}{c}\text { Area } \\
\text { Residencial } \\
(\%)\end{array}$ & $\begin{array}{c}\text { Água } \\
(\%)\end{array}$ \\
\hline 4 & 32,11 & 13,16 & 30,00 & 3,68 & 4,21 & 8,95 & 0,53 & 7,37 & 0 \\
\hline 10 & 52,29 & 9,16 & 17,18 & 7,25 & 0,76 & 11,45 & 0,76 & 1,15 & 0 \\
\hline 20 & 18,75 & 16,25 & 30,00 & 18,75 & 3,75 & 11,88 & 0,62 & 0 & 0 \\
\hline 22 & 21,04 & 4,88 & 51,52 & 4,88 & 5,18 & 10,06 & 2,44 & 0 & 0 \\
\hline 24 & 14,29 & 13,91 & 42,48 & 3,38 & 10,53 & 12,78 & 2,63 & 0 & 0 \\
\hline 28 & 11,07 & 60,04 & 12,20 & 1,88 & 4,32 & 7,69 & 2,81 & 0 & 0 \\
\hline 30 & 19,77 & 40,50 & 18,23 & 0,77 & 6,14 & 11,71 & 2,69 & 0 & 0,19 \\
\hline 39 & 28,42 & 17,89 & 20,00 & 5,26 & 0 & 5,26 & 0 & 23,16 & 0 \\
\hline
\end{tabular}

Tabela 31. Tipos de solos, em hectares, das sub-bacias que compreendem granjas.

\begin{tabular}{|c|c|c|c|c|c|c|c|}
\hline Sub-bacia & $\begin{array}{c}\text { Latossolo } \\
\text { Amarelo } \\
\text { (ha) }\end{array}$ & $\begin{array}{c}\text { L atos. Verm. } \\
\text { Eutroferrico } \\
\text { (ha) }\end{array}$ & $\begin{array}{c}\text { L atos. Verm. } \\
\text { Mesofirmico } \\
\text { (ha) }\end{array}$ & $\begin{array}{c}\text { Argissolo } \\
\text { (ha) }\end{array}$ & $\begin{array}{c}\text { Gleissolo } \\
\text { (ha) }\end{array}$ & $\begin{array}{c}\text { Neossolo } \\
\text { Litólico } \\
\text { (ha) }\end{array}$ & $\begin{array}{c}\text { Neossolo } \\
\text { Quatzarênico } \\
\text { (ha) }\end{array}$ \\
\hline 4 & $2.934,13$ & 636,07 & 0 & 164,15 & 164,15 & 0 & 0 \\
\hline 10 & $3.180,36$ & 0 & 0 & 0 & 923,33 & 800,22 & 471,92 \\
\hline 20 & 123,11 & 61,56 & $1.272,14$ & 0 & 471,92 & 0 & $1.354,22$ \\
\hline 22 & 0 & 814,86 & $3.280,32$ & 0 & 125,36 & 0 & $2.632,61$ \\
\hline 24 & 0 & $1.538,88$ & $1.066,96$ & 0 & 41,04 & 0 & $2.811,02$ \\
\hline 28 & $7.728,09$ & 529,32 & 846,91 & 0 & 0 & 0 & $2.180,80$ \\
\hline 30 & $9.623,18$ & 513,24 & 0 & 0 & 0 & $1.005,09$ & 0 \\
\hline 39 & $1.949,25$ & 0 & 0 & 0 & 0 & 0 & 0 \\
\hline
\end{tabular}

Tabela 32. Tipos de solos, em percentual, das sub-bacias que compreendem granjas

\begin{tabular}{|c|c|c|c|c|c|c|c|}
\hline Sub-bacia & $\begin{array}{c}\text { Latossolo } \\
\text { Amarelo } \\
(\%)\end{array}$ & $\begin{array}{c}\text { L ztos. Verm. } \\
\text { Eutroferrico } \\
(\%)\end{array}$ & $\begin{array}{c}\text { L ztos. Verm. } \\
\text { Mesoferrico } \\
(\%)\end{array}$ & $\begin{array}{c}\text { Argissolo } \\
(\%)\end{array}$ & $\begin{array}{c}\text { Gleissolo } \\
(\%)\end{array}$ & $\begin{array}{c}\text { Neossolo } \\
\text { Litólico } \\
(\%)\end{array}$ & $\begin{array}{c}\text { Neossolo } \\
\text { Quatzarênico } \\
(\%)\end{array}$ \\
\hline 4 & 75,20 & 10,32 & 0 & 4,21 & 4,21 & 0 & 0 \\
\hline 10 & 50,10 & 0 & 0 & 0 & 17,18 & 14,80 & 8,78 \\
\hline$\not 0$ & 3,75 & 1,87 & 38,75 & 0 & 14,38 & 0 & 41,25 \\
\hline 22 & 0 & 11,80 & 47,87 & 0 & 1,83 & 0 & 38,41 \\
\hline 24 & 0 & 28,20 & 19,55 & 0 & 0,75 & 0 & 51,50 \\
\hline 28 & 08,48 & 4,00 & 7,50 & 0 & 0 & 0 & 19,32 \\
\hline 30 & 80,37 & 4,01 & 0 & 0 & 0 & 0,02 & 0 \\
\hline 39 & 100 & 0 & 0 & 0 & 0 & 0 & 0 \\
\hline
\end{tabular}


Sub-bacia 4

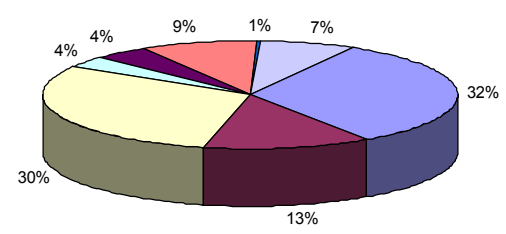

Sub-bacia 20

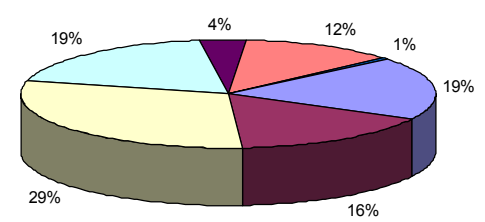

Sub-bacia 24

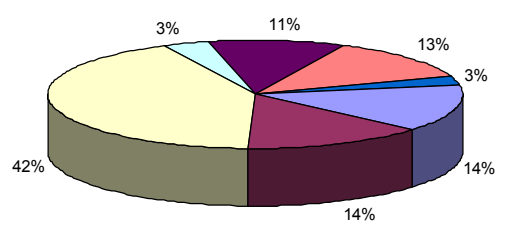

Sub-bacia 30

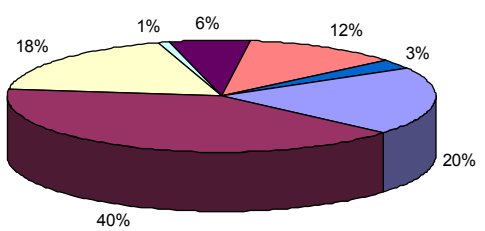

Sub-bacia 10

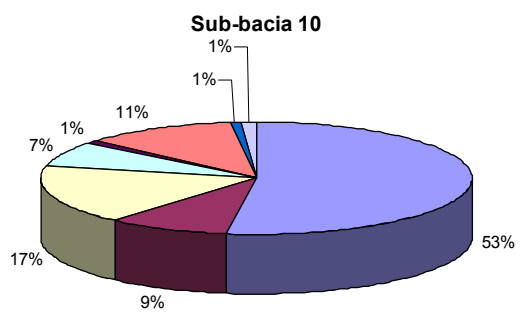

Sub-bacia 22

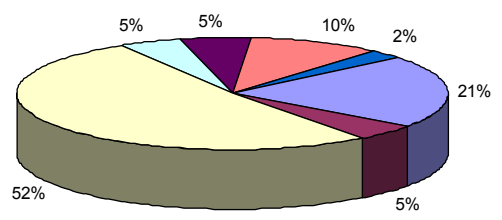

Sub-bacia 28

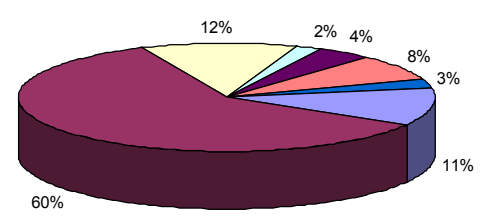

Sub-bacia 39

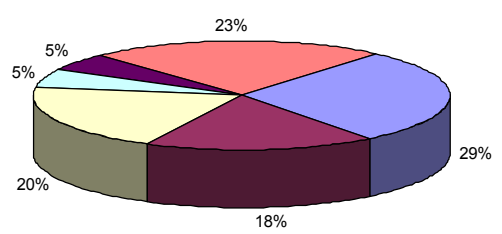

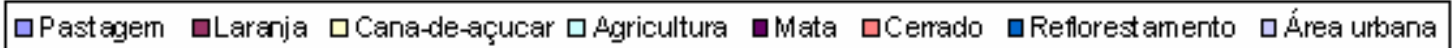

Figura 34. Uso do solo, em percentual, das sub-bacias que compreendem granjas. 
Sub-bacia 4

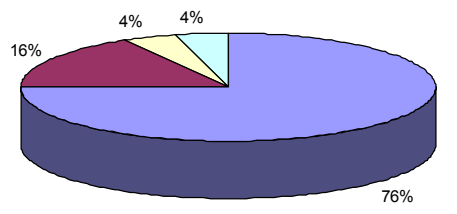

Sub-bacia 10

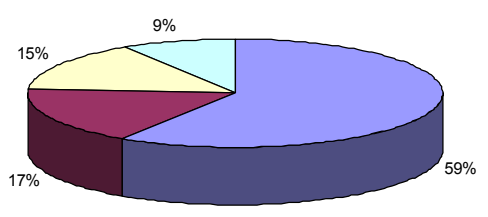

Sub-bacia 20

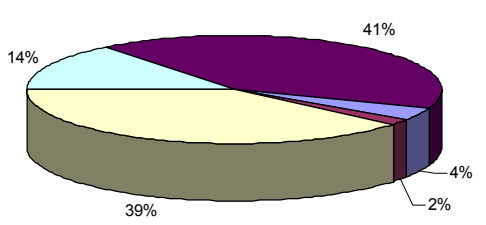

Sub-bacia 22

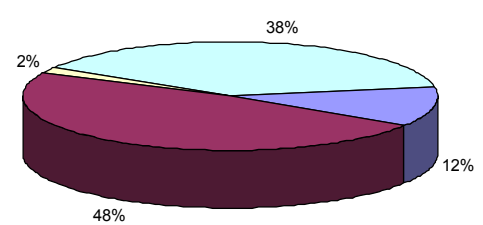

Sub-bacia 24

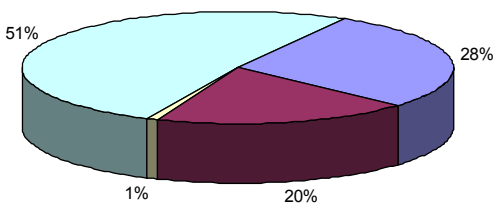

Sub-bacia 28

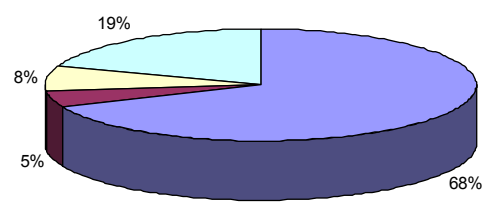

Sub-bacia 30

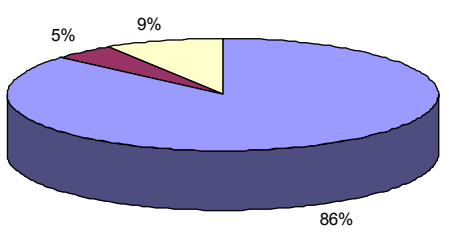

Sub-bacia 39

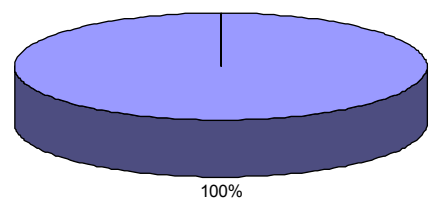

口Latossolo Amarelo uLatossolo Roxo aLatossolo Vemelho uGleissolo a Necssolo Quat zarênico

Figura 35. Tipos de solos, em percentual, das sub-bacias que compreendem granjas. 
Nas sub-bacias que contêm granjas, o predomínio para solo é para o tipo latossolo amarrelo, seguido de neossolo quartzarênico e latossolo vermelho mesoférrico mesoférrico.

Em relação ao uso do solo, predomina a cana-de-açúcar, seguida de laranja e pastagens.

Este conjunto de 8 sub-bacias, nas quais se inserem as granjas, são bons indicadores, em termos de erosão, para o restante da microbacia, uma vez que há equivalência quase absoluta dos predomínios de solos e usos do solo.

\subsection{Volume de dejetos animais nas sub-bacias que contêm granjas.}

\subsubsection{Aves}

Para os cálculos do volume de dejetos de aves, levou-se em consideração o volume gerado em cada granja, obedecendo-se um ciclo anual de atividades.

Cada ciclo anual pode contemplar até seis "criadas" (ciclos) de vida das aves, ou seja, da fase jovem à adulta, até a fase de terminação e abate.

Para os seis ciclos de "criadas" de aves, os dejetos produzidos pelas aves totalizaram $4.248 .000 \mathrm{Kg}$, dos quais $1.274 .400 \mathrm{Kg}(30 \%$ do total) permaneceram na microbacia em estudo, sendo utilizados como fertilizantes, conforme informações obtidas na Casa da Agricultura, Pecuária e Meio Ambiente de Descalvado (SP).

Não há um controle, entre os produtores na microbacia, do total de dejetos gerados e sua destinação. Por esse motivo, os cálculos são estimados, segundo protocolos e metodologias adotados da literatura disponível. 
A Tabela 33 resume a produção total de dejetos por aves, na microbacia.

Tabela 33. Produção de dejetos por aves e o percentual de utilização na MBHRB.

\begin{tabular}{|c|r|r|r|r|}
\cline { 3 - 5 } \multicolumn{2}{c|}{} & \multicolumn{3}{c|}{ KG DE DEJETO / ANO } \\
\hline Sub-bacia & No. de aves & $\begin{array}{c}\text { Dejetos } \\
\text { produzidos }\end{array}$ & $30 \%$ (fica na MBH) & $70 \%$ (sai da MBH) \\
\hline 4 & 54.000 & 648.000 & 194.400 & 453.600 \\
\hline 10 & 20.000 & 240.000 & 72.000 & 168.000 \\
\hline 20 & 30.000 & 360.000 & 108.000 & 252.000 \\
\hline 22 & 86.000 & 1.032 .000 & 309.600 & 722.400 \\
\hline 24 & 48.000 & 576.000 & 172.800 & 403.200 \\
\hline 28 & 11.000 & 132.000 & 39.600 & 92.400 \\
\hline 30 & 90.000 & 1.080 .000 & 324.000 & 756.000 \\
\hline 39 & 15.000 & 180.000 & 54.000 & 126.000 \\
\hline
\end{tabular}

\begin{tabular}{|l|r|r|r|r|}
\hline Totalizadores & $2.124 .000^{*}$ & 4.248 .000 & 1.274 .400 & 2.973 .600 \\
\hline
\end{tabular}

* somatório de aves de todos estabelecimentos das sub-bacias, multiplicado por 6 (6 criadas por ano).

Os estabelecimentos que mais produziram dejetos foram aqueles concentrados e situados nas sub-bacias, em ordem de grandeza de produção: $30,22,4,24$ e 20 seguidos dos outros estabelecimentos.

Os cálculos de produção de dejetos não levaram em consideração aspectos da flutuação na produção de aves, tais como doenças, queda de temperatura, elevação da temperatura e outros fatores que afetam o equilíbrio da produção.

Considerou-se, neste sentido, a produção constante de aves com a geração de dejetos na capacidade total do plantel.

\subsubsection{Suínos}

Para suínos, os cálculos do volume de dejetos gerados obedeceram a literatura disponível. 
O total de dejetos produzidos, por ano, foi de $75.000 \mathrm{Kg}$, dos quais $30 \%$ permaneceram na microbacia, ou seja: $22.500 \mathrm{Kg}$. A Tabela 34 representa a produção total de dejetos por suínos, na microbacia.

Tabela 34. Produção total de dejetos, por suínos, e o percentual de utilização na MBHRB.

\begin{tabular}{|c|c|r|r|r|}
\cline { 3 - 5 } \multicolumn{2}{c|}{} & \multicolumn{3}{c|}{ KG DE DEJETO / ANO } \\
\hline Sub-bacia & $\begin{array}{l}\text { No. de } \\
\text { suínos }\end{array}$ & Dejetos produzidos & $30 \%$ (fica na MBH) & 70\% (sai da MBH) \\
\hline 30 & $\mathbf{1 . 5 0 0}$ & $\mathbf{7 5 . 0 0 0}$ & $\mathbf{2 2 . 5 0 0}$ & $\mathbf{5 2 . 5 0 0}$ \\
\hline
\end{tabular}

Embora o número de suínos fosse muito inferior ao de aves, em termos absolutos, foi importante determinar o volume de dejetos gerados, uma vez que a composição dos mesmos difere substancialmente, em nível de nitrogênio $(\mathrm{N})$ e fósforo $(P)$, em relação ao dejeto de aves.

A premissa maior da importância da determinação do volume de dejetos gerados nesta única granja foi o fato deste estabelecimento estar instalado em área muito próxima ao leito do rio, constituindo-se em uma provável fonte de poluição pontual.

Residiu no questionamento desta circunstância, a justificativa plausível para a manutenção desta única granja de suínos no presente estudo.

\subsection{Volume de Nitrogênio (N) e Fósforo (P), em função dos dejetos gerados, nas sub-bacias que contêm granjas.}

Decorrente dos dejetos de aves gerados nas diferentes granjas da microbacia calculou-se o volume de nutrientes $(N)$ e Fósforo $(P)$ levando-se em consideração a metodologia descrita no item 4.4.8.

$\mathrm{Na}$ determinação do volume de nitrogênio $(\mathrm{N})$ nos dejetos de aves gerados em cada sub-bacia, deduziu-se $35 \%$ do volume do nutriente, relativo à 
perda em função do sistema de manejo do dejeto (cama de aviários). Os resultados desta etapa estão tabulados na Tabela 35.

Tabela 35. Volume de nitrogênio $(N)$ e fósforo $(P)$ gerados em função dos dejetos totais de aves. Resultado considerando dedução de (35\%) de nitrogênio (N).

\begin{tabular}{|c|c|c|c|}
\hline \multirow{2}{*}{ Sub-bacia } & \multirow[b]{2}{*}{ No. de aves } & \multicolumn{2}{|c|}{ KG NUTRIENTE / ANO } \\
\hline & & Fósforo $(P)$ & Nitrogênio $(\mathrm{N})$ \\
\hline 4 & 54000 & 3110,40 & 18954,00 \\
\hline 10 & 20000 & 1152,00 & 7020,00 \\
\hline 20 & 30000 & 1728,00 & 10530,00 \\
\hline 22 & 86000 & 4953,60 & 30186,00 \\
\hline 24 & 48000 & 2764,80 & 16848,00 \\
\hline 28 & 11000 & 633,60 & 3861,00 \\
\hline 30 & 90000 & 5184,00 & 31590,00 \\
\hline 39 & 15000 & 864,00 & 5265,00 \\
\hline \multicolumn{2}{|c|}{ Totalizadores } & $20.390,40$ & $124.254,00$ \\
\hline
\end{tabular}

Igualmente, para os dejetos gerados na única granja de suínos, situada na sub-bacia 30, o volume de nitrogênio $(N)$ e fósforo $(P)$ foi determinado de acordo com a metodologia adotada. Os resultados seguem-se na Tabela 36.

Tabela 36. Volume de nitrogênio $(N)$ e fósforo $(P)$ gerados em função dos dejetos totais de suínos.

\begin{tabular}{|c|c|c|c|}
\cline { 3 - 4 } \multicolumn{2}{c|}{} & \multicolumn{2}{c|}{ Kg NUTRIENTE / ANO } \\
\hline Sub-bacia & No. de suínos & Fósforo $(\mathrm{P})$ & Nitrogênio $(\mathrm{N})$ \\
\hline 30 & 1500 & $\mathbf{1 3 1 4 , 0 0}$ & $\mathbf{3 4 4 9 , 2 5}$ \\
\hline
\end{tabular}

Para finalização dos cálculos do volume de nitrogênio $(\mathrm{N})$ e fósforo $(\mathrm{P})$, deduziu-se $5 \%$ do volume de nitrogênio $(N)$, inicialmente determinado, em função da perda deste elemento, por volatilização, para a atmosfera, decorrente do espalhamento dos dejetos na microbacia. Esta dedução foi considerada tanto para o volume inicial de nitrogênio $(\mathrm{N})$ gerado pelos dejetos de aves quanto pelos dejetos de suínos. 
$O$ volume de fósforo $(\mathrm{P})$ permaneceu inalterado, pois a metodologia adotada não descreveu perdas para este elemento. A Tabela 37 demonstra os resultados.

Tabela 37. Volume final de nitrogênio $(N)$ e fósforo $(P)$ gerados em função dos dejetos totais de aves. Resultado final considerando uma perda adicional de $5 \%$ de nitrogênio $(N)$.

\begin{tabular}{|c|c|c|}
\cline { 2 - 3 } \multicolumn{1}{c|}{} & \multicolumn{2}{c|}{ ESPALHAMENTO } \\
\hline Sub-bacia & $\begin{array}{c}\text { P kg/ano } \\
\text { (aves) }\end{array}$ & $\begin{array}{c}\text { N kg/ano } \\
\text { (aves) }\end{array}$ \\
\hline 4 & 3110,40 & 18006,30 \\
\hline 10 & 1152,00 & 6669,00 \\
\hline 20 & 1728,00 & 10003,50 \\
\hline 22 & 4953,60 & 28676,70 \\
\hline 24 & 2764,80 & 16005,60 \\
\hline 28 & 633,60 & 3667,95 \\
\hline 30 & 6498,00 & 33287,29 \\
\hline 39 & 864,00 & 5001,75 \\
\hline Totalizadores & $\mathbf{2 1 7 0 4 , 4 0}$ & $\mathbf{1 2 1 3 1 8 , 0 9}$ \\
\cline { 2 - 3 } & &
\end{tabular}

\subsection{Distribuição do nitrogênio $(N)$ e fósforo $(P)$ nas sub-bacias que contêm} granjas.

O modelo AVSWAT considera a entrada de dados de fertilizantes por mês, fato que determinou que os valores finais de nitrogênio $(N)$ e fósforo $(P)$, demonstrados pela Tabela 38 fossem divididos por 12 e o resultado representasse a fertilização do solo de maneira homogênea entre os meses do ano (Tabela 38).

Tabela 38. Dados de entrada mensais do módulo de fertilizantes do AVSWAT.

\begin{tabular}{|c|c|c|}
\cline { 2 - 3 } \multicolumn{1}{c|}{} & \multicolumn{2}{c|}{ KG NUTRIENTE / MÊS } \\
\hline sub-bacia & Fósforo $(\mathrm{P})$ & Nitrogênio $(\mathrm{N})$ \\
\hline 4 & 259,2 & 1500,52 \\
\hline 10 & 96 & 555,75 \\
\hline 20 & 144 & 833,62 \\
\hline 22 & 412,8 & 2389,72 \\
\hline 24 & 230,4 & 1333,8 \\
\hline 28 & 52,8 & 305,66 \\
\hline 30 & 541,5 & 2773,94 \\
\hline 39 & 72 & 416,81 \\
\hline \multirow{2}{*}{ Totalizadores } & $\mathbf{1 8 0 8 , 7}$ & $\mathbf{1 0 1 0 9 , 8 4}$ \\
\cline { 2 - 3 }
\end{tabular}


A adoção dessa metodologia de entrada de dados de nutrientes não influenciou nos resultados de simulação do modelo, uma vez que foram parametrizadas em anuais.

Desta forma, para o propósito da modelagem dos dados de fertilizantes, a entrada dos valores foi realizada por cada HRU em cada sub-bacia onde havia presença de granja, ou seja, o volume total de dejeto gerados na subbacia foi proporcionalmente distribuído em cada HRU desta mesma sub-bacia.

Para satisfação da unidade de entrada requerida pelo modelo (valores de entrada de fertilizantes expressos em kilograma por hectare - $\mathrm{Kg} / \mathrm{ha}$ ), o volume total de nutrientes, para cada sub-bacia, foi dividido pela área de suas respectivas HRUs, resultando-se expressos em Kg/ha.

Em sub-bacias onde há presença de mais de uma granja, os valores relativos ao volume de nutrientes gerados em cada estabelecimento foram somados e distribuídos pelas HRUs desta mesma sub-bacia.

Neste sentido, os valores de entrada de nutrientes para cada HRU, nas sub-bacias $4,10,20,22,24,28,30$ e 39, onde há presença de granjas, estão representados no Apêndice II.

Em cada sub-bacia que contêm granjas, o fator determinador da concentração de nitrogênio $(N)$ e fósforo $(P)$ foi sua área correspondente.

Em ordem decrescente de grandeza, as sub-bacias que apresentaram maior concentração de nitrogênio $(N)$ e fósforo $(P)$ foram a 4, 22, 20, 24 e 30 , 39,10 e 28, conforme demonstra a Figura 36. 


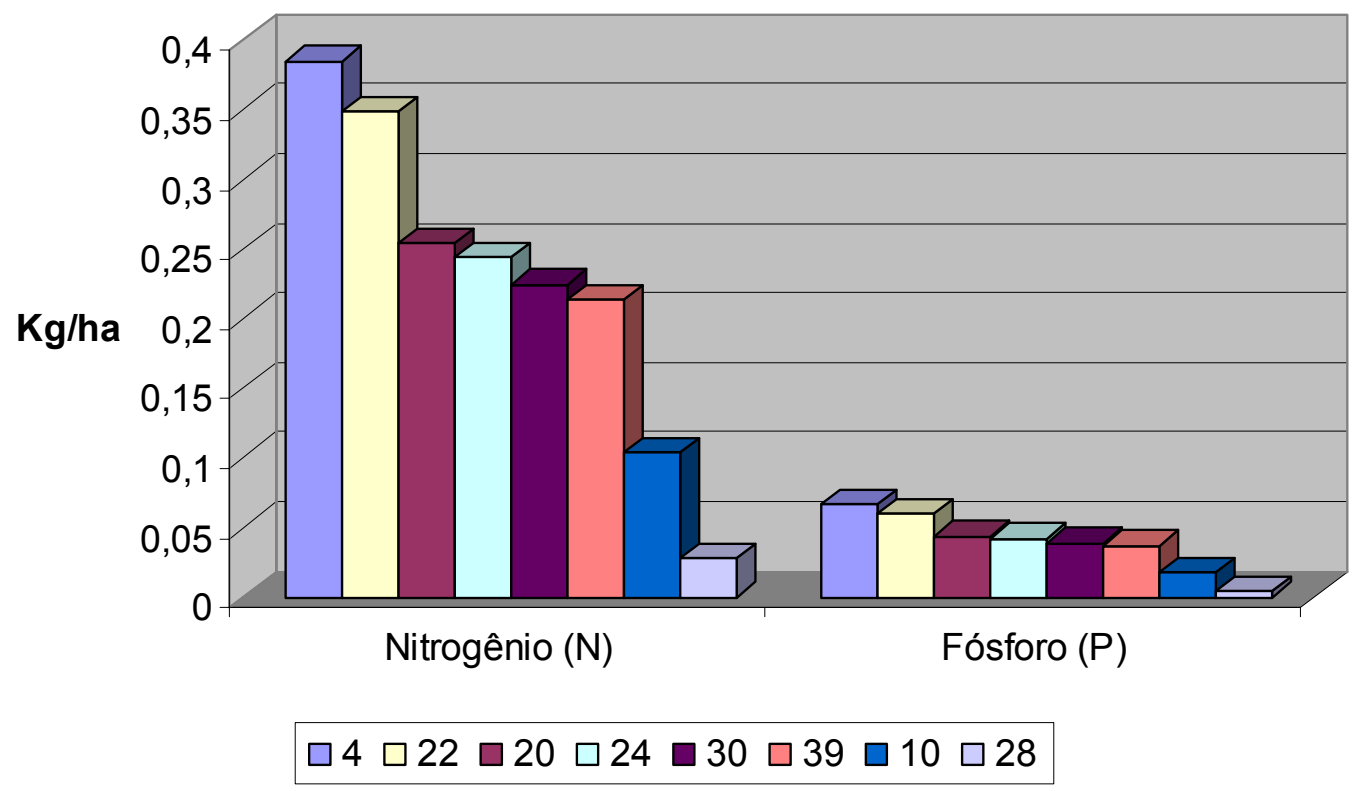

Figura 36. Concentração de nitrogênio $(N)$ e fósforo $(P)$ em cada sub-bacia que contêm granja.

\subsection{Simulações}

Cumprida a etapa de entrada de dados no modelo, iniciou-se a fase de geração de rotinas e simulações. A Figura 37 ilustra os procedimentos.

As simulações no modelo AVSWAT foram conduzidas a fim de se responder as principais perguntas da pesquisa: (i) quais são as áreas geradoras de sedimentos na microbacia; (ii) qual volume de sedimentos e nutriente chega aos mananciais da microbacia; (iii) quais são as áreas que contribuem para a poluição dos mananciais. 


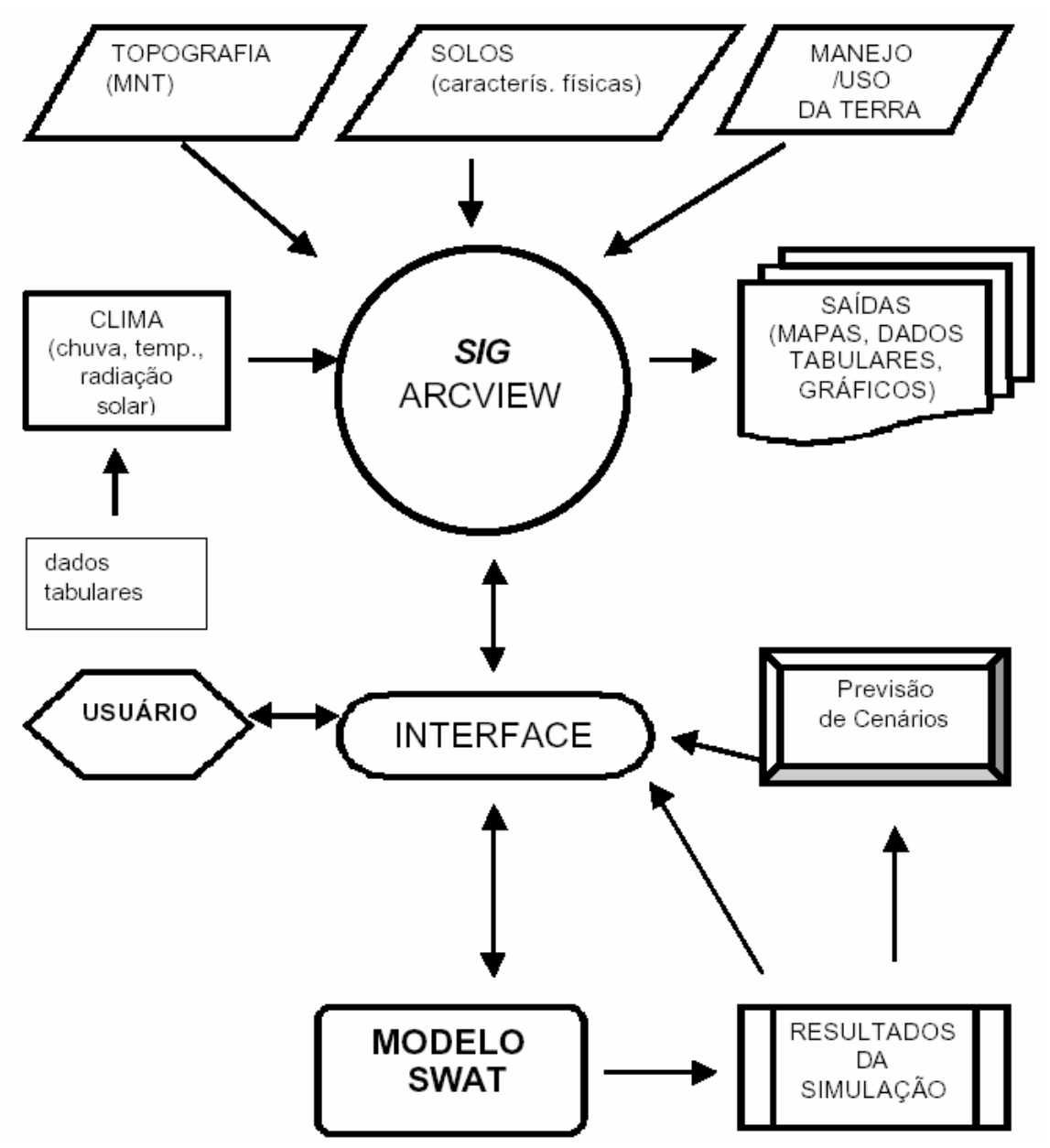

Figura 37. Procedimentos para geração da base de dados e simulações do modelo SWAT via SIG.

Fonte: Adaptado de Machado, 2003

Dentre os inúmeros dados de entrada requeridos pelo AVSWAT, destacam-se alguns que sensibilizam o modelo, como dados de clima, dados específicos sobre cada cultura, manejo, dados sobre água subterrânea (aqüífero raso e profundo), escolha do método de evapotranspiração e principalmente a determinação da Curva Número, a qual é responsável pelo escoamento superficial em cada sub-bacia.

Inicialmente, adotaram-se os valores para $\mathrm{CN}$ informados pelo Serviço de Conservação de Solos (SCS), do Departamento de Agricultura dos Estados Unidados (USDA), em face do modelo ser de origem norte americana e também pelos trabalhos disponíveis na literatura, com modelagem e utilização 
do AVSWAT, terem contemplado o uso da CN e grupos hidrológicos propostos para os solos norte americanos.

No entanto, definiu-se utilizar os grupos hidrológicos propostos por Lombardi Neto (1989), cuja classificaçào dos grupos hidrológicos dos solos brasileiro pode parametrizar a classificação dos solos da microbacia em sendo do grupo hidrológico A os solos Latossolo vermelho mesoférrico mesoférrico, Latossolo vermelho eutroférrico e Latossolo amarelo; grupo hidrológico B os solos Latossolo vermelho eutroférrico e Neossolo quartzarênico; grupo hidrológico C o solo Argissolo e grupo hidrológico D os solos Neossolo litólico e Gleissolo.

Para manejo, adotou-se:

a) Pastagem: degradada; presença de compactação superficial, utilização de queimadas e até $25 \%$ da área sem vegetação, mesmo no período chuvoso;

b) Agricultura genérica: culturas anuais; planto em nível ou contorno; resíduo cultural na superfície $>5 \mathrm{t} / \mathrm{ha}$;

c) Laranja: culturas perenes; plantio em nível ou contorno;

d) Cana-de-açúcar: culturas temporárias; plantio em nível ou contorno; resíduo cultural na superfície $>5$ t/ha;

e) Mata: vegetação natural

f) Reflorestamento: plantio em nível ou contorno; resíduo cultural na superfície > 5 t/ha;

g) Cerrado: vegetação característica

Uma vez que houve uma adaptação da $\mathrm{CN}$ para usos agrícolas no Brasil, principalmente sobre as definições dos tipos de culturas e manejos agrícolas (SARTORI, 2004), adotou-se estas definições numéricas, que foram baseadas nos resultados dos trabalhos de Silva (1996) e Lombardi Neto (não publicado), e também nos próprios valores do CN da tabela do SCS.

A Tabela 39 demonstra os valores CN para cada grupo hidrológico dos solos, em agrupamento com o manejo e uso do solo da microbacia. 
Tabela 39. Número da CN adotado para as condições da MBHRB.

\begin{tabular}{|l|c|c|c|c|c|c|c|}
\hline US0 DO SOL0 & $\begin{array}{c}\text { Neossolo } \\
\text { Quartzarấnico }\end{array}$ & $\begin{array}{c}\text { Latossolo } \\
\text { Amarelo }\end{array}$ & $\begin{array}{c}\text { Latossdo } \\
\text { Vermelho }\end{array}$ & $\begin{array}{c}\text { Latossdo } \\
\text { Roxo }\end{array}$ & Gleissolo & $\begin{array}{c}\text { Árgssdo } \\
\text { Neossdo } \\
\text { Litálico }\end{array}$ \\
\hline Pasto & 79 & 68 & 68 & 68 & 89 & 86 & 89 \\
\hline Agric. Genérica & 70 & 63 & 63 & 63 & 80 & 77 & 80 \\
\hline Laranja & 65 & 43 & 43 & 43 & 82 & 76 & 82 \\
\hline Cana-de-acúcar & 71 & 61 & 61 & 61 & 81 & 78 & 81 \\
\hline Malata & 40 & 20 & 20 & 20 & 52 & 49 & 52 \\
\hline Re1orestamento & 55 & 35 & 35 & 35 & 77 & 70 & 77 \\
\hline Cerrado & 40 & 20 & 20 & 20 & 52 & 49 & 52 \\
\hline
\end{tabular}

O modelo respondeu com grande sensibilidade à variação deste parâmetro, demonstrando ser esta variável de grande impacto na determinação da erosão na microbacia.

O efeito da alteração da CN justifica-se, pois com o aumento do CN, aumenta o escoamento superficial, mas diminui a quantidade de água armazenada no solo que, por conseguinte, poderá vir a alterar o escoamento de base e a evapotranspiração.

Logo, conforme os resultados demonstraram, esperaram-se valores de erosão diferentes, para cada sub-bacia, em relação à cobertura vegetal e tipos de solos, para cada valor de CN.

\subsubsection{Produção de sedimentos}

As simulações iniciais foram para erosão anual, em toneladas por hectare por ano na microbacia, para cada ano do período de 1993 a 2004.

As médias dos valores simulados para erosão das 40 sub-bacias, em toneladas por hectare por ano, para o período de 1993 a 2004, apresentam-se na Tabela 40 e representadas pelas Figuras 38 e 39. 
Tabela 40. Erosão média (ton/ha/ano) simulada para as 41 sub-bacias da MBHRB, no período de 1993 a 2004.

\begin{tabular}{|c|c|c|c|c|c|}
\hline Sub-bacia & ton/ha/ano & Sub-bacia & ton/ha/ano & Sub-bacia & ton/ha/ano \\
\hline 1 & 10,171 & 16 & 14,852 & 31 & 16,264 \\
\hline 2 & 7,065 & 17 & 10,650 & 32 & $0,67 \mathrm{c}$ \\
\hline 3 & 5,007 & 18 & 18,609 & 33 & 7,370 \\
\hline 4 & 8,251 & 19 & 7,112 & 34 & 23,300 \\
\hline 5 & 22,027 & 20 & 27,291 & 35 & 36,175 \\
\hline 6 & 37,684 & 21 & 84,940 & 36 & 3,081 \\
\hline 7 & 9,403 & 22 & 9,466 & 37 & 2,952 \\
\hline 8 & 3,679 & 23 & 26,638 & 38 & 7,716 \\
\hline 9 & 17,327 & 24 & 11,120 & 39 & 6,772 \\
\hline 10 & 104,085 & 25 & 5,697 & 40 & 14,494 \\
\hline 11 & 15,428 & 26 & 28,690 & 41 & 13,693 \\
\hline 12 & 2,604 & 27 & 20,447 & & \\
\hline 13 & 9,711 & 28 & 3,295 & & \\
\hline 14 & 14,270 & 29 & 38,474 & & \\
\hline 15 & 13,738 & 30 & 8,605 & & \\
\hline
\end{tabular}

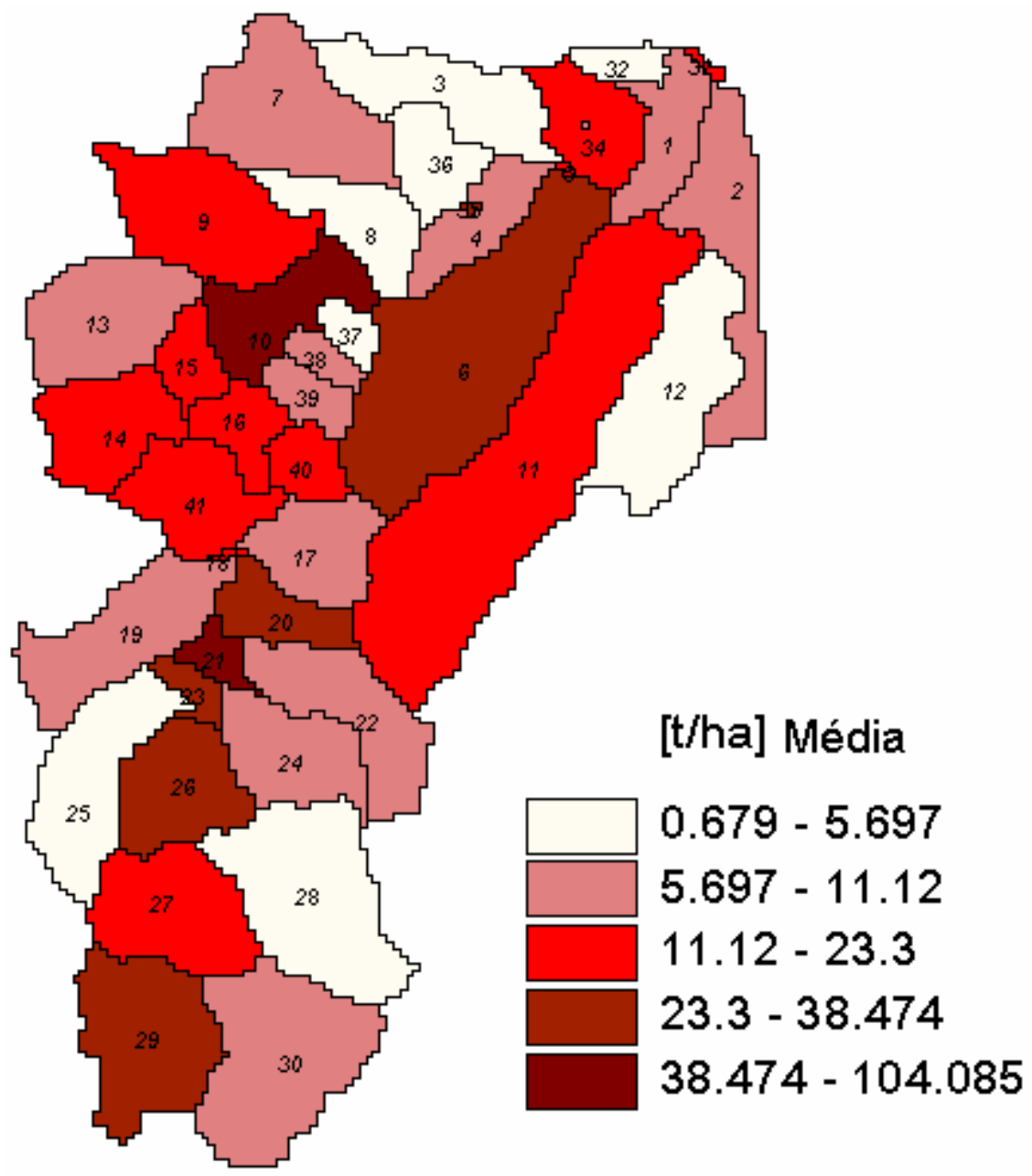

Figura 38. Mapa de erosão média (ton/ha/ano) simulada para as 41 sub-bacias da MBHRB, no período de 1993 a 2004. 


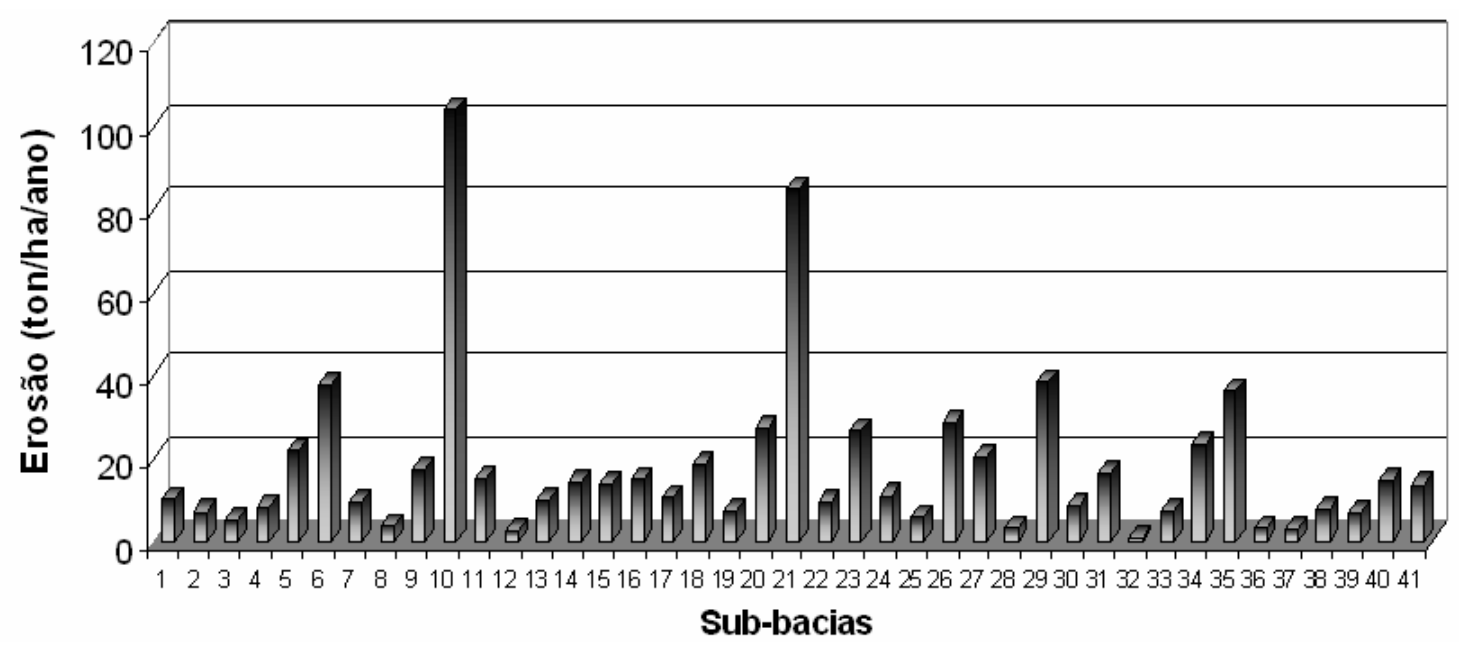

Figura 39. Erosão média (ton/ha/ano) simulada para as 41 sub-bacias da MBHRB, no período de 1993 a 2004.

No período dos 12 anos de simulação, as 10 sub-bacias com maior volume de sedimentos gerados foram, em ordem decrescente: 10, 21, 29, 06 , $35,26,20,23,34$ e 05 , com uma média de 42,93 toneladas de sedimentos gerados por ano.

$\mathrm{Na}$ análise dos fatores que contribuíram para os resultados de erosão em cada sub-bacia, buscou-se evidenciar os fatores isolados para cada tipo de solo e o uso dos solos que foram mais suscetíveis à erosão, analisando-se também a correlação entre eles, neste mesmo sentido.

Desta forma, para todos os tipos de solos da microbacia, foi calculado a média da perda de solos, para o período de 1993 a 2004, a qual pode ser evidenciada pela Tabela 41.

Os resultados não discretizam o uso do solo (cobertura do solo), devendo ser interpretados à luz da quantidade de sedimentos gerados em determinado tipo de solo, não se considerando a cobertura. 
Tabela 41. Média da perda de solo (ton.) simulada para cada tipo de solo da MBHRB para o período de 1993 a 2004.

\begin{tabular}{|l|c|}
\hline \multicolumn{1}{|c|}{ Tipo de Solo } & Média da perda de solo (ton/ha/ano) simulada \\
\hline Neossolo Litólico & 101 \\
\hline Gleissolo & 77 \\
\hline Argissolo & 38 \\
\hline Neossolo Quartzarênico & 15 \\
\hline Latossolo Amarelo & 9 \\
\hline Latossolo vermelho Mesoférrico & 7 \\
\hline Latossolo vermelho Eutroférrico & 4 \\
\hline
\end{tabular}

Da análise dos resultados tabulados, as maiores taxas de erosão, na microbacia em estudo, ocorreram para os seguintes solos, em ordem decrescente de grandeza: Neossolo Litólico, Gleissolo, Argisolo, Neossolo Quartzarênico, Latossolos amarelo, vermelho mesoférrico e vermelho eutroférrico.

Embora alguns resultados de erosão média simulados pelo modelo AVSWAT estejam acima do índice de tolerância de perda de solos estabelecidos por Bertoni e Lombardi Neto (1992) (Tabela 42), os resultados justificam-se pelo manejo e práticas inadequadas na microbacia.

No entanto, como aplicação pioneira na MBHRB, os resultados merecem ser avaliados qualitativamente, sendo relevante à análise criteriosa dos resultados quantitativos. 
Tabela 42. Tolerância de perdas por erosão para alguns solos do Estado de São Paulo. Fonte: Bertoni e Lombardi Neto (1992).

\begin{tabular}{cc}
\hline Unidade de Solo & Tolerância de perda de solo \\
Média ponderada em relação à \\
profundidade (t/ha)
\end{tabular}

COM B TEXTURAL

$\begin{array}{lr}\text { Podzólico v.-a., orto } & 6,6 \\ \text { Podzólico v.-a., v. Piracicaba } & 7,9 \\ \text { Podzólico v.-a., v. Laras } & 9,1 \\ \text { Podzólico em cascalho } & 5,7 \\ \text { Podzólico Lins Marilia, v. Lins } & 4,5 \\ \text { Podzólico Lins Marília, v. Marília } & 6,0 \\ \text { Mediterrâneo vermelho-amarelo } & 12,1 \\ \text { Terra roxa estruturada } & 13,4\end{array}$

COM B TEXTURAL

$\begin{array}{lc}\text { Latossolo roxo } & 12,0 \\ \text { Latossolo vermelho-escuro, orto } & 12,3 \\ \text { Latossolo vermelho-escuro, f. arenosa } & 15,0 \\ \text { Latossolo vermelho-amarelo, orto } & 12,6 \\ \text { Latossolo vermelho-amarelo, f. rasa } & 9,8 \\ \text { Latossolo vermelho-amarelo, f. arenosa } & 14,2 \\ \text { Latossolo vermelho-amarelo, f. terraço } & 12,6 \\ \text { Latossolo vermelho-amarelo, húmico } & 11,2 \\ \text { Solos Campos do Jordão } & 9,6\end{array}$

SOLOS POUCO DESENVOLVIDOS

Litossolo $\quad 4,2$

Regossolo 14,0

Para o conhecimento do volume de sedimentos gerados em cada tipo de cobertura da microbacia, evidenciaram-se, na Tabela 43, as médias de erosão (ton/ha/ano) para o período dos 12 anos de simulação.

Os resultados demonstraram que as práticas de Agricultura Genérica e Pastagens, seguidas de Cana-de-açucar, foram as culturas onde houve maior ocorrência de geração de sedimentos, em volume (ton/ha/ano), não considerando, nestes resultados, os tipos de solos correspondentes. 
Tabela 43. Média da perda de solo (ton/ha/ano) simulada para cada uso do solo da MBHRB para o período de 1993 a 2004.

\begin{tabular}{|l|c|}
\hline \multicolumn{1}{|c|}{ Uso do solo } & Média da perda de solo (ton/ha/ano) simulada \\
\hline Agricultura Genérica & 79,1 \\
\hline Pastagem & 65,6 \\
\hline Área urbana & 21,9 \\
\hline Cana-de-açúcar & 6,6 \\
\hline Mata & 4 \\
\hline Cerrado & 3 \\
\hline Laranja & 2,9 \\
\hline Reflorestamento & 1,9 \\
\hline
\end{tabular}

Desprezaram-se os resultados para Área Urbana, uma vez que não correspondem a áreas agricultáveis.

Como o modelo subdividiu a microbacia em sub-bacias e estas em HRUs, relevante se tornou a correlação entre os tipos de solos, cujas simulações revelaram maior ocorrência de erosão, com os usos do solo, neste mesmo sentido.

A correlação entre tipos e usos de solos evidenciou que determinadas combinações promoveram maiores volumes de erosão (ton/ha/ano).

Estas combinações, maiores geradoras de sedimentos, referem-se exatamente aos tipos de solos, cujos resultados das simulações de erosão foram maiores, combinados com os usos do solo cujos resultados atingiram os maiores volumes de erosão.

Têm-se, neste sentido, um panorama das áreas mais frágeis, nas quais a erosão ocorre em maior escala (Tabela 44). 
Tabela 44. Correlações entre tipos e uso dos solos, valores simulados para erosão e as ocorrências nas sub-bacias da MBHRB.

\begin{tabular}{|c|c|c|c|c|}
\hline ndexador & USO DO SOLO & TIPO DE SOLO & $\begin{array}{c}\text { MÉDIA DE EROSÃO } \\
\text { (ton/ha/ano) }\end{array}$ & $\begin{array}{c}\text { Área na microbacia } \\
\text { (\%) }\end{array}$ \\
\hline A & Pastagem & Neossolo Litólico & 344,94 & 0,489 \\
\hline B & Agric. Genérica & Neossolo Litólico & 280,11 & 0,090 \\
\hline C & Agric. Genérica & Gleissolo & 260,22 & 0,330 \\
\hline D & Pastagem & Gleissolo & 220,70 & 0,594 \\
\hline E & Agric. Genérica & Argissolo & 138,89 & 0,073 \\
\hline F & Pastagem & Argissolo & 134,27 & 1,178 \\
\hline G & Agric. Genérica & Neossolo Quartzarênico & 62,65 & 2,231 \\
\hline H & Pastagem & Neossolo Quartzarênico & 24,59 & 4,370 \\
\hline I & Cana-de-açúcar & Neossolo Litólico & 21,85 & 0,339 \\
\hline J & Cana-de-açucar & Gleissolo & 18,03 & 0,212 \\
\hline K & Cana-de-açucar & Argissolo & 11,31 & 0,708 \\
\hline L & Cana-de-açucar & Neossolo Quartzarênico & 5,17 & 5,709 \\
\hline
\end{tabular}

\begin{tabular}{|c|c|}
\hline Indexador & Sub-bacias de ocorrência \\
\hline A & $10,11,13,26,27,29,30$ \\
\hline B & 10,26 \\
\hline C & $11,19,20,21,22,23,24$ \\
\hline D & $1,2,3,4,5,6,10,11,31,34,41$ \\
\hline E & $1,6,11,34$ \\
\hline F & $1,2,6,11,34$ \\
\hline G & $7,9,10,11,13,15,16,17,18,19,20,21,22,23,24,25,26,28,40,41$ \\
\hline H & $7,, 8,9,10,11,13,15,16,17,19,20,22,24,26,28,40,41$ \\
\hline I & $11,13,14,25,26,29,30$ \\
\hline J & $2,3,4,6,10,11,20,34$ \\
\hline K & $1,2,4,6,11,31,32,34,36$ \\
\hline L & $3,7,8,9,10,11,13,14,15,16,17,19,20,22,23,24,25,26,28,40,41$ \\
\hline
\end{tabular}

As áreas com elevada criticidade à erosão, são áreas com diminuto percentual de participação na área total da microbacia. $O$ volume de sedimentos gerados, resultado das simulações, foi influenciado pela escolha da CN, determinada por Lombardi Neto (1993). Utilizando-se CN norte-americana (SCS-USDA), os valores de erosão simulados seriam menores, pois há razoável discrepância entre os números. 


\subsubsection{Produção de sedimentos nas sub-bacias que contêm granjas}

Nas sub-bacias que contêm granjas, a determinação da produção de sedimentos foi importante, uma vez que os dejetos animais e outros solutos, lançados no solo como fertilizantes, atingem os mananciais, carreados pelos sedimentos gerados, por escorrimento superficial.

Os resultados simulados para erosão média em toneladas por hectare por ano, para o período dos 12 anos de simulação, destacaram a sub-bacia 10, seguida das sub-bacias 20, 24, 22, 30, 4, 39 e 28 como maiores geradoras de sedimentos (Tabelas 45 e Apêndice III; Figura 40).

Tabela 45. Resultados da simulação de erosão para as sub-bacias que contêm granjas, na MBHRB.

\begin{tabular}{|c|c|}
\hline Sub-bacia & Erosão média (ton/ha/ano) \\
\hline 10 & 104,08 \\
\hline 20 & 27,29 \\
\hline 24 & 11,12 \\
\hline 22 & 9,46 \\
\hline 30 & 8,6 \\
\hline 4 & 8,251 \\
\hline 39 & 6,77 \\
\hline 28 & 3,29 \\
\hline
\end{tabular}

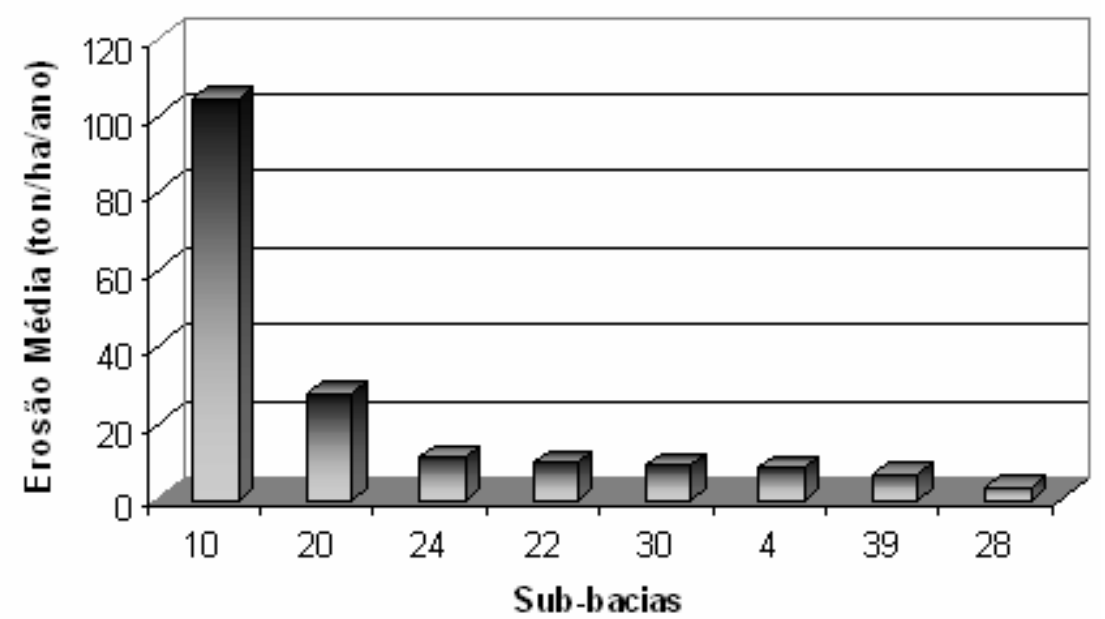

20. Geração de sedimentos nas sub-bacias que contêm granjas na MBHRB. 


\subsubsection{Volume de nitrogênio $(\mathrm{N})$ e fósforo $(\mathrm{P})$ aportado aos mananciais}

Os eventos físicos do escorrimento superficial e sub-superficial transportam solutos para as cotas inferiores do terreno.

De interesse da pesquisa, o aporte de nitrogênio $(N)$ e fósforo $(P)$ foi simulado, em decorrência dos fenômenos hidrossedimentológicos, notadamente o escorrimento superficial.

O aporte de nutrientes para os mananciais ocorreu em função dos sedimentos gerados por erosão na MBHRB, uma vez que estes nutrientes encontravam-se adsorvidos ao sedimento ou livres no solo, sendo ambos carreados pelo escorrimento superficial.

Para o propósito da simulação, parametrizou-se analisar somente os resultados obtidos para os nutrientes nitrogênio $(N)$ e fósforo $(P)$ na fase orgânica, uma vez que estes foram providos pelos dejetos animais "in natura".

Portanto, nos resultados apresentados para os nutrientes, em volume, não estão consideradas as formas mineralizadas resultantes dos processos bioquímicos que sofre a matéria orgânica.

Para análise do efeito da fertilização do solo com dejetos animais, foram simulados os aportes de nutrientes para os mananciais em duas fases: na primeira fase, simulou-se o aporte de nutrientes sem que houvesse sido feita entrada dos dados de dejetos, uma vez que o modelo considera, na composição de cada tipo de solo, seus nutrientes característicos e próprios; na segunda fase, simulou-se o aporte de nutrientes para o canal, considerando a fertilização do solo com dejetos animais.

Neste sentido, a Tabelas 46 e 47 evidenciam os resultados médios, em kilograma de nitrogênio $(N)$ e fósforo $(P)$, aportados aos mananciais da microbacia, para o período dos 12 anos de simulações. 
Tabela 46. Resultados médios, em kilograma, de nitrogênio $(N)$ aportado aos mananciais da MBHRB, para o período dos 12 anos de simulações.

\begin{tabular}{|c|r|r|r|}
\hline & $\begin{array}{c}\text { Quantidade de nitrogênio } \\
\text { (N) natural na sub-bacia } \\
\text { (Kg/ano) }\end{array}$ & $\begin{array}{c}\text { Quantidade de nitrogênio } \\
\text { (N) simulado considerando } \\
\text { aporte das granjas } \\
\text { (Kg/ano) }^{* *}\end{array}$ & Incremento (N) Kg/ano \\
\hline 4 & 107800 & 158063,66 & $50.263,66$ \\
\hline 20 & 50610 & 100005,23 & $49.395,23$ \\
\hline 10 & 85430 & 131659,57 & $46.229,57$ \\
\hline 30 & 4875 & 31922,05 & $27.047,05$ \\
\hline 28 & 3028 & 6531,42 & $3.503,42$ \\
\hline 22 & 5210 & 7122,17 & $1.912,17$ \\
\hline 39 & 734,6 & 2162,42 & $1.427,82$ \\
\hline 24 & 4049 & 4569,91 & 520,91 \\
\hline
\end{tabular}

Tabela 47. Resultados médios, em kilograma, de fósforo $(P)$ aportado aos mananciais da MBHRB, para o período dos 12 anos de simulações.

\begin{tabular}{|c|r|r|r|}
\hline & $\begin{array}{c}\text { Quantidade de fósforo (P) } \\
\text { natural na sub-bacia } \\
\text { (Kg/ano) }\end{array}$ & $\begin{array}{c}\text { Quantidade de fósforo (P) } \\
\text { simulado considerando } \\
\text { aporte das granjas } \\
(\text { Kg/ano) }\end{array}$ & Incremento (P) Kg/ano \\
\hline 4 & 17900 & 41580,06 & 23680,06 \\
\hline 20 & 8318 & 31716,12 & 23398,12 \\
\hline 10 & 14200 & 36726,55 & 22526,55 \\
\hline 30 & 853 & 14019,93 & 13166,93 \\
\hline 28 & 508 & 1652,69 & 1144,69 \\
\hline 22 & 8434 & 1900,52 & 1057,12 \\
\hline 24 & 6593 & 1165,59 & 506,29 \\
\hline 39 & 734,6 & 478,85 & 331,75 \\
\hline
\end{tabular}

* Nitrogênio $(\mathrm{N})$ / Fósforo $(\mathrm{P})$ no solo $(\mathrm{Kg})$ : valores simulados considerando o carreamento dos nutrientes presente naturalmente no solo, que chegam aos mananciais por escorrimento superficial. Não está considerada a fertilização com dejetos animais.

** Nitrogênio $(\mathrm{N})$ / Fósforo $(\mathrm{P})$ total $(\mathrm{Kg})$ : valores simulados considerando o somatório dos nutrientes presentes naturalmente no solo com os nutrientes provenientes da fertilização por dejetos animais.

Os resultados das simulações demonstraram que o aporte de nitrogênio (N) e fósforo $(\mathrm{P})$, provenientes dos dejetos animais, alcançou valores importantes em algumas sub-bacias que contêm granjas (Figuras 41 e 42). 


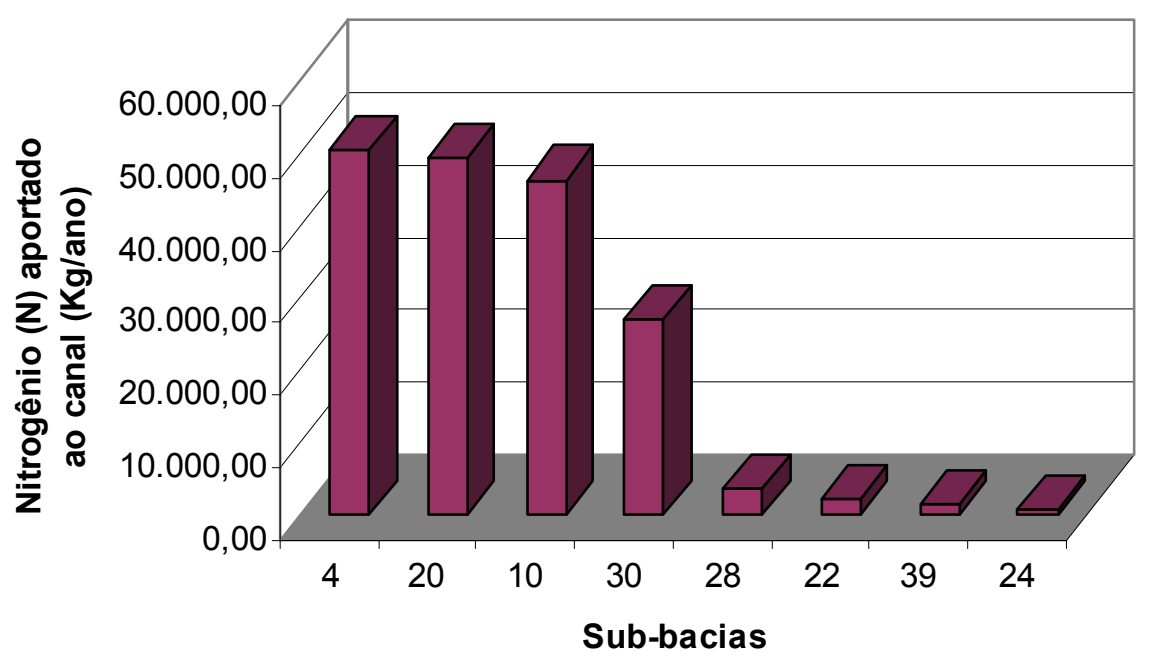

Figura 41. Aporte de nitrogênio ( $N$ ) para o canal da sub-bacia correspondente em kilogramas por ano.

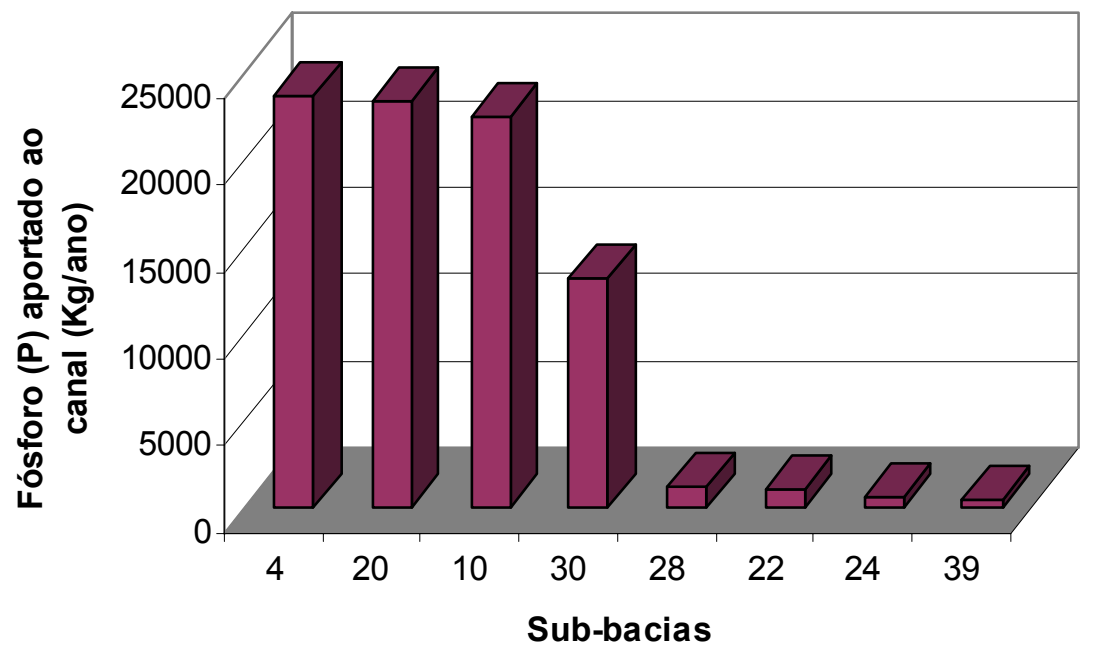

Figura 42. Aporte de fósforo $(P)$ para o canal da sub-bacia correspondente em kilogramas por ano.

Da mesma maneira que o nitrogênio $(N)$, o fósforo $(P)$ orgânico foi transportado pelo escorrimento superficial para o canal principal.

No entanto, a relação entre a carga de nutrientes no canal e o volume de erosão gerado em cada sub-bacia não foi proporcional, indicando que houve retenção e acúmulo de sedimentos em algumas sub-bacias.

Um dos fatores, de elevada relevância, responsável pela retenção dos sedimentos gerados nas sub-bacias é a cobertura vegetal. 
Na microbacia em estudo, Torezan (2000) apud Moraes (2003), ao analisar as áreas ocupadas pelos remanescentes da vegetação, verificou que elas distribuem-se de forma fragmentada, ocupando áreas de declividade acentuada e circundando corpos d'água.

Pode-se inferir que o escorrimento superficial perdeu velocidade ao atingir áreas constituídas pela vegetação adensada, característica das matas, cerrados e reflorestamentos que compõem as áreas de preservação permanente da microbacia. Os sedimentos e os nutrientes carreados podem ter permanecido na sub-bacia, retidos pela vegetação.

O papel das matas ciliares ainda é muito discutido na literatura. Ao mesmo tempo em que funcionam como zona tampão, diminuindo ou impedindo o aporte de sedimentos e solutos para os corpos d'água, podem também atuar como reservatórios de poluentes, disponibilizando grande carga aos mananciais quando saturadas.

Oliveira (1998), em experimentos de avaliação de várias faixas de largura de vegetação natural ou recomposta ao longo de corpos d'água, concluiu que compõem-se de controladoras das fontes dispersas de poluição, uma vez que retêm solutos, impedindo sua propagação pelo terreno.

Neste sentido, os resultados do aporte de nutrientes para os mananciais da MBHRB demonstraram-se coerentes. A entrada de nitrogênio ( $N$ ) e fósforo (P) nos corpo d'água foi inversamente proporcional à distribuição de vegetação caracterizada como cerrado, mata e reflorestamento nas sub-bacias que contêm granjas.

As Figuras 43 e 44 correlacionam os percentuais de vegetação presentes na microbacia com os volumes de nitrogênio $(N)$ e fósforo $(P)$ aportados para o canal correspondente à sub-bacia. 


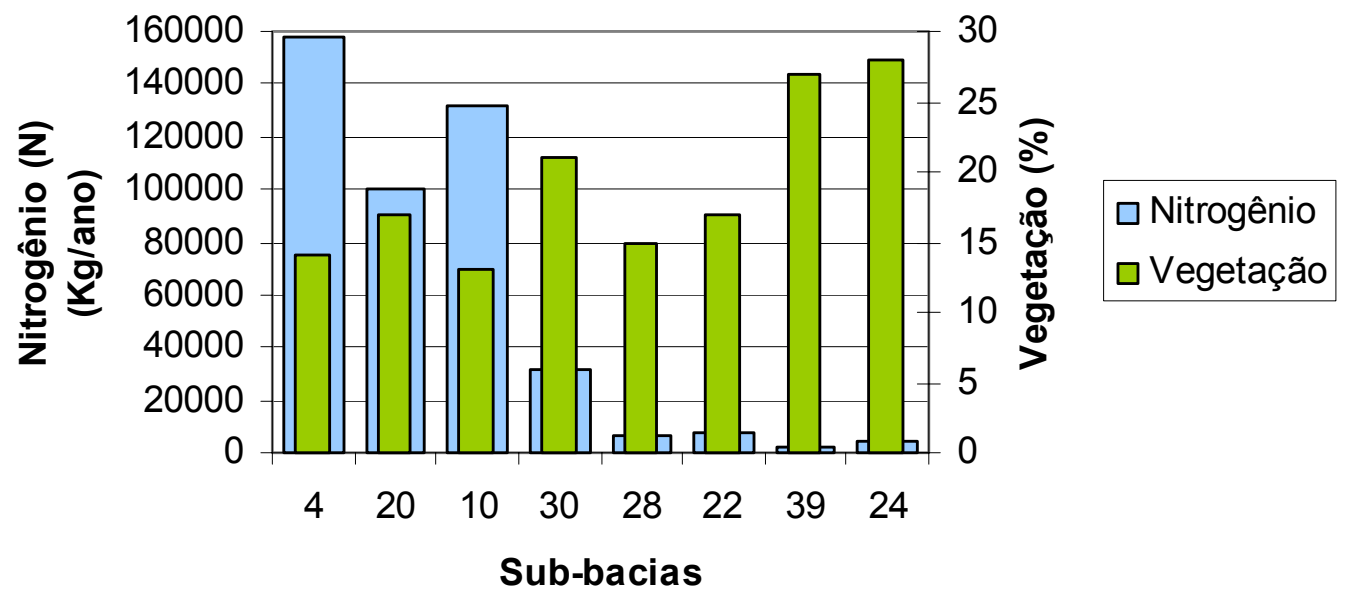

Figura 43. Correlação entre o aporte de nitrogênio $(N)$ para o canal e a presença de vegetação na sub-bacia.

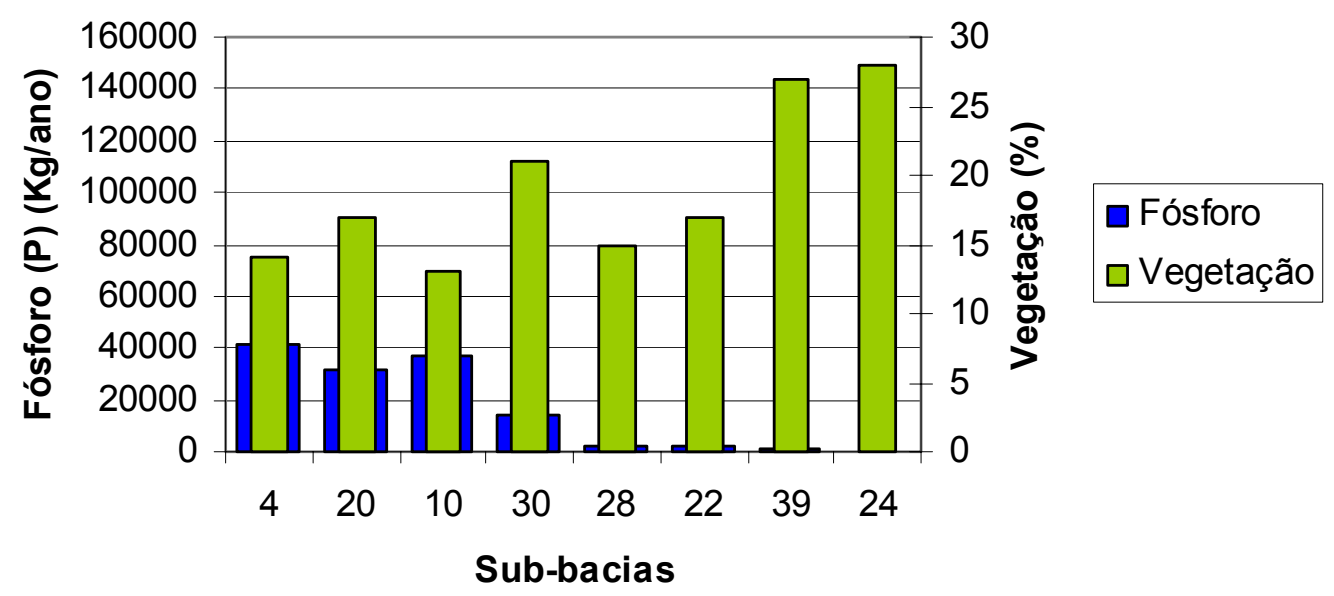

Figura 44. Correlação entre o aporte de fósforo $(P)$ para o canal e a presença de vegetação na sub-bacia. 
Observou-se, no entanto, que, para a sub-bacia 30, a vegetação demonstrou-se não ter eficiência no controle do aporte dos nutrientes ao canal da sub-bacia. Esse fato se explica pela presença nesta sub-bacia da única granja de suínos da MBHRB, o que afetou consideravelmente na concentração de nitrogênio $(N)$ e fósforo $(P)$ considerados nos dejetos totais animais.

Analisando os resultados das simulações do aporte de nutrientes para os mananciais da microbacia, merecem especial atenção as sub-bacias 4, 20, 10 e 30, uma vez que se constituem em importantes fornecedores de nitrogênio $(\mathrm{N})$ e fósforo $(\mathrm{P})$.

Nestas áreas, devem-se avaliar criteriosamente as práticas de fertilização das culturas, principalmente as predominantes pastagem e canade-açúcar, uma vez que outros solutos e poluentes podem atingir os mananciais da microbacia.

\subsubsection{Produção Bibliográfica}

No decorrer do trabalho de pesquisa, com a fruição de resultados, foram submetidos trabalhos para congressos e eventos para discussão com pesquisadores de outros núcleos de pesquisa, na intenção de expor a tecnologia da modelagem hidrossedimentológica AVSWAT em bacias hidrográficas rurais, absorvendo críticas e sugestões para o alcance dos melhores resultados na Dissertação.

Paralelamente, buscou-se aumentar a exposição e divulgação do grupo de pesquisa do Dr. Silvio Crestana, a que o autor é componente, na medida em que os trabalhos foram submetidos e aceitos. 


\subsubsection{Trabalhos completos em anais de eventos}

1. NEVES, Fernando Frachone; SILVA, Fernando das Graças Braga da; MINOTI, Ricardo; CRESTANA, Silvio. Avaliação preliminar da simulação da produção de sedimentos em duas sub-bacias hidrográficas do rio Bonito (Descalvado - SP) utilizando o modelo hidrossedimentológico SWAT. In: 230. CONGRESSO BRASILEIRO DE ENGENHARIA SANITÁRIA E AMBIENTAL, 2005, Campo Grande (MS). 2005.

2. NEVES, Fernando Frachone; SILVA, Fernando das Graças Braga da; CRESTANA, Silvio. Avicultura em áreas suscetíveis à erosão: uma análise do risco à poluição utilizando modelo hidrossedimentológico. In: AGUASUL - 10. SIMPÓSIO DE RECURSOS HÍDRICOS DO SUL - I SIMPÓSIO DE ÁGUAS DA AUGM, 2005, Santa Maria (RS). 2005.

3. NEVES, Fernando Frachone; SILVA, Fernando das Graças Braga da; ANGELOTTI NETTO, Antonio; CRESTANA, Silvio. Simulação da perda de solo em quatro sub-bacias hidrográficas rurais na região de Descalvado SP a partir de modelo hidrossedimentológico. In: X SIMPÓSIO DO CURSO DE CIÊNCIAS DA ENGENHARIA AMBIENTAL - CIÊNCIAS AMBIENTAIS: DIVERSAS ABORDAGENS PARA BACIA HIDROGRÁFICA, 2004, Itirapina (SP). 2004.

4. NEVES, Fernando Frachone; SILVA, Fernando das Graças Braga da; CRESTANA, Silvio. Comparação entre três métodos de evapotranspiração potencial aplicados a duas sub-bacias hidrográficas de Descalvado - SP. In: XVI Simpósio Brasileiro de Recursos Hídricos, 2005, João Pessoa - PB, 2005. 
5. NEVES, Fernando Frachone; SILVA, Fernando das Graças Braga da; CRESTANA, Silvio. Avaliação da perda de solo em sub-bacias hidrográficas da região de Descalvado-SP à partir do modelo AVSWAT. In: XVI Simpósio Brasileiro de Recursos Hídricos, 2005, João Pessoa - PB, 2005.

\subsubsection{Resumos expandidos em anais de eventos}

1. NEVES, Fernando Frachone; CRESTANA, Silvio. A erosão na bacia do rio Bonito (Descalvado - SP) como fator potencializador da poluição por dejeto de granjas. In: IX SIMPÓSIO DO CURSO DE CIÊNCIAS DA ENGENHARIA AMBIENTAL - CIÊNCIAS AMBIENTAIS: DIVERSAS ABORDAGENS PARA BACIA HIDROGRÁFICA, 2003, Itirapina (SP). 2003.

\subsubsection{Capítulo de livro publicado}

1. NEVES, Fernando Frachone; Silva, Fernando das Graças Braga da; CRESTANA, Silvio; LORANDI, Reinaldo. A erosão na bacia do rio Bonito (Descalvado - SP) como fator potencializador da poluição por dejeto de granjas. In: IX SIMPÓSIO DO CURSO DE CIÊNCIAS DA ENGENHARIA AMBIENTAL - CIÊNCIAS AMBIENTAIS: DIVERSAS ABORDAGENS PARA BACIA HIDROGRÁFICA, 2003, Itirapina (SP). 2003.

\subsubsection{Textos em jornais de notícias}

1. NEVES, Fernando Frachone. Poluição difusa em bacias rurais suscetíveis à erosão. SOBRADE - Sociedade Brasileira de Recuperação de Áreas Degradadas, Curitiba (PR), 2004. 


\subsubsection{Palestra}

1. A erosão na Microbacia Hidrográfico do Rio Bonito (Descalvado - SP) como fator potencializador da poluição dos recursos hídricos por dejetos animais. Palestra ministrada ao curso de especialização em Gestão Ambiental do Instituto Brasileiro de Estudos Ambientais e Saneamento (IBEAS), conveniado à UFSCAR - Universidade Federal de São Carlos.

\subsubsection{Trabalhos em finalização}

Para divulgação dos resultados finais da pesquisa, estão sendo preparados trabalhos para Revistas com corpo editorial e elevado conceito e técnica científica. 


\section{CONCLUSÕES E RECOMENDAÇÕES}

\subsection{CONCLUSOES}

Dentre as várias conclusões que se podem afeir do trabalho as principais são apontadas:

- O modelo AVSWAT é um modelo complexo e robusto, de ampla aplicabilidade, sendo sua aplicação encontrada em importantes referencias internacionais atuais. É uma ferramenta importante para a simulação de erosão e transporte de contaminantes em bacias hidrográficas. Sua utilidade é comprovada, servindo de suporte para resultados e fundamentação científica para discussões e propositura de soluções aos problemas ambientais em bacias hidrográficas.

- No Brasil, em revisão bibliográfica realizada, encontraram-se poucas aplicações do AVSWAT em trabalhos científicos. Dos trabalhos encontrados e que se tem conhecimento, utilizaram-se apenas do módulo de erosão. A exceção foi o do relatório PRODOC-CAPES/PPGSEA - EESC/USP. Pela revisão bibliográfica realizada, o presente trabalho é uma aplicação pioneira em termos de Dissertações e Teses no Brasil, com a utilização do módulo de fertilizantes do modelo AVSWAT.

- A quantidade de informações exigidas pelo modelo é de elevada amplitude, constituindo sua qualidade (dados reais e precisos) outro fator determinante para o sucesso da aplicação da modelagem, uma vez que os resultados obtidos podem atingir níveis de correspondência com a realidade da área em estudo. 
- Os problemas no uso de modelos internacionais consistem nas dificuldades de obtenção precisa, entendimento e adaptação dos parâmetros de entrada necessários. No entanto, neste trabalho contouse com alguns diferenciais tais como infra-estrutura da Embrapa Instrumentação Agropecuária e apoio de equipe de pesquisadores interessados no assunto desta instituição e do PPG-SEA-USP e UFSCAR, o que tornou mais rápida a aquisição e interpretação de dados.

- Os primeiros resultados foram obtidos em termos de perda de solo. Apesar de não existirem estudos de campo anteriores, para validação dos resultados, avaliou-se que, para um primeiro estudo nesta microbacia, estes demonstraram-se coerentes, baseados em alguns índices de tolerância de perda de solo da literatura e em função das características de solos, coberturas e declividades das sub-bacias, além de algumas simulações preliminares da Equação de Universal de Perda de Solo (USLE).

- Não se encontraram na literatura informações suficientes de qualidade da água da microbacia, para validação completa do modelo. No entanto os resultados obtidos, relativos ao transporte de nutrientes (Nitrogênio e Fósforo) na microbacia em estudo demonstraram-se coerentes em função de análise dos dados de entrada (áreas de concentração de granja) e posterior resposta do modelo. 


\subsection{RECOMENDAÇÕES}

Este trabalho trata-se de uma aplicação pioneira do modelo AVSWAT na Microbacia Hidrográfica do Rio Bonito (Descalvado-SP), relativa a estudos de erosão e transporte de nutrientes. Portanto estudos posteriores devem ser feitos nos seguintes campos de atuação:

- Obtenção de dados de qualidade da água na bacia para validação completa do modelo;

- Estudos detalhados de calibração de parâmetros diversos do modelo;

- Construção de parcelas experimentais para melhor validação do modelo;

- Aplicação mais complexa da Equação Universal de Perda de Solo na microbacia;

- Em relação às microbacias afetadas por problemas de erosão intensa, sugere-se a adoção da substituição das culturas de pastagem e canade-açúcar por outras culturas, ou até mesmo o reflorestamento com essências nativas regionais, uma vez que há previsão de destinação, no mínimo, de $20 \%$ da área de cada propriedade para vegetação, a título de Reserva Legal.

- Outra recomendação é a recomposição da mata ciliar ou Área de Preservação Permanente, nas áreas degradadas, respeitando-se o que determina o Código Florestal (Lei 4.771/65) quanto a largura mínima da faixa de vegetação no entorno dos cursos d'água.

- Uma importante medida sugerida é a regularização das granjas da microbacia, uma vez que se enquadram como atividades potencialmente poluidoras. As granjas, neste sentido, necessitam de licenciamento, segundo a Resolução CONAMA 237/97, podendo funcionar somente 
após serem aprovados todos projetos mitigadores de eventuais impactos ambientais decorrentes da atividade. 


\section{REFERÊNCIAS BIBLIOGRÁFICAS}

ARNOLD, J. G., SRINIVASAN, R., MUTTIAH, R. S. E WILLIAMS, J. R. (1998). "Large área hydrologic modeling and assessment. Part I: Model development." Journal of the American Water Resources Association, 34 (1), 73 - 89.

BELLI FILHO, P.; COSTA, R. H. R. da; SOARES, S. R.; CASTILHOS JÚNIOR, A. B. (2000). Gestão Ambiental dos Sistemas de Produção de Suínos para o Sul do Brasil. In: FRANKENBERG, C. L. C.; RODRIGUES, M. T. R.; CANTELLI, M. (Orgs.) Gerenciamento de Resíduos e Certificação Ambiental. Porto Alegre: EDIPUCRS, p. 280 - 291.

BERTOLINI, D.; LOMBARDI NETO, F.; DRUGOWICH, M.I. (1993). Programa estadual de microbacias hidrográficas. Campinas: CATI,16 p.

BUSSCHER, W. J.; REEVES, D. W.; KOCHHANN, R. A. et al. (1996). Conservation arming in southern Brazil: using cover crops to decrease erosion and ncrease infiltration. Journal of Soil and Water Conservation, v.51, n.3, .188-192.

CALIJURI, M. L.; MEIRA, A. D.; PRUSK, F. F. (1998). Geoprocessamento Aplicado aos Recursos Hídricos. In: CONGRESSO BRASILEIRO DE ENGENHARIA AGRíCOLA, 27., Poços de Caldas, 1998. Cartografia, Sensoriamento e Geoprocessamento. Lavras: UFLA, SBEA, p.200-225.

CALIJURI, M.C.; OLIVEIRA, H.T. (2000). Manejo da qualidade da água: uma abordagem metodológica. In: CASTELLANO, E.G.; CHAUDHRY, F.H. Desenvolvimento sustentado: problemas e estratégias. São Carlos, EESCUSP. P.39-58. 
COSTA, L.M.; MATOS, A.T. (1997). Impactos da Erosão do solo em recursos hídricos. In: SILVA, D.D.; PRUSKI, F.F. (eds.), Programa de Suporte Técnico à Gestão de Recursos Hídricos. Recursos Hídricos e Desenvolvimento Sustentável da Agricultura. Brasília. p. 173-189.

CRESTANA, S. (2000). Harmonia e Respeito Entre Homens e Natureza: Uma Questão de Vida - A Contribuição da Agricultura. In: CASTELLANO, E.G.; CHAUDHRY, F.H. (eds.), Desenvolvimento Sustentado: Problemas e Estratégias. São Carlos. EESC-USP. Cap.9, p. 169-180.

DEFRA (2002). Agriculture and Water: a diffuse pollution review. Department for Environment, Food and Rural Affairs.

DI LUZIO, M.; SRINIVASAN, R. \& ARNOLD, J. (2001). ArcView Interface for SWAT2000 - User's Guide. Blackland Research Center, Texas Agricultural Experiment Station, Temple, Texas, EUA.

EPA - Environmental Protection Agency (2003) Draft Report on the Environment. Office of Environmental Information and the Office of Research and Development. Washington, DC.

FERES, R. (2002). Análise de processos de erosão acelerada, com base em fotografias aéreas e geoprocessamento: Bacia do Rio Bonito (Descalvado,SP). Tese de Doutorado apresentada ao Centro de Ciências Biológicas e da Saúde, PPG-Ecologia e Recursos Naturais da Universidade Federal de São Carlos. São Carlos (SP).

FILHO, L.C.P.M.; SILVEIRA, M.C.A.C.; HÖTZEL, M.J.; MACHADO, L.C.P. Produção agroecológica de suínos - Uma alternativa sustentável para a pequena propriedade no Brasil. II Conferência Internacional Virtual sobre a Qualidade de Carne Suína.

FINK, D. R.; JR., H. A.; DAWALIBI, M. (2000). Aspectos Jurídicos do Licenciamento Ambiental. $1^{\text {a }}$. Edição. Rio de Janeiro. Editora Forense Universitária. 
FONSECA, H. S. (2002). Qualidade das águas superficiais de uma bacia hidrográfica sujeita a processos erosivos - Estudo de caso do Rio Bonito, em Descalvado, SP. Dissertação de Mestrado apresentada ao Centro de Ciências Exatas e de Tecnologia, Engenharia Urbana da Universidade Federal de São Carlos. São Carlos (SP).

FRASER, D.; MENCH, J. A..; MILLMAN, S. T. (2001). Farm animals and their welfare in 2000. In: Salem, D. J., ROWAN, A. (editors), State of the Animals 2001, Humane Society Press, Washington, DC, USA.

GARRIDO, J. M. (2003). Aplicação de modelo matemático de simulação com utilização de SIG à bacia do Rio Jiquiriçá - Bahia. Dissertação de Mestrado submetida ao Departamento de Engenharia Civil e Ambiental da Faculdade de Tecnologia da Universidade de Brasília. Brasília (DF).

IBGE, 2002. Produção da Pecuária Municipal de 2002. Comunicação Social de 27 de novembro de 2003.

ITO, T. \& KAWAOKA, Y. (2000). Host range barrier of influenza A virus. Vet. Microbiology 74: 71-75.

KIDA, H., ITO, T., YASUDA, J., SHIMIZU, Y, ITAKURA, C., SHORTRIDGE K. F., KAWAOKA, Y. \& WEBSTER, R.C. (1994) Potential for transmisson of avian influenza virus to pigs. J. Gen. Virol. 75: 2183-2188.

LAL R. (1990). Soil erosion and land degradation: the global risks. Advances in Soil Science, v.7, p.129-172.

LOMBARDI NETO et al (1989). Nova abordagem para cálculo de espaçamento entre terraços. Simpósio sobre terraceamento agrícola. Campinas. Fundação Cargill. p. 99-124.

MACHADO, R. E. (2002). Simulação de escoamento e de produção de sedimentos em uma microbacia hidrográfica utilizando técnicas de modelagem e geoprocessamento.Tese apresentada à Escola Superior de Agricultura "Luiz de Queiroz", Universidade de São Paulo. Piracicaba (SP). 
MELOTTI, L.; LUCCI, C.S.; MORGULLIS, S.C.F.; CASTRO, A.L.; RODRIGUES, P.H.M. Degradabilidade ruminal de camas de frangos pela técnica dos sacos de náilon in situ com bovinos. Braz. J. vet. Res. anim. Sci., São Paulo, v. 35, n. 2, p. 92-95, 1998.

MENEZES, J.F.S.; ANDRADE, C.L.T.; ALVARENGA, R.C.; KONZEN, E.; PIMENTA, F.F. Utilização de resíduos orgânicos na agricultura. Palestra apresentada no Agrishow em Ribeirão Preto, SP, em 03.05.2002. Realização: Fundação de Ensino Superior de Rio Verde (GO), Embrapa Milho e Sorgo, Perdigão Agroindustrial S.A.

MOLDAN, B.; CERNY, J. (1994). Small Catchments Research. In MOLDAN, B.; CERNY, J. Biogeochemistry of small catchments: a tool for environmental research. Chicester: John Wiley, p. 1-29.

MORAES, M.E.B. (2003). Zoneamento Ambiental de Bacias Hidrográficas: uma abordagem metodológica aplicada na Bacia do Rio Bonito (SP). Tese de Doutorado apresentada à Universidade Federal de São Carlos. São Carlos (SP).

NEITSCH, S.L.; ARNOLD, J.G.; WILLIAMS, J.R. (2000). Soil and water assessment tool - User's Manual: Version 2000. Temple: Blackland Research Center, Texas Agricultural Experiment Station, 458p.

NEITSCH, S. L., ARNOLD, J. G., KINIRY, J. R. E WILLIAMS, J.R. (2002). Soil and Water Assessment Tool. Theoretical Documentation. Version 2000. Agricultural Research Service / Texas Agricultural Experiment Station, Texas, E.U.A.

NEVES, F. F.; SILVA, F. G. B.; CRESTANA, S. (2005a). Avicultura em áreas suscetíveis à erosão: uma análise do risco à poluição utilizando um modelo hidrossedimentológico. In: AGUASUL - $1^{\circ}$. Simpósio de recursos hídricos do Sul - I Simpósio de águas da AUGM. Santa Maria, RS. 
NEVES, F. F.; SILVA, F. G. B.; CRESTANA, S. (2005b). Comparação entre três métodos de evapotranspiração potencial aplicados a duas sub-bacias hidrográficas de Descalvado - SP. In: XVI Simpósio brasileiro de recursos hídricos. João Pessoa, PB.

OLIVEIRA, P. A. V. (1993). Manual de Manejo e Utilização dos Dejetos de Suínos. Concórdia: EMBRAPA-CNPSA, Documento 27.

OLIVEIRA, H. H. (1994). Área de proteção ambiental de Descalvado - SP. Mapa de hidrografia. Departamento de Ecologia Geral do Instituto de Biociências da USP - IB/USP, NMA/EMBRAPA.

OLIVEIRA, L.M. (1998). Controle de fontes dispersas de poluição pela fixação de largura mínima de faixa de vegetação natural ou recomposta ao longo de corpos d'água. Dissertação de Mestrado apresentada à Escola de Engenharia de São Carlos, da Universidade de São Paulo. São Carlos $(\mathrm{SP})$.

OLIVEIRA, C. R. V. (2001). Sistema Inteligente de apoio à decisão aplicado à área de poluição ambiental causada por dejetos de suínos. Dissertação de Mestrado apresentada ao Departamento de Informática e Estatística da Universidade Federal de Santa Catarina. Florianópolis (SC).

PALHARES, J. C. P. (2004). Cama de aviário: possibilidades de utilização. In: Embrapa Suínos e Aves. Artigo técnico.

PEREIRA, V.P.; FERREIRA, M.E.; CRUZ, M.C.P. (1992). Solos altamente suscetíveis à erosão. IX Reunião Brasileira de Manejo e Conservação do Solo e da Água. Faculdade de Ciências Agrárias e Veterinárias. UNESP. Jaboticabal (SP).

PRETTO, GIOVANNO (2003). Técnica de Análise do Ciclo de Vida para gerenciamento ambiental de propriedades produtoras de suínos. Dissertação de Mestrado apresentada à Universidade Federal de Viçosa, fevereiro de 2003. 
PRUSKI, F.F. (1997). Aplicação de modelos físico-matemáticos para a conservação de água e solo. In: SILVA, D.D.; PRUSKI, F.F. (eds.), Programa de Suporte Técnico à Gestão de Recursos Hídricos. Recursos Hídricos e Desenvolvimento Sustentável da Agricultura. Brasília. p. 129171.

RANIERI, V. E. L. (2000). Discussão das potencialidades e restrições do meio como subsídio para zoneamento ambiental: o caso do município de Descalvado. Dissertação de Mestrado em Ciências da Engenharia Ambiental, apresentada à Escola de Engenharia de São Carlos da Universidade de São Paulo. São Carlos (SP), Brasil.

RENNÓ, C. D.; SOARES, J. V. (2003). Conceitos básicos de modelagem hidrológica. Simpósio Brasileiro de Sensoriamento Remoto. INPE.

ROPPA, L. (1999). Situação atual e tendências da suinocultura mundial. In: Simpósio Brasileiro de Ambiência e Qualidade na Produção Industrial de Suínos. Piracicaba. Anais Piracicaba: NUPEA/ESALQ/USP.

ROPPA, L. (2001). A Globalização e as Perspectivas da Produção de Suínos no Continente Sul-Americano. $9^{\circ}$ Seminário Nacional de Desenvolvimento da Suinocultura; Abril/2001. Gramado (RS).

SARTORI, A. (2004). Avaliação da Classificação Hidrológica do Solo para a Determinação do Excesso de Chuva do Método do Serviço de Conservação do Solo dos Estados Unidos. Dissertação de Mestrado apresentada à Comissão de pós-graduação da Faculdade de Engenharia Civil da Universidade Estadual de Campinas. Campinas (SP), Brasil.

SILVA, A. M.; SCHULZ, H. E.; CAMARGO, P. B. (2003). Erosão e Hidrossedimentologia em Bacias Hidrográficas. São Carlos (SP). Editora Rima. 
SILVA, E. T.; MAGALHÃES, C. S. (2001). Controle de poluição de atividades pecuárias. Informe Agropecuário - Recuperação de áreas degradadas. V. 22, n.210.

SILVA, F. G. B.; CRESTANA, S. (2004). Modelos e formulações para análise de erosão de solos em bacias hidrográficas voltados ao planejamento ambiental: revisão e aplicações preliminares. Vol 3 da Série Ciências da Engenharia Ambiental, Rima.

SILVA, F. G. B. (2004). Relatório Científico bianual relativo ao programa PRODOC-CAPES/PPG-SEA - EESC/USP. Erosão do solo e qualidade da água. O conceito de tolerância de perda de solo com uma nova abordagem voltada ao planejamento ambietal.

SOUTO, A. R., CRESTANA, S. (2000). Identificação das áreas potenciais de produção de sedimentos com o modelo AGNPS e técnicas de SIG em uma microbacia hidrográfica. Revista Brasileira de Engenharia Agrícola e Ambiental, v.4, n.3, p.429-435.

SOUTO, A. R. (1998). Análise Espacial e Temporal da Produção de Sedimentos em uma Microbacia Rural com o Modelo AGNPS e Técnicas de SIG. Dissertação de Mestrado apresentada à Escola de Engenharia de São Carlos, da Universidade de São Paulo. São Carlos (SP).

TAKITANE, I. C.; SOUZA, M. C. M. (2000). Produção de suínos no Brasil: impactos ambientais e sustentabilidade. Anais do XXXVIII Congresso Brasileiro de Economia e Sociologia Rural. X Congresso Mundial de Sociologia Rural. Rio de Janeiro (RJ), Brasil.

TOREZAN, F. E. (2000). Análise ambiental da bacia do rio Bonito (Descalvado, SP) com ênfase nas atividades de exploração mineral de areia. Dissertação de Mestrado apresentada à Universidade Federal de São Carlos. São Carlos (SP). 
TRIBE, A.(1992) Automated recognition of valley lines and drainage networks from digital elevation models: a review and a new method. Journal of Hydrology, v.139, p.263-293.

TUCCI, E. M. 1997a. Hidrologia Ciência e Aplicação. In: TUCCI, E. M. Hidrologia Ciência e Aplicação. 2 ed. Porto Alegre: Editora da Universidade: ABRH. p.25-31.

WISCHMEIER, W. H.; SMITH, D.D. (1978). Predicting rainfall erosion losses a guide to conservation planning. Washington: USDA. 58p. (USDA: Agricultural Handbook, 537).

ZILLI, J,B.; BORDON, G.V.; ZEN, S.D. Situação das agroindústrias avícolas brasileiras: uma comparação entre as plantas industriais do Sul e do Centro-Oeste do Brasil. XL Congresso Brasileiro de Economia e Sociologia Rural. 
APÊNDICE I 


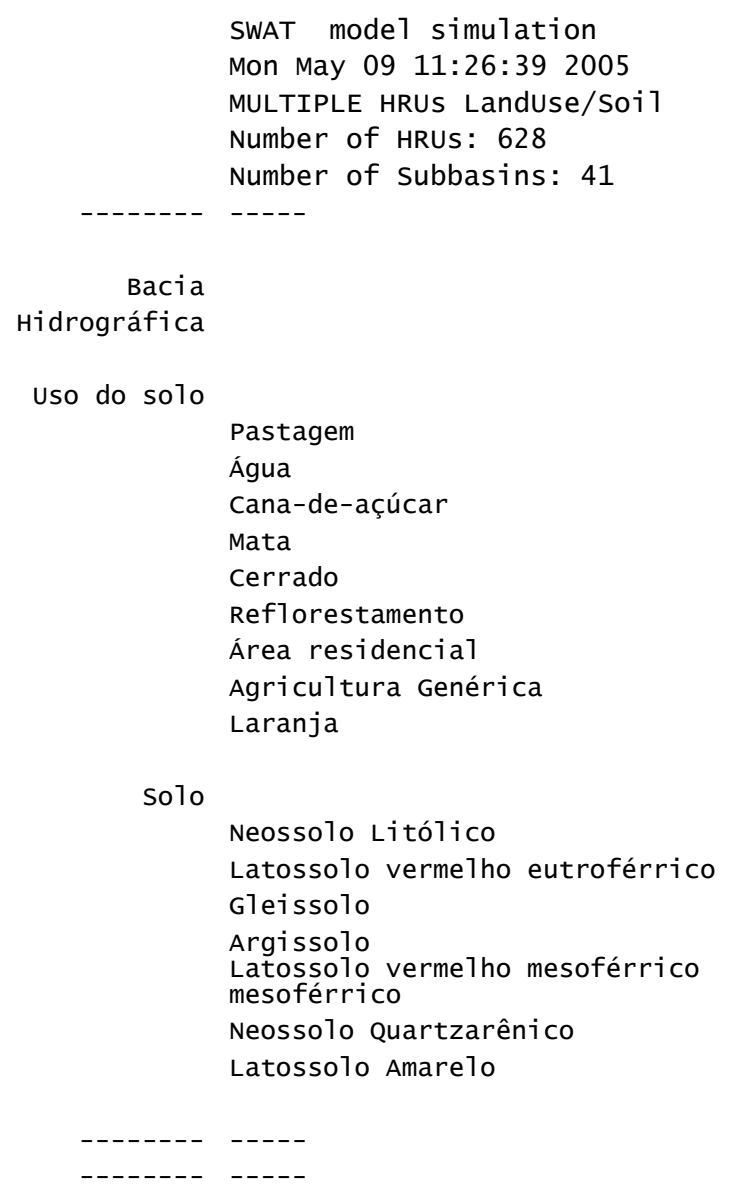

Sub-bacia 1

Uso do solo

Pastagem

Cana-de-açúcar

Mata

Cerrado

Agricu1tura Genérica

Laranja

Solo

Gleissolo

Latossolo Amarelo

Argissolo

HRUS :

1 Pastagem/Argissolo

2 Pastagem/Gleissolo

3 Pastagem/Latossolo Amarelo

4 Cana-de-açúcar/Argissolo

5 Cana-de-açúcar/Latossolo Amarelo

6 Mata/Gleissolo

7 Mata/Latossolo Amarelo

8 Cerrado/Argissolo

9 Cerrado/Gleissolo

10 Cerrado/Latossolo Amarelo

11 Agricultura Genérica/Argissolo

12 Agricultura Genérica/Latossolo Amarelo

13 Laranja/Argissolo
Area [ha] \%Microb.

228.759 .864

$43.622 .671 \quad 19.07$

$114.230 \quad 0.05$

$58.063 .081 \quad 25.38$

$19.454 .150 \quad 8.50$

$28.855 .583 \quad 12.61$

$3.233 .170 \quad 1.41$

$11.424 .285 \quad 4.99$

$15.369 .550 \quad 6.72$

$48.623 .143 \quad 21.26$

$6.767 .128 \quad 2.96$

$30.600 .475 \quad 13.38$

$6.157 .238 \quad 2.69$

$10.756 .529 \quad 4.70$

$18.279 .717 \quad 7.99$

$51.581 .875 \quad 22.55$

$104.616 .902 \quad 45.73$

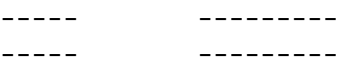

Area [ha] \%Microb. \%Sub-b. N.HRUs

$4.144 .721 \quad 1.81$

$\begin{array}{lll}697.626 & 0.30 & 16.83\end{array}$

$\begin{array}{lll}1.149 .032 & 0.50 & 27.72\end{array}$

$\begin{array}{lll}266.739 & 0.12 & 6.44\end{array}$

$\begin{array}{lll}451.405 & 0.20 & 10.89\end{array}$

$\begin{array}{lll}307.776 & 0.13 & 7.43\end{array}$

$\begin{array}{lll}1.272 .142 & 0.56 & 30.69\end{array}$

$\begin{array}{lll}800.218 & 0.35 & 19.31\end{array}$

$2.544 .284 \quad 1.11 \quad 61.39$

$\begin{array}{lll}800.218 & 0.35 & 19.31\end{array}$

$\begin{array}{rrrr}61.555 & 0.03 & 1.49 & 1 \\ 123.111 & 0.05 & 2.97 & 2 \\ 512.961 & 0.22 & 12.38 & 3 \\ 225.703 & 0.10 & 5.45 & 4 \\ 923.329 & 0.40 & 22.28 & 5 \\ 123.111 & 0.05 & 2.97 & 6 \\ 143.629 & 0.06 & 3.47 & 7 \\ 41.037 & 0.02 & 0.99 & 8 \\ 143.629 & 0.06 & 3.47 & 9 \\ 266.739 & 0.12 & 6.44 & 10 \\ 20.518 & 0.01 & 0.50 & 11 \\ 287.258 & 0.13 & 6.93 & 12 \\ 451.405 & 0.20 & 10.89 & 13\end{array}$




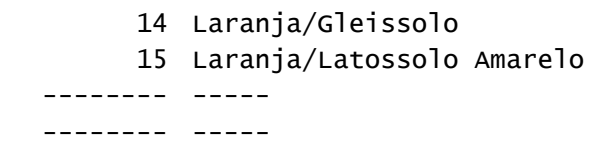

Sub-bacia 2

Uso do solo

Pastagem

Cana-de-açúcar

Mata

Cerrado

Reflorestamento

Área residencial

Agricultura Genérica

Laranja

Solo

Gleissolo

Latossolo Amarelo

Argissolo

HRUS :

16 Pastagem/Argissolo

17 Pastagem/Gleissolo

18 Pastagem/Latossolo Amarelo

19 Cana-de-açúcar/Argissolo

20 Cana-de-açúcar/Gleissolo

21 Cana-de-açúcar/Latossolo Amarelo

22 Mata/Latossolo Amarelo

23 Cerrado/Argissolo

24 Cerrado/G1eissolo

25 Cerrado/Latossolo Amarelo

26 Reflorestamento/Latossolo Amarelo

28 Área Residencial/Gleissolo

29 Área Residencial/Latossolo Amarelo

30 Agricultura Genérica/Latossolo Amarelo

31 Laranja/Argissolo

32 Laranja/Latossolo Amarelo

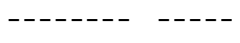

Sub-bacia 3

Uso do solo

Pastagem

Cana-de-açúcar

Mata

Cerrado

Reflorestamento

Agricultura Genérica

Laranja
27 Área Residencial/Argissolo

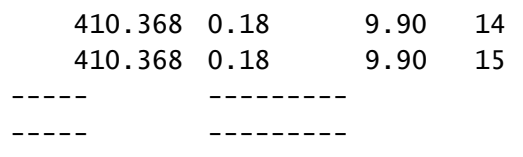

Area [ha] \%Microb. \%Sub-b. N.HRUs

$7.530 .260 \quad 3.29$

$\begin{array}{rrr}1.080 .160 & 0.47 & 14.34 \\ 1.481 .363 & 0.65 & 19.67 \\ 308.617 & 0.13 & 4.10 \\ 894.990 & 0.39 & 11.89 \\ 30.862 & 0.01 & 0.41 \\ 462.926 & 0.20 & 6.15 \\ 586.373 & 0.26 & 7.79 \\ 2.684 .970 & 1.17 & 35.66\end{array}$

$\begin{array}{lll}370.341 & 0.16 & 4.92\end{array}$

$\begin{array}{lll}6.820 .440 & 2.98 & 90.57\end{array}$

$\begin{array}{lll}339.479 & 0.15 & 4.51\end{array}$

$\begin{array}{llll}30.862 & 0.01 & 0.41 & 1\end{array}$

$\begin{array}{llll}61.723 & 0.03 & 0.82 & 2\end{array}$

$\begin{array}{llll}987.575 & 0.43 & 13.11 & 3\end{array}$

$\begin{array}{llll}61.723 & 0.03 & 0.82 & 4\end{array}$

$\begin{array}{llll}92.585 & 0.04 & 1.23 & 5\end{array}$

$\begin{array}{llll}1.327 .054 & 0.58 & 17.62 & 6\end{array}$

$\begin{array}{llll}308.617 & 0.13 & 4.10 & 7\end{array}$

$\begin{array}{llll}61.723 & 0.03 & 0.82 & 8\end{array}$

$\begin{array}{llll}92.585 & 0.04 & 1.23 & 9\end{array}$

$\begin{array}{llll}740.681 & 0.32 & 9.84 & 10\end{array}$

$\begin{array}{llll}30.862 & 0.01 & 0.41 & 11\end{array}$

$\begin{array}{llll}154.309 & 0.07 & 2.05 & 12\end{array}$

$\begin{array}{llll}123.447 & 0.05 & 1.64 & 13\end{array}$

$\begin{array}{llll}185.170 & 0.08 & 2.46 & 14\end{array}$

$\begin{array}{llll}586.373 & 0.26 & 7.79 & 15\end{array}$

$\begin{array}{llll}30.862 & 0.01 & 0.41 & 16\end{array}$

$\begin{array}{llll}2.654 .108 & 1.16 & 35.25 & 17\end{array}$

--------

Area [ha] \%Microb. \%Sub-b. N.HRUs

$6.750 .560 \quad 2.95$

$\begin{array}{rrr}811.776 & 0.35 & 12.03 \\ 2.905 .304 & 1.27 & 43.04 \\ 192.263 & 0.08 & 2.85 \\ 1.046 .764 & 0.46 & 15.51 \\ 42.725 & 0.02 & 0.63 \\ 320.438 & 0.14 & 4.75 \\ 1.431 .290 & 0.63 & 21.20\end{array}$

Solo

Gleissolo

Latossolo Amarelo

Argissolo

Latossolo vermelho eutroférrico

Neossolo Quartzarênico

Latossolo vermelho mesoférrico

mesoférrico

$149.538 \quad 0.07$

2.22

$1.345 .839 \quad 0.59$

19.94

$234.988 \quad 0.10$

3.48

$3.268 .467 \quad 1.43$

48.42

$640.876 \quad 0.28$

9.49

$\begin{array}{lll}1.110 .852 & 0.49 & 16.46\end{array}$

HRUS:

33 Pastagem/Gleissolo

$\begin{array}{llll}21.363 & 0.01 & 0.32 & 1\end{array}$ 


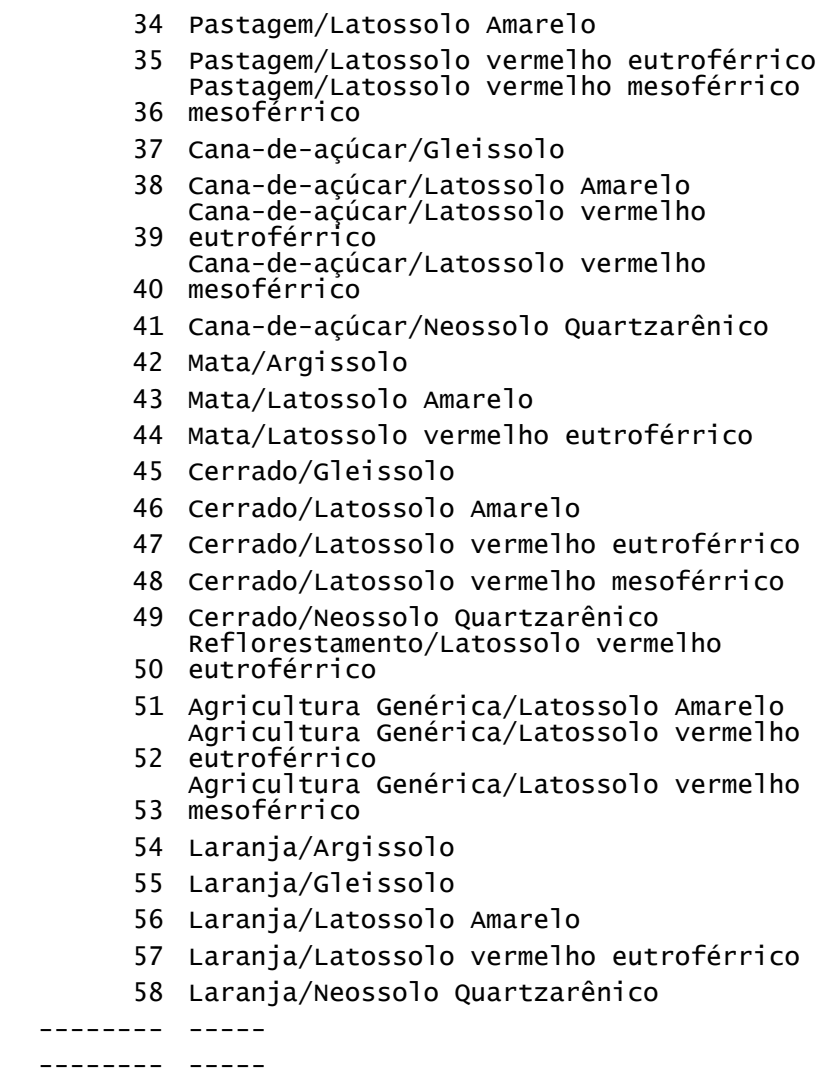

Sub-bacia 4

Uso do solo

Pastagem

Cana-de-açúcar

Mata

Cerrado

Reflorestamento

Área residencial

Agricultura Genérica

Laranja

Solo

Gleissolo

Latossolo Amarelo

Latossolo vermelho eutroférrico

Argissolo

HRUS:

59 Pastagem/G1eissolo

60 Pastagem/Latossolo Amare1o

61 Cana-de-açúcar/Argissolo

62 Cana-de-açúcar/Gleissolo

63 Cana-de-açúcar/Latossolo Amarelo cana-de-açúcar/Latossolo vermelho

64 eutroférrỉco

65 Mata/Latossolo vermelho eutroférrico

66 Cerrado/Gleissolo

67 Cerrado/Latossolo Amare1o

68 Cerrado/Latossolo vermelho eutroférrico

69 Reflorestamento/Latossolo Amarelo

70 Área Residencial/Latossolo Amarelo

71 Agricultura Genérica/Latossolo Amarelo Agricultura Genérica/Latossolo vermelho

72 eutroférrico

73 Laranja/Argissolo

$\begin{array}{rlrr}42.725 & 0.02 & 0.63 & 2 \\ 598.151 & 0.26 & 8.86 & 3 \\ 149.538 & 0.07 & 2.22 & 4 \\ 21.363 & 0.01 & 0.32 & 5 \\ 341.801 & 0.15 & 5.06 & 6 \\ 1.452 .652 & 0.64 & 21.52 & 7 \\ 555.426 & 0.24 & 8.23 & 8 \\ 534.063 & 0.23 & 7.91 & 9 \\ 21.363 & 0.01 & 0.32 & 10 \\ 106.813 & 0.05 & 1.58 & 11 \\ 64.088 & 0.03 & 0.95 & 12 \\ 21.363 & 0.01 & 0.32 & 13 \\ 192.263 & 0.08 & 2.85 & 14 \\ 448.613 & 0.20 & 6.65 & 15 \\ 320.438 & 0.14 & 4.75 & 16 \\ 64.088 & 0.03 & 0.95 & 17 \\ 42.725 & 0.02 & 0.63 & 18 \\ 21.363 & 0.01 & 0.32 & 19 \\ 213.625 & 0.09 & 3.16 & 20 \\ 85.450 & 0.04 & 1.27 & 21 \\ 213.625 & 0.09 & 3.16 & 22 \\ 85.450 & 0.04 & 1.27 & 23 \\ 640.876 & 0.28 & 9.49 & 24 \\ 448.613 & 0.20 & 6.65 & 25 \\ 42.725 & 0.02 & 0.63 & 26 \\ ---- & -------- & \\ ---- & ------- & & \end{array}$

Area [ha] \%Microb. \%Sub-b. N.HRUs

$3.898 .500 \quad 1.70$

$1.251 .624 \quad 0.55$

32.11

$\begin{array}{lll}1.169 .550 & 0.51 & 30.00\end{array}$

$\begin{array}{lll}164.147 & 0.07 & 4.21\end{array}$

$\begin{array}{lll}348.813 & 0.15 & 8.95\end{array}$

$\begin{array}{lll}20.518 & 0.01 & 0.53\end{array}$

$\begin{array}{lll}287.258 & 0.13 & 7.37\end{array}$

$\begin{array}{lll}143.629 & 0.06 & 3.68\end{array}$

$\begin{array}{lll}512.961 & 0.22 \quad 13.16\end{array}$

$\begin{array}{lll}164.147 & 0.07 & 4.21\end{array}$

$2.934 .134 \quad 1.28 \quad 75.26$

$\begin{array}{lll}636.071 & 0.28 & 16.32\end{array}$

$\begin{array}{lll}164.147 & 0.07 & 4.21\end{array}$

$\begin{array}{llll}20.518 & 0.01 & 0.53 & 1\end{array}$

$\begin{array}{rrrr}1.231 .105 & 0.54 & 31.58 & 2\end{array}$

$\begin{array}{llll}102.592 & 0.04 & 2.63 & 3\end{array}$

$\begin{array}{llll}123.111 & 0.05 & 3.16 & 4\end{array}$

$\begin{array}{llll}759.182 & 0.33 & 19.47 & 5\end{array}$

$\begin{array}{llll}184.666 & 0.08 & 4.74 & 6\end{array}$

$\begin{array}{llll}164.147 & 0.07 & 4.21 & 7\end{array}$

$\begin{array}{llll}20.518 & 0.01 & 0.53 & 8\end{array}$

$\begin{array}{llll}225.703 & 0.10 & 5.79 & 9\end{array}$

$\begin{array}{llll}102.592 & 0.04 & 2.63 & 10\end{array}$

$\begin{array}{llll}20.518 & 0.01 & 0.53 & 11\end{array}$

$\begin{array}{llll}287.258 & 0.13 & 7.37 & 12\end{array}$

$\begin{array}{llll}123.111 & 0.05 & 3.16 & 13\end{array}$

$\begin{array}{llll}20.518 & 0.01 & 0.53 & 14\end{array}$

$\begin{array}{llll}61.555 & 0.03 & 1.58 & 15\end{array}$ 


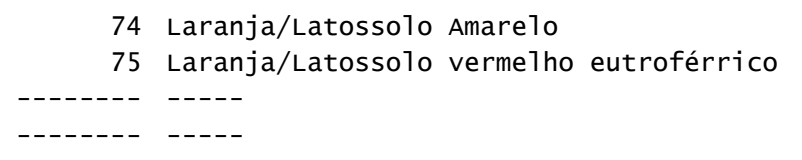

Sub-bacia 5

Uso do solo

Pastagem

Laranja

Solo

Gleissolo

Latossolo Amarelo

HRUS:

76 Pastagem/Gleissolo

77 Pastagem/Latossolo Amarelo

78 Laranja/Latossolo Amarelo

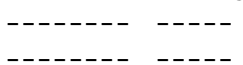

Sub-bacia 6

Uso do solo

Pastagem

Água

Cana-de-açúcar

Mata

Cerrado

Reflorestamento

Área residencial

Agricultura Genérica

Laranja

Solo

Gleissolo

Latossolo Amarelo

Latossolo vermelho eutroférrico

Argissolo

HRUS :

79 Pastagem/Argissolo

80 Pastagem/Gleissolo

81 Pastagem/Latossolo Amarelo

82 Pastagem/Latossolo vermelho eutroférrico

83 Água/Latossolo Amarelo

84 Cana-de-açúcar/Argissolo

85 Cana-de-açúcar/Gleissolo

86 Cana-de-açúcar/Latossolo Amarelo Cana-de-acúcar/Latossolo vermelho

87 eutroférrico

88 Mata/Argissolo

89 Mata/Latossolo Amarelo

90 Mata/Latossolo vermelho eutroférrico

91 Cerrado/Argissolo

92 Cerrado/Latossolo Amarelo

93 Cerrado/Latossolo vermelho eutroférrico

94 Reflorestamento/Latossolo Amarelo Reflorestamento/Latossolo vermelho

95 eutroférrico

96 Área Residencial/Latossolo Amarelo

97 Agricultura Genérica/Argissolo

98 Agricultura Genérica/Latossolo Amarelo Agricultura Genérica/Latossolo vermelho

99 eutroférrico

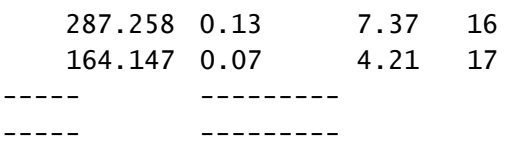

Area [ha] \%Microb. \%Sub-b. N.HRUs

$82.074 \quad 0.04$

$61.555 \quad 0.03 \quad 75.00$

$20.519 \quad 0.01 \quad 25.00$

$\begin{array}{lll}41.037 & 0.02 & 50.00\end{array}$

$41.037 \quad 0.02 \quad 50.00$

$\begin{array}{rlrr}41.037 & 0.02 & 50.00 & 1 \\ 20.519 & 0.01 & 25.00 & 2 \\ 20.519 & 0.01 & 25.00 & 3\end{array}$

Area [ha] \%Microb. \%Sub-b. N.HRUs

$19.328 .352 \quad 8.45$

$\begin{array}{rrr}5.391 .043 & 2.36 & 27.89 \\ 20.896 & 0.01 & 0.11 \\ 4.826 .864 & 2.11 & 24.97 \\ 898.507 & 0.39 & 4.65 \\ 1.525 .373 & 0.67 & 7.89 \\ 41.791 & 0.02 & 0.22 \\ 292.537 & 0.13 & 1.51 \\ 1.880 .596 & 0.82 & 9.73 \\ 4.450 .745 & 1.95 & 23.03\end{array}$

$\begin{array}{lll}229.851 & 0.10 & 1.19\end{array}$

$11.304 .474 \quad 4.94 \quad 58.49$

$2.674 .626 \quad 1.17 \quad 13.84$

$\begin{array}{lll}5.119 .401 & 2.24 & 26.49\end{array}$

$\begin{array}{llll}1.671 .641 & 0.73 & 8.65 & 1\end{array}$

$\begin{array}{llll}41.791 & 0.02 & 0.22 & 2\end{array}$

$\begin{array}{llll}3.468 .656 & 1.52 & 17.95 & 3\end{array}$

$\begin{array}{llll}208.955 & 0.09 & 1.08 & 4\end{array}$

$\begin{array}{llll}20.896 & 0.01 & 0.11 & 5\end{array}$

$\begin{array}{lllll}752.239 & 0.33 & 3.89 & 6\end{array}$

$\begin{array}{llll}83.582 & 0.04 & 0.43 & 7\end{array}$

$\begin{array}{llll}2.549 .253 & 1.11 & 13.19 & 8\end{array}$

$\begin{array}{llll}1.441 .791 & 0.63 & 7.46 & 9\end{array}$

$\begin{array}{llll}522.388 & 0.23 & 2.70 & 10\end{array}$

$\begin{array}{llll}292.537 & 0.13 & 1.51 & 11\end{array}$

$\begin{array}{llll}83.582 & 0.04 & 0.43 & 12\end{array}$

$\begin{array}{llll}731.343 & 0.32 & 3.78 & 13\end{array}$

$\begin{array}{llll}585.074 & 0.26 & 3.03 & 14\end{array}$

$208.955 \quad 0.09 \quad 1.08 \quad 15$

$\begin{array}{llll}20.896 & 0.01 & 0.11 & 16\end{array}$

$\begin{array}{llll}20.896 & 0.01 & 0.11 & 17\end{array}$

$\begin{array}{llll}292.537 & 0.13 & 1.51 & 18\end{array}$

$\begin{array}{llll}104.478 & 0.05 & 0.54 & 19\end{array}$

$\begin{array}{llll}1.734 .328 & 0.76 & 8.97 & 20\end{array}$

$\begin{array}{llll}41.791 & 0.02 & 0.22 & 21\end{array}$ 


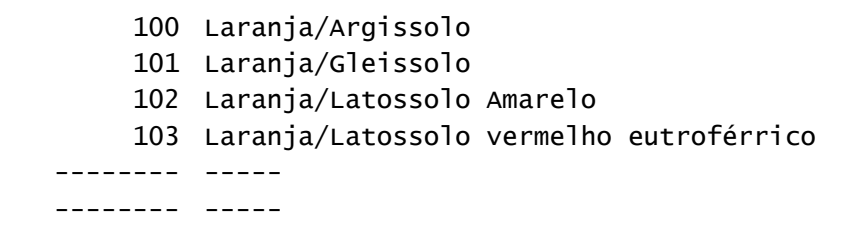

Sub-bacia 7

Uso do solo

Pastagem

Cana-de-açúcar

Mata

Cerrado

Reflorestamento

Agricultura Genérica

Laranja

Solo

Latossolo vermelho eutroférrico

Neossolo Quartzarênico

HRUS:

104 Pastagem/Latossolo vermelho eutroférrico

105 Pastagem/Neossolo Quartzarênico

Cana-de-açúcar/Latossolo vermelho

106 eutroférrico

107 Cana-de-açúcar/Neossolo Quartzarênico

$108 \mathrm{Mata} /$ Latossolo vermelho eutroférrico

109 Mata/Neossolo Quartzarênico

110 Cerrado/Latossolo vermelho eutroférrico

111 Cerrado/Neossolo Quartzarênico Reflorestamento/Latossolo vermelho

112 eutroférrico

Agricultura Genérica/Latossolo vermelho

113 eutroférrico

Agricultura Genérica/Neossolo

114 Quartzarênico

115 Laranja/Latossolo vermelho eutroférrico

116 Laranja/Neossolo Quartzarênico

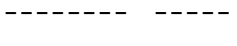

Sub-bacia 8

Uso do solo

Pastagem

Cana-de-açúcar

Mata

Cerrado

Área residencial

Agricultura Genérica

Laranja

Solo

Latossolo Amarelo

Latossolo vermelho eutroférrico

Neossolo Quartzarênico

HRUS:

117 Pastagem/Latossolo Amare1o

118 Pastagem/Latossolo vermelho eutroférrico

119 Pastagem/Neossolo Quartzarênico

120 Cana-de-açúcar/Latossolo Amarelo cana-de-açúcar/Latossolo vermelho

121 eutroférrico

122 Cana-de-açúcar/Neossolo Quartzarênico

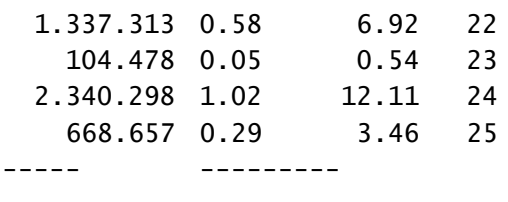

Area [ha] \%Microb. \%Sub-b. N.HRUs

$9.541 .065 \quad 4.17$

$\begin{array}{rrr}1.715 .718 & 0.75 & 17.98 \\ 4.059 .137 & 1.77 & 42.54 \\ 418.468 & 0.18 & 4.39 \\ 1.904 .028 & 0.83 & 19.96 \\ 20.923 & 0.01 & 0.22 \\ 544.008 & 0.24 & 5.70 \\ 878.782 & 0.38 & 9.21\end{array}$

$\begin{array}{lll}4.624 .069 & 2.02 \quad 48.46\end{array}$

$4.916 .996 \quad 2.15 \quad 51.54$

$\begin{array}{llll}606.778 & 0.27 & 6.36 & 1\end{array}$

$\begin{array}{llll}1.108 .940 & 0.48 & 11.62 & 2\end{array}$

$\begin{array}{lllll}1.799 .411 & 0.79 & 18.86 & 3\end{array}$

$\begin{array}{llll}2.259 .726 & 0.99 & 23.68 & 4\end{array}$

$\begin{array}{llll}83.694 & 0.04 & 0.88 & 5\end{array}$

$\begin{array}{llll}334.774 & 0.15 & 3.51 & 6\end{array}$

$\begin{array}{llll}1.464 .637 & 0.64 & 15.35 & 7\end{array}$

$\begin{array}{lllll}439.391 & 0.19 & 4.61 & 8\end{array}$

$\begin{array}{llll}20.923 & 0.01 & 0.22 & 9\end{array}$

$\begin{array}{llll}146.464 & 0.06 & 1.54 & 10\end{array}$

$\begin{array}{llll}397.544 & 0.17 & 4.17 & 11\end{array}$

$\begin{array}{llll}502.161 & 0.22 & 5.26 & 12\end{array}$

$\begin{array}{llll}376.621 & 0.16 & 3.95 & 13\end{array}$

---- --------

Area [ha] \%Microb. \%Sub-b. N.HRUS

$4.534 .571 \quad 1.98$

$1.087 .476 \quad 0.48$

23.98

$\begin{array}{lll}1.395 .253 & 0.61 & 30.77\end{array}$

$\begin{array}{lll}246.221 & 0.11 & 5.43\end{array}$

$\begin{array}{lll}841.255 & 0.37 & 18.55\end{array}$

$\begin{array}{lll}82.074 & 0.04 & 1.81\end{array}$

$\begin{array}{lll}61.555 & 0.03 & 1.36\end{array}$

$\begin{array}{lll}820.737 & 0.36 & 18.10\end{array}$

$2.687 .913 \quad 1.17 \quad 59.28$

$\begin{array}{lll}1.538 .882 & 0.67 & 33.94\end{array}$

$\begin{array}{lll}307.776 & 0.13 & 6.79\end{array}$

$\begin{array}{rrrr}984.884 & 0.43 & 21.72 & 1 \\ 82.074 & 0.04 & 1.81 & 2 \\ 20.518 & 0.01 & 0.45 & 3 \\ 861.774 & 0.38 & 19.00 & 4 \\ 430.887 & 0.19 & 9.50 & 5 \\ 102.592 & 0.04 & 2.26 & 6\end{array}$




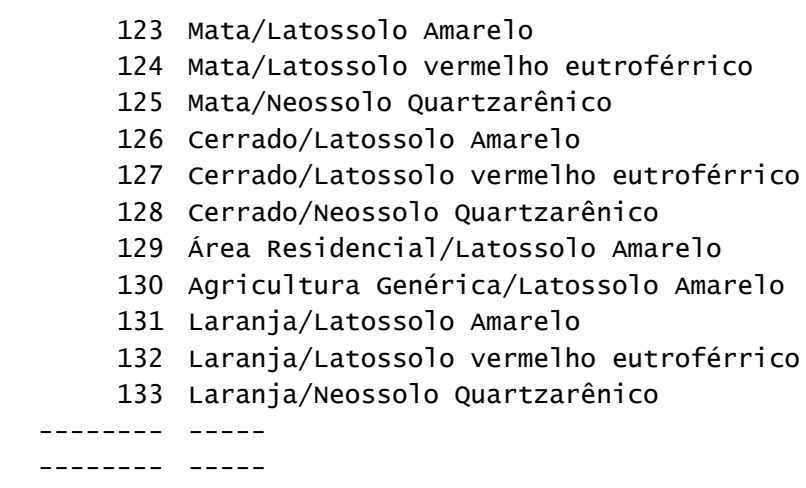

Sub-bacia 9

Uso do solo

Pastagem

Cana-de-açúcar

Mata

Cerrado

Reflorestamento

Agricultura Genérica

Laranja

Solo

Latossolo Amarelo

Neossolo Quartzarênico

HRUS:

134 Pastagem/Latossolo Amarelo

135 Pastagem/Neossolo Quartzarênico

136 Cana-de-açúcar/Latossolo Amarelo

137 Cana-de-açúcar/Neossolo Quartzarênico

138 Mata/Latossolo Amarelo

139 Mata/Neossolo Quartzarênico

140 Cerrado/Latossolo Amarelo

141 Cerrado/Neossolo Quartzarênico

142 Reflorestamento/Latossolo Amarelo

143 Reflorestamento/Neossolo Quartzarênico

144 Agricultura Genérica/Latossolo Amarelo Agricultura Genérica/Neossolo

145 Quartzarênico

146 Laranja/Latossolo Amarelo

147 Laranja/Neossolo Quartzarênico

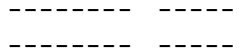

Sub-bacia 10

Uso do solo

Pastagem

Cana-de-açúcar

Mata

Cerrado

Reflorestamento

Área residencial

Agricultura Genérica

Laranja

Solo

Gleissolo

Latossolo Amarelo

Neossolo Litólico

Neossolo Quartzarênico

$\begin{array}{rlrr}82.074 & 0.04 & 1.81 & 7 \\ 61.555 & 0.03 & 1.36 & 8 \\ 102.592 & 0.04 & 2.26 & 9 \\ 266.739 & 0.12 & 5.88 & 10 \\ 533.479 & 0.23 & 11.76 & 11 \\ 41.037 & 0.02 & 0.90 & 12 \\ 82.074 & 0.04 & 1.81 & 13 \\ 61.555 & 0.03 & 1.36 & 14 \\ 348.813 & 0.15 & 7.69 & 15 \\ 430.887 & 0.19 & 9.50 & 16 \\ 41.037 & 0.02 & 0.90 & 17\end{array}$

Area [ha] \%Microb. \%Sub-b. N.HRUS

$9.007 .586 \quad 3.94$

$\begin{array}{rrr}2.889 .652 & 1.26 & 32.08 \\ 1.151 .346 & 0.50 & 12.78 \\ 180.603 & 0.08 & 2.01 \\ 812.715 & 0.36 & 9.02 \\ 90.302 & 0.04 & 1.00 \\ 1.580 .278 & 0.69 & 17.54 \\ 2.302 .691 & 1.01 & 25.56\end{array}$

$\begin{array}{lll}3.070 .255 & 1.34 & 34.09\end{array}$

$5.937 .331 \quad 2.60 \quad 65.91$

$\begin{array}{rrrr}835.290 & 0.37 & 9.27 & 1 \\ 2.054 .362 & 0.90 & 22.81 & 2 \\ 835.290 & 0.37 & 9.27 & 3 \\ 316.056 & 0.14 & 3.51 & 4 \\ 22.575 & 0.01 & 0.25 & 5 \\ 158.028 & 0.07 & 1.75 & 6 \\ 451.508 & 0.20 & 5.01 & 7 \\ 361.206 & 0.16 & 4.01 & 8 \\ 22.575 & 0.01 & 0.25 & 9 \\ 67.726 & 0.03 & 0.75 & 10 \\ 519.234 & 0.23 & 5.76 & 11 \\ 1.061 .044 & 0.46 & 11.78 & 12 \\ 383.782 & 0.17 & 4.26 & 13 \\ 1.918 .909 & 0.84 & 21.30 & 14\end{array}$

$----\quad-------$

Area [ha] \%Microb. \%Sub-b. N.HRUs

$5.375 .826 \quad 2.35$ $\begin{array}{rrr}923.329 & 0.40 & 17.18 \\ .180 .355 & 1.39 & 59.16 \\ 800.218 & 0.35 & 14.89 \\ 471.924 & 0.21 & 8.78\end{array}$ 


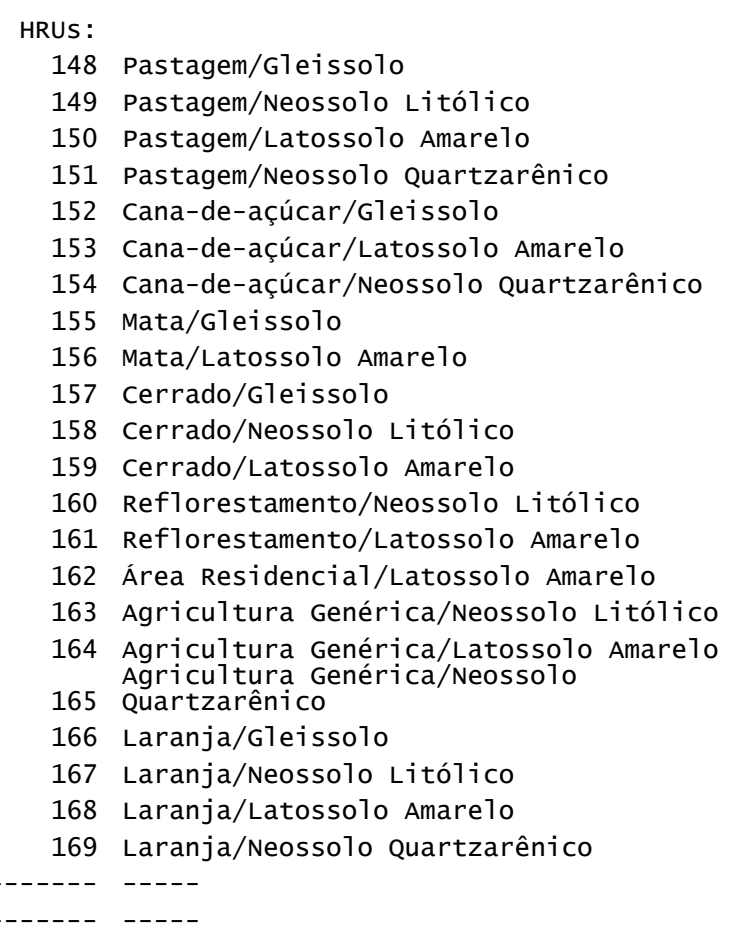

Sub-bacia 11

Uso do solo

Pastagem

Cana-de-açúcar

Mata

Cerrado

Reflorestamento

Agricultura Genérica

Laranja

Solo

Gleissolo

Latossolo Amarelo

Neossolo Litólico

Latossolo vermelho eutroférrico

Argissolo

Neossolo Quartzarênico

Latossolo vermelho mesoférrico

HRUS:

170 Pastagem/Argissolo

171 Pastagem/Gleissolo

172 Pastagem/Neossolo Litólico

173 Pastagem/Latossolo Amarelo

174 Pastagem/Latossolo vermelho eutroférrico

175 Pastagem/Latossolo vermelho mesoférrico

176 Pastagem/Neossolo Quartzarênico

177 Cana-de-açúcar/Argissolo

178 Cana-de-açúcar/Gleissolo

179 Cana-de-açúcar/Neossolo Litólico

180 Cana-de-açúcar/Latossolo Amarelo Cana-de-açúcar/Latossolo vermelho

181 eutroférriçco

Cana-de-acúcar/Latossolo vermelho

182 mesoférrico

183 Cana-de-açúcar/Neossolo Quartzarênico

184 Mata/Argissolo

185 Mata/Neossolo Litólico

$\begin{array}{rlrr}636.071 & 0.28 & 11.83 & 1 \\ 512.960 & 0.22 & 9.54 & 2 \\ 1.415 .771 & 0.62 & 26.34 & 3 \\ 246.221 & 0.11 & 4.58 & 4 \\ 82.074 & 0.04 & 1.53 & 5 \\ 820.737 & 0.36 & 15.27 & 6 \\ 20.518 & 0.01 & 0.38 & 7 \\ 20.518 & 0.01 & 0.38 & 8 \\ 20.518 & 0.01 & 0.38 & 9 \\ 123.111 & 0.05 & 2.29 & 10 \\ 184.666 & 0.08 & 3.44 & 11 \\ 307.776 & 0.13 & 5.73 & 12 \\ 20.518 & 0.01 & 0.38 & 13 \\ 20.518 & 0.01 & 0.38 & 14 \\ 61.555 & 0.03 & 1.15 & 15 \\ 20.518 & 0.01 & 0.38 & 16 \\ 328.295 & 0.14 & 6.11 & 17 \\ 41.037 & 0.02 & 0.76 & 18 \\ 61.555 & 0.03 & 1.15 & 19 \\ 61.555 & 0.03 & 1.15 & 20 \\ 205.184 & 0.09 & 3.82 & 21 \\ 164.147 & 0.07 & 3.05 & 22 \\ ---- & ------- & & \end{array}$

Area [ha] \%Microb. \%Sub-b. N.HRUs

$25.217 .138 \quad 11.02$

$\begin{array}{rrrr}684.347 & 0.30 & 2.71 & 1 \\ 124.427 & 0.05 & 0.49 & 2 \\ 124.427 & 0.05 & 0.49 & 3 \\ 622.133 & 0.27 & 2.47 & 4 \\ 145.164 & 0.06 & 0.58 & 5 \\ 870.987 & 0.38 & 3.45 & 6 \\ .534 .596 & 0.67 & 6.09 & 7 \\ 311.067 & 0.14 & 1.23 & 8 \\ 20.738 & 0.01 & 0.08 & 9 \\ 269.591 & 0.12 & 1.07 & 10 \\ .006 .978 & 1.31 & 11.92 & 11 \\ .016 .151 & 0.44 & 4.03 & 12 \\ .327 .218 & 0.58 & 5.26 & 13 \\ 912.462 & 0.40 & 3.62 & 14 \\ 580.658 & 0.25 & 2.30 & 15 \\ 20.738 & 0.01 & 0.08 & 16\end{array}$

$\begin{array}{rrr}1.016 .151 & 0.44 & 4.03 \\ 9.560 .116 & 4.18 & 37.91 \\ 995.413 & 0.44 & 3.95 \\ 3.483 .947 & 1.52 & 13.82 \\ 3.131 .404 & 1.37 & 12.42 \\ 3.131 .404 & 1.37 & 12.42 \\ 3.898 .702 & 1.70 & 15.46\end{array}$

$4.106 .080 \quad 1.79 \quad 16.28$

$6.864 .205 \quad 3.00 \quad 27.22$

$\begin{array}{lll}1.347 .956 & 0.59 & 5.35\end{array}$

$3.421 .733 \quad 1.50 \quad 13.57$

$\begin{array}{lll}248.853 & 0.11 & 0.99\end{array}$

$\begin{array}{lll}1.555 .333 & 0.68 & 6.17\end{array}$

$\begin{array}{lll}7.672 .978 & 3.35 & 30.43\end{array}$ 


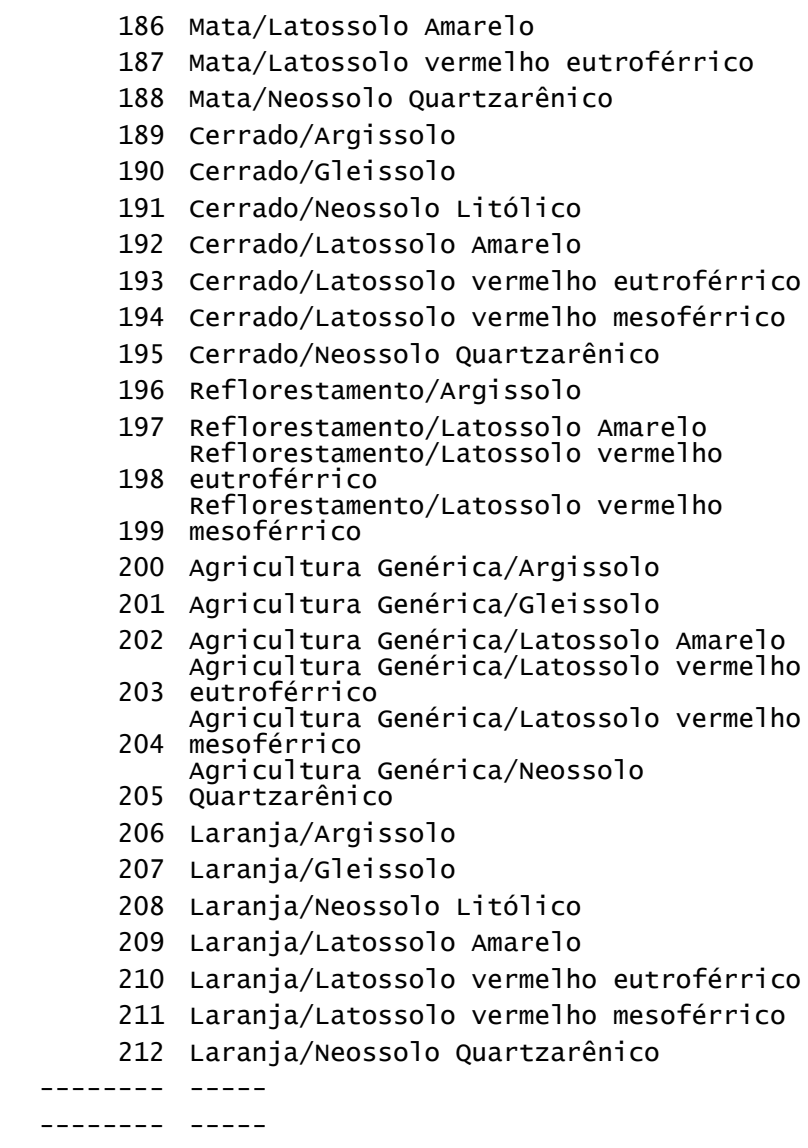

Sub-bacia 12

Uso do solo

Pastagem

Água

Cana-de-açúcar

Mata

Cerrado

Agricultura Genérica

Laranja

Solo

Latossolo Amarelo

HRUS:

213 Pastagem/Latossolo Amare1o

214 Água/Latossolo Amarelo

215 Cana-de-açúcar/Latossolo Amarelo

216 Mata/Latossolo Amarelo

217 Cerrado/Latossolo Amarelo

218 Agricultura Genérica/Latossolo Amare1o

219 Laranja/Latossolo Amarelo

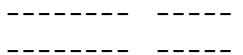

Sub-bacia 13

$\begin{array}{rrrr}476.969 & 0.21 & 1.89 & 17 \\ 207.378 & 0.09 & 0.82 & 18 \\ 62.213 & 0.03 & 0.25 & 19 \\ 622.133 & 0.27 & 2.47 & 20 \\ 82.951 & 0.04 & 0.33 & 21 \\ 248.853 & 0.11 & 0.99 & 22 \\ 953.938 & 0.42 & 3.78 & 23 \\ 767.298 & 0.34 & 3.04 & 24 \\ 622.133 & 0.27 & 2.47 & 25 \\ 124.427 & 0.05 & 0.49 & 26 \\ 124.427 & 0.05 & 0.49 & 27 \\ 62.213 & 0.03 & 0.25 & 28 \\ 41.476 & 0.02 & 0.16 & 29 \\ 20.738 & 0.01 & 0.08 & 30 \\ 20.738 & 0.01 & 0.08 & 31 \\ 62.213 & 0.03 & 0.25 & 32 \\ 1.016 .151 & 0.44 & 4.03 & 33 \\ 41.476 & 0.02 & 0.16 & 34 \\ 103.689 & 0.05 & 0.41 & 35 \\ 311.067 & 0.14 & 1.23 & 36 \\ 788.036 & 0.34 & 3.12 & 37 \\ 725.822 & 0.32 & 2.88 & 38 \\ 331.804 & 0.15 & 1.32 & 39 \\ 3.421 .733 & 1.50 & 13.57 & 40 \\ 1.265 .004 & 0.55 & 5.02 & 41 \\ 953.938 & 0.42 & 3.78 & 42 \\ 186.640 & 0.08 & 0.74 & 43\end{array}$

(1)

Area [ha] \%Microb. \%Sub-b. N.HRUs

$9.746 .249 \quad 4.26$

$\begin{array}{rrr}1.028 .628 & 0.45 & 10.55 \\ 51.431 & 0.02 & 0.53 \\ 4.320 .237 & 1.89 & 44.33 \\ 231.441 & 0.10 & 2.37 \\ 900.049 & 0.39 & 9.23 \\ 694.324 & 0.30 & 7.12 \\ 2.520 .138 & 1.10 & 25.86\end{array}$

$9.746 .249 \quad 4.26 \quad 100.00$

$\begin{array}{rlrr}1.028 .628 & 0.45 & 10.55 & 1 \\ 51.431 & 0.02 & 0.53 & 2 \\ 4.320 .237 & 1.89 & 44.33 & 3 \\ 231.441 & 0.10 & 2.37 & 4 \\ 900.049 & 0.39 & 9.23 & 5 \\ 694.324 & 0.30 & 7.12 & 6 \\ 2.520 .138 & 1.10 & 25.86 & 7 \\ - & ------ & & \end{array}$

Area [ha] \%Microb. \%Sub-b. N.HRUS

$7.366 .113 \quad 3.22$ 
Reflorestamento

Área residencial

Agricultura Genérica

Laranja

Solo

Latossolo Amarelo

Neossolo Litólico

Latossolo vermelho eutroférrico

Neossolo Quartzarênico

Latossolo vermelho mesoférrico

HRUS:

220 Pastagem/Neossolo Litólico

221 Pastagem/Latossolo Amarelo

222 Pastagem/Latossolo vermelho eutroférrico

223 Pastagem/Latossolo vermelho mesoférrico

224 Pastagem/Neossolo Quartzarênico

225 Cana-de-açúcar/Neossolo Litólico

226 Cana-de-açúcar/Latossolo Amarelo Cana-de-acúcar/Latossolo vermelho

eutroférrico

Cana-de-açúcar/Latossolo vermelho

228 mesoférriço

229 Cana-de-açúcar/Neossolo Quartzarênico

230 Mata/Latossolo vermelho mesoférrico

231 Mata/Neossolo Quartzarênico

232 Cerrado/Latossolo Amarelo

233 Cerrado/Latossolo vermelho eutroférrico

234 Cerrado/Latossolo vermelho mesoférrico

235 Cerrado/Neossolo Quartzarênico Reflorestamento/Latossolo vermelho

236 eutroférrico

237 Área Residencial/Latossolo Amarelo Área Residencial/Latossolo vermelho

238 eutroférrico

Área Residencial/Latossolo vermelho

239 mesoférrico

240 Área Residencial/Neossolo Quartzarênico

241 Agricultura Genérica/Latossolo Amarelo Agricultura Genérica/Latossolo vermelho mesoférrico

242 mesoférrico

Agricultura Genérica/Neossolo

243 Quartzarênico

244 Laranja/Latossolo Amarelo

245 Laranja/Latossolo vermelho eutroférrico

246 Laranja/Latossolo vermelho mesoférrico

247 Laranja/Neossolo Quartzarênico

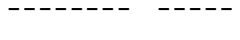

Sub-bacia 14

Uso do solo

Pastagem

Cana-de-açúcar

Mata

Cerrado

Reflorestamento

Área residencial

Agricultura Genérica

Laranja

Solo

Latossolo Amarelo

Neossolo Litólico

Latossolo vermelho eutroférrico

Neossolo Quartzarênico

Latossolo vermelho mesoférrico
$21.729 \quad 0.01$

$1.999 .063 \quad 0.87$

$412.850 \quad 0.18$

1.607 .9420 .70

27.14

5.60

21.83

$1.368 .924 \quad 0.60$

$43.458 \quad 0.02$

18.58

0.59

$1.260 .279 \quad 0.55$

$3.237 .613 \quad 1.42$

17.11

1.455 .8390 .64

19.76

$21.729 \quad 0.01$

108.6450 .05

$0.29 \quad 1$

$152.103 \quad 0.07$

$21.729 \quad 0.01$

$434.579 \quad 0.19$

$21.729 \quad 0.01$

$152.103 \quad 0.07$

1.472

2.063

0.294

$5.90 \quad 5$

0.296

$391.121 \quad 0.17$

2.067

$391.121 \quad 0.17$

$1.151 .634 \quad 0.50$

$21.729 \quad 0.01$

$\begin{array}{lll}65.187 & 0.03\end{array}$

$43.458 \quad 0.02$

5.318

5.319

15.6310

$0.29 \quad 11$

$0.88 \quad 12$

$43.458 \quad 0.02$

0.5913

$\begin{array}{llll}282.476 & 0.12 & 3.83 & 16\end{array}$

$\begin{array}{llll}21.729 & 0.01 & 0.29 & 17\end{array}$

$\begin{array}{llll}869.158 & 0.38 & 11.80 & 18\end{array}$

$\begin{array}{llll}543.224 & 0.24 & 7.37 & 19\end{array}$

$\begin{array}{llll}521.495 & 0.23 & 7.08 & 20\end{array}$

$\begin{array}{llll}65.187 & 0.03 & 0.88 & 21\end{array}$

$\begin{array}{llll}21.729 & 0.01 & 0.29 & 22\end{array}$

$\begin{array}{llll}108.645 & 0.05 & 1.47 & 23\end{array}$

$\begin{array}{llll}282.476 & 0.12 & 3.83 & 24\end{array}$

$\begin{array}{llll}173.832 & 0.08 & 2.36 & 25\end{array}$

$\begin{array}{llll}108.645 & 0.05 & 1.47 & 26\end{array}$

$\begin{array}{llll}369.392 & 0.16 & 5.01 & 27\end{array}$

$\begin{array}{llll}956.074 & 0.42 & 12.98 & 28\end{array}$

$-----1------$

Area [ha] \%Microb. \%Sub-b. N.HRUs

$5.724 .639 \quad 2.50$

$\begin{array}{lll}90.152 & 0.04 & 1.57\end{array}$

$\begin{array}{lll}924.056 & 0.40 \quad 16.14\end{array}$

$90.152 \quad 0.04 \quad 1.57$

$202.842 \quad 0.09 \quad 3.54$

$\begin{array}{lll}90.152 & 0.04 & 1.57\end{array}$

$\begin{array}{lll}3.786 .375 & 1.66 & 66.14\end{array}$

$\begin{array}{lll}180.304 & 0.08 & 3.15\end{array}$

$\begin{array}{lll}360.607 & 0.16 & 6.30\end{array}$

$3.087 .699 \quad 1.35 \quad 53.94$

$\begin{array}{lll}22.538 & 0.01 & 0.39\end{array}$

$\begin{array}{lll}360.607 & 0.16 & 6.30\end{array}$

$\begin{array}{lll}631.063 & 0.28 & 11.02\end{array}$

$\begin{array}{lll}1.622 .732 & 0.71 & 28.35\end{array}$ 


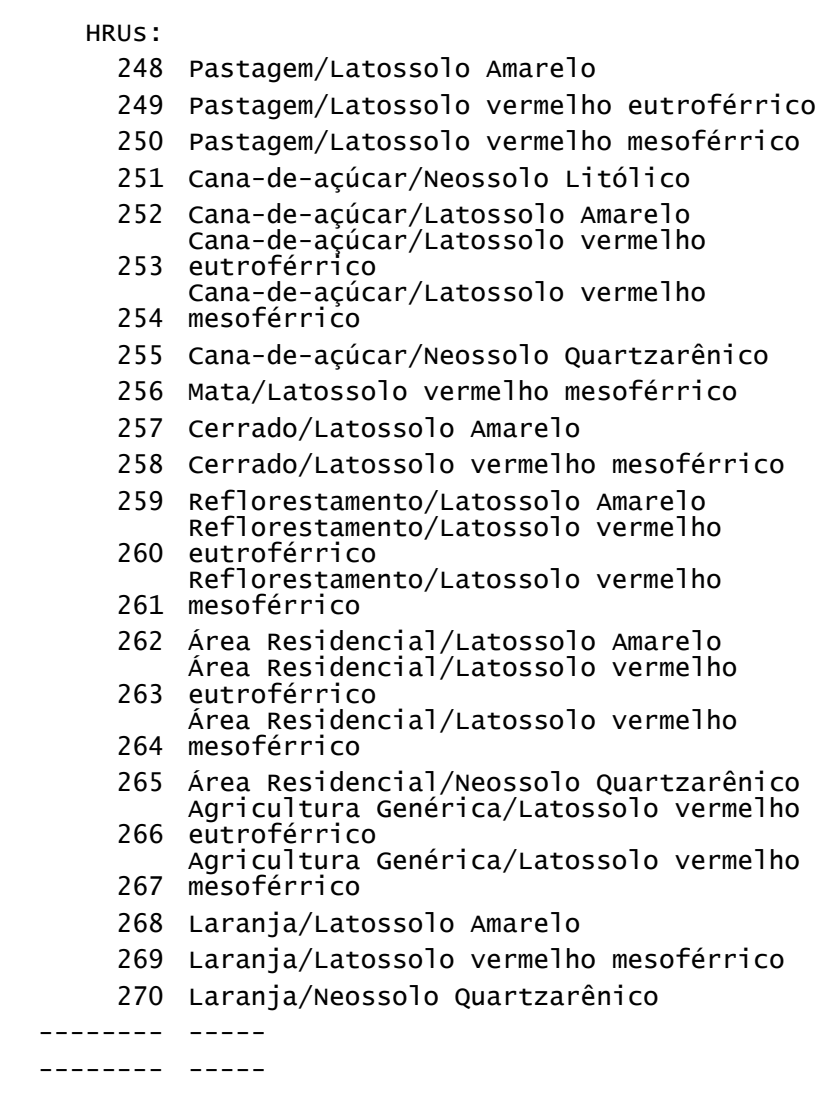

Sub-bacia 15

Uso do solo

Pastagem

Cana-de-açúcar

Cerrado

Área residencial

Agricultura Genérica

Laranja

Solo

Latossolo Amarelo

Neossolo Quartzarênico

HRUS:

271 Pastagem/Latossolo Amare1o

272 Pastagem/Neossolo Quartzarênico

273 Cana-de-açúcar/Latossolo Amarelo

274 Cana-de-açúcar/Neossolo Quartzarênico

275 Cerrado/Latossolo Amarelo

276 Área Residencial/Latossolo Amarelo

Agricultura Genérica/Neossolo

277 Quartzarênico

278 Laranja/Latossolo Amarelo

279 Laranja/Neossolo Quartzarênico

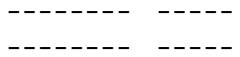

Sub-bacia 16

\begin{tabular}{|c|c|c|c|}
\hline 22.538 & 0.01 & 0.39 & 1 \\
\hline 45.076 & 0.02 & 0.79 & 2 \\
\hline 22.538 & 0.01 & 0.39 & 3 \\
\hline 22.538 & 0.01 & 0.39 & + \\
\hline 112.690 & 0.05 & 1.97 & 5 \\
\hline 157.766 & 0.07 & 2.76 & 6 \\
\hline 608.525 & 0.27 & 10.63 & 7 \\
\hline 22.538 & 0.01 & 0.39 & 8 \\
\hline 90.152 & 0.04 & 1.57 & 9 \\
\hline 157.766 & 0.07 & 2.76 & 10 \\
\hline 45.076 & 0.02 & 0.79 & 11 \\
\hline 22.538 & 0.01 & 0.39 & 12 \\
\hline 22.538 & 0.01 & 0.39 & 13 \\
\hline 45.076 & 0.02 & 0.79 & 14 \\
\hline 2.704 .554 & 1.18 & 47.24 & 15 \\
\hline 112.690 & 0.05 & 1.97 & 16 \\
\hline 383.145 & 0.17 & 6.69 & 17 \\
\hline 585.987 & 0.26 & 10.24 & 18 \\
\hline 22.538 & 0.01 & 0.39 & 19 \\
\hline 157.766 & 0.07 & 2.76 & 20 \\
\hline 67.614 & 0.03 & 1.18 & 21 \\
\hline 270.455 & 0.12 & 4.72 & 22 \\
\hline 22.538 & 0.01 & 0.39 & 23 \\
\hline & & & \\
\hline
\end{tabular}

Area [ha] \%Microb. \%Sub-b. N.HRUs

$2.277 .544 \quad 1.00$

$\begin{array}{rrr}595.034 & 0.26 & 26.13 \\ 307.776 & 0.13 & 13.51 \\ 328.295 & 0.14 & 14.41 \\ 820.737 & 0.36 & 36.04 \\ 41.037 & 0.02 & 1.80 \\ 184.666 & 0.08 & 8.11 \\ & & \\ & & \\ 072.360 & 0.91 & 90.99 \\ 205.184 & 0.09 & 9.01\end{array}$

$\begin{array}{rrrr}553.997 & 0.24 & 24.32 & 1 \\ 41.037 & 0.02 & 1.80 & 2 \\ 225.703 & 0.10 & 9.91 & 3 \\ 82.074 & 0.04 & 3.60 & 4 \\ 328.295 & 0.14 & 14.41 & 5 \\ 820.737 & 0.36 & 36.04 & 6 \\ 41.037 & 0.02 & 1.80 & 7 \\ 143.629 & 0.06 & 6.31 & 8 \\ 41.037 & 0.02 & 1.80 & 9\end{array}$

---- -------

Area [ha] \%Microb. \%Sub-b. N.HRUs

$2.893 .097 \quad 1.26$

$697.626 \quad 0.30$

24.11

Pastagem

Cana-de-açúcar
$307.776 \quad 0.13 \quad 10.64$ 
Mata

Cerrado

Área residencial

Agricultura Genérica

Laranja

Solo

Latossolo Amarelo

Neossolo Quartzarênico

HRUS:

280 Pastagem/Latossolo Amarelo

281 Pastagem/Neossolo Quartzarênico

282 Cana-de-açúcar/Latossolo Amarelo

283 Cana-de-açúcar/Neossolo Quartzarênico

284 Mata/Latossolo Amarelo

285 Cerrado/Latossolo Amarelo

286 Cerrado/Neossolo Quartzarênico

287 Área Residencial/Latossolo Amarelo

288 Agricultura Genérica/Latossolo Amarelo Agricultura Genérica/Neossolo

289 Quartzarênico

290 Laranja/Latossolo Amarelo

291 Laranja/Neossolo Quartzarênico

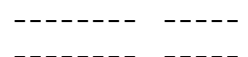

Sub-bacia 17

Uso do solo

Pastagem

Água

Cana-de-açúcar

Mata

Cerrado

Reflorestamento

Agricultura Genérica

Laranja

Solo

Gleissolo

Latossolo Amarelo

Neossolo Quartzarênico

HRUS:

292 Pastagem/Latossolo Amarelo

293 Pastagem/Neossolo Quartzarênico

294 Água/Neossolo Quartzarênico

295 Cana-de-açúcar/Latossolo Amarelo

296 Cana-de-açúcar/Neossolo Quartzarênico

297 Mata/Latossolo Amarelo

298 Mata/Neossolo Quartzarênico

299 Cerrado/Gleissolo

300 Cerrado/Latossolo Amarelo

301 Cerrado/Neossolo Quartzarênico

302 Reflorestamento/Neossolo Quartzarênico

303 Agricultura Genérica/Latossolo Amarelo Agricultura Genérica/Neossolo

304 Quartzarênico

305 Laranja/Latossolo Amarelo

306 Laranja/Neossolo Quartzarênico
123.1110 .05

$307.776 \quad 0.13$

$\begin{array}{ll}738.663 & 0.32\end{array}$

$287.258 \quad 0.13$

$430.887 \quad 0.19$

4.26

10.64

25.53

9.93

14.89

$2.646 .876 \quad 1.16$

91.49

$246.221 \quad 0.11$

8.51

$615.553 \quad 0.27$

$82.074 \quad 0.04$

$21.28 \quad 1$

$287.258 \quad 0.13$

$20.518 \quad 0.01$

2.84

9.93

123.1110 .05

$287.258 \quad 0.13$

$20.518 \quad 0.01$

$\begin{array}{ll}738.663 & 0.32\end{array}$

$184.666 \quad 0.08$

$0.71 \quad 4$

$4.26 \quad 5$

9.936

0.717

$\begin{array}{rr}0.71 & 7 \\ 25.53 & 8\end{array}$

$\begin{array}{llll}410.368 & 0.18 & 14.18 & 11\end{array}$

$\begin{array}{llll}20.518 & 0.01 & 0.71 & 12\end{array}$

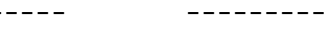

Area [ha] \%Microb. \%Sub-b. N.HRUs

$4.924 .421 \quad 2.15$

$\begin{array}{rrr}1.415 .771 & 0.62 & 28.75 \\ 20.518 & 0.01 & 0.42 \\ 1.025 .921 & 0.45 & 20.83 \\ 123.111 & 0.05 & 2.50 \\ 882.292 & 0.39 & 17.92 \\ 184.666 & 0.08 & 3.75 \\ 451.405 & 0.20 & 9.17 \\ 820.737 & 0.36 & 16.67\end{array}$

$\begin{array}{lll}20.518 & 0.01 & 0.42\end{array}$

$\begin{array}{lll}656.589 & 0.29 & 13.33\end{array}$

$\begin{array}{lll}4.247 .313 & 1.86 & 86.25\end{array}$

$\begin{array}{rlrc}123.111 & 0.05 & 2.50 & 1 \\ 1.292 .661 & 0.57 & 26.25 & 2 \\ 20.518 & 0.01 & 0.42 & 3 \\ 82.074 & 0.04 & 1.67 & 4 \\ 943.847 & 0.41 & 19.17 & 5 \\ 20.518 & 0.01 & 0.42 & 6 \\ 102.592 & 0.04 & 2.08 & 7 \\ 20.518 & 0.01 & 0.42 & 8 \\ 287.258 & 0.13 & 5.83 & 9 \\ 574.516 & 0.25 & 11.67 & 10 \\ 184.666 & 0.08 & 3.75 & 11 \\ 61.555 & 0.03 & 1.25 & 12 \\ 389.850 & 0.17 & 7.92 & 13 \\ 82.074 & 0.04 & 1.67 & 14 \\ 738.663 & 0.32 & 15.00 & 15 \\ ---- & ------- & \\ ---- & \text {------- } & \\ \text { Area [ha] } & \% \text { Microb. } \% \text { Sub-b. N.HRUs }\end{array}$

$102.592 \quad 0.04$ 


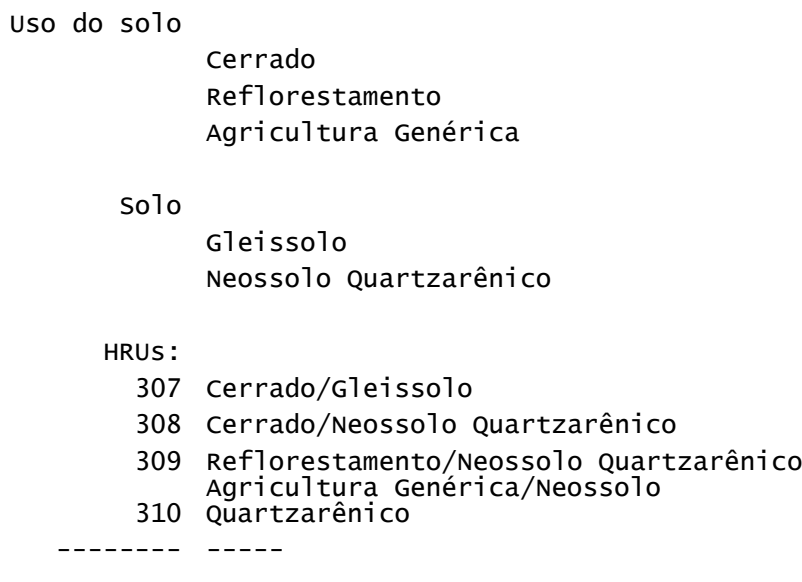

Uso do solo

Pastagem

Cana-de-açúcar

Mata

Cerrado

Reflorestamento

Agricultura Genérica

Laranja $\begin{array}{lll}41.037 & 0.02 & 40.00 \\ 20.518 & 0.01 & 20.00 \\ 41.037 & 0.02 & 40.00\end{array}$

$\begin{array}{lll}20.518 & 0.01 \quad 20.00\end{array}$

$82.074 \quad 0.04 \quad 80.00$

$\begin{array}{llll}20.518 & 0.01 & 20.00 & 1 \\ 20.518 & 0.01 & 20.00 & 2 \\ 20.518 & 0.01 & 20.00 & 3 \\ 41.037 & 0.02 & 40.00 & 4\end{array}$

Area [ha] $\%$ microb. \%Sub-b. N.HRUS

$7.858 .555 \quad 3.44$

$339.567 \quad 0.15$

4.32

$1.042 .956 \quad 0.46$

13.27

$3.565 .456 \quad 1.56$

$\begin{array}{ll}945.937 & 0.41\end{array}$

45.37

$\begin{array}{lll}388.077 & 0.17 & 4.94\end{array}$

$\begin{array}{lll}533.606 & 0.23 \quad 6.79\end{array}$

$\begin{array}{lll}1.042 .956 & 0.46 \quad 13.27\end{array}$

$\begin{array}{lll}121.274 & 0.05 & 1.54\end{array}$

$\begin{array}{lll}1.600 .817 & 0.70 & 20.37\end{array}$

$\begin{array}{lll}6.136 .464 & 2.68 \quad 78.09\end{array}$

$\begin{array}{rrrr}339.567 & 0.15 & 4.32 & 1 \\ 776.154 & 0.34 & 9.88 & 2 \\ 266.803 & 0.12 & 3.40 & 3 \\ 460.841 & 0.20 & 5.86 & 4 \\ 3.104 .614 & 1.36 & 39.51 & 5 \\ 24.255 & 0.01 & 0.31 & 6 \\ 266.803 & 0.12 & 3.40 & 7 \\ 654.880 & 0.29 & 8.33 & 8 \\ 48.510 & 0.02 & 0.62 & 9 \\ 339.567 & 0.15 & 4.32 & 10 \\ 97.019 & 0.04 & 1.23 & 11 \\ 436.586 & 0.19 & 5.56 & 12 \\ 48.510 & 0.02 & 0.62 & 13 \\ 994.447 & 0.43 & 12.65 & 14\end{array}$

Area [ha] \%Microb. \%Sub-b. N.HRUs

$3.282 .947 \quad 1.44$ 
Solo

Gleissolo

Latossolo Amare1o

$471.924 \quad 0.21$

14.38

Latossolo vermelho eutroférrico

$123.111 \quad 0.05$

3.75

Neossolo Quartzarênico

$\begin{array}{lll}61.555 & 0.03 & 1.88\end{array}$

Latossolo vermelho mesoférrico

$\begin{array}{lll}1.354 .216 & 0.59 & 41.25\end{array}$

$1.272 .142 \quad 0.56 \quad 38.75$

HRUS:

325 Pastagem/Latossolo Amare1o

326 Pastagem/Latossolo vermelho eutroférrico

327 Pastagem/Latossolo vermelho mesoférrico

328 Pastagem/Neossolo Quartzarênico

329 Cana-de-açúcar/Gleissolo

330 Cana-de-açúcar/Latossolo Amarelo Cana-de-açúcar/Latossolo vermelho

331 eutroférrico

Cana-de-açúcar/Latossolo vermelho

332 mesoférrico

333 Cana-de-açúcar/Neossolo Quartzarênico

334 Mata/Gleissolo

335 Mata/Neossolo Quartzarênico

336 Cerrado/Gleissolo

337 Cerrado/Latossolo vermelho mesoférrico

338 Cerrado/Neossolo Quartzarênico

Reflorestamento/Latossolo vermelho

339 mesoférrico

340 Agricultura Genérica/Gleissolo Agricultura Genérica/Latossolo vermelho

341 mesoférrico

Agricultura Genérica/Neossolo

342 Quartzarênico

343 Laranja/Gleissolo

344 Laranja/Latossolo Amare1o

345 Laranja/Latossolo vermelho eutroférrico

346 Laranja/Latossolo vermelho mesoférrico

347 Laranja/Neossolo Quartzarênico

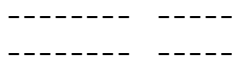

Sub-bacia 21

$\begin{array}{llll}61.555 & 0.03 & 1.87 & 1\end{array}$

$\begin{array}{llll}20.518 & 0.01 & 0.63 & 2\end{array}$

$\begin{array}{llll}410.368 & 0.18 & 12.50 & 3\end{array}$

$\begin{array}{llll}123.111 & 0.05 & 3.75 & 4\end{array}$

$\begin{array}{llll}41.037 & 0.02 & 1.25 & 5\end{array}$

$\begin{array}{llll}41.037 & 0.02 & 1.25 & 6\end{array}$

$\begin{array}{llll}20.518 & 0.01 & 0.63 & 7\end{array}$

$\begin{array}{llll}328.295 & 0.14 & 10.00 & 8\end{array}$

$\begin{array}{llll}553.997 & 0.24 & 16.87 & 9\end{array}$

$\begin{array}{llll}20.518 & 0.01 & 0.63 & 10\end{array}$

$\begin{array}{llll}102.592 & 0.04 & 3.12 & 11\end{array}$

$\begin{array}{llll}184.666 & 0.08 & 5.62 & 12\end{array}$

$\begin{array}{llll}41.037 & 0.02 & 1.25 & 13\end{array}$

$\begin{array}{llll}164.147 & 0.07 & 5.00 & 14\end{array}$

$\begin{array}{llll}20.518 & 0.01 & 0.63 & 15\end{array}$

$\begin{array}{llll}184.666 & 0.08 & 5.62 & 16\end{array}$

$\begin{array}{llll}61.555 & 0.03 & 1.87 & 17\end{array}$

$\begin{array}{llll}369.332 & 0.16 & 11.25 & 18\end{array}$

$\begin{array}{llll}41.037 & 0.02 & 1.25 & 19\end{array}$

$\begin{array}{llll}20.518 & 0.01 & 0.63 & 20\end{array}$

$\begin{array}{llll}20.518 & 0.01 & 0.63 & 21\end{array}$

$\begin{array}{llll}410.368 & 0.18 & 12.50 & 22\end{array}$

$\begin{array}{llll}41.037 & 0.02 & 1.25 & 23\end{array}$

--- -------

Area [ha] \%Microb. \%Sub-b. N.HRUs

$1.374 .734 \quad 0.60$

Uso do solo

Mata

Cerrado

Agricu1tura Genérica

Laranja

$\begin{array}{rrr}164.147 & 0.07 & 11.94 \\ 41.037 & 0.02 & 2.99 \\ 1.025 .921 & 0.45 & 74.63 \\ 143.629 & 0.06 & 10.45\end{array}$

Solo

Gleissolo

Latossolo vermelho eutroférrico

Latossolo vermelho mesoférrico

Neossolo Quartzarênico

$\begin{array}{rrr}287.258 & 0.13 & 20.90 \\ 102.592 & 0.04 & 7.46 \\ 20.518 & 0.01 & 1.49 \\ 964.366 & 0.42 & 70.15\end{array}$

HRUS:

348 Mata/Neossolo Quartzarênico

349 Cerrado/Gleissolo

350 Cerrado/Neossolo Quartzarênico

351 Agricultura Genérica/Gleissolo

Agricultura Genérica/Neossolo

352 Quartzarênico

353 Laranja/Gleissolo

354 Laranja/Latossolo vermelho eutroférrico

355 Laranja/Latossolo verme1ho mesoférrico

\begin{tabular}{rlrl}
164.147 & 0.07 & 11.94 & 1 \\
20.518 & 0.01 & 1.49 & 2 \\
20.518 & 0.01 & 1.49 & 3 \\
246.221 & 0.11 & 17.91 & 4 \\
779.700 & 0.34 & 56.72 & 5 \\
20.518 & 0.01 & 1.49 & 6 \\
102.592 & 0.04 & 7.46 & 7 \\
20.518 & 0.01 & 1.49 & 8 \\
---- & ------- & \\
---- & \multicolumn{2}{l}{------- } \\
Area [ha] & \%Microb. \%Sub-b. N.HRUS
\end{tabular}


Uso do solo

Pastagem

$1.441 .669 \quad 0.63$

21.04

Cana-de-açúcar

$3.531 .045 \quad 1.54$

51.52

Mata

Cerrado

Reflorestamento

Agricultura Genérica

$355.194 \quad 0.16$

5.18

$689.494 \quad 0.30$

10.06

$\begin{array}{lll}167.150 & 0.07 & 2.44\end{array}$

$334.300 \quad 0.15 \quad 4.88$

Laranja

$334.300 \quad 0.15$

4.88

Solo

Gleissolo

Latossolo vermelho eutroférrico

$125.363 \quad 0.05$

$814.856 \quad 0.36$

1.83

Neossolo Quartzarênico

Latossolo vermelho mesoférrico

$2.632 .613 \quad 1.15$

11.89

1.89
613

$3.280 .320 \quad 1.43 \quad 47.87$

HRUS:

356 Pastagem/Latossolo vermelho eutroférrico

357 Pastagem/Latossolo vermelho mesoférrico

358 Pastagem/Neossolo Quartzarênico

Cana-de-acúcar/Latossolo vermelho

359 eutroférrico

Cana-de-açúcar/Latossolo vermelho

360 mesoférriço

361 Cana-de-açúcar/Neossolo Quartzarênico

362 Mata/Gleissolo

363 Mata/Latossolo vermelho eutroférrico

364 Mata/Latossolo vermelho mesoférrico

365 Mata/Neossolo Quartzarênico

366 Cerrado/Gleissolo

367 Cerrado/Latossolo vermelho eutroférrico

368 Cerrado/Latossolo vermelho mesoférrico

369 Cerrado/Neossolo Quartzarênico Reflorestamento/Latossolo vermelho

370 eutroférrico

Reflorestamento/Latossolo vermelho

371 mesoférrico

372 Reflorestamento/Neossolo Quartzarênico

373 Agricultura Genérica/Gleissolo

Agricultura Genérica/Latossolo vermelho

374 mesoférrico

Agricultura Genérica/Neossolo

375 Quartzarênico

376 Laranja/Gleissolo

377 Laranja/Latossolo vermelho eutroférrico

378 Laranja/Latossolo vermelho mesoférrico

379 Laranja/Neossolo Quartzarênico

$146.256 \quad 0.06$

$2.13 \quad 1$

$376.088 \quad 0.16$

5.492

$919.325 \quad 0.40$

$13.41 \quad 3$

$313.406 \quad 0.14$

$4.57 \quad 4$

$2.005 .801 \quad 0.88$

$29.27 \quad 5$

$1.211 .838 \quad 0.53$

$17.68 \quad 6$

$20.894 \quad 0.01$

$0.30 \quad 7$

$\begin{array}{llll}125.363 & 0.05 & 1.83 & 8\end{array}$

$\begin{array}{llll}167.150 & 0.07 & 2.44 & 9\end{array}$

$\begin{array}{llll}41.788 & 0.02 & 0.61 & 10\end{array}$

$\begin{array}{llll}20.894 & 0.01 & 0.30 & 11\end{array}$

$\begin{array}{llll}83.575 & 0.04 & 1.22 & 12\end{array}$

$\begin{array}{llll}334.300 & 0.15 & 4.88 & 13\end{array}$

$\begin{array}{llll}250.725 & 0.11 & 3.66 & 14\end{array}$

$\begin{array}{llll}104.469 & 0.05 & 1.52 \quad 15\end{array}$

$\begin{array}{llll}41.788 & 0.02 & 0.61 & 16\end{array}$

$\begin{array}{llll}20.894 & 0.01 & 0.30 & 17\end{array}$

$\begin{array}{llll}62.681 & 0.03 & 0.91 \quad 18\end{array}$

$\begin{array}{llll}188.044 & 0.08 & 2.74 \quad 19\end{array}$

$\begin{array}{llll}83.575 & 0.04 & 1.22 & 20\end{array}$

$\begin{array}{llll}20.894 & 0.01 & 0.30 & 21\end{array}$

$\begin{array}{llll}41.788 & 0.02 & 0.61 & 22\end{array}$

$\begin{array}{llll}167.150 & 0.07 & 2.44 & 23\end{array}$

$\begin{array}{llll}104.469 & 0.05 & 1.52 & 24\end{array}$

--.----

Area [ha] \%Microb. \%Sub-b. N.HRUs

Sub-bacia 23

$1.231 .105 \quad 0.54$

Uso do solo

Cana-de-açúcar

Mata

Cerrado

Reflorestamento

Agricu7tura Genérica

Laranja

$\begin{array}{rrr}20.518 & 0.01 & 1.67 \\ 389.850 & 0.17 & 31.67 \\ 41.037 & 0.02 & 3.33 \\ 225.703 & 0.10 & 18.33 \\ 430.887 & 0.19 & 35.00 \\ 123.111 & 0.05 & 10.00\end{array}$

Solo

Gleissolo

Latossolo vermelho eutroférrico

Neossolo Quartzarênico

$\begin{array}{rrr}225.703 & 0.10 & 18.33 \\ 61.555 & 0.03 & 5.00 \\ 943.847 & 0.41 & 76.67\end{array}$

HRUS :

380 Cana-de-açúcar/Neossolo Quartzarênico

381 Mata/Gleissolo

382 Mata/Latossolo vermelho eutroférrico

$\begin{array}{llll}20.518 & 0.01 & 1.67 & 1 \\ 82.074 & 0.04 & 6.67 & 2 \\ 61.555 & 0.03 & 5.00 & 3\end{array}$




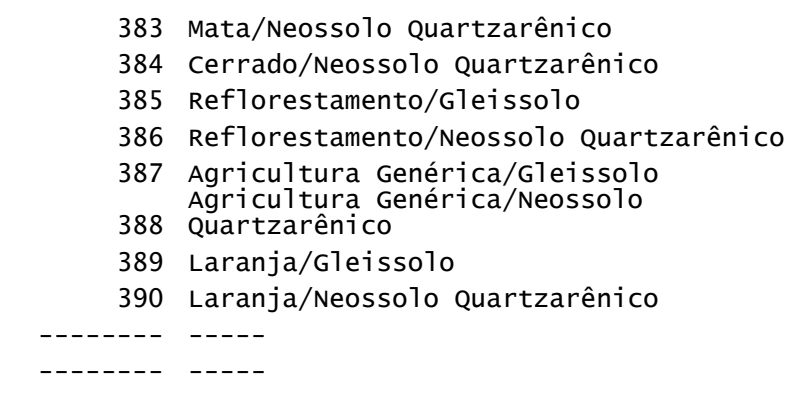

Sub-bacia 24

Uso do solo

Pastagem

Cana-de-açúcar

Mata

Cerrado

Reflorestamento

Agricultura Genérica

Laranja

Solo

Gleissolo

Latossolo vermelho eutroférrico

Neossolo Quartzarênico

Latossolo vermelho mesoférrico

HRUS:

391 Pastagem/Latossolo vermelho eutroférrico

392 Pastagem/Latossolo vermelho mesoférrico

393 Pastagem/Neossolo Quartzarênico

Cana-de-açúcar/Latossolo vermelho

394 eutroférrico

cana-de-açúcar/Latossolo vermelho

395 mesoférrico

396 Cana-de-açúcar/Neossolo Quartzarênico

$397 \mathrm{Mata} /$ Latossolo vermelho eutroférrico

398 Mata/Latossolo vermelho mesoférrico

399 Mata/Neossolo Quartzarênico

400 Cerrado/Latossolo vermelho eutroférrico

401 Cerrado/Latossolo verme1ho mesoférrico

402 Cerrado/Neossolo Quartzarênico

Reflorestamento/Latossolo vermelho

403 eutroférrico

404 Reflorestamento/Neossolo Quartzarênico

405 Agricultura Genérica/Gleissolo

Agricultura Genérica/Latossolo vermelho

406 eutroférrico Agricultura Genérica/Latossolo vermelho

407 mesoférrico

Agricultura Genérica/Neossolo

408 Quartzarênico

409 Laranja/Latossolo vermelho eutroférrico

410 Laranja/Latossolo vermelho mesoférrico

411 Laranja/Neossolo Quartzarênico

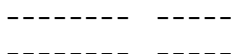

Sub-bacia 25

Uso do solo

Pastagem

Cana-de-açúcar

Mata

Cerrado

Reflorestamento

$\begin{array}{rlrr}246.221 & 0.11 & 20.00 & 4 \\ 41.037 & 0.02 & 3.33 & 5 \\ 61.555 & 0.03 & 5.00 & 6 \\ 164.147 & 0.07 & 13.33 & 7 \\ 61.555 & 0.03 & 5.00 & 8 \\ 369.332 & 0.16 & 30.00 & 9 \\ 20.518 & 0.01 & 1.67 & 10 \\ 102.592 & 0.04 & 8.33 & 11\end{array}$

Area [ha] \%Microb. \%Sub-b. N.HRUs

$5.457 .899 \quad 2.39$

$\begin{array}{rrr}779.700 & 0.34 & 14.29 \\ .318 .581 & 1.01 & 42.48 \\ 574.516 & 0.25 & 10.53 \\ 697.626 & 0.30 & 12.78 \\ 143.629 & 0.06 & 2.63 \\ 184.666 & 0.08 & 3.38 \\ 759.181 & 0.33 & 13.91\end{array}$

$\begin{array}{lll}41.037 & 0.02 & 0.75\end{array}$

$\begin{array}{lll}1.538 .881 & 0.67 & 28.20\end{array}$

$2.811 .023 \quad 1.23 \quad 51.50$

$\begin{array}{lll}1.066 .958 & 0.47 \quad 19.55\end{array}$

$\begin{array}{rlrr}143.629 & 0.06 & 2.63 & 1 \\ 123.111 & 0.05 & 2.26 & 2 \\ 512.960 & 0.22 & 9.40 & 3 \\ 287.258 & 0.13 & 5.26 & 4 \\ 779.700 & 0.34 & 14.29 & 5 \\ 1.251 .623 & 0.55 & 22.93 & 6 \\ 266.739 & 0.12 & 4.89 & 7 \\ 20.518 & 0.01 & 0.38 & 8 \\ 287.258 & 0.13 & 5.26 & 9 \\ 471.924 & 0.21 & 8.65 & 10 \\ 61.555 & 0.03 & 1.13 & 11 \\ 164.147 & 0.07 & 3.01 & 12 \\ 20.518 & 0.01 & 0.38 & 13 \\ 123.111 & 0.05 & 2.26 & 14 \\ 41.037 & 0.02 & 0.75 & 15 \\ 20.518 & 0.01 & 0.38 & 16 \\ 41.037 & 0.02 & 0.75 & 17 \\ 82.074 & 0.04 & 1.50 & 18 \\ 328.295 & 0.14 & 6.02 & 19 \\ 41.037 & 0.02 & 0.75 & 20 \\ 389.850 & 0.17 & 7.14 & 21 \\ ---- & ------- & & \\ ---- & ------- & & \end{array}$

Area [ha] \%Microb. \%Sub-b. N.HRUs

$7.817 .518 \quad 3.42$ 
Agricultura Genérica

Laranja

Solo

Neossolo Litólico

Latossolo vermelho eutroférrico

Neossolo Quartzarênico

Latossolo vermelho mesoférrico

HRUS:

412 Pastagem/Latossolo vermelho eutroférrico

413 Pastagem/Latossolo vermelho mesoférrico

414 Cana-de-açúcar/Neossolo Litólico cana-de-açúcar/Latossolo vermelho

415 eutroférrico

Cana-de-açúcar/Latossolo verme1ho

416 mesoférriço

417 Cana-de-açúcar/Neossolo Quartzarênico

418 Mata/Neossolo Litólico

419 Mata/Latossolo vermelho eutroférrico

$420 \mathrm{Mata} /$ Latossolo vermelho mesoférrico

421 Mata/Neossolo Quartzarênico

422 Cerrado/Latossolo vermelho eutroférrico

423 Cerrado/Latossolo vermelho mesoférrico

424 Cerrado/Neossolo Quartzarênico

425 Reflorestamento/Neossolo Litólico Reflorestamento/Latossolo vermelho

426 eutroférrico

Reflorestamento/Latossolo vermelho

427 mesoférrico

Agricultura Genérica/Neossolo

428 Quartzarênico

429 Laranja/Neossolo Quartzarênico

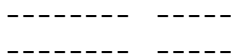

Sub-bacia 26

Uso do solo

Pastagem

Cana-de-açúcar

Mata

Cerrado

Agricultura Genérica

Laranja

Solo

Gleissolo

Neossolo Litólico

Latossolo vermelho eutroférrico

Neossolo Quartzarênico

Latossolo vermelho mesoférrico

HRUS :

430 Pastagem/Neossolo Litólico

431 Pastagem/Latossolo vermelho eutroférrico

432 Pastagem/Latossolo vermelho mesoférrico

433 Pastagem/Neossolo Quartzarênico

434 Cana-de-açúcar/Neossolo Litólico

Cana-de-ać́car/Latossolo vermelho

435 eutroférriçco

436 Cana-de-açúcar/Neossolo Quartzarênico

437 Mata/Gleissolo

438 Mata/Neossolo Litólico

439 Mata/Latossolo vermelho eutroférrico

440 Mata/Latossolo vermelho mesoférrico

441 Mata/Neossolo Quartzarênico

442 Cerrado/Gleissolo

443 Cerrado/Neossolo Litólico
$25.382 \quad 0.01$

$25.382 \quad 0.01$

0.32

0.32

$\begin{array}{lll}329.960 & 0.14 & 4.22\end{array}$

$2.335 .103 \quad 1.02 \quad 29.87$

$4.162 .575 \quad 1.82 \quad 53.25$

$\begin{array}{lll}989.881 & 0.43 \quad 12.66\end{array}$

$203.052 \quad 0.09$

$25.382 \quad 0.01$

$2.60 \quad 1$

$101.526 \quad 0.04$

$0.32 \quad 2$

$1.700 .564 \quad 0.74$

$21.75 \quad 4$

$685.302 \quad 0.30$

$8.77 \quad 5$

$\begin{array}{ll}1.928 .998 & 0.84\end{array}$

$\begin{array}{lll}177.671 & 0.08\end{array}$

$24.68 \quad 6$

$1599.038 \quad 0.70$
-59

$\begin{array}{rrrr}101.526 & 0.04 & 1.30 & 11\end{array}$

$\begin{array}{llll}76.145 & 0.03 & 0.97 & 12\end{array}$

$\begin{array}{llll}583.776 & 0.26 & 7.47 & 13\end{array}$

$\begin{array}{llll}50.763 & 0.02 & 0.65 & 14\end{array}$

$\begin{array}{llll}50.763 & 0.02 & 0.65 \quad 15\end{array}$

$\begin{array}{llll}50.763 & 0.02 & 0.65 & 16\end{array}$

$\begin{array}{llll}25.382 & 0.01 & 0.32 & 17\end{array}$

$\begin{array}{llll}25.382 & 0.01 & 0.32 & 18\end{array}$

Area [ha] \%Microb. \%Sub-b. N.HRUS

$5.786 .195 \quad 2.53$

$\begin{array}{lll}451.405 & 0.20 & 7.80\end{array}$

$\begin{array}{lll}779.700 & 0.34 & 13.48\end{array}$

$2.503 .247 \quad 1.09 \quad 43.26$

$\begin{array}{lll}943.847 & 0.41 & 16.31\end{array}$

$\begin{array}{lll}820.737 & 0.36 & 14.18\end{array}$

$\begin{array}{llll}287.258 & 0.13 & 4.96\end{array}$

$\begin{array}{lll}246.221 & 0.11 & 4.26\end{array}$

$\begin{array}{lll}512.961 & 0.22 & 8.87\end{array}$

$\begin{array}{lll}984.884 & 0.43 \quad 17.02\end{array}$

$3.344 .503 \quad 1.46 \quad 57.80$

$\begin{array}{lll}697.626 & 0.30 & 12.06\end{array}$

$\begin{array}{llll}102.592 & 0.04 & 1.77 & 1\end{array}$

$\begin{array}{llll}287.258 & 0.13 & 4.96 & 2\end{array}$

$\begin{array}{llll}41.037 & 0.02 & 0.71 & 3\end{array}$

$\begin{array}{llll}20.518 & 0.01 & 0.35 & 4\end{array}$

$\begin{array}{llll}82.074 & 0.04 & 1.42 & 5\end{array}$

$\begin{array}{llll}164.147 & 0.07 & 2.84 & 6\end{array}$

$\begin{array}{llll}533.479 & 0.23 & 9.22 & 7\end{array}$

$\begin{array}{llll}123.111 & 0.05 & 2.13 & 8\end{array}$

$\begin{array}{llll}82.074 & 0.04 & 1.42 & 9\end{array}$

$\begin{array}{llll}123.111 & 0.05 & 2.13 & 10\end{array}$

$\begin{array}{llll}184.666 & 0.08 & 3.19 & 11\end{array}$

$\begin{array}{llll}1.990 .287 & 0.87 & 34.40 & 12\end{array}$

$\begin{array}{llll}102.592 & 0.04 & 1.77 & 13\end{array}$

$\begin{array}{llll}61.555 & 0.03 & 1.06 & 14\end{array}$ 


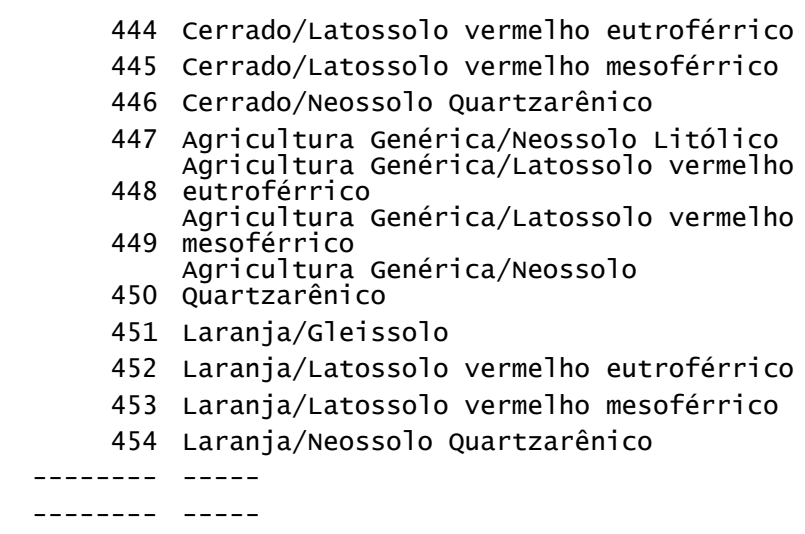

Sub-bacia 27

Uso do solo

\section{Pastagem}

Cana-de-açúcar

Mata

Cerrado

Agricultura Genérica

Laranja

Solo

Latossolo Amare1o

Neossolo Litólico

Latossolo vermelho eutroférrico

Latossolo vermelho mesoférrico

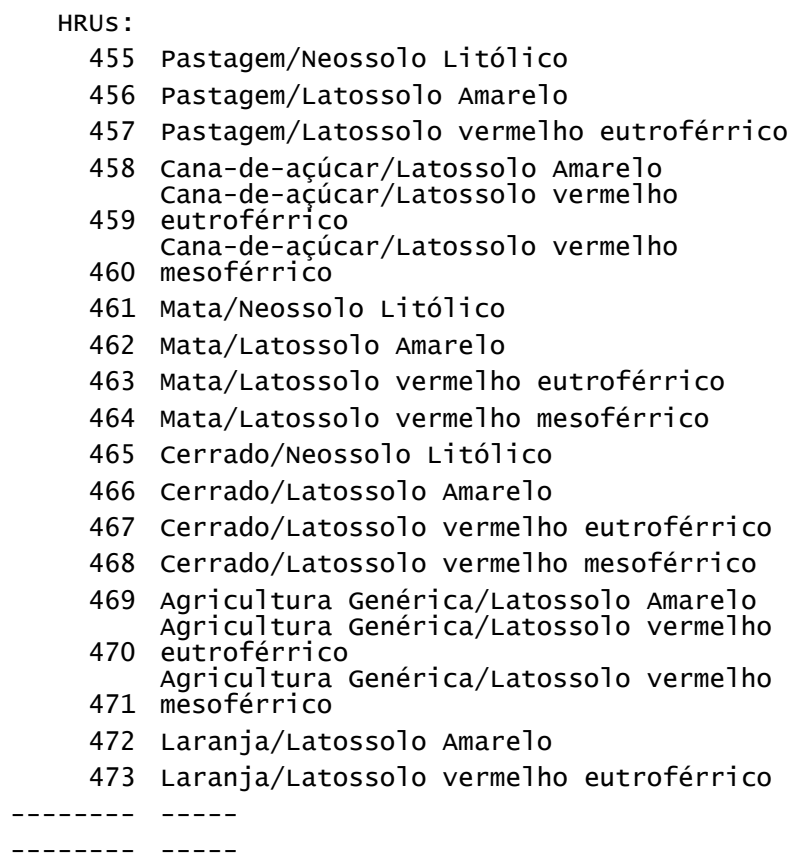

Uso do solo

Pastagem

Cana-de-açúcar

Mata

Cerrado

Reflorestamento

$\begin{array}{rlll}143.629 & 0.06 & 2.48 & 15 \\ 123.111 & 0.05 & 2.13 & 16 \\ 512.961 & 0.22 & 8.87 & 17 \\ 184.666 & 0.08 & 3.19 & 18 \\ 225.703 & 0.10 & 3.90 & 19 \\ 328.295 & 0.14 & 5.67 & 20 \\ 82.074 & 0.04 & 1.42 & 21 \\ 20.518 & 0.01 & 0.35 & 22 \\ 41.037 & 0.02 & 0.71 & 23 \\ 20.518 & 0.01 & 0.35 & 24 \\ 205.184 & 0.09 & 3.55 & 25 \\ --- & -------- & & \end{array}$

Area [ha] \%Microb. \%Sub-b. N.HRUs

$7.530 .260 \quad 3.29$

$\begin{array}{rrr}2.154 .434 & 0.94 & 28.61 \\ 1.333 .697 & 0.58 & 17.71 \\ 1.107 .995 & 0.48 & 14.71 \\ 1.579 .918 & 0.69 & 20.98 \\ 861.774 & 0.38 & 11.44 \\ 492.442 & 0.22 & 6.54\end{array}$

$\begin{array}{rrr}4.842 .347 & 2.12 & 64.31 \\ 697.626 & 0.30 & 9.26 \\ 1.579 .918 & 0.69 & 20.98 \\ 410.368 & 0.18 & 5.45\end{array}$

$\begin{array}{rrrr}82.074 & 0.04 & 1.09 & 1\end{array}$

$\begin{array}{llll}1.477 .326 & 0.65 & 19.62 & 2\end{array}$

$\begin{array}{rrrr}595.034 & 0.26 & 7.90 & 3\end{array}$

$\begin{array}{llll}964.366 & 0.42 & 12.81 & 4\end{array}$

$\begin{array}{llll}266.739 & 0.12 \quad 3.54 \quad 5\end{array}$

$\begin{array}{llll}102.592 & 0.04 & 1.36 & 6\end{array}$

$\begin{array}{llll}266.739 & 0.12 & 3.54 & 7\end{array}$

$\begin{array}{llll}246.221 & 0.11 & 3.27 & 8\end{array}$

$\begin{array}{llll}389.850 & 0.17 & 5.18 & 9\end{array}$

$\begin{array}{llll}205.184 & 0.09 & 2.72 & 10\end{array}$

$\begin{array}{rrrr}348.813 & 0.15 & 4.63 & 11\end{array}$

$\begin{array}{llll}923.329 & 0.40 & 12.26 & 12\end{array}$

$\begin{array}{llll}225.703 & 0.10 & 3.00 & 13\end{array}$

$\begin{array}{llll}82.074 & 0.04 & 1.09 & 14\end{array}$

$800.218 \quad 0.35 \quad 10.63 \quad 15$

$\begin{array}{llll}41.037 & 0.02 & 0.54 \quad 16\end{array}$

$\begin{array}{llll}20.518 & 0.01 & 0.27 & 17\end{array}$

$\begin{array}{lllll}430.887 & 0.19 & 5.72 & 18\end{array}$

$\begin{array}{llll}61.555 & 0.03 & 0.82 & 19\end{array}$

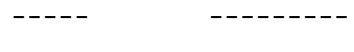

Area [ha] \%Microb. \%Sub-b. N.HRUs

$11.285 .131 \quad 4.93$

$\begin{array}{rrr}1.249 .198 & 0.55 & 11.07 \\ 1.376 .235 & 0.60 & 12.20 \\ 486.976 & 0.21 & 4.32 \\ 868.087 & 0.38 & 7.69 \\ 317.593 & 0.14 & 2.81\end{array}$


Agricultura Genérica

Laranja

Solo

Latossolo Amarelo

Latossolo vermelho eutroférrico

Neossolo Quartzarênico

Latossolo vermelho mesoférrico

HRUS:

474 Pastagem/Latossolo Amarelo

475 Pastagem/Latossolo vermelho eutroférrico

476 Pastagem/Latossolo vermelho mesoférrico

477 Pastagem/Neossolo Quartzarênico

478 Cana-de-açúcar/Latossolo Amarelo

Cana-de-acúcar/Latossolo vermelho

479 eutroférrico

480 Cana-de-açúcar/Neossolo Quartzarênico

481 Mata/Latossolo Amarelo

482 Mata/Latossolo vermelho mesoférrico

483 Mata/Neossolo Quartzarênico

484 Cerrado/Latossolo Amarelo

485 Cerrado/Latossolo vermelho eutroférrico

486 Cerrado/Latossolo vermelho mesoférrico

487 Cerrado/Neossolo Quartzarênico

488 Reflorestamento/Latossolo Amare1o Reflorestamento/Latossolo vermelho

489 mesoférrico

490 Reflorestamento/Neossolo Quartzarênico

491 Agricultura Genérica/Latossolo Amarelo Agricultura Genérica/Neossolo

492 Quartzarênico

493 Laranja/Latossolo Amarelo

494 Laranja/Latossolo vermelho mesoférrico

495 Laranja/Neossolo Quartzarênico

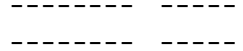

Sub-bacia 29

Uso do solo

Pastagem

Cana-de-açúcar

Mata

Cerrado

Reflorestamento

Agricultura Genérica

Solo

Latossolo Amarelo

Neossolo Litólico

Latossolo vermelho eutroférrico

Latossolo vermelho mesoférrico

HRUS:

496 Pastagem/Neossolo Litólico

497 Pastagem/Latossolo Amare1o

498 Pastagem/Latossolo verme1ho eutroférrico

499 Pastagem/Latossolo vermelho mesoférrico

500 Cana-de-açúcar/Neossolo Litólico

501 Cana-de-açúcar/Latossolo Amarelo Cana-de-acúcar/Latossolo vermelho

502 eutroférrico

Cana-de-açúcar/Latossolo vermelho

503 mesoférrico

504 Mata/Neossolo Litólico

505 Mata/Latossolo Amarelo

$506 \mathrm{Mata} /$ Latossolo vermelho eutroférrico $\begin{array}{lll}211.729 & 0.09 & 1.88\end{array}$

$6.775 .313 \quad 2.96 \quad 60.04$

$\begin{array}{rrr}7.728 .092 & 3.38 & 68.48 \\ 529.321 & 0.23 & 4.69 \\ 2.180 .804 & 0.95 & 19.32 \\ 846.914 & 0.37 & 7.50\end{array}$

$614.013 \quad 0.27$

$254.074 \quad 0.11$

$21.173 \quad 0.01$

$359.939 \quad 0.16$

$381.111 \quad 0.17$

$232.901 \quad 0.10$

$\begin{array}{lll}762.223 & 0.33\end{array}$

$338.766 \quad 0.15$

$63.519 \quad 0.03$

$84.691 \quad 0.04$

$635.186 \quad 0.28$

$\begin{array}{ll}42.346 & 0.02\end{array}$

$105.864 \quad 0.05$

$\begin{array}{ll}84.691 & 0.04\end{array}$

$254.074 \quad 0.11$

$21.173 \quad 0.01$

$42.346 \quad 0.02$

$105.864 \quad 0.05$

$105.864 \quad 0.05$

$\begin{array}{ll}5.399 .078 & 2.36\end{array}$

$\begin{array}{ll}635.186 & 0.28\end{array}$

$\begin{array}{lll}741.050 & 0.32\end{array}$

$5.44 \quad 1$

$2.25 \quad 2$

0.193

3.194

$3.38 \quad 5$

$2.06 \quad 6$

$6.75 \quad 7$

$3.00 \quad 8$

$0.56 \quad 9$

$0.75 \quad 10$

$5.63 \quad 11$

$0.38 \quad 12$

$0.94 \quad 13$

$0.75 \quad 14$

$2.25 \quad 15$

$0.19 \quad 16$

$0.38 \quad 17$

$0.94 \quad 18$

$0.94 \quad 19$

$47.84 \quad 20$

$5.63 \quad 21$

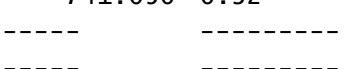

Area [ha] \%Microb. \%Sub-b. N.HRUs

$8.822 .921 \quad 3.86$

$\begin{array}{lll}2.806 .327 & 1.23 & 31.81\end{array}$

$\begin{array}{lll}1.169 .303 & 0.51 & 13.25\end{array}$

$\begin{array}{lll}1.360 .643 & 0.59 & 15.42\end{array}$

$3.189 .008 \quad 1.39 \quad 36.14$

$\begin{array}{lll}233.861 & 0.10 & 2.65\end{array}$

$\begin{array}{lll}63.780 & 0.03 & 0.72\end{array}$

$\begin{array}{lll}4.974 .852 & 2.17 & 56.39\end{array}$

$2.359 .866 \quad 1.03 \quad 26.75$

$\begin{array}{rrr}127.560 & 0.06 & 1.45\end{array}$

$1.360 .643 \quad 0.59 \quad 15.42$

$\begin{array}{llll}255.121 & 0.11 & 2.89 & 1\end{array}$

$\begin{array}{rrrr}2.211 .045 & 0.97 & 25.06 & 2\end{array}$

$\begin{array}{llll}42.520 & 0.02 & 0.48 & 3\end{array}$

$\begin{array}{llll}297.641 & 0.13 & 3.37 & 4\end{array}$

$\begin{array}{llll}85.040 & 0.04 & 0.96 & 5\end{array}$

$\begin{array}{llll}1.041 .742 & 0.46 & 11.81 & 6\end{array}$

$\begin{array}{llll}21.260 & 0.01 & 0.24 & 7\end{array}$

$\begin{array}{lllll}21.260 & 0.01 & 0.24 & 8\end{array}$

$\begin{array}{llll}637.802 & 0.28 & 7.23 & 9\end{array}$

$\begin{array}{llll}488.981 & 0.21 & 5.54 & 10\end{array}$

$\begin{array}{llll}21.260 & 0.01 & 0.24 & 11\end{array}$ 


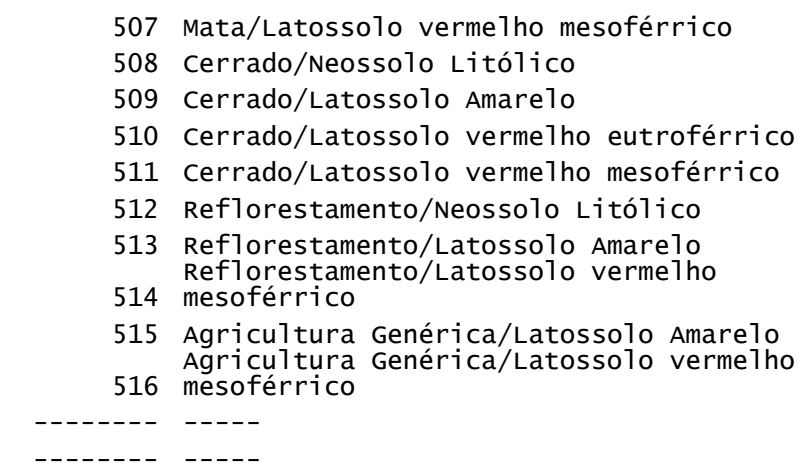

Sub-bacia 30

Uso do solo

Pastagem

Água

Cana-de-açúcar

Mata

Cerrado

Reflorestamento

Agricultura Genérica

Laranja

Solo

Latossolo Amarelo

Neossolo Litólico

Latossolo vermelho eutroférrico

HRUS:

517 Pastagem/Neossolo Litólico

518 Pastagem/Latossolo Amarelo

519 Pastagem/Latossolo vermelho eutroférrico

520 Água/Latossolo Amarelo

521 Cana-de-açúcar/Neossolo Litólico

522 Cana-de-açúcar/Latossolo Amarelo

Cana-de-acúcar/Latossolo vermelho

523 eutroférrico

524 Mata/Neossolo Litólico

525 Mata/Latossolo Amarelo

526 Cerrado/Neossolo Litólico

527 Cerrado/Latossolo Amarelo

528 Cerrado/Latossolo vermelho eutroférrico

529 Reflorestamento/Neossolo Litólico

530 Reflorestamento/Latossolo Amarelo

531 Agricultura Genérica/Latossolo Amarelo

532 Laranja/Latossolo Amarelo

Sub-bacia 31

Uso do solo

Pastagem

Cana-de-açúcar

Mata

Cerrado

Laranja

Solo

Gleissolo

Latossolo Amarelo

Argissolo

$\begin{array}{rlrr}212.601 & 0.09 & 2.41 & 12 \\ 1.211 .823 & 0.53 & 13.73 & 13 \\ 1.190 .563 & 0.52 & 13.49 & 14 \\ 42.520 & 0.02 & 0.48 & 15 \\ 744.102 & 0.33 & 8.43 & 16 \\ 170.080 & 0.07 & 1.93 & 17 \\ 21.260 & 0.01 & 0.24 & 18 \\ 42.520 & 0.02 & 0.48 & 19 \\ 21.260 & 0.01 & 0.24 & 20 \\ 42.520 & 0.02 & 0.48 & 21 \\ --- & ------- & \end{array}$

Area [ha] \%Microb. \%Sub-b. N.HRUs

$11.141 .502 \quad 4.87$

$\begin{array}{rrr}2.202 .639 & 0.96 & 19.77 \\ 21.385 & 0.01 & 0.19 \\ 2.031 .560 & 0.89 & 18.23 \\ 684.315 & 0.30 & 6.14 \\ 1.304 .475 & 0.57 & 11.71 \\ 299.388 & 0.13 & 2.69 \\ 85.539 & 0.04 & 0.77 \\ 4.512 .201 & 1.97 & 40.50\end{array}$

$9.623 .178 \quad 4.21 \quad 86.37$

$\begin{array}{lll}1.005 .088 & 0.44 & 9.02\end{array}$

$\begin{array}{lll}513.236 & 0.22 & 4.61\end{array}$

$\begin{array}{llll}21.385 & 0.01 & 0.19 & 1\end{array}$

$\begin{array}{llll}2.159 .869 & 0.94 & 19.39 & 2\end{array}$

$\begin{array}{llll}21.385 & 0.01 & 0.19 & 3\end{array}$

$\begin{array}{llll}21.385 & 0.01 & 0.19 & 4\end{array}$

$\begin{array}{llll}192.464 & 0.08 & 1.73 & 5\end{array}$

$\begin{array}{llll}1.368 .630 & 0.60 & 12.28 & 6\end{array}$

$\begin{array}{llll}470.466 & 0.21 & 4.22 & 7\end{array}$

$\begin{array}{llll}278.003 & 0.12 & 2.50 & 8\end{array}$

$\begin{array}{llll}406.312 & 0.18 & 3.65 & 9\end{array}$

$\begin{array}{llll}384.927 & 0.17 & 3.45 & 10\end{array}$

$\begin{array}{llll}898.163 & 0.39 & 8.06 & 11\end{array}$

$\begin{array}{llll}21.385 & 0.01 & 0.19 & 12\end{array}$

$\begin{array}{llll}128.309 & 0.06 & 1.15 & 13\end{array}$

$\begin{array}{llll}171.079 & 0.07 & 1.54 & 14\end{array}$

$\begin{array}{llll}85.539 & 0.04 & 0.77 & 15\end{array}$

$\begin{array}{llll}4.512 .201 & 1.97 & 40.50 & 16\end{array}$

----- -------

----- --------

$225.703 \quad 0.10$

$\begin{array}{rrr}20.518 & 0.01 & 9.09 \\ 143.629 & 0.06 & 63.64 \\ 20.518 & 0.01 & 9.09 \\ 20.518 & 0.01 & 9.09 \\ 20.518 & 0.01 & 9.09\end{array}$

$\begin{array}{lll}61.555 & 0.03 \quad 27.27\end{array}$

$\begin{array}{lll}102.592 & 0.04 & 45.45\end{array}$

$\begin{array}{lll}61.555 & 0.03 \quad 27.27\end{array}$ 


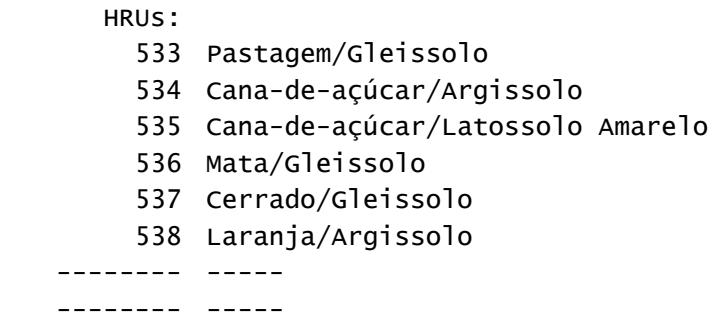

Sub-bacia 32

Uso do solo

Pastagem

Cana-de-açúcar

Mata

Cerrado

Laranja

Solo

Latossolo Amarelo

Argissolo

HRUS:

539 Pastagem/Latossolo Amare1o

540 Cana-de-açúcar/Argissolo

541 Cana-de-açúcar/Latossolo Amarelo

542 Mata/Latossolo Amarelo

543 Cerrado/Argissolo

544 Cerrado/Latossolo Amarelo

545 Laranja/Argissolo

546 Laranja/Latossolo Amarelo

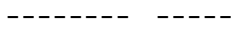

Sub-bacia 33

Uso do solo

Cerrado

Solo

Argissolo

HRUS :

547 Cerrado/Argissolo

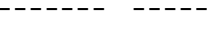

Sub-bacia 34

Uso do solo

Pastagem

Cana-de-açúcar

Mata

Cerrado

Agricultura Genérica

Laranja

Solo

Gleissolo

Latossolo Amarelo

Latossolo vermelho eutroférrico

$\begin{array}{rlrr}20.518 & 0.01 & 9.09 & 1 \\ 41.037 & 0.02 & 18.18 & 2 \\ 102.592 & 0.04 & 45.45 & 3 \\ 20.518 & 0.01 & 9.09 & 4 \\ 20.518 & 0.01 & 9.09 & 5 \\ 20.518 & 0.01 & 9.09 & 6 \\ --- & ------ & \end{array}$

Area [ha] \%Microb. \%Sub-b. N.HRUs

$1.374 .734 \quad 0.60$

$\begin{array}{lll}21.150 & 0.01 & 1.54\end{array}$

$\begin{array}{lll}507.594 & 0.22 & 36.92\end{array}$

$21.150 \quad 0.01 \quad 1.54$

$\begin{array}{lll}169.198 & 0.07 & 12.31\end{array}$

$\begin{array}{lll}655.642 & 0.29 & 47.69\end{array}$

$\begin{array}{lll}1.290 .135 & 0.56 & 93.85\end{array}$

$84.599 \quad 0.04 \quad 6.15$

$\begin{array}{llll}21.150 & 0.01 & 1.54 & 1\end{array}$

$\begin{array}{llll}21.150 & 0.01 & 1.54 & 2\end{array}$

$\begin{array}{llll}486.444 & 0.21 & 35.38 & 3\end{array}$

$21.150 \quad 0.01 \quad 1.54 \quad 4$

$\begin{array}{llll}21.150 & 0.01 & 1.54 & 5\end{array}$

$\begin{array}{llll}148.048 & 0.06 & 10.77 & 6\end{array}$

$\begin{array}{lllll}42.300 & 0.02 & 3.08 & 7\end{array}$

$\begin{array}{llll}613.343 & 0.27 & 44.62 & 8\end{array}$

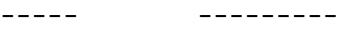

Area [ha] \%Microb. \%Sub-b. N.HRUs

$20.518 \quad 0.01$

$20.518 \quad 0.01 \quad 100.00$

$20.518 \quad 0.01 \quad 100.00$

$\begin{array}{llll}20.518 & 0.01 & 100.00 & 1\end{array}$

Area [ha] \%Microb. \%Sub-b. N.HRUs

$4.452 .497 \quad 1.95$

$\begin{array}{rrr}964.366 & 0.42 & 21.66 \\ 800.218 & 0.35 & 17.97 \\ 369.332 & 0.16 & 8.29 \\ 471.924 & 0.21 & 10.60 \\ 20.518 & 0.01 & 0.46 \\ .826 .139 & 0.80 & 41.01\end{array}$

$\begin{array}{lll}615.553 & 0.27 & 13.82\end{array}$

$2.811 .023 \quad 1.23 \quad 63.13$

$\begin{array}{lll}41.037 & 0.02 & 0.92\end{array}$ 


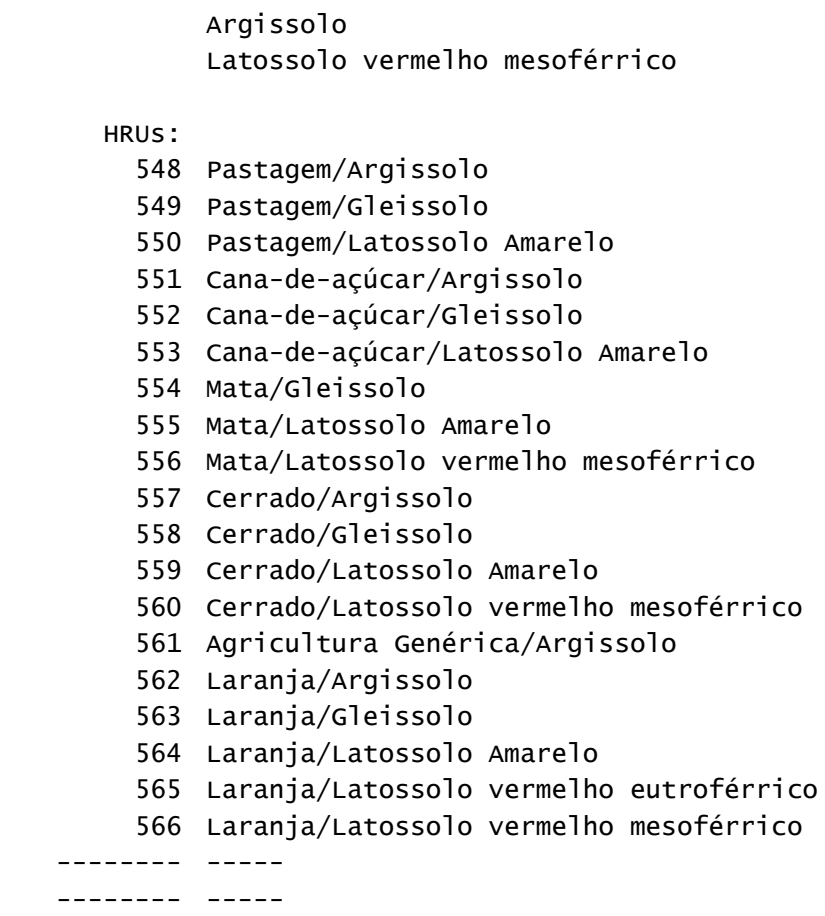

Sub-bacia 35

Uso do solo

Agricultura Genérica

Laranja

Solo

Latossolo Amare1o

HRUS:

567 Agricultura Genérica/Latossolo Amarelo

568 Laranja/Latossolo Amare1o

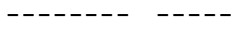

Sub-bacia 36

Uso do solo

Pastagem

Cana-de-açúcar

Mata

Cerrado

Reflorestamento

Agricultura Genérica

Laranja

Solo

Latossolo Amare1o

Argissolo

Latossolo vermelho eutroférrico

HRUS :

569 Pastagem/Latossolo Amarelo

570 Pastagem/Latossolo vermelho eutroférrico

571 Cana-de-açúcar/Argissolo

572 Cana-de-aćúcar/Latossolo Amarelo

Cana-de-acúcar/Latossolo vermelho

573 eutroférrico

574 Mata/Latossolo Amarelo $\begin{array}{lll}738.663 & 0.32 & 16.59\end{array}$

$\begin{array}{lll}246.221 & 0.11 & 5.53\end{array}$

$\begin{array}{llll}246.221 & 0.11 & 5.53 & 1\end{array}$

$\begin{array}{llll}246.221 & 0.11 & 5.53 & 2\end{array}$

$\begin{array}{llll}471.924 & 0.21 & 10.60 & 3\end{array}$

$\begin{array}{llll}61.555 & 0.03 & 1.38 & 4\end{array}$

$\begin{array}{llll}20.518 & 0.01 & 0.46 & 5\end{array}$

$\begin{array}{llll}718.145 & 0.31 & 16.13 & 6\end{array}$

$\begin{array}{llll}61.555 & 0.03 & 1.38 & 7\end{array}$

$\begin{array}{llll}225.703 & 0.10 & 5.07 & 8\end{array}$

$\begin{array}{llll}82.074 & 0.04 & 1.84 & 9\end{array}$

$\begin{array}{llll}102.592 & 0.04 & 2.30 & 10\end{array}$

$\begin{array}{llll}82.074 & 0.04 & 1.84 & 11\end{array}$

$\begin{array}{llll}205.184 & 0.09 & 4.61 & 12\end{array}$

$\begin{array}{llll}82.074 & 0.04 & 1.84 & 13\end{array}$

$\begin{array}{llll}20.518 & 0.01 & 0.46 \quad 14\end{array}$

$\begin{array}{llll}307.776 & 0.13 & 6.91 & 15\end{array}$

$\begin{array}{llll}205.184 & 0.09 & 4.61 & 16\end{array}$

$\begin{array}{llll}1.190 .068 & 0.52 & 26.73 & 17\end{array}$

$\begin{array}{llll}41.037 & 0.02 & 0.92 & 18\end{array}$

$\begin{array}{llll}82.074 & 0.04 & 1.84 & 19\end{array}$

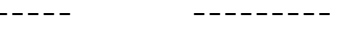

Area [ha] \%Microb. \%Sub-b. N.HRUs

$82.074 \quad 0.04$
$41.037 \quad 0.02$
50.00
$\begin{array}{lll}41.037 & 0.02\end{array}$
50.00

$82.074 \quad 0.04 \quad 100.00$

$\begin{array}{llll}41.037 & 0.02 & 50.00 & 1 \\ 41.037 & 0.02 & 50.00 & 2\end{array}$

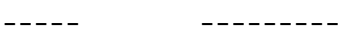

Area [ha] \%Microb. \%Sub-b. N.HRUS

$3.549 .687 \quad 1.55$

$\begin{array}{lll}574.516 & 0.25 & 16.18\end{array}$

$\begin{array}{lll}1.251 .624 & 0.55 & 35.26\end{array}$

$\begin{array}{lll}389.850 & 0.17 & 10.98\end{array}$

$\begin{array}{lll}615.553 & 0.27 & 17.34\end{array}$

$\begin{array}{lll}61.555 & 0.03 & 1.73\end{array}$

$\begin{array}{lll}20.518 & 0.01 & 0.58\end{array}$

$\begin{array}{lll}636.071 & 0.28 & 17.92\end{array}$

$\begin{array}{lll}1.025 .921 & 0.45 & 28.90\end{array}$

$\begin{array}{rrr}61.555 & 0.03 & 1.73\end{array}$

$2.462 .211 \quad 1.08 \quad 69.36$

$\begin{array}{rlrl}41.037 & 0.02 & 1.16 & 1 \\ 533.479 & 0.23 & 15.03 & 2 \\ 41.037 & 0.02 & 1.16 & 3 \\ 574.516 & 0.25 & 16.18 & 4 \\ 636.071 & 0.28 & 17.92 & 5 \\ 143.629 & 0.06 & 4.05 & 6\end{array}$




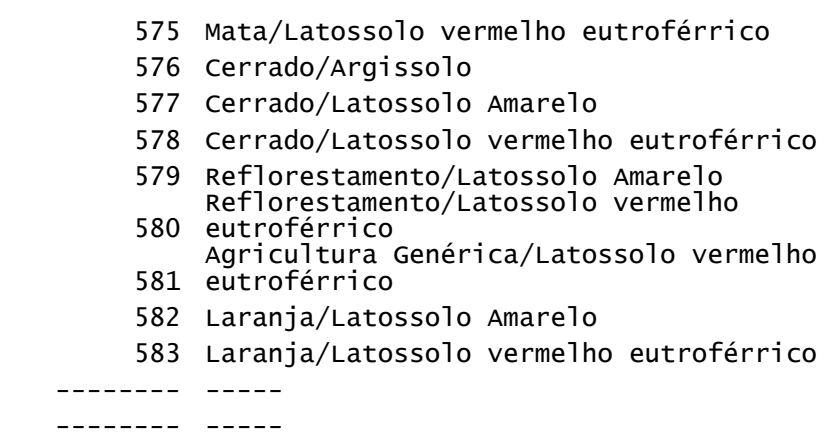

Sub-bacia 37

Uso do solo

Pastagem

Cana-de-açúcar

Cerrado

Laranja

Solo

Latossolo Amarelo

HRUS:

584 Pastagem/Latossolo Amarelo

585 Cana-de-açúcar/Latossolo Amare1o

586 Cerrado/Latossolo Amarelo

587 Laranja/Latossolo Amarelo

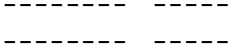

Sub-bacia 38

Uso do solo

Pastagem

Cana-de-açúcar

Cerrado

Agricultura Genérica

Laranja

Solo

Latossolo Amarelo

HRUS:

588 Pastagem/Latossolo Amarelo

589 Cana-de-açúcar/Latossolo Amarelo

590 Cerrado/Latossolo Amarelo

591 Agricultura Genérica/Latossolo Amarelo

592 Laranja/Latossolo Amarelo

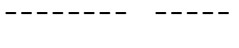

Sub-bacia 39

Uso do solo

Pastagem

Cana-de-açúcar

Cerrado

Área residencial

Agricultura Genérica

Laranja

$\begin{array}{rlrr}246.221 & 0.11 & 6.94 & 7 \\ 20.518 & 0.01 & 0.58 & 8 \\ 102.592 & 0.04 & 2.89 & 9 \\ 492.442 & 0.22 & 13.87 & 10 \\ 41.037 & 0.02 & 1.16 & 11 \\ 20.518 & 0.01 & 0.58 & 12 \\ 20.518 & 0.01 & 0.58 & 13 \\ 123.111 & 0.05 & 3.47 & 14 \\ 512.961 & 0.22 & 14.45 & 15 \\ - & ----- & & \end{array}$

Area [ha] \%Microb. \%Sub-b. N.HRUs

$1.272 .142 \quad 0.56$

$\begin{array}{rrr}410.368 & 0.18 & 32.26 \\ 471.924 & 0.21 & 37.10 \\ 61.555 & 0.03 & 4.84 \\ 328.295 & 0.14 & 25.81\end{array}$

$\begin{array}{lll}1.272 .142 & 0.56 \quad 100.00\end{array}$

$\begin{array}{rlrr}410.368 & 0.18 & 32.26 & 1 \\ 471.924 & 0.21 & 37.10 & 2 \\ 61.555 & 0.03 & 4.84 & 3 \\ 328.295 & 0.14 & 25.81 & 4 \\ --- & ------- & & \end{array}$

----- $\quad$---------

$1.149 .032 \quad 0.50$

$\begin{array}{rrr}451.405 & 0.20 & 39.29 \\ 205.184 & 0.09 & 17.86 \\ 61.555 & 0.03 & 5.36 \\ 205.184 & 0.09 & 17.86 \\ 225.703 & 0.10 & 19.64\end{array}$

$\begin{array}{lll}1.149 .032 & 0.50 \quad 100.00\end{array}$

$\begin{array}{rlrr}451.405 & 0.20 & 39.29 & 1 \\ 205.184 & 0.09 & 17.86 & 2 \\ 61.555 & 0.03 & 5.36 & 3 \\ 205.184 & 0.09 & 17.86 & 4 \\ 225.703 & 0.10 & 19.64 & 5 \\ --- & ------- & & \end{array}$

----- ---------

Area [ha] \%Microb. \%Sub-b. N.HRUs

$1.949 .250 \quad 0.85$

$\begin{array}{ll}553.997 & 0.24\end{array}$

$389.850 \quad 0.17$

$102.592 \quad 0.04$

28.42

$\begin{array}{lll}451.405 & 0.20 & 23.16\end{array}$

$\begin{array}{lll}102.592 & 0.04 & 5.26\end{array}$

$\begin{array}{lll}348.813 & 0.15 & 17.89\end{array}$ 
Solo

Latossolo Amare1o

HRUS:

593 Pastagem/Latossolo Amarelo

594 Cana-de-açúcar/Latossolo Amarelo

595 Cerrado/Latossolo Amarelo

596 Área Residencia1/Latossolo Amarelo

597 Agricultura Genérica/Latossolo Amarelo

598 Laranja/Latossolo Amarelo

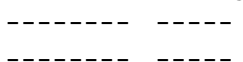

Sub-bacia 40

Uso do solo

Pastagem

Cana-de-açúcar

Cerrado

Área residencial

Agricultura Genérica

Laranja

Solo

Latossolo Amare1o

Neossolo Quartzarênico

HRUS:

599 Pastagem/Latossolo Amare1o

600 Pastagem/Neossolo Quartzarênico

601 Cana-de-açúcar/Latossolo Amarelo

602 Cana-de-açúcar/Neossolo Quartzarênico

603 Cerrado/Latossolo Amarelo

604 Cerrado/Neossolo Quartzarênico

605 Área Residencial/Latossolo Amarelo

606 Agricultura Genérica/Latossolo Amarelo Agricultura Genérica/Neossolo

607 Quartzarênico

608 Laranja/Latossolo Amarelo

609 Laranja/Neossolo Quartzarênico

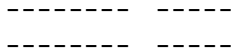

Sub-bacia 41

Uso do solo

Pastagem

Cana-de-açúcar

Mata

Cerrado

Ref1orestamento

Área residencial

Agricultura Genérica

Laranja

Solo

Gleissolo

Latossolo Amare1o

Neossolo Quartzarênico

HRUS:

610 Pastagem/Gleissolo

611 Pastagem/Latossolo Amare1o

612 Pastagem/Neossolo Quartzarênico

613 Cana-de-açúcar/Latossolo Amare1o
$1.949 .250 \quad 0.85 \quad 100.00$

$\begin{array}{rlrr}553.997 & 0.24 & 28.42 & 1 \\ 389.850 & 0.17 & 20.00 & 2 \\ 102.592 & 0.04 & 5.26 & 3 \\ 451.405 & 0.20 & 23.16 & 4 \\ 102.592 & 0.04 & 5.26 & 5 \\ 348.813 & 0.15 & 17.89 & 6 \\ ---- & ------- & \end{array}$

Area [ha] \%Microb. \%Sub-b. N.HRUs

$2.174 .953 \quad 0.95$

$\begin{array}{rrr}1.169 .550 & 0.51 & 53.77 \\ 164.147 & 0.07 & 7.55 \\ 246.221 & 0.11 & 11.32 \\ 20.518 & 0.01 & 0.94 \\ 205.184 & 0.09 & 9.43 \\ 369.332 & 0.16 & 16.98\end{array}$

$\begin{array}{lll}1.497 .845 & 0.65 & 68.87\end{array}$

$\begin{array}{lll}677.108 & 0.30 \quad 31.13\end{array}$

$\begin{array}{llll}738.663 & 0.32 & 33.96 & 1\end{array}$

$\begin{array}{llll}430.887 & 0.19 & 19.81 & 2\end{array}$

$\begin{array}{llll}102.592 & 0.04 & 4.72 & 3\end{array}$

$\begin{array}{llll}61.555 & 0.03 & 2.83 & 4\end{array}$

$\begin{array}{llll}225.703 & 0.10 & 10.38 & 5\end{array}$

$\begin{array}{llll}20.518 & 0.01 & 0.94 & 6\end{array}$

$\begin{array}{llll}20.518 & 0.01 & 0.94 & 7\end{array}$

$\begin{array}{llll}143.629 & 0.06 & 6.60 & 8\end{array}$

$\begin{array}{llll}61.555 & 0.03 & 2.83 & 9\end{array}$

$\begin{array}{llll}266.740 & 0.12 & 12.26 & 10\end{array}$

$\begin{array}{llll}102.592 & 0.04 & 4.72 & 11\end{array}$

Area [ha] \%Microb. \%Sub-b. N.HRUs

$5.622 .047 \quad 2.46$

$\begin{array}{rrr}718.145 & 0.31 & 12.77 \\ 205.184 & 0.09 & 3.65 \\ 410.368 & 0.18 & 7.30 \\ 718.145 & 0.31 & 12.77 \\ 369.332 & 0.16 & 6.57 \\ .421 .174 & 1.06 & 43.07 \\ 102.592 & 0.04 & 1.82 \\ 677.108 & 0.30 & 12.04\end{array}$

$\begin{array}{lll}225.703 & 0.10 & 4.01\end{array}$

$\begin{array}{lll}3.077 .763 & 1.35 & 54.74\end{array}$

$2.318 .581 \quad 1.01 \quad 41.24$

$\begin{array}{rrrr}20.518 & 0.01 & 0.36 & 1 \\ 143.629 & 0.06 & 2.55 & 2 \\ 553.997 & 0.24 & 9.85 & 3 \\ 102.592 & 0.04 & 1.82 & 4\end{array}$


614 Cana-de-açúcar/Neossolo Quartzarênico

$102.592 \quad 0.04$

$102.592 \quad 0.04$

$102.592 \quad 0.04$

1.82

615 Mata/Gleissolo

616 Mata/Latossolo Amarelo

$205.184 \quad 0.09$

$102.592 \quad 0.04$

$328.295 \quad 0.14$

$287.258 \quad 0.13$

$266.739 \quad 0.12$

1.82

617 Mata/Neossolo Quartzarênico

618 Cerrado/Gleissolo

619 Cerrado/Latossolo Amare1o

620 Cerrado/Neossolo Quartzarênico

621 Reflorestamento/Latossolo Amarelo

622 Reflorestamento/Neossolo Quartzarênico

$102.592 \quad 0.04$

$\begin{array}{ll}1.600 .437 & 0.70\end{array}$

$820.737 \quad 0.36$

$61.555 \quad 0.03$

1.827

624 Área Residencial/Neossolo Quartzarênico

625 Agricultura Genérica/Latossolo Amarelo

$3.65 \quad 8$

Agricultura Genérica/Neossolo

626 Quartzarênico

627 Laranja/Latossolo Amarelo

628 Laranja/Neossolo Quartzarênico

$\begin{array}{ll}41.037 & 0.02\end{array}$

1.829

$5.84 \quad 10$

$5.11 \quad 11$

$4.74 \quad 12$

$1.82 \quad 13$

$28.47 \quad 14$

$14.60 \quad 15$

$1.09 \quad 16$

$\begin{array}{llll}.924 & 0.21 & 8.39 & 18\end{array}$

$\begin{array}{llll}205.184 & 0.09 & 3.65 & 19\end{array}$ 
APÊNDICE II 
Tabela 48. Valores de entrada de nutrientes para cada HRU, nas sub-bacias que contêm granjas.

\begin{tabular}{|c|c|c|c|c|c|c|c|}
\hline $\begin{array}{l}\text { Sub- } \\
\text { bacia }\end{array}$ & $\begin{array}{c}\text { Área da sub- } \\
\text { bacia } \\
\text { (ha) }\end{array}$ & $\begin{array}{l}\text { Nitrogênio }(\mathrm{N}) \text { na } \\
\text { sub-bacia } \\
\text { (Kg/mês) }\end{array}$ & $\begin{array}{c}\text { Fósforo }(\mathrm{P}) \text { na } \\
\text { sub-bacia } \\
\text { (Kg/mês) }\end{array}$ & HRUs & $\begin{array}{l}\text { Área da } \\
\text { HRU (ha) }\end{array}$ & $\begin{array}{c}\text { Nitrogênio (N) na } \\
\text { HRU } \\
(\mathrm{Kg} / \mathrm{mês} / \mathrm{ha})\end{array}$ & $\begin{array}{c}\text { Fósforo }(P) \text { na } \\
\text { HRU } \\
\text { (Kg/mês/ha) }\end{array}$ \\
\hline \multirow{17}{*}{4} & \multirow{17}{*}{$3.898,50$} & \multirow{17}{*}{$1.500,52$} & \multirow{17}{*}{259,2} & Pastagem/Gleissolo & 20,52 & 7,8973 & 1,3642 \\
\hline & & & & Pastagem/Latossolo Amarelo & $1.231,11$ & 473,8499 & 81,8526 \\
\hline & & & & Cana-de-açucar/Argissolo & 102,59 & 39,4875 & 6,8210 \\
\hline & & & & Cana-de-açucar/Gleissolo & 123,11 & 47,3852 & 8,1853 \\
\hline & & & & Cana-de-açucar/Latossolo Amarelo & 759,18 & 292,2077 & 50,4758 \\
\hline & & & & $\begin{array}{l}\text { Cana-de-açucar/Latossolo vermelho } \\
\text { eutroférrico }\end{array}$ & 184,67 & 71,0776 & 12,2779 \\
\hline & & & & Mata/Latossolo vermelho eutroférrico & 164,15 & 63,1799 & 10,9137 \\
\hline & & & & Cerrado/Gleissolo & 20,52 & 7,8973 & 1,3642 \\
\hline & & & & Cerrado/Latossolo Amarelo & 225,70 & 86,8726 & 15,0063 \\
\hline & & & & Cerrado/Latossolo vermelho eutroférrico & 102,59 & 39,4875 & 6,8210 \\
\hline & & & & Reflorestamento/Latossolo Amarelo & 20,52 & 7,8973 & 1,3642 \\
\hline & & & & Área residencial/Latossolo Amarelo & 287,26 & 110,5650 & 19,0990 \\
\hline & & & & Agric. Genérica/Latossolo Amarelo & 123,11 & 47,3852 & 8,1853 \\
\hline & & & & $\begin{array}{l}\text { Agric. Genérica/Latossolo vermelho } \\
\text { eutroférrico }\end{array}$ & 20,52 & 7,8973 & 1,3642 \\
\hline & & & & Laranja/Argissolo & 61,56 & 23,6924 & 4,0926 \\
\hline & & & & Laranja/Latossolo Amarelo & 287,26 & 110,5650 & 19,0990 \\
\hline & & & & Laranja/Latossolo vermelho eutroférrico & 164,15 & 63,1799 & 10,9137 \\
\hline \multirow{14}{*}{10} & \multirow{14}{*}{$5.375,83$} & \multirow{14}{*}{555,75} & \multirow{14}{*}{96} & Pastagem/Gleissolo & 636,07 & 65,7567 & 11,3588 \\
\hline & & & & Pastagem/Neossolo Litólico & 512,96 & 53,0295 & 9,1603 \\
\hline & & & & Pastagem/Latossolo Amarelo & $1.415,77$ & 146,3616 & 25,2824 \\
\hline & & & & Pastagem/Neossolo Quartzarênico & 246,22 & 25,4542 & 4,3969 \\
\hline & & & & Cana-de-açucar/Gleissolo & 82,07 & 8,4848 & 1,4657 \\
\hline & & & & Cana-de-açucar/Latossolo Amarelo & 820,74 & 84,8473 & 14,6565 \\
\hline & & & & Cana-de-açucar/Neossolo Quartzarênico & 20,52 & 2,1211 & 0,3664 \\
\hline & & & & Mata/Gleissolo & 20,52 & 2,1211 & 0,3664 \\
\hline & & & & Mata/Latossolo Amarelo & 20,52 & 2,1211 & 0,3664 \\
\hline & & & & Cerrado/Gleissolo & 123,11 & 12,7271 & 2,1985 \\
\hline & & & & Cerrado/Neossolo Litólico & 184,67 & 19,0907 & 3,2977 \\
\hline & & & & Cerrado/Latossolo Amarelo & 307,78 & 31,8177 & 5,4962 \\
\hline & & & & Reflorestamento/Neossolo Litólico & 20,52 & 2,1211 & 0,3664 \\
\hline & & & & Reflorestamento/Latossolo Amarelo & 20,52 & 2,1211 & 0,3664 \\
\hline
\end{tabular}




\section{Continuação...}

\begin{tabular}{|c|c|c|c|c|c|c|c|}
\hline $\begin{array}{l}\text { Sub- } \\
\text { bacia }\end{array}$ & $\begin{array}{l}\text { Área da sub- } \\
\text { bacia } \\
\text { (ha) } \\
\end{array}$ & $\begin{array}{c}\text { Nitrogênio }(\mathrm{N}) \text { na } \\
\text { sub-bacia } \\
\text { (Kg/mês) }\end{array}$ & $\begin{array}{c}\text { Fósforo }(\mathrm{P}) \text { na } \\
\text { sub-bacia } \\
\text { (Kg/mês) }\end{array}$ & HRUs & $\begin{array}{l}\text { Área da } \\
\text { HRU (ha) }\end{array}$ & $\begin{array}{c}\text { Nitrogênio (N) na } \\
\text { HRU } \\
\text { (Kg/mês/ha) }\end{array}$ & $\begin{array}{c}\text { Fósforo (P) na } \\
\text { HRU } \\
\text { (Kg/mês/ha) } \\
\end{array}$ \\
\hline \multirow{8}{*}{10} & \multirow{8}{*}{$5.375,83$} & \multirow{8}{*}{555,75} & \multirow{8}{*}{96} & Área residencial/Latossolo Amarelo & 61,56 & 6,3635 & 1,0992 \\
\hline & & & & Agric. Genérica/Neossolo Litólico & 20,52 & 2,1211 & 0,3664 \\
\hline & & & & Agric. Genérica/Latossolo Amarelo & 328,30 & 33,9390 & 5,8626 \\
\hline & & & & Agric. Genérica/Neossolo Quartzarênico & 41,04 & 4,2424 & 0,7328 \\
\hline & & & & Laranja/Gleissolo & 61,56 & 6,3635 & 1,0992 \\
\hline & & & & Laranja/Neossolo Litólico & 61,56 & 6,3635 & 1,0992 \\
\hline & & & & Laranja/Latossolo Amarelo & 205,18 & 21,2118 & 3,6641 \\
\hline & & & & Laranja/Neossolo Quartzarênico & 164,15 & 16,9694 & 2,9313 \\
\hline \multirow{23}{*}{20} & \multirow{23}{*}{$3.282,95$} & \multirow{23}{*}{833,62} & \multirow{23}{*}{144} & Pastagem/Latossolo Amarelo & 61.555 & 15,6304 & 2,7000 \\
\hline & & & & Pastagem/Latossolo vermelho eutroférrico & 20.518 & 5,2100 & 0,9000 \\
\hline & & & & Pastagem/Latossolo vermelho mesoférrico & 410.368 & 104,2030 & 18,0000 \\
\hline & & & & Pastagem/Neossolo Quartzarênico & 123.111 & 31,2611 & 5,4000 \\
\hline & & & & Cana-de-açúcar/Gleissolo & 41.037 & 10,4204 & 1,8000 \\
\hline & & & & Cana-de-açúcar/Latossolo Amarelo & 41.037 & 10,4204 & 1,8000 \\
\hline & & & & $\begin{array}{l}\text { Cana-de-açúcar/Latossolo vermelho } \\
\text { eutroférrico }\end{array}$ & 20.518 & 5,2100 & 0,9000 \\
\hline & & & & $\begin{array}{l}\text { Cana-de-açúcar/Latossolo vermelho } \\
\text { mesoférrico }\end{array}$ & 328.295 & 83,3626 & 14,4000 \\
\hline & & & & Cana-de-açúcar/Neossolo Quartzarênico & 553.997 & 140,6741 & 24,3000 \\
\hline & & & & Mata/Gleissolo & 20.518 & 5,2100 & 0,9000 \\
\hline & & & & Mata/Neossolo Quartzarênico & 102.592 & 26,0508 & 4,5000 \\
\hline & & & & Cerrado/Gleissolo & 184.666 & 46,8915 & 8,1000 \\
\hline & & & & Cerrado/Latossolo vermelho mesoférrico & 41.037 & 10,4204 & 1,8000 \\
\hline & & & & Cerrado/Neossolo Quartzarênico & 164.147 & 41,6812 & 7,2000 \\
\hline & & & & $\begin{array}{l}\text { Reflorestamento/Latossolo vermelho } \\
\text { mesoférrico }\end{array}$ & 20.518 & 5,2100 & 0,9000 \\
\hline & & & & Agricultura Genérica/Gleissolo & 184.666 & 46,8915 & 8,1000 \\
\hline & & & & $\begin{array}{l}\text { Agricultura Genérica/Latossolo vermelho } \\
\text { mesoférrico }\end{array}$ & 61.555 & 15,6304 & 2,7000 \\
\hline & & & & Agric. Genérica/Neossolo Quartzarênico & 369.332 & 93,7829 & 16,2000 \\
\hline & & & & Laranja/Gleissolo & 41.037 & 10,4204 & 1,8000 \\
\hline & & & & Laranja/Latossolo Amarelo & 20.518 & 5,2100 & 0,9000 \\
\hline & & & & Laranja/Latossolo vermelho eutroférrico & 20.518 & 5,2100 & 0,9000 \\
\hline & & & & Laranja/Latossolo vermelho mesoférrico & 410.368 & 104,2030 & 18,0000 \\
\hline & & & & Laranja/Neossolo Quartzarênico & 41.037 & 10,4204 & 1,8000 \\
\hline
\end{tabular}




\section{Continuação...}

\begin{tabular}{|c|c|c|c|c|c|c|c|}
\hline $\begin{array}{l}\text { Sub- } \\
\text { bacia }\end{array}$ & $\begin{array}{l}\text { Área da sub- } \\
\text { bacia } \\
\text { (ha) } \\
\end{array}$ & $\begin{array}{c}\text { Nitrogênio }(\mathrm{N}) \text { na } \\
\text { sub-bacia } \\
\text { (Kg/mês) }\end{array}$ & $\begin{array}{c}\text { Fósforo }(\mathrm{P}) \text { na } \\
\text { sub-bacia } \\
\text { (Kg/mês) }\end{array}$ & HRUs & $\begin{array}{l}\text { Área da } \\
\text { HRU (ha) }\end{array}$ & $\begin{array}{c}\text { Nitrogênio (N) na } \\
\text { HRU } \\
\text { (Kg/mês/ha) }\end{array}$ & $\begin{array}{c}\text { Fósforo (P) na } \\
\text { HRU } \\
\text { (Kg/mês/ha) } \\
\end{array}$ \\
\hline \multirow{24}{*}{22} & \multirow{24}{*}{$6.853,15$} & \multirow{24}{*}{$2.389,72$} & \multirow{24}{*}{412,8} & Pastagem/Latossolo vermelho eutroférrico & 146,26 & 51,0001 & 8,8097 \\
\hline & & & & Pastagem/Latossolo vermelho mesoférrico & 376,09 & 131,1436 & 22,6537 \\
\hline & & & & Pastagem/Neossolo Quartzarênico & 919,33 & 320,5728 & 55,3756 \\
\hline & & & & $\begin{array}{l}\text { Cana-de-açúcar/Latossolo vermelho } \\
\text { eutroférrico }\end{array}$ & 313,41 & 109,2861 & 18,8780 \\
\hline & & & & $\begin{array}{l}\text { Cana-de-açúcar/Latossolo vermelho } \\
\text { mesoférrico }\end{array}$ & $2.005,80$ & 699,4319 & 120,8195 \\
\hline & & & & Cana-de-açúcar/Neossolo Quartzarênico & $1.211,84$ & 422,5734 & 72,9951 \\
\hline & & & & Mata/Gleissolo & 20,89 & 7,2858 & 1,2586 \\
\hline & & & & Mata/Latossolo vermelho eutroférrico & 125,36 & 43,7146 & 7,5512 \\
\hline & & & & Mata/Latossolo vermelho mesoférrico & 167,15 & 58,2860 & 10,0683 \\
\hline & & & & Mata/Neossolo Quartzarênico & 41,79 & 14,5717 & 2,5171 \\
\hline & & & & Cerrado/Gleissolo & 20,89 & 7,2858 & 1,2586 \\
\hline & & & & Cerrado/Latossolo vermelho eutroférrico & 83,58 & 29,1430 & 5,0341 \\
\hline & & & & Cerrado/Latossolo vermelho mesoférrico & 334,30 & 116,5719 & 20,1366 \\
\hline & & & & Cerrado/Neossolo Quartzarênico & 250,73 & 87,4289 & 15,1024 \\
\hline & & & & $\begin{array}{l}\text { Reflorestamento/Latossolo vermelho } \\
\text { eutroférrico }\end{array}$ & 104,47 & 36,4288 & 6,2927 \\
\hline & & & & $\begin{array}{l}\text { Reflorestamento/Latossolo vermelho } \\
\text { mesoférrico }\end{array}$ & 41,79 & 14,5717 & 2,5171 \\
\hline & & & & Reflorestamento/Neossolo Quartzarênico & 20,89 & 7,2858 & 1,2586 \\
\hline & & & & Agricultura Genérica/Gleissolo & 62,68 & 21,8571 & 3,7756 \\
\hline & & & & $\begin{array}{l}\text { Agricultura Genérica/Latossolo vermelho } \\
\text { mesoférrico }\end{array}$ & 188,04 & 65,5718 & 11,3268 \\
\hline & & & & Agric. Genérica/Neossolo Quartzarênico & 83,58 & 29,1430 & 5,0341 \\
\hline & & & & Laranja/Gleissolo & 20,89 & 7,2858 & 1,2586 \\
\hline & & & & Laranja/Latossolo vermelho eutroférrico & 41,79 & 14,5717 & 2,5171 \\
\hline & & & & Laranja/Latossolo vermelho mesoférrico & 167,15 & 58,2860 & 10,0683 \\
\hline & & & & Laranja/Neossolo Quartzarênico & 104,47 & 36,4288 & 6,2927 \\
\hline \multirow{8}{*}{24} & \multirow{8}{*}{$5.457,90$} & \multirow{8}{*}{$1.333,8$} & \multirow{8}{*}{230,4} & Pastagem/Latossolo vermelho eutroférrico & 143,63 & 35,1000 & 6,0632 \\
\hline & & & & Pastagem/Latossolo vermelho mesoférrico & 123,11 & 30,0858 & 5,1970 \\
\hline & & & & Pastagem/Neossolo Quartzarênico & 512,96 & 125,3570 & 21,6541 \\
\hline & & & & $\begin{array}{l}\text { Cana-de-açúcar/Latossolo vermelho } \\
\text { eutroférrico }\end{array}$ & 287,26 & 70,2000 & 12,1263 \\
\hline & & & & $\begin{array}{l}\text { Cana-de-açúcar/Latossolo vermelho } \\
\text { mesoférrico }\end{array}$ & 779,70 & 190,5429 & 32,9143 \\
\hline & & & & Cana-de-açúcar/Neossolo Quartzarênico & $1.251,62$ & 305,8713 & 52,8361 \\
\hline & & & & Mata/Latossolo vermelho eutroférrico & 266,74 & 65,1856 & 11,2601 \\
\hline & & & & Mata/Latossolo vermelho mesoférrico & 20,52 & 5,0142 & 0,8661 \\
\hline
\end{tabular}




\begin{tabular}{|c|c|c|c|c|c|c|c|}
\hline $\begin{array}{l}\text { Sub- } \\
\text { bacia }\end{array}$ & $\begin{array}{c}\text { Área da sub- } \\
\text { bacia } \\
\text { (ha) }\end{array}$ & $\begin{array}{l}\text { Nitrogênio }(\mathrm{N}) \text { na } \\
\text { sub-bacia } \\
\text { (Kg/mês) }\end{array}$ & $\begin{array}{c}\text { Fósforo }(P) \text { na } \\
\text { sub-bacia } \\
\text { (Kg/mês) }\end{array}$ & HRUs & $\begin{array}{l}\text { Área da } \\
\text { HRU (ha) }\end{array}$ & $\begin{array}{c}\text { Nitrogênio (N) na } \\
\text { HRU } \\
\text { (Kg/mês/ha) }\end{array}$ & $\begin{array}{c}\text { Fósforo }(\mathrm{P}) \text { na } \\
\text { HRU } \\
\text { (Kg/mês/ha) }\end{array}$ \\
\hline \multirow{13}{*}{24} & \multirow{13}{*}{$5.457,90$} & \multirow{13}{*}{$1.333,8$} & \multirow{13}{*}{230,4} & Mata/Neossolo Quartzarênico & 287,26 & 70,2000 & 12,1263 \\
\hline & & & & Cerrado/Latossolo vermelho eutroférrico & 471,92 & 115,3287 & 19,9218 \\
\hline & & & & Cerrado/Latossolo vermelho mesoférrico & 61,56 & 15,0428 & 2,5985 \\
\hline & & & & Cerrado/Neossolo Quartzarênico & 164,15 & 40,1142 & 6,9293 \\
\hline & & & & $\begin{array}{l}\text { Reflorestamento/Latossolo vermelho } \\
\text { eutroférrico }\end{array}$ & 20,52 & 5,0142 & 0,8661 \\
\hline & & & & Reflorestamento/Neossolo Quartzarênico & 123,11 & 30,0858 & 5,1970 \\
\hline & & & & Agricultura Genérica/Gleissolo & 41,04 & 10,0286 & 1,7323 \\
\hline & & & & $\begin{array}{l}\text { Agricultura Genérica/Latossolo vermelho } \\
\text { eutroférrico }\end{array}$ & 20,52 & 5,0142 & 0,8661 \\
\hline & & & & $\begin{array}{l}\text { Agricultura Genérica/Latossolo vermelho } \\
\text { mesoférrico }\end{array}$ & 41,04 & 10,0286 & 1,7323 \\
\hline & & & & Agric. Genérica/Neossolo Quartzarênico & 82,07 & 20,0572 & 3,4647 \\
\hline & & & & Laranja/Latossolo vermelho eutroférrico & 328,30 & 80,2287 & 13,8587 \\
\hline & & & & Laranja/Latossolo vermelho mesoférrico & 41,04 & 10,0286 & 1,7323 \\
\hline & & & & Laranja/Neossolo Quartzarênico & 389,85 & 95,2714 & 16,4571 \\
\hline \multirow{22}{*}{28} & \multirow{22}{*}{$11.285,13$} & \multirow{22}{*}{305,66} & \multirow{22}{*}{52,8} & Pastagem/Latossolo Amarelo & 614,01 & 16,6308 & 2,8728 \\
\hline & & & & $\begin{array}{l}\text { Pastagem/Latossolo vermelho } \\
\text { eutroférrico }\end{array}$ & 254,07 & 6,8817 & 1,1887 \\
\hline & & & & $\begin{array}{l}\text { Pastagem/Latossolo vermelho } \\
\text { mesoférrico }\end{array}$ & 21,17 & 0,5735 & 0,0991 \\
\hline & & & & Pastagem/Neossolo Quartzarênico & 359,94 & 9,7491 & 1,6841 \\
\hline & & & & Cana-de-açúcar/Latossolo Amarelo & 381,11 & 10,3226 & 1,7831 \\
\hline & & & & $\begin{array}{l}\text { Cana-de-açúcar/Latossolo vermelho } \\
\text { eutroférrico }\end{array}$ & 232,90 & 6,3082 & 1,0897 \\
\hline & & & & Cana-de-açúcar/Neossolo Quartzarênico & 762,22 & 20,6451 & 3,5662 \\
\hline & & & & Mata/Latossolo Amarelo & 338,77 & 9,1756 & 1,5850 \\
\hline & & & & Mata/Latossolo vermelho mesoférrico & 63,52 & 1,7204 & 0,2972 \\
\hline & & & & Mata/Neossolo Quartzarênico & 84,69 & 2,2939 & 0,3962 \\
\hline & & & & Cerrado/Latossolo Amarelo & 635,19 & 17,2043 & 2,9719 \\
\hline & & & & Cerrado/Latossolo vermelho eutroférrico & 42,35 & 1,1470 & 0,1981 \\
\hline & & & & Cerrado/Latossolo vermelho mesoférrico & 105,86 & 2,8674 & 0,4953 \\
\hline & & & & Cerrado/Neossolo Quartzarênico & 84,69 & 2,2939 & 0,3962 \\
\hline & & & & Reflorestamento/Latossolo Amarelo & 254,07 & 6,8817 & 1,1887 \\
\hline & & & & Reflorestamento/Latos. verm. Mesofér. & 21,17 & 0,5735 & 0,0991 \\
\hline & & & & Reflorestamento/Neossolo Quartzarênico & 42,35 & 1,1470 & 0,1981 \\
\hline & & & & Agricultura Genérica/Latossolo Amarelo & 105,86 & 2,8674 & 0,4953 \\
\hline & & & & Agric. Genérica/Neossolo Quartzarênico & 105,86 & 2,8674 & 0,4953 \\
\hline & & & & Laranja/Latossolo Amarelo & $5.399,08$ & 146,2363 & 25,2608 \\
\hline & & & & Laranja/Latossolo vermelho mesoférrico & 635,19 & 17,2043 & 2,9719 \\
\hline & & & & Laranja/Neossolo Quartzarênico & 741,05 & 20,0716 & 3,4672 \\
\hline
\end{tabular}




\section{Continuação...}

\begin{tabular}{|c|c|c|c|c|c|c|c|}
\hline $\begin{array}{l}\text { Sub- } \\
\text { bacia }\end{array}$ & $\begin{array}{l}\text { Área da sub- } \\
\text { bacia } \\
\text { (ha) } \\
\end{array}$ & $\begin{array}{c}\text { Nitrogênio (N) na } \\
\text { sub-bacia } \\
\text { (Kg/mês) }\end{array}$ & $\begin{array}{c}\text { Fósforo }(\mathrm{P}) \text { na } \\
\text { sub-bacia } \\
\text { (Kg/mês) }\end{array}$ & HRUs & $\begin{array}{l}\text { Área da } \\
\text { HRU (ha) }\end{array}$ & $\begin{array}{c}\begin{array}{c}\text { Nitrogênio (N) na } \\
\text { HRU } \\
\text { (Kg/mês/ha) }\end{array} \\
\end{array}$ & $\begin{array}{c}\text { Fósforo }(\mathrm{P}) \text { na } \\
\text { HRU } \\
\text { (Kg/mês/ha) } \\
\end{array}$ \\
\hline \multirow{16}{*}{30} & \multirow{16}{*}{$11.141,50$} & \multirow{16}{*}{$2.500,87$} & \multirow{16}{*}{ 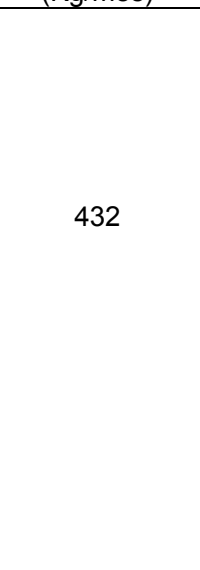 } & Pastagem/Neossolo Litólico & 21,39 & 4,8002 & 0,8292 \\
\hline & & & & Pastagem/Latossolo Amarelo & $2.159,87$ & 484,8146 & 83,7466 \\
\hline & & & & Pastagem/Latossolo vermelho eutroférrico & 21,39 & 4,8002 & 0,8292 \\
\hline & & & & Água/Latossolo Amarelo & 21,39 & 4,8002 & 0,8292 \\
\hline & & & & Cana-de-açúcar/Neossolo Litólico & 192,46 & 43,2014 & 7,4626 \\
\hline & & & & Cana-de-açúcar/Latossolo Amarelo & $1.368,63$ & 307,2093 & 53,0672 \\
\hline & & & & $\begin{array}{l}\text { Cana-de-açúcar/Latossolo vermelho } \\
\text { eutroférrico }\end{array}$ & 470,47 & 105,6031 & 18,2418 \\
\hline & & & & Mata/Neossolo Litólico & 278,00 & 62,4019 & 10,7793 \\
\hline & & & & Mata/Latossolo Amarelo & 406,31 & 91,2027 & 15,7543 \\
\hline & & & & Cerrado/Neossolo Litólico & 384,93 & 86,4026 & 14,9251 \\
\hline & & & & Cerrado/Latossolo Amarelo & 898,16 & 201,6060 & 34,8253 \\
\hline & & & & Cerrado/Latossolo vermelho eutroférrico & 21,39 & 4,8002 & 0,8292 \\
\hline & & & & Reflorestamento/Neossolo Litólico & 128,31 & 28,8009 & 4,9750 \\
\hline & & & & Reflorestamento/Latossolo Amarelo & 171,08 & 38,4012 & 6,6334 \\
\hline & & & & Agricultura Genérica/Latossolo Amarelo & 85,54 & 19,2005 & 3,3167 \\
\hline & & & & Laranja/Latossolo Amarelo & $4.512,20$ & 1012,8303 & 174,9558 \\
\hline \multirow{6}{*}{39} & \multirow{6}{*}{$1.949,25$} & \multirow{6}{*}{416,81} & \multirow{6}{*}{72} & Pastagem/Latossolo Amarelo & 554,00 & 118,4624 & 20,4631 \\
\hline & & & & Cana-de-açúcar/Latossolo Amarelo & 389,85 & 83,3625 & 14,4000 \\
\hline & & & & Cerrado/Latossolo Amarelo & 102,59 & 21,9375 & 3,7895 \\
\hline & & & & Área Residencial/Latossolo Amarelo & 451,41 & 96,5249 & 16,6737 \\
\hline & & & & Agricultura Genérica/Latossolo Amarelo & 102,59 & 21,9375 & 3,7895 \\
\hline & & & & Laranja/Latossolo Amarelo & 348,81 & 74,5875 & 12,8842 \\
\hline
\end{tabular}


APÊNDICE III 

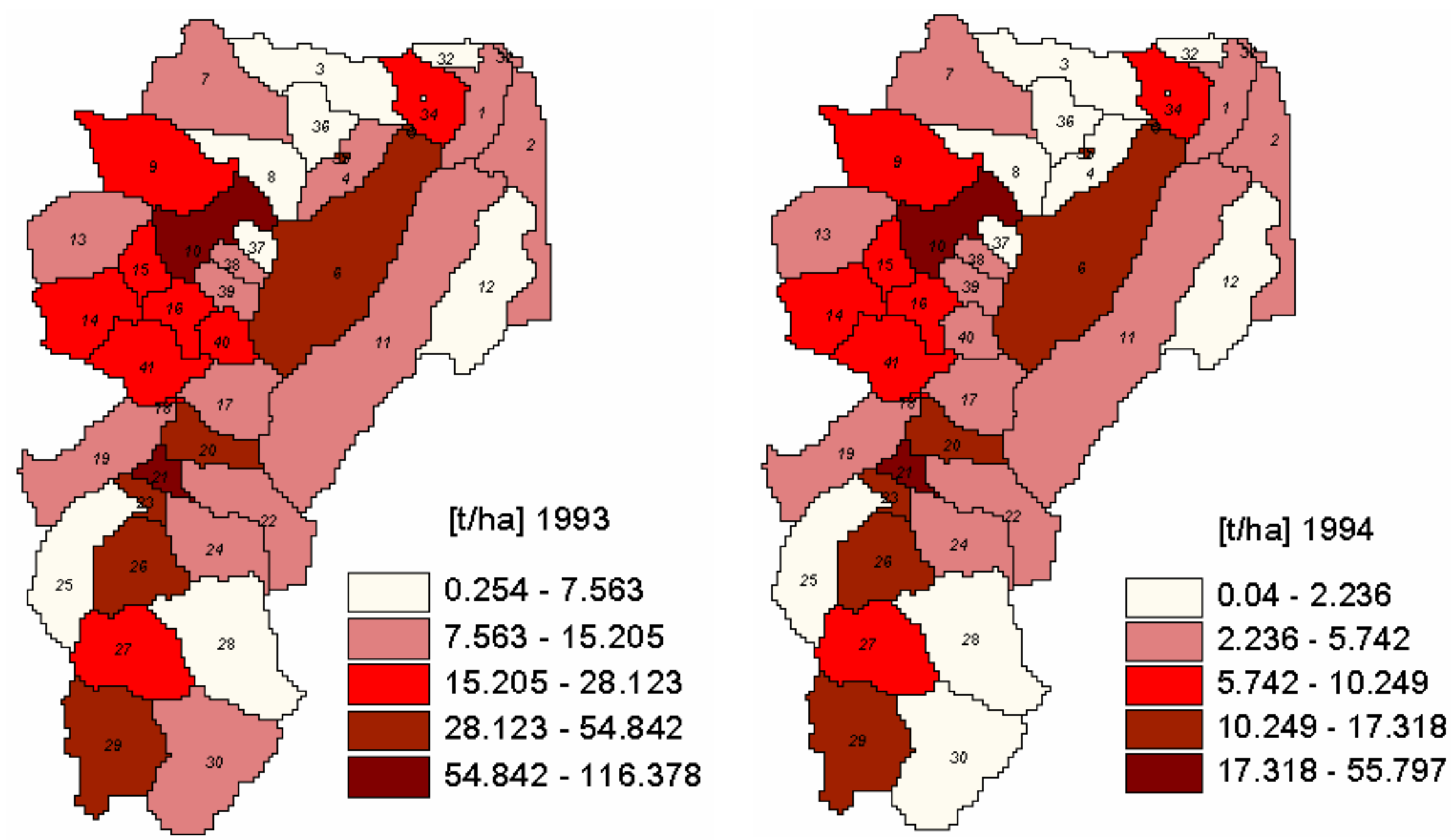

Figura 45. Distribuição espacial da produção anual de sedimentos (ton/ha) na MBHRB para os anos de 1993 e 1994. 

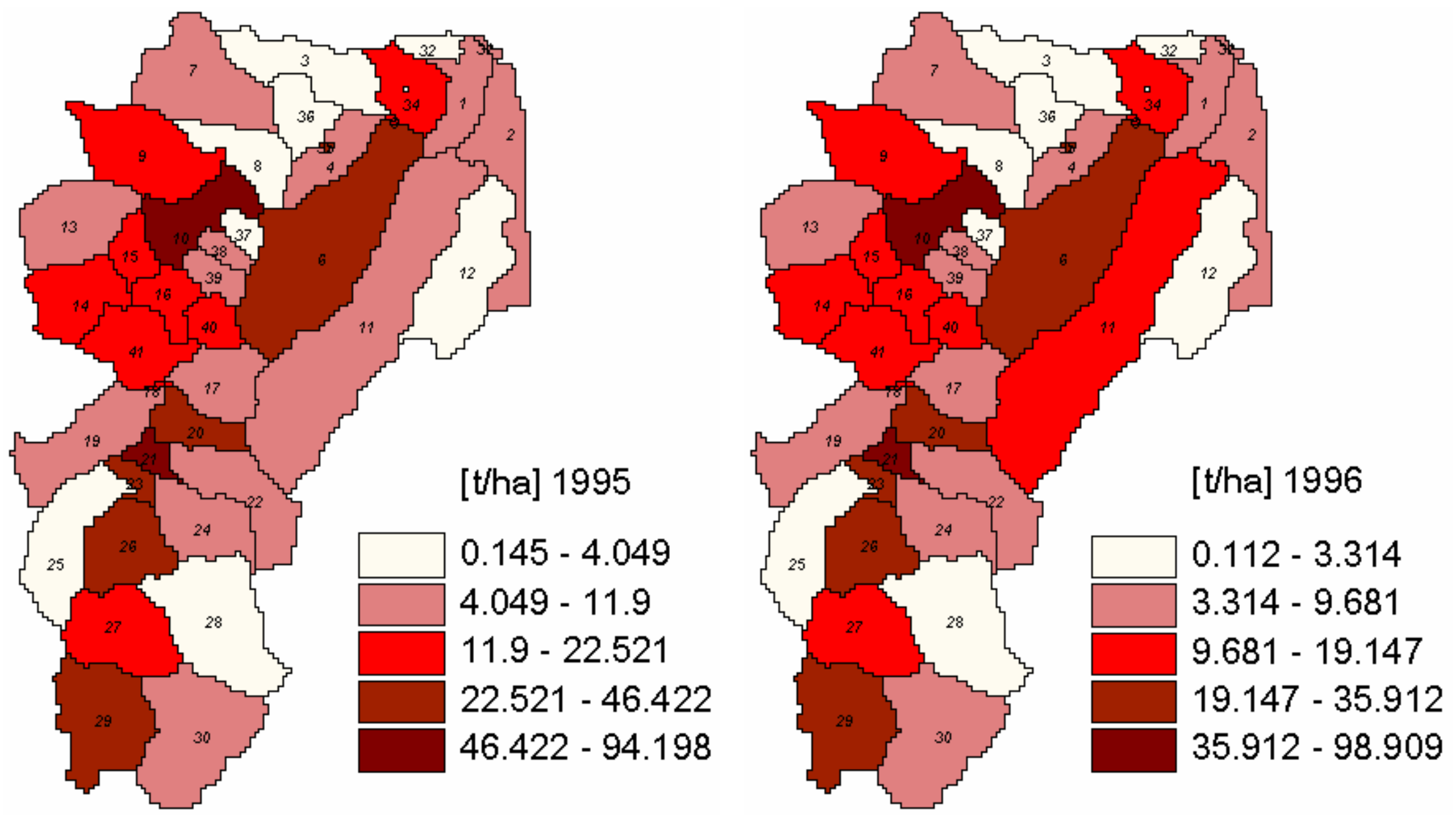

Figura 46. Distribuição espacial da produção anual de sedimentos (ton/ha) na MBHRB para os anos de 1995 e 1996. 

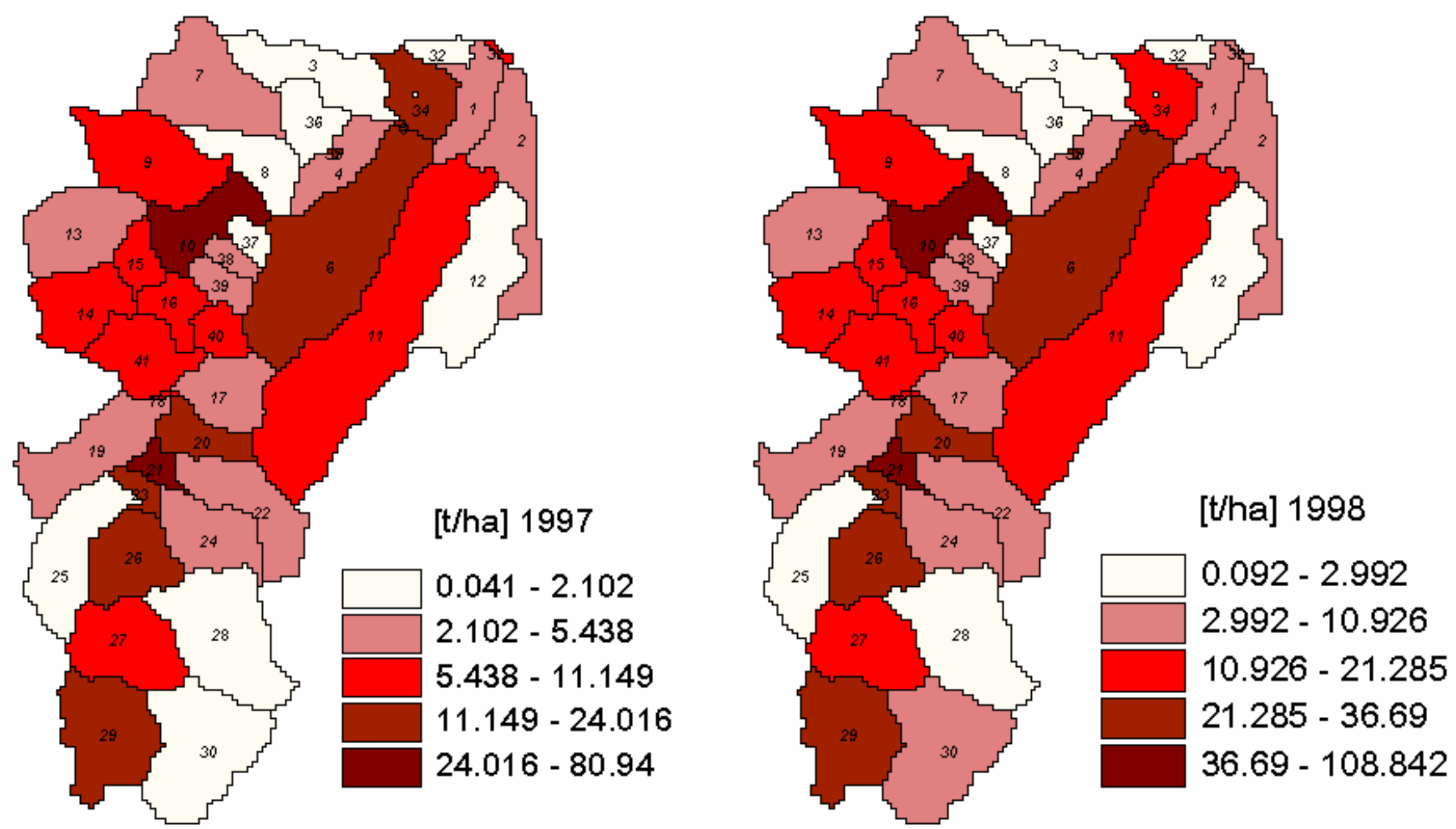

Figura 47. Distribuição espacial da produção anual de sedimentos (ton/ha) na MBHRB para os anos de 1997 e 1998. 

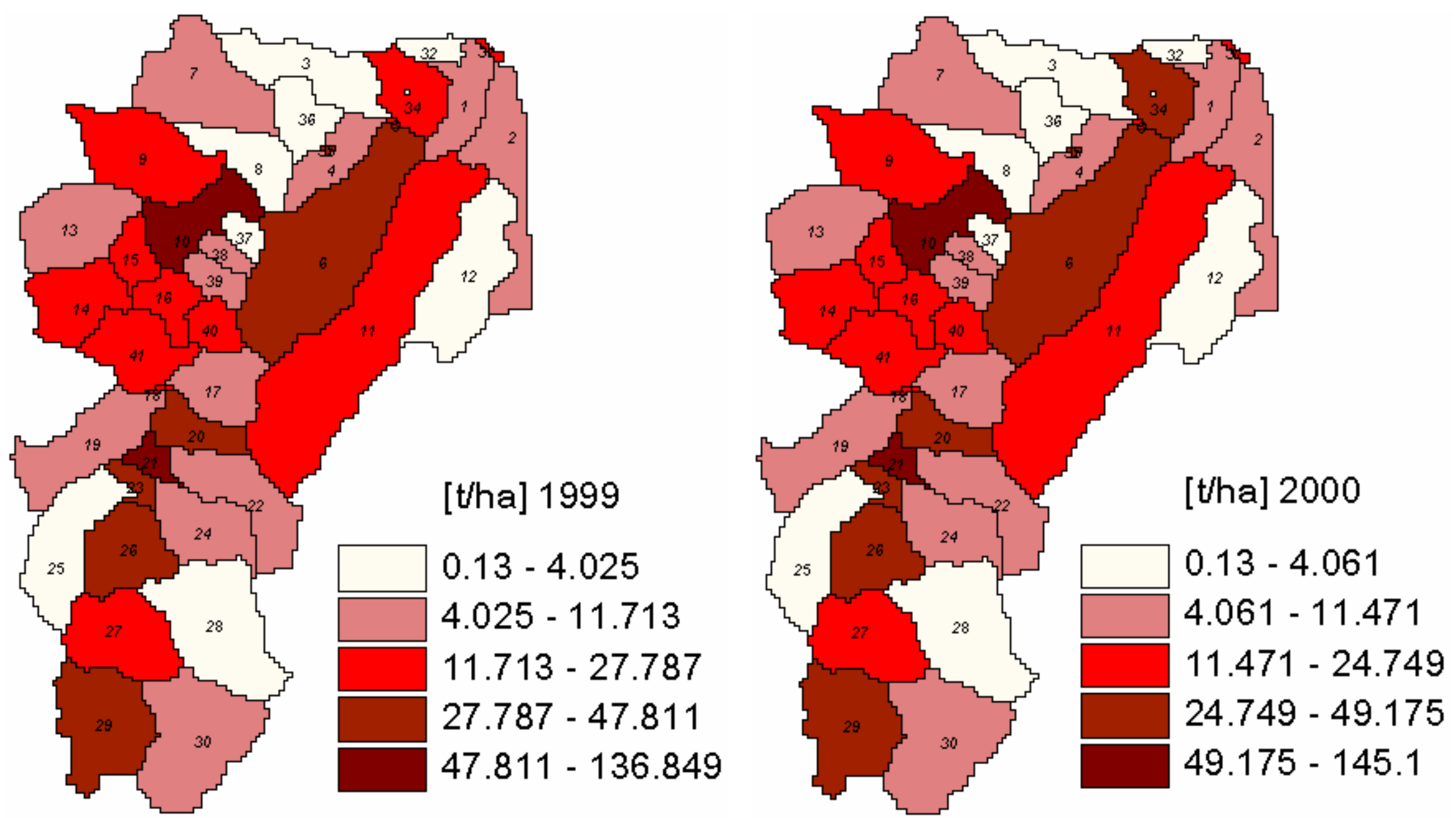

Figura 48. Distribuição espacial da produção anual de sedimentos (ton/ha) na MBHRB para os anos de 1999 e 2000. 

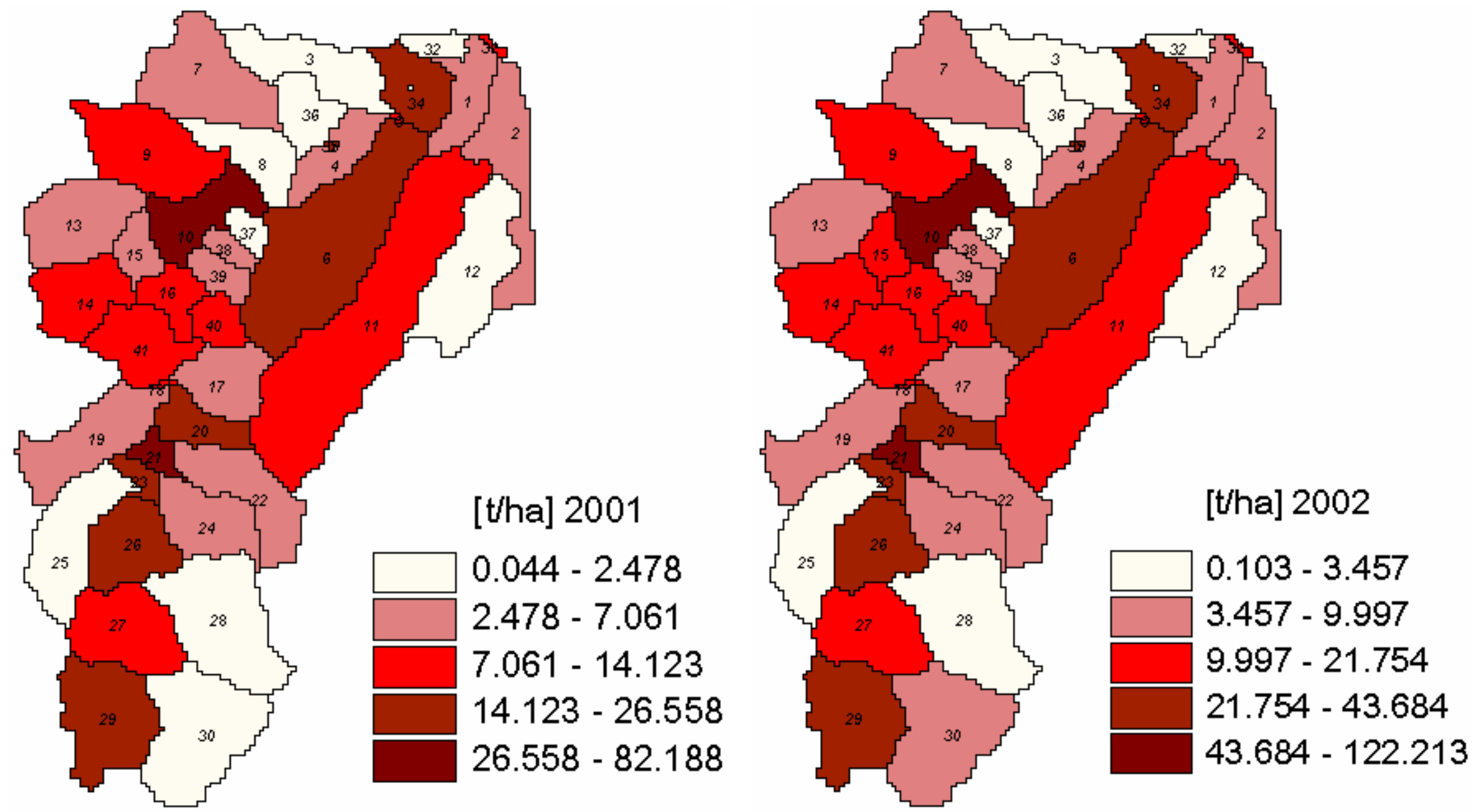

Figura 49. Distribuição espacial da produção anual de sedimentos (ton/ha) na MBHRB para os anos de 2001 e 2002. 

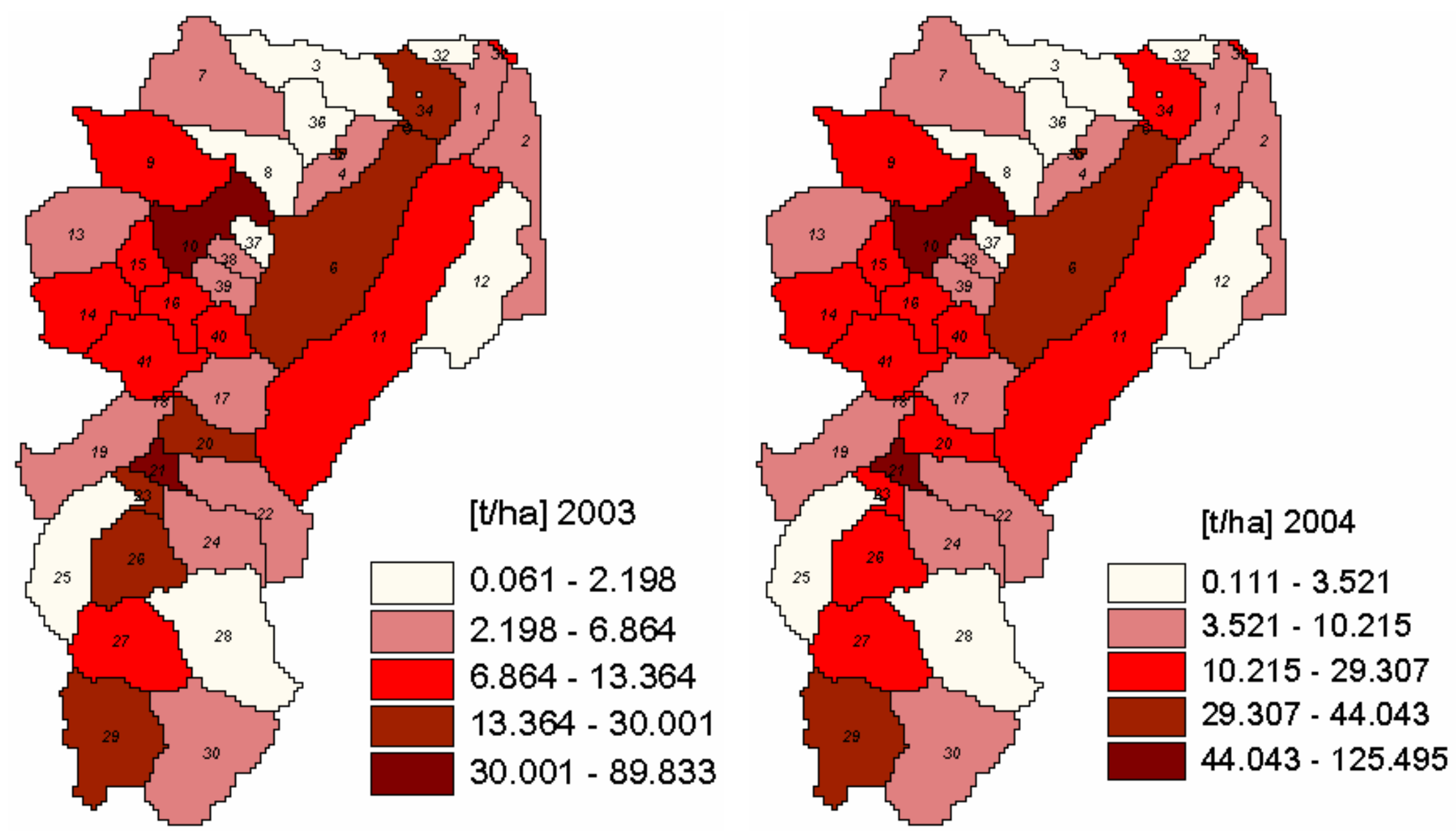

Figura 50. Distribuição espacial da produção anual de sedimentos (ton/ha) na MBHRB para os anos de 2003 e 2004. 

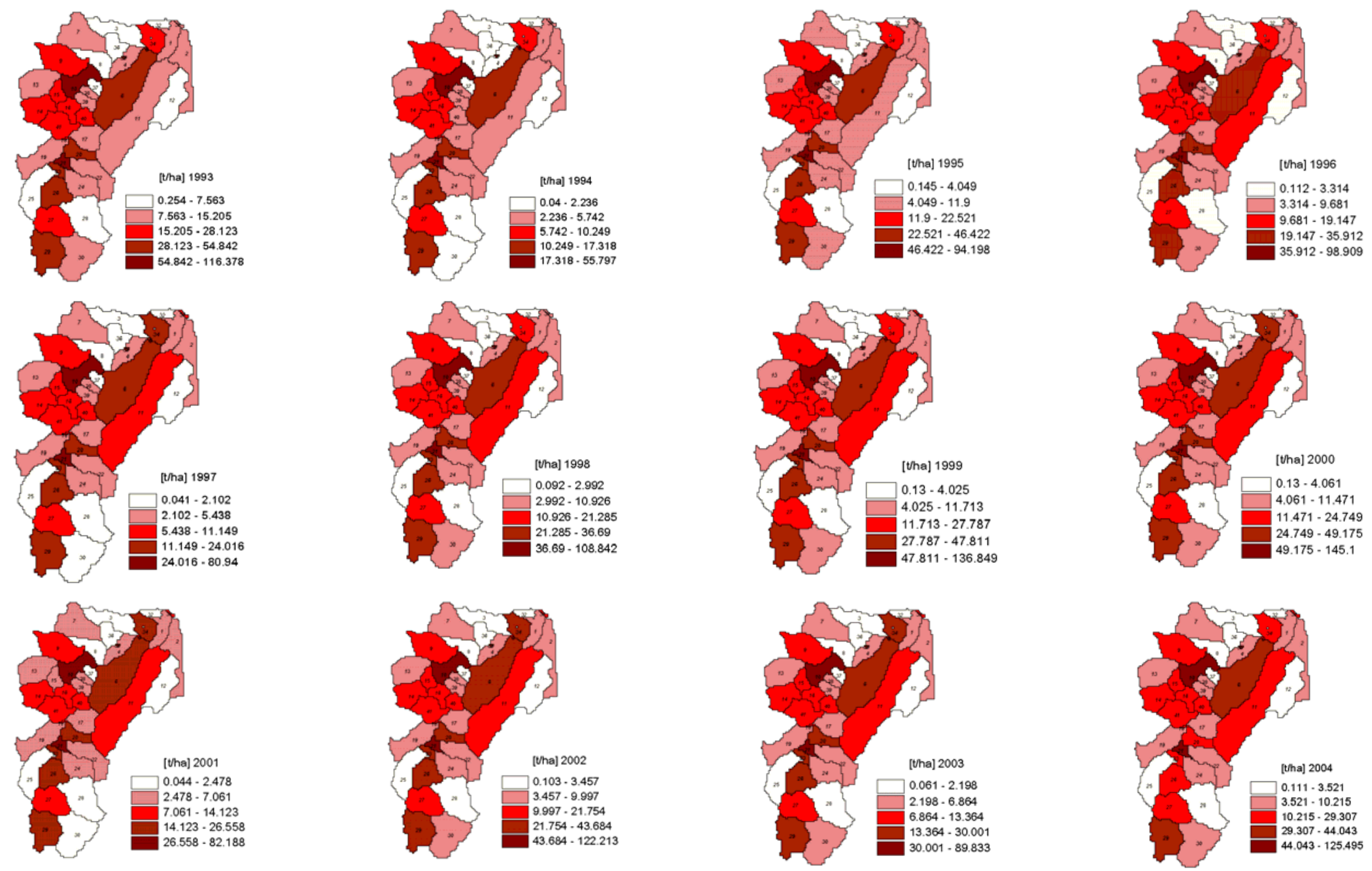

Figura 51. Distribuição espacial da produção anual de sedimentos (ton/ha) na MBHRB para os anos de 1993 a 2004. 
